\title{
INFLUÊNCIA DA QUALIDADE DA MADEIRA DE HÍBRIDOS DE Eucalyptus grandis x Eucalyptus urophylla E DO PROCESSO KRAFT DE POLPAÇÃO NA QUALIDADE DA POLPA BRANQUEADA
}

\section{Sheila Rodrigues dos Santos}

\author{
Dissertação apresentada à Escola Superior de \\ Agricultura "Luiz de Queiroz", Universidade de São \\ Paulo, para obtenção do título de Mestre em \\ Recursos Florestais, com opção em Tecnologia de \\ Produtos Florestais.
}

PIRACICABA

Estado de São Paulo - Brasil

Julho - 2005 


\title{
INFLUÊNCIA DA QUALIDADE DA MADEIRA DE HÍBRIDOS DE Eucalyptus grandis x Eucalyptus urophylla E DO PROCESSO KRAFT DE POLPAÇÃO NA QUALIDADE DA POLPA BRANQUEADA
}

\author{
Sheila Rodrigues dos Santos \\ Engenheiro Florestal
}

Orientador: Prof. Dr. CLÁUDIO ANGELI SANSíGOLO

\begin{abstract}
Dissertação apresentada à Escola Superior de Agricultura "Luiz de Queiroz", Universidade de São Paulo, para obtenção do título de Mestre em Recursos Florestais, com opção em Tecnologia de Produtos Florestais.
\end{abstract}

PIRACICABA

Estado de São Paulo - Brasil

Julho - 2005 
Dados Internacionais de Catalogação na Publicação (CIP) DIVISÃO DE BIBLIOTECA E DOCUMENTAÇÃO - ESALQ/USP

Santos, Sheila Rodrigues dos

Influência da qualidade da madeira de híbridos de Eucalyptus grandis x Eucalyptus urophylla e do processo Kraft de polpação na qualidade da polpa branqueada / Sheila Rodrigues dos Santos. - - Piracicaba, 2005.

$160 \mathrm{p}$.

Dissertação (Mestrado) - - Escola Superior de Agricultura Luiz de Queiroz, 2005. Bibliografia.

1. Branqueamento 2. Celulose de madeira 3. Celulose Kraft 4. Clone de eucalipto 5. Madeira 6. Polpa de madeira 7. Polpação 8. Química da madeira I. Título

CDD 634.9734

"Permitida a cópia total ou parcial deste documento, desde que citada a fonte - O autor" 


\section{DEDICATÓRIA}

Dedico este trabalho a Deus.

Obrigada, Senhor, por ter me escutado e socorrido nos momentos mais difíceis de minha caminhada. Pela luz que me tem iluminado, pelo tanto que me tem abrigado, pelo silêncio, pela graça e pela vida. 


\section{AGRADECIMENTOS}

A minha mãe pelo apoio, confiança e pelo amor; a você devo tudo que sou hoje.

Ao meu pai, que infelizmente não está mais fisicamente entre nós, mas que sinto sempre presente, dentro de mim, através do seu exemplo de dignidade e honestidade.

A minha irmã Carla pelo incentivo, pelos conselhos, por ouvir meus desabafos e pelo enorme carinho.

Aos meus irmãos Jefferson e Emerson pelo carinho.

Ao meu namorado Paulo pelo apoio, por me ouvir, dividir, pelas palavras, pelo seu amor. Ao professor Cláudio Angeli Sansígolo pela orientação constante, atenção, apoio e empenho.

A professora Sônia Maria Stefano Piedade pela ajuda nas análises estatísticas e atenção.

À Universidade de São Paulo, através da Escola Superior de Agricultura "Luiz de Queiroz”, pela oportunidade de realizar o curso de Pós-Graduação.

À Votorantim Celulose e Papel, através da Pesquisa e Desenvolvimento Florestal e da Pesquisa e Desenvolvimento de Celulose, pelo apoio financeiro concedido que permitiu a realização deste trabalho e por ceder o laboratório para a realização das análises.

Aos Engenheiros Fausto R. A. Camargo e Ricardo Toru Nishihata pelo incentivo a esse trabalho, e pela confiança no meu trabalho. 
A Vera Sacon pelo apoio, confiança e amizade.

Aos engenheiros Ana Gabriela, Celina e César pela colaboração e amizade.

Aos amigos da Votorantim Celulose e Papel/Unidade Luiz Antonio - Alessandra, Alexandre, Carolina, Denis, Juliana, Paula, Rogério, Sérgio, Tatiane, Valter e D. Zilda pela colaboração, amizade sincera e convivência agradável.

A todos que contribuíram, direta ou indiretamente, para a realização deste trabalho.

Muito obrigada. 


\section{SUMÁRIO}

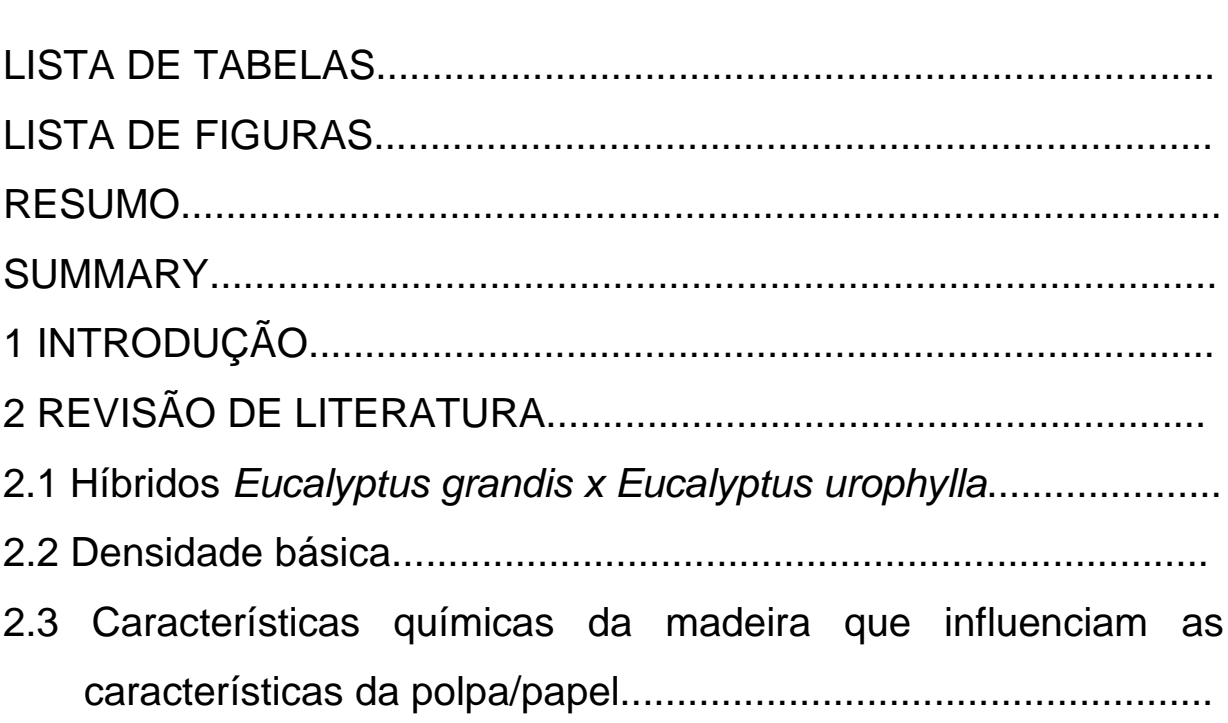

Página

viii

2.4 Características anatômicas ou morfológicas das fibras que influenciam as características da polpa.

2.4.1 Características anatômicas ou morfológicas das fibras da madeira.

2.4.2 Morfologia de fibras da polpa branqueada em analisador óptico automático

2.4.2.1 Comprimento da fibra.................................................... 16

2.4.2.2 Largura e Espessura da parede da fibra............................ 17

2.4.2.3 "Coarseness".................................................................... 18

2.4.2.4 Curvatura das fibras............................................... 19

2.5 Carga Alcalina .......................................................... 20

2.6 Branqueamento....................................................... 22 
Página

2.7 Refino.................................................................... 24

2.8 Propriedades dos produtos de celulose branqueada.................. 26

2.8.1 Papel "Tissue" .................................................................... 26

2.8.2 Papel de Imprimir e Escrever.......................................... 29

3 MATERIAL E MÉTODOS.................................................. 32

3.1 Material.................................................................. 32

3.2 Métodos................................................................. 32

3.2.1 Amostragem das árvores........................................... 32

3.2.2 Caracterização da madeira............................................... 33

3.2.3 Polpação Kraft da madeira.............................................. 34

3.2.4 Caracterização da polpa não-branqueada............................. 35

3.2.5 Caracterização do licor preto residual.................................. 36

3.2.6 Pré-deslignificação com $\mathrm{O}_{2}$ e branqueamento da polpa........... 36

3.2.7 Caracterização da polpa branqueada.................................. 38

3.2.7.1 Morfologia de fibras da polpa branqueada........................ 38

3.2.7.2 Refino da polpa branqueada..................................... 38

3.2.7.3 Propriedades físico-mecânicas da polpa branqueada em índice de tração constante e igual a 70 N.m/g..................... 39

3.2.7.4 Propriedades físico-mecânicas da polpa branqueada sem refino............................................................... 40

3.2.8 Análise estatística dos resultados.................................... 40

4 RESULTADOS E DISCUSSÃO........................................ 46

4.1 Qualidade da madeira..................................................... 46

4.2 Polpação Kraft........................................................... 48

4.3 Licor residual da polpação Kraft.......................................... 60

4.4 Branqueamento das polpas............................................. 72

4.5 Morfologia das fibras na polpa branqueada em Kajaani FS-200.. 86

4.6 Propriedades físico-mecânicas da polpa branqueada em índice de tração constante e igual a 70 N.m/g................................. 106 
Página

4.7 Propriedades físico-mecânicas da polpa branqueada sem refino 125

5 CONCLUSÕES .................................................................. 145

REFERÊNCIAS BIBLIOGRÁFICAS........................................ 150 


\section{LISTA DE TABELAS}

Página

1 Efeito das propriedades da madeira nas propriedades finais do papel produzido com polpa de fibra curta................................. 12

2 Características dos materiais genéticos ................................ 32

3 Metodologias utilizadas para a caracterização da madeira............ 34

4 Condições empregadas nas deslignificações Kraft........................ 35

5 Metodologias utilizadas para a avaliação do licor........................... $\quad 36$

6 Condições empregadas na pré-deslignificação com oxigênio e na seqüência de branqueamento................................................ 


\section{LISTA DE FIGURAS}

Página

1 Densidade básica e composição química dos clones G-31 e C-41. 47

2 Rendimento bruto da polpação Kraft............................................. 48

3 Rendimento depurado da polpa....................................... 50

4 Teor de rejeitos base madeira......................................... 52

5 Teor de rejeitos base celulose.......................................... 53

6 Número kappa da polpa................................................... 54

7 Viscosidade intrínseca da celulose........................................... 57

8 Consumo específico de madeira................................................ $\quad 59$

$9 \mathrm{pH}$ do licor residual das polpações Kraft....................................... 61

10 Teor de sólidos do licor residual das polpações Kraft................... 63

11 Densidade do licor residual das polpações Kraft......................... 64

12 Álcali ativo do licor residual das polpações Kraft........................ 65

13 Álcali efetivo do licor residual das polpações Kraft...................... 66

14 Álcali total do licor residual das polpações Kraft......................... 68

15 Álcali ativo consumido base madeira das polpações Kraft........... 69

16 Álcali ativo consumido base produto químico das polpações

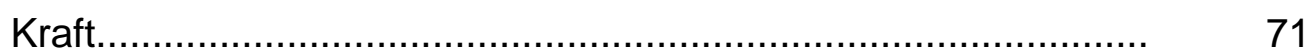

17 Eficiência na pré-deslignificação com oxigênio........................... 74

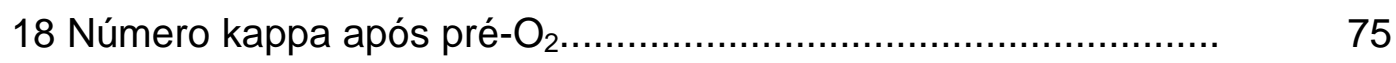

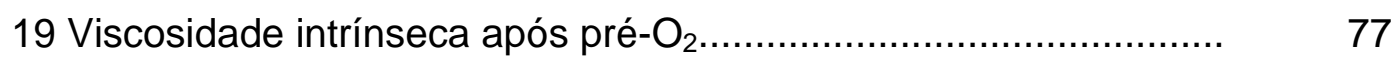

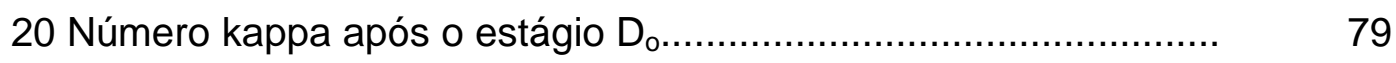

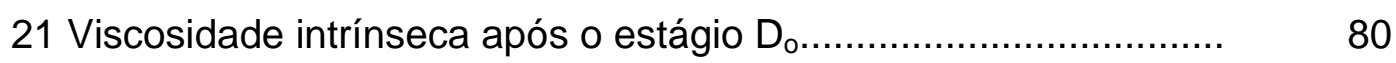


Página

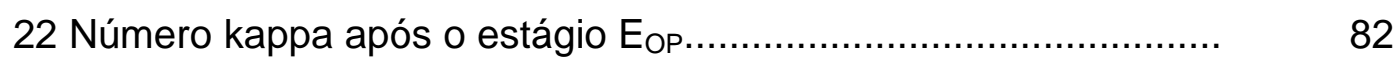

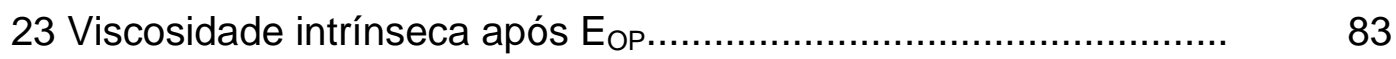

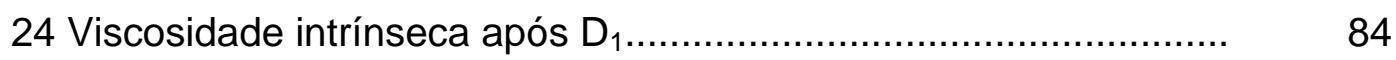

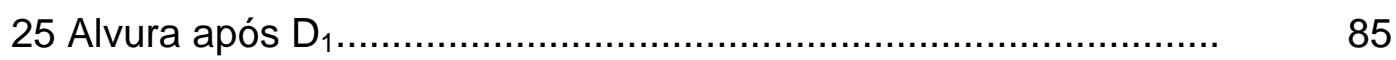

26 Comprimento médio ponderado da fibra................................ 88

27 Largura da fibra.......................................................... 89

28 Diâmetro do lume da fibra................................................ 91

29 Espessura da parede da fibra......................................... 92

30 Índice de enfeltramento da fibra........................................... 94

31 Coeficiente de flexibilidade da fibra..................................... 95

32 Fração parede da fibra....................................................... 96

33 Índice de Runkel da fibra................................................. 98

34 Índice de curvatura da fibra............................................... 100

35 "Coarseness" da fibra.............................................................. 101

36 População fibrosa............................................................... 103

37 Teor de finos menor que 0,1 mm (média aritmética)................... 104

38 Teor de finos menor que 0,2 mm (média aritmética).................. 105

39 Número de revoluções no PFI para índice de tração de 70 N.m/g 107

40 Grau Schopper Riegler para índice de tração de 70 N.m/g.......... 109

41 Volume específico aparente para índice de tração de 70 N.m/g... 110

42 Peso específico aparente para índice de tração de 70 N.m/g...... 112

43 Alongamento para índice de tração de 70 N.m/g....................... 113

44 Índice de energia absorvida na tração para índice de tração de

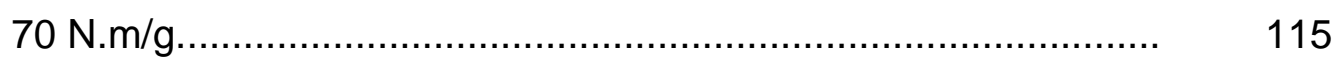

45 Índice de rigidez na tração para índice de tração de 70 N.m/g..... 116

46 Índice de arrebentamento para índice de tração de 70 N.m/g...... 117

47 Índice de rasgo para índice de tração de $70 \mathrm{~N} . \mathrm{m} / \mathrm{g}$..................... 118

48 Resistência ao ar para índice de tração de 70 N.m/g.................. 120

49 Índice de retenção de água para índice de tração de 70 N.m/g... 122 
Página

50 Ascensão capilar Klemm para índice de tração de 70 N.m/g....... 123

51 Opacidade para índice de tração de 70 N.m/g........................... 124

52 Grau Schopper Riegler de polpa sem refino............................. 126

53 Volume específico aparente da polpa sem refino...................... 128

54 Peso especifico aparente da polpa sem refino.......................... 129

55 Índice de tração da polpa sem refino..................................... 131

56 Alongamento da polpa sem refino........................................ 132

57 Índice de energia absorvida na tração da polpa sem refino.......... 133

58 Índice de rigidez na tração da polpa sem refino......................... 134

59 Índice de arrebentamento da polpa sem refino.......................... 136

60 Índice de rasgo da polpa sem refino...................................... 137

61 Resistência ao ar da polpa sem refino........................................ 138

62 Índice de retenção de água da polpa sem refino........................ 139

63 Ascensão capilar Klemm da polpa sem refino............................. 142

64 Opacidade da polpa sem refino............................................... 143 


\section{INFLUÊNCIA DA QUALIDADE DA MADEIRA DE HÍBRIDOS DE Eucalyptus grandis x Eucalyptus urophylla E DO PROCESSO KRAFT DE POLPAÇÃO NA QUALIDADE DA POLPA BRANQUEADA}

Autora: SHEILA RODRIGUES DOS SANTOS

Orientador: Prof. Dr. CLÁUDIO ANGELI SANSÍGOLO

\section{RESUMO}

O presente estudo analisou a influência de clones do híbrido de Eucalyptus grandis x Eucalyptus urophylla, com densidades básicas e cargas de álcali ativo diferentes, no processo de polpação e branqueamento. As características e propriedades das polpas não-branqueadas, licor preto residual, branqueamento, morfologia e propriedades físico-mecânicas das polpas branqueadas foram analisadas para avaliar os efeitos dos fatores clone e carga de álcali ativo. As polpações foram realizadas aplicando-se cargas de álcali ativo de $12,5 \%, 13,5 \%$ e $14,5 \%$. Em seguida, as polpas não-branqueadas foram submetidas a uma pré-deslignificação com oxigênio e branqueadas através da seqüência $D_{0} E_{O P} D_{1}$. As polpas branqueadas foram refinadas em moinho $P F I$ e analisadas quanto às resistências físico-mecânicas. Os resultados obtidos indicam que a madeira do clone G-31 apresentou menor densidade básica e teor de holocelulose, e maiores teores de extrativos totais e lignina Klason 
comparativamente à madeira do clone C-41. Os clones mostraram rendimentos bruto e depurado semelhantes. O clone G-31 produziu polpa com menor número kappa na menor carga alcalina e polpa com maior número kappa na maior carga alcalina revelando uma importante interação significativa clone $\mathrm{x}$ álcali ativo. Os fatores álcali ativo, clone e interação clone $x$ álcali ativo tiveram influências nos parâmetros avaliados na polpação. Os licores residuais dos clones apresentaram valores semelhantes de $\mathrm{pH}$, teor de sólidos solúveis, densidade e álcalis residuais. O clone G-31 consumiu mais álcali ativo residual. O fator que exerceu maior influência nestes parâmetros foi a carga de álcali ativo. 0 branqueamento mostrou para o clone G-31 maior eficiência na prédeslignificação com oxigênio e menor número kappa. A viscosidade intrínseca da celulose branqueada e a alvura foram mais elevadas para o clone C-41. O aumento da carga alcalina reduziu ligeiramente a alvura do clone G-31 e elevou a alvura do clone C-41. Os fatores álcali ativo, clone e interação clone $x$ álcali ativo tiveram influências nos parâmetros avaliados no branqueamento. A fibra da polpa branqueada do clone G-31 apresentou, significativamente, maiores comprimento, espessura da parede, índice de enfeltramento, fração parede e índice de Runkel; e menores diâmetro do lume, coeficiente de flexibilidade e "coarseness". O menor valor de "coarseness" mostrou fibras mais leves na polpa do clone G-31. O fator clone exerceu a maior influência nas propriedades físicas e mecânicas da polpa branqueada. A polpa branqueada do clone G-31 apresentou, significativamente, menor número de revoluções no moinho PFI para atingir o índice de tração de 70 N.m/g, baixo grau Schopper Riegler para atingir este nível de tração e gerou folhas com valores mais elevados de volume específico e opacidade. Estas características e propriedades permitiram concluir que a polpa do clone G-31 foi a mais atrativa e indicada para a fabricação de papéis de imprimir e escrever. A polpa branqueada do clone C-41 apresentou valores mais elevados de volume específico aparente e ascensão capilar Klemm quando analisadas sem refino. Estas propriedades foram mais evidentes nas 
cargas alcalinas mais elevadas. A polpa do clone C-41 mostrou características mais favoráveis para a fabricação de papéis para fins sanitários. 
WOOD QUALITY INFLUENCE OF Eucalyptus grandis X Eucalyptus urophylla HYBRIDS AND KRAFT PULPING PROCESS IN BLEACHED PULP QUALITY

Author: SHEILA RODRIGUES DOS SANTOS

Adviser: Prof. Dr. CLÁUDIO ANGELI SANSÍGOLO

\section{SUMMARY}

The present study has analyzed the influences of Eucalyptus grandis $\mathrm{x}$ Eucalyptus urophylla hybrid clones with different specific gravity and active alkali charges in the bleaching and pulping process. The characteristics and properties of unbleached pulp, residual black liquor, bleaching, bleached fiber morphology and bleached pulp physical-mechanical properties were analyzed to evaluate the effects of the active alkali charge and clone factors. The pulping were realized applying active alkali charges of $12,5 \%, 13,5 \%$ and $14,5 \%$. Then, the unbleached pulps were submitted to an oxygen delignification and bleached with the sequence $\mathrm{D}_{0} \mathrm{E}_{\mathrm{OP}} \mathrm{D}_{1}$. The bleached pulps were refined using $\mathrm{PFI}$ mill and the physical-mechanical properties were analyzed. The results showed that G-31 wood clone presented lower specific gravity and holocellulose content and higher total extractives and Klason lignin contents when compared to C-41 wood clone. Both of them showed similar pulp yield total and screening. The G-31 clone 
produced pulp with lower kappa number in the lowest alkaline charge and pulp with higher kappa number in the highest alkaline charge showing an important significant interaction between clone and active alkali. The factors active alkali, clone and clone $x$ active alkali interaction influenced in the evaluated parameters in the pulping. The clones residual black liquor showed similar values of $\mathrm{pH}$, soluble solids content, density and residual alkalis. The G-31 clone consumed more residual active alkali. The factor that exerted the highest influence in these parameters was the active alkali charge. The bleaching showed that the G-31 clone has higher efficiency in the oxygen delignification and lower kappa number. The bleached pulp viscosity and brightness were higher for C-41 clone. The increase in the alkaline charge reduced slightly the G-31 clone brightness and elevated the C-41 clone brightness. The factors active alkali, clone and clone $x$ active alkali interaction influenced in the bleaching parameters evaluated. The fiber of the G-31 bleached pulp showed, significantly, higher length, wall thickness, felting index, wall ratio and Runkel index, and lower lumen diameter, flexibility coefficient and coarseness. The lowest value of coarseness showed lighter fibers in the G-31 pulp. The factor clone exerted the highest influence in the physical and mechanical properties of the bleached pulp. The G-31 bleached pulp showed, significantly, lowest revolutions number in the PFI mill to reach tensile index of $70 \mathrm{~N} \cdot \mathrm{m} / \mathrm{g}$, low Schopper Riegler degree to reach this tensile index and generated sheets with higher values to bulk and opacity. These characteristics and properties allow to conclude that G-31 pulp was the most attractive and indicated to produce printing and writing papers. The bleached pulp of C-41 clone showed higher values of bulk and capillarity Klemm when analyzed without refining. These properties were more evident in the highest alkaline charges. The C-41 pulp showed characteristics more favorable to the production of tissue papers. 


\section{INTRODUÇÃO}

O Brasil é o maior produtor mundial de polpa Kraft branqueada de Eucalyptus e detentor de elevado nível científico-tecnológico em plantações florestais deste gênero. É conhecido, que fibras de eucalipto possuem características peculiares que contribuem, de forma favorável, na qualidade de determinados tipos de papéis, tais como os de imprimir e escrever e "tissue".

A competição entre os produtores de celulose e papel para oferecer um produto de qualidade diferenciada a um preço competitivo, a fim de não só aumentar, mas também manter sua participação no mercado, é cada vez maior. Por esta razão, o setor de celulose e papel tem procurado produzir polpas que possibilitem atingir as características desejadas ao produto final. Com o objetivo de alcançar melhorias qualitativas e quantitativas, adequação ambiental, redução de custos de produção e demandas mercadológicas, estudos dedicados ao melhoramento do eucalipto ganharam importância. Hoje, depois de décadas de pesquisa, os resultados são realmente satisfatórios. A condução de florestas clonais tem apresentado resultados favoráveis no que diz respeito à uniformidade da matéria-prima, às características silviculturais e também às características tecnológicas, tais como: densidade básica, teor de lignina, rendimento em celulose, teor de extrativos e características da polpa. São utilizadas técnicas que permitem uma manipulação do material genético de forma a contribuir, em maior ou menor proporção, com a fixação de parâmetros que hoje são comprovadamente conhecidos pelo seu favorecimento na melhoria da qualidade de determinados tipos de papéis. 
As diversas espécies de árvores e as variáveis envolvidas em seu crescimento, assim como as condições de polpação, branqueamento e refinação exercem forte influência nas propriedades finais do papel quanto às características químicas, ópticas e mecânicas.

Sendo assim, o presente trabalho teve o objetivo de estudar as influências da madeira de clones de híbridos de Eucalyptus grandis x Eucalyptus urophylla com densidades básica e carga de álcali ativo diferentes no processo de polpação Kraft e branqueamento. As características e propriedades da polpa não branqueada, licor preto residual, branqueamento, polpa branqueada, morfologia de fibras branqueadas e propriedades físico-mecânicas da polpa branqueada foram analisadas para avaliar os efeitos dos fatores clone e álcali ativo. 


\section{REVISÃO DE LITERATURA}

\subsection{Híbridos Eucalyptus grandis x Eucalyptus urophylla}

O eucalipto é a árvore mais plantada no mundo, com mais de 17,8 milhões de hectares. O Brasil é o segundo maior país em área plantada, com cerca de três milhões de hectares, ultrapassado apenas pela Índia (FAO, 2000). As primeiras iniciativas de clonagem do eucalipto datam de meados do século passado. Em 1950, Bouvier, engenheiro florestal francês, descobriu, casualmente, a possibilidade de propagação de materiais juvenis de eucalipto por estaquia. A heterogeneidade dos plantios e a incidência de cancro (Cryphonectria cubensis), na década de 70, foram decisivas para 0 desenvolvimento da técnica de clonagem no Brasil, considerada hoje como referência mundial no controle de doenças do eucalipto (Alfenas et al., 2004).

O melhoramento de plantas consiste basicamente em modificar seu patrimônio genético, com a finalidade de obter variedades, ou híbridos, capazes de apresentar maior rendimento possível, com produtos de alta qualidade e capazes de se adaptar às condições de um determinado ambiente, além de exibirem resistência às pragas e doenças. Desse modo, a variabilidade genética existente na população de melhoramento é a matéria-prima sobre a qual são realizados processos de seleção e recombinação. Em linhas gerais, o método clássico de melhoramento de plantas baseia-se no cruzamento entre duas variedades, de maneira a promover uma recombinação de caracteres (hibridação), com a finalidade de aumentar a variabilidade gênica. Nas gerações seguintes, faz-se uma seleção dos indivíduos portadores de caracteres 
desejáveis. A seleção repetida ao longo de várias gerações, leva a população vegetal para a direção que deseja. Após o melhoramento de espécies, é possível então efetuar a clonagem.

O processo de transformação genética está se tornando uma prática mais rotineira com várias espécies. Transformação genética e outras técnicas de genética molecular podem ser adaptadas para modificar a expressão de genes existentes, como por exemplo, para aumentar ou diminuir a atividade de genes que estão por trás das características de interesse. Muito progresso tem sido feito sobre clonagem, mapeamento genético, seleção de marcador assistido e transformação genética. Ainda assim, lacunas no entendimento da genética, fisiologia e bioquímica da árvore continuam a limitar o progresso (Dinus \& Welt, 1997).

A susceptibilidade ao cancro do eucalipto, aliada a baixa capacidade de rebrota em climas sujeitos a deficiências hídricas, limitaram a utilização extensiva do E. grandis. Como conseqüência, a síntese do híbrido $E$. grandis $x$ E. urophylla, passou a ser a base da silvicultura intensiva clonal brasileira (Ruy, 1998).

Segundo Busnardo (1981) o Eucalyptus urophylla e seus híbridos (como o Eucalyptus grandis x Eucalyptus urophylla) constituem uma das principais fontes de matéria-prima para a indústria brasileira de celulose, apresentam excelente desenvolvimento em altura e em diâmetro e densidade básica intermediária entre as de média densidade básica $\left(0,460 \mathrm{~g} / \mathrm{cm}^{3}-E\right.$. grandis e $E$. saligna) e as de alta densidade (acima de $0,570 \mathrm{~g} / \mathrm{cm}^{3}-$ E. citriodora e $E$. paniculata).

Oda \& Ferreira (1982) observaram que, aos 14 meses, o híbrido de $E$. grandis x E. urophylla plantados no Estado de São Paulo, apresentou uma superioridade em relação ao $E$ grandis, tendo ainda maior retidão de fuste e melhores características de ramificação.

No Brasil, as espécies E.grandis e E. urophylla e o seu híbrido adquiriram grande importância para a produção de papel e celulose de fibra curta. Martins 
\& Ikemori, citados por Carvalho (2000), estudando vários cruzamentos entre espécies de eucalipto, destacam que o Eucalyptus grandis x Eucalyptus urophylla foi o híbrido que mais se destacou, devido suas características desejáveis para a produção de celulose, sua boa produtividade relacionada a adaptação ecológica às condições do local e mostrando inclusive resistência ao cancro.

Os programas de melhoramento florestal que utilizam a hibridação são bastante aplicados em empresas do setor que dispõem hoje de milhares de hectares plantados com indivíduos clonados de híbridos. Segundo Ikemori \& Campinhos Jr. (1983) e Bertolucci et al. (1993), nestes plantios o híbrido de Eucalyptus grandis $x$ Eucalyptus urophylla destaca-se por apresentar alta produtividade no campo, e excelentes características de qualidade da fibra.

\subsection{Densidade básica da madeira}

Entre os diferentes tipos de densidade da madeira, a densidade básica é a que permite estabelecer mais claramente os critérios de comparação, por determinar a massa de madeira anidra ou seca em estufa contida em unidade de volume verde ou saturada, ambas condições muito estáveis na madeira. (Kollman, 1959).

$\mathrm{Na}$ condução de uma nova floresta, é importante entender os efeitos da densidade da madeira e das propriedades das fibras nas propriedades da polpa. É preciso conhecer se um aumento na densidade da madeira apenas gera mais material lenhoso por metro cúbico ou se há relação entre madeira, fibra e propriedades do papel. Tal relação será útil tanto na avaliação dos efeitos das práticas de manejo nas propriedades e qualidade dos produtos finais como para predizer as propriedades da polpa de florestas melhoradas (Hatton \& Cook, 1992).

Dinus \& Welt (1997) relataram que a densidade básica da madeira é um parâmetro muito importante na produção de papel, pois contribui para a 
resistência do mesmo. Embora seja geralmente considerada como uma característica única, a densidade básica é um componente dependente das proporções de lenho inicial e tardio, do tamanho e número de fibras e da espessura da parede da fibra. Em madeiras de coníferas, a proporção de lenho tardio e a espessura da parede do lenho tardio exercem forte influência na densidade básica. Em madeiras de folhosas, a densidade básica é influenciada por estes fatores e pela proporção e tamanho dos elementos de vasos e outros tipos de células. Segundo os autores, a alta densidade básica em Pinus taeda é devido à alta proporção de lenho tardio com fibras de paredes espessas. Entretanto, a alta densidade básica em híbridos de Eucalyptus pode ser devido a um elevado número de fibras com lume estreito e paredes celulares relativamente finas e flexíveis.

A densidade básica é reconhecida unanimemente na literatura como uma característica hereditária e como uma das principais características da madeira. É de fácil determinação e é um teste de baixo custo. A densidade básica também influencia o rendimento volumétrico no digestor. No entanto, a alta densidade básica pode causar alguns problemas como tornar a penetração do licor na madeira mais difícil e, conseqüentemente, mais rejeitos podem ser gerados (Valente et al. 1992). Os autores ainda relatam que a uniformidade da densidade básica é uma característica importante a ser considerada na tecnologia de polpação. Quando a densidade aumenta, a estrutura do papel torna-se mais porosa e a resistência à tração é reduzida. Madeiras densas têm fibras com paredes espessas e diâmetro do lume pequeno, conseqüentemente, são mais rígidas e tem baixas propriedades de colapsabilidade durante 0 processamento. A polpa tem rápida drenagem e produz uma estrutura volumosa e, em conseqüência, um papel com alta porosidade e opacidade. Fibras com paredes mais espessas também demandam maior consumo de energia no refino. Ao mesmo tempo, a ligação interfibras é fraca, dando baixa resistência ao papel. 
Vasconcelos Dias \& Cláudio-da-Silva Jr. (1985) verificaram que quimicamente, as árvores com madeiras mais densas apresentaram uma elevação no teor de lignina e uma diminuição no teor de hemiceluloses, em relação a madeiras de menores densidades, para o eucalipto de mesma espécie. O aumento da espessura da parede celular e o decréscimo do diâmetro da fibra demonstraram acompanhar o aumento da densidade básica da madeira. Por outro lado, o comprimento médio de fibras e o teor de extrativos na madeira não se mostraram correlacionados com a densidade básica. Concluíram que o rendimento da polpação aumenta quando a densidade básica varia de 418 a aproximadamente $470 \mathrm{~kg} / \mathrm{m}^{3}$, mas decresce continuamente deste ponto até densidades de $666 \mathrm{~kg} / \mathrm{m}^{3}$, acompanhado de um constante aumento no teor de rejeitos. Apesar disto, uma projeção obtida para o rendimento do digestor demonstrou um crescente aumento da capacidade de produção com o uso de madeiras mais densas. A viscosidade e o teor de sólidos apresentaram valores significativamente mais altos quando obtidos a partir da polpação de madeiras mais densas, com conseqüentes sobrecargas no sistema de recuperação, o que poderia limitar a capacidade de produção de polpa. Verificaram também que as propriedades do papel branqueado mostraram-se altamente correlacionadas às variações na densidade básica. O peso específico aparente do papel e a resistência à tração sofreram um decréscimo significativo com o aumento da densidade da madeira, enquanto a resistência ao rasgo é negativamente afetada pelo aumento da densidade a baixos e médios níveis de refino, e não se correlaciona a altos níveis. A porosidade do papel e a opacidade (a médios e altos níveis de refino) demonstraram aumentar com um acréscimo na densidade básica. Com o aumento da densidade básica da madeira a flexibilidade das fibras é reduzida, e a conformidade da estrutura do papel é dificultada. Conseqüentemente a presença de espaços vazios em maior quantidade afeta diretamente o peso específico aparente, porosidade e opacidade do papel. Para o índice de rasgo observaram valores decrescentes com o aumento da densidade da madeira. 
Foelkel et al. (1992) verificaram que havia uma tendência de diminuição dos extrativos da madeira em diclorometano com o aumento da densidade e que os valores de solubilidade da madeira em $\mathrm{NaOH} 8 \%$ decresciam com 0 aumento da densidade devido a madeiras mais densas apresentarem menor teor de carboidratos de cadeia curta, o que é compreensível, pois deve aumentar a proporção de parede celular tipo S2, mais rica em celulose. Verificaram também que madeiras com densidades mais uniformes possuem melhor comportamento tecnológico, dando melhores propriedades nas polpas. Algumas propriedades importantes da polpa do eucalipto, na verdade algumas das principais propriedades na comercialização desse tipo de polpa, como volume específico, resistência ao ar e absorção de água, mostrou ser muito mais dependente da densidade da madeira do que da espécie.

Estudos de Kibblewhite, citado por Duffy \& Kibblewhite (1989), tem mostrado que para Pinus radiata da Nova Zelândia, a densidade básica é o primeiro indicador de qualidade da polpa Kraft e propriedades do papel. Obtiveram correlação direta entre densidade e propriedades da polpa e certas propriedades de resistência do papel. O autor mostrou que entre 70 a $90 \%$ das variações nos índices de rasgo e estouro e na densidade aparente da folha podem ser explicados pelas variações na densidade básica.

De acordo com Demuner et al. (1991) existem evidências de que madeiras com maior densidade básica tem fibras menos flexíveis, devido aos elevados valores de momento de inércia da secção transversal das fibras, em conseqüência da maior espessura de parede. A um mesmo nível de refino, fibras com tais características são mais resistentes à ação de forças de consolidação durante a formação da folha de papel, resultando em papel menos resistente, com estrutura mais aberta, com maior volume específico aparente, porosidade, opacidade e aspereza (rugosidade) da superfície. 


\subsection{Características químicas da madeira que influenciam as características da polpa/papel}

Para a determinação da qualidade das madeiras de eucalipto, visando a produção de polpa e papel os parâmetros químicos como os teores de celulose, lignina, pentosanas e extrativos tem sido considerados os mais relevantes e normalmente são relacionados com os aspectos quantitativos de rendimento e consumo de produtos químicos durante os processos de deslignificação (Carvalho et al. 1998 e Wallis et al., 1996b).

A polpação química é baseada no princípio de que a lignina pode ser degradada seletivamente usando químicos apropriados permitindo a separação das fibras sem destruir a celulose ou a forma das fibras (Bamber, 1985).

Mesmo quando a composição química da madeira é conhecida, é difícil prever, com precisão, o seu comportamento durante a polpação uma vez que os componentes encontram-se arranjados de forma complexa tornando o comportamento diferente de quando estão isolados. De qualquer forma, o conhecimento da composição química da madeira em seus componentes principais como celulose, lignina e extrativos é importante para interpretar o comportamento da madeira no processo de polpação, assim como para determinar a qualidade da polpa produzida. Segundo Valente et al. (1992), um baixo teor de lignina e um alto teor de carboidratos requererão condições menos severas de polpação e conduzirão a um alto rendimento gravimétrico.

Cohen \& Mackney, citados por Wallis et al. (1996a), estabeleceram correlações significativas entre propriedades químicas da madeira e propriedades da polpa. Lignina e extrativos apresentaram correlação negativa com rendimento em polpação Kraft, enquanto que para frações de carboidratos, a $\alpha$-celulose correlaciona-se positivamente com rendimento em polpa. A holocelulose (celulose mais hemiceluloses) geralmente correlaciona-se fraca e positivamente com o rendimento em polpa. Os autores relataram que duPlooy 
encontrou uma boa correlação entre rendimento e teor de celulose para $E$. grandis.

Trabalhos mostraram que o rendimento da polpa Kraft de folhosas correlacionam-se positivamente com o teor de celulose da madeira e mais fracamente com o teor de hemiceluloses. Para madeira de Eucalyptus, o rendimento em polpa Kraft é, na maioria das vezes, fortemente correlacionado com o teor de celulose e fraca e negativamente com o teor de hemiceluloses (Wright \& Wallis, 1998).

A composição química da madeira desempenha um papel econômico no processo de produção de polpa. Madeiras com maiores teores de lignina podem exigir um maior consumo de álcali durante a polpação, gerando, conseqüentemente, maiores teores de sólidos para queima na caldeira (Santos, 2000).

Segundo Wagberg \& Annergren (1997) mesmo a celulose sendo o componente da polpa que confere resistência às fibras, polpas com altos teores de celulose e baixos teores de hemiceluloses desenvolvem menores resistências quando são refinadas. Uma explicação para esse fato pode ser um aumento da despolimerização da celulose ou a uma quantidade mínima de hemiceluloses que proporcione uma distribuição adequada das tensões nas paredes das fibras (Wagberg \& Annergren, 1997 e Spiegelberg, 1966).

A principal hemiceluloses presente nas madeiras de eucalipto é a xilana. As hemiceluloses são muito hidrofílicas e são as maiores responsáveis pela habilidade da fibra em absorver água, facilitando o inchamento das fibras, promovendo a lubrificação interna, aumentando a flexibilidade das fibras e a área de contato entre as fibras proporcionando ligações interfibras mais fortes. Tais fatos implicam em fibras mais conformáveis com estruturas mais coesas e que demandam menor energia de refino para atingir as mesmas propriedades necessárias (Warberg \& Annergren, 1997, Laine \& Hynynen, 1997 e Barzyc et al. 1997). Entretanto, a maior retenção de água diminui a drenabilidade do papel o que pode comprometer o andamento das máquinas de papel, que 
normalmente já estão operando em suas máximas capacidades de drenagem. Dessa forma, uma correta refinação dependerá do balanço entre as forças mecânicas e o comportamento intrínseco das fibras (Ferreira et al. 1998).

As hemiceluloses, além de afetarem o rendimento na produção de polpa, desempenham importante função no processamento e nas propriedades da polpa e também do papel (Britt citado por Almeida et al., 2000), pois podem afetar importantes interações químicas entre as fibras, a água e outros produtos químicos que são agregados para a formação do papel.

Os extrativos presentes na madeira são normalmente removidos durante o processamento químico. Assim, altos teores de extrativos conduzem a baixos rendimentos em polpa. As quantidades de extrativos que permanecem na polpa são muito pequenas e seus efeitos na qualidade da polpa são insignificantes. Entretanto, certos extrativos causam a redução da alvura de polpas branqueadas.

De acordo com Jordão \& Mangolini (1998), os extrativos exercem efeito marcante sobre as propriedades de absorção da polpa, pois esses compostos podem formar um rearranjo estrutural na superfície da fibra à medida que o tempo de estocagem aumenta, podendo assim influenciar a taxa de absorção de água dos papéis para fins sanitários.

$\mathrm{Na}$ indústria de celulose e papel, o "pitch" é definido por compostos orgânicos provenientes da resina da madeira, associados a materiais inorgânicos e fibras. Os problemas causados pelo "pitch" são indesejáveis, pois esta resina adere em filtros lavadores, tanques de armazenamento e linhas de transporte, além disso, pode diminuir a qualidade do produto final quando permanece na polpa. 


\subsection{Características anatômicas ou morfológicas das fibras que influenciam as características da polpa/papel}

\subsubsection{Características anatômicas ou morfológicas das fibras da madeira}

Os três principais fatores que controlam a resistência do papel são: densidade da fibra (espessura de parede celular e porcentagem de madeira juvenil), comprimento de fibra e resistência da fibra (Dinwoodie 1965).

Os parâmetros anatômicos, como porcentagem e dimensão de fibras, vasos e parênquima, além de número de fibras por grama e "coarseness", são os mais utilizados na avaliação da qualidade da madeira de eucalipto para produção de celulose e papel e estão relacionados com a qualidade da polpa e associados às propriedades físico-mecânicas e características superficiais e ópticas do papel produzido (Carvalho et al. 1998).

Paavilainen (1998) publicou um resumo sobre as relações de dependência existentes entre a madeira e o papel interligados com as propriedades das fibras que compõem a folha de papel, o qual está expresso na tabela 1.

Tabela 1. Efeito das propriedades da madeira nas propriedades finais do papel produzido com polpa de fibra curta

\begin{tabular}{|c|c|c|}
\hline Propriedades da madeira & $\begin{array}{l}\text { Propriedades da } \\
\text { fibra }\end{array}$ & Propriedades do papel \\
\hline $\begin{array}{l}\text { Diâmetro da fibra / } \\
\text { Espessura da parede }\end{array}$ & Rigidez & $\begin{array}{c}\text { "Bulk" } \\
\text { Rigidez }\end{array}$ \\
\hline Comprimento da fibra & $N^{\circ}$ fibras / grama & $\begin{array}{c}\text { Dispersão de luz, Opacidade, } \\
\text { Formação, Porosidade }\end{array}$ \\
\hline $\begin{array}{l}\text { "Coarseness" } \\
\text { Teor de hemiceluloses }\end{array}$ & $N^{\circ}$ fibras / grama & $\begin{array}{l}\text { Dispersão de luz, Opacidade } \\
\text { Estabilidade dimensional }\end{array}$ \\
\hline
\end{tabular}

O comprimento da fibra afeta algumas propriedades do papel, em particular, resistência ao rasgo e resistência a dobras. Papéis feitos de fibras de eucalipto podem ser inferiores nessas propriedades. Contudo, a resistência ao 
rasgo de polpas de folhosas pode ser aumentada adequadamente pela incorporação de fibra de alguma conífera (fibra longa). O comprimento da fibra de madeira de eucalipto é, contudo, satisfatória para muitos papéis (Bamber, 1985).

De acordo com Ferreira \& Mendes de Souza (s. d.) as fibras mais curtas tem menor tendência para flocular e por isso geram uma melhor formação da folha e lisura superficial. Além disto, a apertada distribuição dos comprimentos das fibras favorece a produção de papel com uma distribuição mais homogênea do tamanho dos poros, beneficiando a absorção de tinta e, assim, a impressão. Relatam também que fibras mais rígidas darão origem a folhas de papel mais abertas e com maior volume específico aparente. A maior facilidade de drenagem destas fibras influencia positivamente a velocidade da máquina de papel, devido ao maior teor de secura no fim da rede de fibras beneficiando a resistência a úmido.

Amidon (1981) comenta que o comprimento e a espessura da parede da fibra são os parâmetros mais importantes das fibras e exercem influência sobre o coeficiente de flexibilidade, sobre a fração parede e sobre o índice de Runkel. Alguns trabalhos citados pelo autor relatam que o comprimento da fibra não é independente da flexibilidade da fibra e que o comprimento da fibra é considerado uma variável chave apenas para resistência ao rasgo.

Outra característica muito importante para as propriedades do papel é a largura da fibra. Fibras mais largas produzirão papéis com menor resistência ao ar, maior volume específico aparente e maior resistência ao rasgo. Por outro lado, prejudicarão a formação da folha uma vez que tem maior tendência a flocular na caixa de entrada. No entanto, neste caso, poderá ser observada uma maior facilidade de drenagem, influenciando positivamente a velocidade da máquina de papel devido ao maior teor seco obtido. As resistências à tração e ao arrebentamento são prejudicadas quando as fibras são mais largas, devido ao ajuste imperfeito das fibras no papel, prejudicando as ligações entre fibras. 
A espessura da parede é uma característica anatômica tão importante quanto a largura da fibra e geralmente está relacionada com a rigidez da fibra. Carvalho et al. (1998) relatam que fibras com maiores espessuras de parede podem sofrer maior desfibrilamento durante o processo de refinação, o que aumenta o potencial de ligações interfibrilares, aumentando a área de ligação entre as fibras e, conseqüentemente, a resistência à tração do papel. Segundo os autores, fibras com maiores espessuras de parede sofrem maior efeito de hidratação e inchamento, aumentando ainda mais seu volume, gerando maior área para ligações e, desta forma, proporcionando condições para maiores resistências.

De acordo com Demuner et al. (1991) fibras com parede mais espessa produzem papéis com estrutura mais aberta, com maiores valores de volume específico aparente, de opacidade e de aspereza superficial, a um mesmo nível de refino. Essas características têm efeito significativo sobre as propriedades de resistência do papel, principalmente aquelas que dependem fundamentalmente do número e da resistência das ligações entre as fibras.

O índice de enfeltramento é a relação entre o comprimento e a largura da fibra. Alguns autores verificaram que esta relação não tem efeito apreciável nas propriedades do papel. Entretanto, segundo Artuz-Siegel et al., citado por Gonçalez (1986), a resistência ao rasgo parece estar relacionada com o índice de enfeltramento, havendo um aumento nessa propriedade com o aumento desse índice.

A fração parede é a relação porcentual entre a espessura da parede celular e a metade da largura da fibra. Em geral admite-se que quando a fração parede é maior que $40 \%$, as fibras serão extremamente rígidas, pouco flexíveis e haverá dificuldades na interligação das mesmas. Esta relação mantém maior proporcionalidade com resistência ao rasgo e menor com tração, ao arrebentamento e peso específico aparente (Foelkel \& Barrichelo, 1975).

Segundo Silva Jr. et al. (1996), fibras com fração parede elevada tendem a dar origem a papéis com volume específico aparente alto, pois quando estas 
fibras são comprimidas durante a formação do papel, seu grau de colapso é menor do que os das fibras com frações parede baixas, que apresentam alto grau de colapso tendendo a formarem fitas. Valores altos de fração parede indicam fibras rígidas, pouco flexíveis e com pequeno potencial de ligação (Gonçalez et al. 1986).

O coeficiente de flexibilidade é expresso pela relação entre o diâmetro do lume e a largura da fibra, em porcentagem. A flexibilidade da fibra influencia o número de ligações interfibras porque fibras mais flexíveis proporcionam maior contato interfibras. Em geral, um aumento no número de ligações resulta em aumento nas propriedades de resistência, embora sob certas condições. Um exemplo seria que em uma folha de alta densidade possa ser encontrada uma redução na resistência ao rasgo com o aumento no número de ligações (Dinwoodie, Helle, Kellogg e Tamolang citados por Amidon, 1981).

O coeficiente de flexibilidade possibilita avaliar a capacidade de flexão da fibra e o potencial de ligação interfibras, correlacionando-se, diretamente, com as resistências à tração e ao arrebentamento (Gonçalez et al. 1986).

O índice de Runkel é a razão entre duas vezes a espessura da parede celular e o diâmetro do lume. Runkel observou que as fibras de madeira, com o índice por ele desenvolvido menor que 1,0, produziam polpas de boa qualidade, com boa capacidade de interligação. Quando este índice era maior que 1,0 as madeiras não eram satisfatórias para a produção de polpa de boa qualidade. Inúmeras pesquisas mostraram que este índice guarda o mesmo tipo de relação com a qualidade da polpa que a espessura da parede celular e a fração parede.

Segundo Ferreira \& Mendes de Souza (s. d.) o Índice de Runkel, auxilia a avaliação da aptidão das fibras para o processamento (velocidade da máquina de papel, operações de acabamento do papel) e propriedades finais do papel ("bulk" e rigidez). O índice de Runkel apresenta relação inversa com a resistência à tração e ao arrebentamento, segundo Rydhlom citado por Gonçalez et al. (1986). 


\subsubsection{Morfologia de fibras da polpa branqueada em analisador óptico automático}

As dimensões das fibras se alteram quando determinadas na madeira e na polpa branqueada devido a três fatores (Levlin \& Söderhjem, 1999). Primeiro, a madeira é reduzida a cavacos e esta operação pode cortar fibras se não for efetuada de forma correta. Segundo, as condições de polpação e branqueamento alteram as dimensões das fibras. Durante estes processos, lignina e hemiceluloses são solubilizadas da parede celular e tornam as fibras mais finas e mais flexíveis. Terceiro, as fibras durante o processamento da polpa sofrem tratamentos mecânicos em misturadores, desintegradores, bombeamentos e espessadores, os quais deformam a fibra e induzem curvatura gradual e contínua ("curl") e curvatura torcida ("kink") que tem influência no comprimento da fibra.

Trepanier (1998) relata que o comprimento e a forma da fibra se alteram durante a polpação e branqueamento. Estas alterações podem afetar fortemente a qualidade e o desempenho do produto.

Braaten \& Molteberg (2004) relatam que a seção transversal da fibra pode deformar ou colapsar durante polpação, significando desvios das verdadeiras dimensões das fibras.

\subsubsection{Comprimento da fibra}

Há vários métodos ópticos para medir o comprimento da fibra. O princípio primário é obter uma suspensão de fibras para poder fluir através de uma cubeta. A fonte de luz ilumina o fluxo para detectar as fibras com uma câmara. A técnica de análise de imagem aumenta a resolução dos valores das dimensões das fibras. O método óptico é descrito na norma TAPPI T 271 pm-98.

Hoje, o Kajaani FS-200 é o analisador óptico automático mais usual para medir as dimensões de fibras. Ele mede a distribuição do comprimento da fibra, 
o comprimento médio da fibra e o "coarseness" de uma amostra de polpa obtida com alta precisão (Levlin \& Söderhjem, 1999).

Segundo Carvalho et al. (1997) o Kajaani FS-200 foi projetado especificamente para medir a distribuição do comprimento de fibras da polpa celulósica. As medidas são baseadas na habilidade dessas fibras alterarem a direção da luz polarizada. O FS-200 é usado extensivamente na indústria de celulose e papel porque é muito rápido (ele pode medir 20.000 fibras em aproximadamente 10 minutos) e simples de usar.

O comprimento médio das fibras pode ser expresso de três formas conforme mostrado a seguir. O comprimento médio ponderado por comprimento é o mais utilizado porque se relaciona melhor com as propriedades do papel e não é tão dependente da proporção de finos (Carvalho et. al.,1997).

$$
\begin{aligned}
& \text { Média aritmética, Média ponderada por Média ponderada por } \\
& \text { Ln comprimento, LIw peso, Lww } \\
& \operatorname{Ln}=\frac{\sum_{i=1}^{n} n i . L i}{\sum_{i=1}^{n} n i} \quad \operatorname{LIw}=\frac{\sum_{i=1}^{n} n i . L i^{2}}{\sum_{i=1}^{n} n i . L i} \quad L W w=\frac{\sum_{i=1}^{n} w i . L i}{\sum_{i=1}^{n} w i}
\end{aligned}
$$

Onde: $\mathrm{ni}=$ número de fibras na classe $\mathrm{i} ; \mathrm{Li}=$ comprimento médio na classe $\mathrm{i} ;$ wi $=$ peso de fibras na classe $\mathrm{i}$

O princípio é detectar o início e o final da fibra e calcular o comprimento com estas informações e velocidade de fluxo.

\subsubsection{Largura e Espessura da parede da fibra}

Hoje, os analisadores da qualidade da fibra medem o comprimento da fibra na polpa de forma muito rápida. A largura e a espessura da parede também podem ser determinadas, mas somente os analisadores de custo elevado têm esta capacidade. A precisão destas medidas pode ser questionada, 
desde que há possibilidade da seção transversal deformar ou colapsar durante polpação, significando desvio das verdadeiras dimensões da fibra (Braaten \& Molteberg, 2004). Estes autores propõem um método matemático para determinar a espessura da parede celular e largura da fibra na polpa baseado no "coarseness" da fibra, rendimento da polpação e densidade da madeira.

\subsubsection{3 "Coarseness"}

A "coarseness" é definida como peso por unidade de comprimento da fibra, expressada como miligramas por $100 \mathrm{~m}$ (ou decigramas por $10 \mathrm{~km}$ ). É uma propriedade importante das fibras para fazer papel. A "coarseness" afeta as respostas das fibras na fabricação do papel e altera várias propriedades de estrutura, resistência e óptica do produto.

Segundo Foelkel ${ }^{1}$ o alto valor de "coarseness" (fibras pesadas) implica em alto rasgo, alto volume específico aparente, alta porosidade, fraca folha úmida, baixa opacidade, alta rapidez para absorver água, drenagem rápida, superfície rugosa, baixa população fibrosa e ligação interfibras prejudicada. O baixo valor de "coarseness" (fibras leves) implica em alta tração e arrebentamento, baixo volume específico aparente, baixa porosidade, folha úmida resistente, alta opacidade, alta colapsabilidade, alta retenção de água, drenagem lenta, superfície lisa, alta população fibrosa e ligação interfibras favorecida.

Segundo Kerekes \& Schell (1995), a "coarseness" exerce sua influência na uniformidade da folha através do número de contatos por fibras, tamanho dos flocos e mobilidade das fibras durante a formação.

\footnotetext{
${ }^{1}$ FOELKEL, C. E. B. Palestra fibras e polpas. ${ }^{\circ}$ Celsius Degree / Grau Celsius. Disponível em: www.celsofoelkel.com.br
} 
Cotterill \& Macrae (1997) estudando quatro espécies de Eucalyptus verificaram que a maior "coarseness" é normalmente associada com a rigidez absoluta das fibras, que requer mais refino para colapsar e gerar polpas com razoáveis níveis de resistência à tração.

A determinação correta da "coarseness" das fibras sempre tem sido um desafio. O método comum é a medida do comprimento projetado total de uma massa de polpa conhecida usando um analisador de comprimento de fibra óptico como um Kajaani FS-100 ou FS-200. A "coarseness" resulta da divisão da massa de polpa pelo comprimento total das fibras. Na prática, a equação seguinte é utilizada para o cálculo da "coarseness" (Seth \& Chan, 1997).

$C=\frac{m}{n \cdot L}$

Onde: $\mathrm{C}=$ "coarseness"; $\mathrm{m}=$ massa pequena de fibras s.e. introduzida no analisador; $L=$ comprimento médio aritmético das fibras e $n=$ número total de fibras na massa $\mathrm{m}$.

\subsubsection{Curvatura das fibras}

A curvatura da fibra é o desvio da linha reta em relação ao eixo da fibra. As fibras na madeira são retas. Entretanto, as fibras se curvam durante a polpação, processamento da polpa e refino (Robertson et al., 1999).

Há duas maneiras usuais de avaliar a forma da fibra (Trepanier, 1998). O índice de curvatura da fibra ("curl index"), definido como uma curvatura gradual e contínua da fibra, é determinado através da seguinte expressão:

$$
I C=\left(\frac{L}{I}\right)-1
$$


Onde: $I C$ = índice de curvatura da fibra; I = comprimento de contorno da fibra (maior comprimento) e $\mathrm{L}=$ comprimento projetado (menor comprimento).

O índice de curvatura torcida das fibras ("kink index") é a soma ponderada das curvaturas $\mathrm{N}$ com determinados intervalos de ângulos, conforme mostrado a seguir:

$\mathrm{IK}=\frac{\left(2 \mathrm{~N}_{21-45}+3 \mathrm{~N}_{46-90}+4 \mathrm{~N}_{90-180}\right)}{\mathrm{L}_{\text {total }}}$

Onde: $\mathrm{IK}=$ índice de kink da fibra; $\mathrm{N}=$ número de curvaturas $\mathrm{e} \mathrm{L}_{\text {total }}=$ comprimento projetado total.

\subsection{Carga alcalina}

Segundo a literatura, Fardim \& Duran (2004), os químicos como $\mathrm{NaOH}$ e $\mathrm{Na}_{2} \mathrm{~S}$ são empregados no licor de polpação para separar as fibras a altas temperaturas, conduzindo a diferentes graus de degradação da lignina e carboidratos. As hemiceluloses são mais suscetíveis a hidrólises alcalinas que a celulose devido a seu baixo grau de polimerização, estado amorfo e acessibilidade ao licor de polpação. O álcali ativo é a variável da polpação que mais afeta a retenção de xilanas, ácidos urônicos, lignina e a degradação macromolecular da celulose em polpação Kraft de Eucalyptus. O uso de baixos níveis de álcali ativo na polpação melhora todas as propriedades mecânicas da polpa, mas reduz a alvura e aumenta o número kappa.

O aumento da carga alcalina na polpação proporciona redução significativa do rendimento gravimétrico do processo de polpação. Tal fato acontece, no caso de madeiras de folhosas, devido à degradação das xilanas, as quais são sensíveis ao aumento da carga alcalina, prejudicando a seletividade da polpação (Ek et al., 2001). 
De acordo com Gomide (1979) os carboidratos, tanto a celulose como as hemiceluloses, podem ser muito instáveis, em soluções alcalinas. Durante a polpação alcalina, ocorrem quebras hidrolíticas das ligações glucosídicas, causando a separação dos grupos ou cadeias laterais e a quebra das cadeias principais dos carboidratos. Essas reações de degradação resultam na formação de compostos solúveis de baixas massas moleculares e, conseqüentemente, num decréscimo do rendimento.

Em estudo de híbridos de E. grandis x E. urophylla com idades variando de 1 a 7 anos onde se aplicou diferentes níveis de álcali ativo, Alencar (2002) verificou que a medida que aumenta o nível de álcali tem-se um aumento no grau de deslignificação e, conseqüentemente, a redução do número kappa, do rendimento depurado, do teor de rejeitos e o aumento da seletividade da polpação.

Em estudo com madeiras de Eucalyptus globulus, Axelsson et al. (2000), verificaram que o rendimento para um dado número kappa é diminuído substancialmente pelo aumento da temperatura ou carga de álcali na polpação. Um aumento nestas variáveis também resulta no decréscimo da viscosidade.

Collins et al. (1990) mencionam que madeiras com alto teor de lignina são freqüentemente difíceis de deslignificar, necessitando de altas cargas de álcali e longos tempos de reação. Segundo os autores, geralmente o rendimento é menor para polpação com alta carga alcalina. Uma possível explicação para este efeito é que os polissacarídeos sofrem grande dissolução em licores com alta concentração de álcali. Os ácidos formados na dissolução de polissacarídeos são os maiores consumidores de álcali durante a polpação soda de spruce.

Kubes et al. citados por Almeida (2003) estudando o efeito do álcali efetivo aplicado na polpação Kraft convencional e Kraft-AQ em madeira de spruce sobre a viscosidade da polpa não branqueada constataram que o aumento da carga de álcali efetivo influencia de maneira expressiva a 
viscosidade da polpa, estando esse comportamento de acordo com estudos conduzidos anteriormente.

Axelsson et al. (s.n.t.) e Pascoal Neto et al. (2003) relatam em seus trabalhos que a branqueabilidade se eleva com o aumento da carga alcalina. Assim a alta concentração de ânions $\mathrm{OH}^{-}$e $\mathrm{HS}^{-}$no licor de polpação é muito benéfico para a resposta da polpa Kraft ao branqueamento. Entretanto, a melhora da branqueabilidade com o álcali ativo é acompanhada por um decréscimo significativo do rendimento e da viscosidade de polpas nãobranqueadas, o que é refletido no rendimento e nas propriedades mecânicas de polpas branqueadas.

Segundo Gengo et al. (1990) um aumento da carga de álcali aplicada em polpação Kraft diminui a retenção de hemiceluloses nas fibras e o rendimento do processo. Também como resultado da carga alcalina, a polpa foi mais difícil de refinar. O comprimento máximo de auto-ruptura e o índice de arrebentamento diminuíram, enquanto o rasgo, em um certo comprimento de auto-ruptura, aumentou.

Os resultados obtidos por Almeida et al. (2000), de um estudo de híbridos de Eucalyptus grandis W. Hill ex Maiden x Eucalyptus urophylla S. T. Blake, mostraram que a carga alcalina aplicada exerceu considerável efeito na taxa de deslignificação, principalmente nas etapas de impregnação e concorrente.

\subsection{Branqueamento}

O controle do processo numa fábrica de celulose é, às vezes, dificultado pela necessidade de modificação das condições de polpação causada pela heterogeneidade do suprimento de madeira. As condições de polpação e a qualidade da madeira afetam substancialmente o rendimento, a qualidade e a branqueabilidade da polpa. Apesar de vários estudos comprovarem o efeito das variáveis da polpação no produto final, o conhecimento detalhado das ações de cada variável não é bem conhecido, principalmente para madeira de eucalipto. 
Tem sido demonstrado que as condições de polpação podem afetar a natureza química da lignina residual, o teor de lignina lixiviável, a constituição química dos carboidratos, os compostos lignina-carboidratos e o teor de ácidos hexenurônicos presentes nas polpas Kraft de folhosas. Essas características são provavelmente os fatores responsáveis pela branqueabilidade e estabilidade de alvura da polpa, mas os seus graus de importância não são bem conhecidos para polpas Kraft de eucalipto (Gomide et al. 2000).

A deslignificação com oxigênio, introduzido comercialmente nos anos setenta, atualmente, é considerada uma tecnologia bem estabelecida e importante na produção de polpas ECF e TCF, com redução do impacto ambiental e com baixo custo operacional (McDonough citado por Silva, 1996). O estágio de deslignificação com oxigênio combina uma fase de deslignificação propriamente dita com outra de alvejamento da polpa. Entretanto, o mecanismo de reações do oxigênio com a polpa é complexo.

Silva (1997) concluiu que a eficiência da deslignificação com oxigênio mostrou-se maior para as polpas de madeira de mais difícil deslignificação e que a dificuldade de deslignificação da madeira causa um efeito negativo na polpa branqueada, isto é, à medida que se utiliza madeira de mais difícil deslignificação haverá como conseqüência produtos de polpas branqueadas (ECF e TCF) com menores viscosidades, embora tal fato não necessariamente reflita nas resistências físico-mecânicas da polpa. Concluiu também que existe efeito na qualidade da polpa, com relação ao comportamento diferenciado de madeiras na polpação, causados por variações da qualidade de madeira, sobre as propriedades físico-mecânicas e ópticas.

O uso do dióxido de cloro em substituição ao cloro molecular está bastante difundido nas indústrias de celulose que utilizam seqüências de branqueamento convencional ECF (Elemental Chlorine Free). Isto se deve ao fato do dióxido de cloro ser um agente de branqueamento muito eficiente e versátil, podendo ser utilizado em diferentes etapas na seqüência de branqueamento, além, de sua aplicação resultar processos mais seletivos. Na 
primeira etapa do branqueamento, o dióxido de cloro pode atuar como um agente deslignificante $\left(D_{0}\right)$. Nas etapas subseqüentes do branqueamento, pode atuar como um agente alvejante $\left(D_{1}\right.$ e $\left.D_{2}\right)$ (Oliveira, 2004).

O peróxido de hidrogênio remove a lignina parcialmente e transforma os grupos cromóforos em grupos carboxílicos incolores tendo, desta forma, as funções de deslignificação e alvejamento. Em geral, o peróxido possui caráter mais alvejante, sendo colocado numa posição mais estratégica na sequência de branqueamento, mais especificamente ao final da sequência (Oliveira, 2004).

\subsection{Refino}

A refinação é um tratamento mecânico, efetuado sobre a polpa, com fibras completamente separadas e que tem por fim efetuar mudanças na estrutura das fibras que compõem a polpa. As características físicas que são dadas às fibras durante o processo de refinação, vão resultar em certas propriedades do papel acabado (Ito, 1977).

A energia requerida na refinação para polpas é um dos maiores custos na produção de papel e é uma informação muito importante para os fabricantes de papel, não apenas em termos de custo de produção, mas também porque o aumento do refino leva a um decréscimo de propriedades como a opacidade, a porosidade e volume específico aparente (Cotterill \& Macrae, 1997).

Bamber (1985) relata que as fibras da polpa não estão necessariamente na forma adequada para a fabricação do papel. Para fazer papéis mais resistentes, as fibras devem ser flexíveis o suficiente para assegurar que elas entrem em contato e colapsem para formar uma superfície achatada e também rica em celulose assegurando ligação adequada. Isto é normalmente assegurado pelo refino que envolve deformações vigorosas da fibra na presença de água. Durante este processo a parede incha permitindo que a molécula de água penetre entre as moléculas cristalinas de celulose. 
As características químicas e anatômicas das polpas influenciam suas tendências de floculação e, conseqüentemente, suas respostas ao refino (Demuner et al., 1990).

A facilidade de refino é uma importante vantagem industrial, pois favorece a economia de energia. Os resultados obtidos por Gonçalez et al. (1986) mostraram que o refino favoreceu o desenvolvimento da resistência ao rasgo e o aumento do peso específico aparente do papel. Ferreira et al. (1998) também verificou que com a refinação, as polpas aumentam as suas resistências bem como a capacidade de retenção de água (Grau Schopper Riegler), em resultado dos fenômenos de fibrilação interna e externa, de formação de finos e de aumento de flexibilidade, que ocorrem nesta fase. Simultaneamente, a maior área de ligação entre as fibras mais conformáveis reduz a interface material fibroso/ar, o que faz diminuir o coeficiente de dispersão de luz.

A refinabilidade das polpas, isto é, a facilidade com que são refinadas e a variação que as suas propriedades sofrem durante a refinação, é função da estrutura e da constituição das fibras (Ferreira \& Figueiredo, 2001). Segundo os autores, a refinação reduz o comprimento das fibras e introduz também modificações na sua secção transversal, verificando-se um aumento da espessura da parede para o interior da fibra, a medida em que a largura desta não aumenta, e a área do lume se reduz substancialmente. Finalmente, a refinabilidade de polpas é também condicionada de modo relevante pelas condições de polpação, sendo menores os ganhos com a refinação para as polpas com fibras de parede mais espessa e estrutura menos flexível.

Com a refinação observa-se um aumento geral das resistências mecânicas, da resistência ao ar e da densidade das folhas, e uma diminuição do coeficiente específico de dispersão de luz (Astals, 1988, Brindley, 1996, Clark, 1985, Dillner \& Jonsson, 1979 e Paavilainen, 1993). 


\subsection{Propriedades dos produtos de celulose branqueada}

\subsubsection{Papel "Tissue"}

O termo tissue é utilizado para descrever produtos de baixa gramatura, freqüentemente crepado, como papel higiênico, toalha de cozinha, guardanapo de mesa, guardanapo de sanitário e lenço de papel.

Os principais parâmetros de qualidade dos papéis tissue são os seguintes: gramatura, absorvência, maciez, espessura, volume específico aparente, resistência à tração, alvura/brancura, alongamento/crepe e aparência (Paulapuro, 2000).

Segundo Foelkel ${ }^{2}$, as propriedades desejadas para papéis tissue são: maciez, suavidade ao tato, absorção, sensação de papel fofo e volumoso, resistência, baixo teor de finos, dentre outras. Para isso, são necessárias fibras rígidas e com baixo grau de colapsabilidade para resistir a gofragem e crepagem, fibras estreitas, baixo teor de hemiceluloses e relativa resistência ao refino, baixo teor de células de parênquima, baixa ligação entre fibras, mantendo uma rede frouxa e porosa.

A gramatura do papel tissue depende do uso final e pode variar de 12 a $50 \mathrm{~g} / \mathrm{m}^{2}$. As baixas gramaturas são utilizadas em produtos multicamadas onde a maciez é importante (tissue facial e papel higiênico de qualidade superior). As gramaturas mais elevadas são usadas em produtos de camada única onde capacidade de secura e resistência são fundamentais (toalha de mesa e guardanapos de mesa e sanitário).

\footnotetext{
${ }^{2}$ FOELKEL, C. E. B. Qualidade da Madeira de eucalipto para atendimento das exigências do mercado de celulose e papel. ${ }^{\circ}$ Celsius Degree / Grau Celsius. Disponível em: www.celso-foelkel.com.br
} 
A absorvência é normalmente avaliada usando água. As propriedades que devem ser determinadas são capacidade de absorção e velocidade de absorção, as quais são importantes em produtos como toalhas e guardanapos. A capacidade de absorção reflete quanta água o papel tissue pode absorver ( $\mathrm{g}$ de água/g de papel). A velocidade de absorção mede a rapidez que o produto pode absorver água. A unidade é s/cm de papel e em certos produtos, o liquido utilizado pode ser o óleo.

A maciez é considerada como a propriedade do papel tissue mais apreciada pelos consumidores. Entretanto, é uma propriedade muito subjetiva e não há métodos normalizados para sua avaliação. Cada indústria tem seu próprio método, e as diferenças são efetuadas por comparação. Um dos métodos é o de apalpar com as mãos o papel tissue e classificar a maciez numa escala de 2 a 6 . Um papel higiênico de qualidade superior tem nesta escala o valor 6 , enquanto que um tissue de fibras recicladas tem um valor 2 .

A maciez do papel tissue depende da espessura, volume específico aparente e flexibilidade do papel. A maciez é muito importante nos papéis higiênicos e tissue facial. Segundo Liu \& Hsieh (2004), é crença comum que a sensação de maciez é influenciada pela superfície e pelo corpo, ou volume específico ("bulk"), do papel. Em pesquisas precedentes, propriedades do tissue como corpo ou espessura, compressibilidade, módulo de elasticidade, e textura da superfície, têm sido correlacionadas com a sensação de maciez. Normalmente, uma folha mais encorpada aparenta maior maciez, enquanto as demais propriedades permanecem inalteradas. A compressibilidade (relação entre volumes aparentes do papel medido sob menores e maiores pressões) é uma indicação da expansibilidade do tissue. É normalmente admitido que a rigidez do tissue se relaciona inversamente com seu grau de maciez.

A espessura e volume específico aparente são propriedades importantes nos papéis tissue. A compactação da rede de fibras e a ligação entre fibras são indesejáveis na estrutura do tissue. O volume específico tem influência, também, 
quando se produz o papel tissue embalado. Por exemplo, um rolo de tolha de cozinha deve ter determinado diâmetro e certos números de folhas.

A resistência à tração é importante para evitar quebras da folha durante o processo de produção do papel tissue. Entretanto, diminui a maciez e o volume específico aparente. Ratnieks \& Foelkel (1996) descrevem que os papéis para fins sanitários devem apresentar valores de resistência à tração suficiente apenas para proporcionar a resistência úmida da folha durante o processo de fabricação.

A alvura e a brancura devem ser elevadas nos papéis tissue feitos com polpa química branqueada. A aparência é outra propriedade importante nos papéis tissue. É importante observar o número de folhas e diâmetro do rolo, corte das folhas, gravuras em relevo, cor e qualidade da impressão no papel.

A taxa de crepe reflete o quanto o papel tissue encurta durante a crepagem e varia de 10 a 30\%. A crepagem é efetuada para ajustar a espessura e o alongamento, os quais tem efeito considerável na maciez e absorção.

As hemiceluloses são benéficas ao desenvolvimento da refinação, portanto a remoção controlada das mesmas, obtida normalmente por meio de cargas mais elevadas de álcali durante o processo de polpação, pode ser empregado quando se deseja obter polpa específica para a produção de papéis tissue. Tal condição de processo também diminui o "coarseness" e aumenta, por conseqüência, o número de fibras por grama. Ratnieks \& Foelkel (1996) mostraram a existência de correlação positiva entre o teor de hemiceluloses e a resistência à tração em polpas sem refino, uma vez que as ligações interfibras dependem muito mais das hemiceluloses depositadas na superfície das fibras que da própria capacidade de colapsamento intrínseco das fibras. 


\subsubsection{Papel de Imprimir e Escrever}

Os papéis de imprimir e escrever são destinados a atender os processos de impressão para reprodução de livros, cadernos, documentos, propagandas e desenho.

Casals (s.d.) classifica as propriedades que estão relacionadas à impressão e escrita em três grupos:

1. propriedades intrínsecas do papel: cor, brancura, alvura, brilho, opacidade, porosidade (permeância ao ar), lisura (aspereza), gramatura, peso específico aparente, dureza, compressibilidade, uniformidade de espessura, estabilidade dimensional, colagem e estrutura interna (formação),

2. propriedades que influem diretamente na impressão: umidade absoluta e relativa, absorvência, acidez ou alcalinidade, direção de fibra (direcionalidade), limpeza superficial, planicidade, esquadrado, resistência à formação de bolhas, resistência à tração, resistência a úmido, resistência ao rasgo e resistência ao arrancamento superficial,

3. propriedades que influem no produto impresso: dobras duplas, resistência ao alongamento, resistência ao arrebentamento, resistência à abrasão, resistência ao deslizamento, rigidez à flexão, resistência à água, permeabilidade ao vapor d' água, permeabilidade às graxas e resistência à luz e calor.

De acordo com Foelkel $^{3}$ as principais propriedades requisitadas pelos papéis de impressão e escrita são: lisura, opacidade, formação (arranjo fibroso da folha de papel), volume específico ("bulk"), porosidade, imprimabilidade, resistência, estabilidade dimensional, dentre outras. Essas propriedades podem ser obtidas com numerosas fibras curtas e estreitas, com relativa rigidez e boa refinabilidade, capazes de se manter unidas sem colapsar, constituindo uma rede bem estruturada, com boa ligação entre fibras e baixo teor de elementos de vaso.

${ }_{3}^{3}$ FOELKEL, C. E. B. Qualidade da Madeira de eucalipto para atendimento das exigências do mercado de celulose e papel. ${ }^{\circ}$ Celsius Degree / Grau Celsius. Disponível em: www.celso-foelkel.com.br 
A madeira de eucalipto, graças as suas propriedades morfológicas, tem fornecido ao segmento de papéis de imprimir e escrever fibras com propriedades adequadas, o que permite a produção de papéis com 100\% de fibras de eucalipto branqueadas com excelente qualidade. Entretanto, embora a madeira de eucalipto apresente essas vantagens, é necessário viabilizar a produção de florestas específicas e adequar o processo de produção da polpa celulósica (Barbosa, 2001).

De acordo com Foelkel (1998) a polpa com alto número de fibras por grama e baixo "coarseness" são propriedades requisitadas pelos papéis de imprimir e escrever e podem proporcionar maior valor de opacidade, melhor formação e maior "bulk" da folha de papel. Para que a resistência da folha de papel possa ser mantida, as fibras empregadas na produção desses papéis devem apresentar alta habilidade de ligação interfibras e alto coeficiente de flexibilidade. O poder de ligação das fibras é favorecido pela presença das hemiceluloses. Segundo o autor, madeiras de eucalipto com menor densidade básica apresenta geralmente os requisitos desejados por este tipo de papel.

A formação e a lisura são propriedades sensivelmente melhoradas por madeiras de menor densidade básica, tendo em vista as propriedades morfológicas geralmente associadas a esse tipo de madeira. A resistência ao rasgo e à tração, a porosidade e a opacidade são as principais propriedades a serem avaliadas na polpa destinada à produção de papéis de imprimir e escrever, sendo essas propriedades um indicativo da habilidade de ligação das fibras e da resistência intrínseca da fibra. O maior teor de finos, desde que não em níveis elevados, ajuda também a aumentar a opacidade das folhas, porém é importante um cuidado especial no processo de refinação, para evitar que a fibra seja cortada e colapsada em excesso.

A porosidade do papel é influenciada pelo tamanho dos espaços vazios presentes na superfície da folha, sendo a mesma governada pela composição química da fibra e pelas características morfológicas (dimensões, estrutura da parede, grau de resistência ao colapsamento e de ligação interfibras), estando 
esses parâmetros muito relacionados com o teor de hemiceluloses presentes na superfície das fibras. Papéis de imprimir e escrever necessitam de folhas com estrutura mais fechada, porém papéis com estrutura muito fechada podem ter a sua estabilidade dimensional comprometida (Ratnieks \& Foelkel, 1996). 


\section{MATERIAL E MÉTODOS}

\subsection{Material}

Os materiais utilizados foram árvores de um clone de baixa densidade básica (G-31) e árvores de outro clone de densidade básica mais elevada (C41), plantadas na região de Itapetininga/SP. A Tabela 2 mostra as características dos clones utilizados no presente estudo.

Tabela 2. Características dos materiais genéticos

\begin{tabular}{lcc}
\hline Parâmetro & \multicolumn{2}{c}{ Material Genético } \\
& $\begin{array}{c}\text { Clone G-31 } \\
\text { C densidade básica }\end{array}$ & > densidade básica \\
\hline Espécie & E. grandis x E. urophylla & E. grandis x E. urophylla \\
Idade & 6,5 anos & 6 anos \\
IMA $^{*}(5,5$ anos $), \mathrm{m}^{3} /$ ha/ano & 47 & 38 \\
Solo & LV1 & LVA2 \\
\hline
\end{tabular}

*Incremento Médio Anual

\subsection{Métodos}

\subsubsection{Amostragem das árvores}

A amostragem consistiu na colheita de 12 árvores com DAP médio para cada material genético. Cada árvore foi abatida e seccionada em toretes de 0,5 m de comprimento na base, 20, 40, 60, 80 e 100\% da altura comercial e 
transformada em cavacos por meio de um picador modelo Demuth. Os cavacos correspondentes a cada árvore foram individualmente identificados e armazenados em sacos de polietileno.

Os cavacos de cada árvore foram analisados em relação à densidade básica e teor absolutamente de secos. Após a obtenção desses resultados, realizou-se para cada clone individualmente, um sorteio para a formação de 3 amostras, sendo cada amostra composta por 4 árvores. Portanto, para cada clone obteve-se 3 amostras compostas, as quais foram consideradas as repetições do experimento.

Para a confecção de cada uma das amostras compostas, pesou-se o equivalente a $7 \mathrm{~kg}$ absolutamente secos de cavacos de cada árvore, homogeneizou-se muito bem e, em seguida, a amostra composta foi armazenada em sacos de polietileno. Posteriormente, determinou-se o teor absolutamente de secos da amostra composta e também foi realizada outra análise de densidade básica.

As análises químicas foram realizadas em uma parte de cada amostra composta obtida por quarteamento. Os cavacos obtidos desta forma foram moídos em moinho tipo Wiley e a serragem obtida foi classificada para a obtenção da fração 40/60 mesh. As análises químicas foram realizadas em triplicata.

\subsubsection{Caracterização da madeira}

A Tabela 3 mostra as metodologias utilizadas para a caracterização das amostras compostas de cavacos de cada clone. 
Tabela 3. Metodologias utilizadas para a caracterização da madeira

\begin{tabular}{lll}
\hline Ensaio & \multicolumn{1}{c}{ Norma } \\
\hline $\begin{array}{l}\text { Preparação da madeira para análises } \\
\text { químicas }\end{array}$ & TAPPI T 264 cm-97 \\
Densidade Básica & Método do Máximo Teor de \\
Extrativos totais & Umidade - Foelkel et al., 1971 \\
Lignina Klason & ABTCP m 3/69 \\
Holocelulose $(\mathrm{H})$ & TAPPI T 249 cm-85 \\
& H=100 - (\% Lignina + \% Extrativos \\
\end{tabular}

\subsubsection{Polpação Kraft da madeira}

Os cavacos foram classificados antes da polpação Kraft. Cada amostra composta de cavacos passou em classificador dotado de movimento vibratório e provido de 5 peneiras com orifícios com diâmetro de 1 1/8" (28,56 mm), 7/8" (22,23 mm), 5/8" (15,88 mm), 3/8" (9,53 mm) e 3/16" (4,76 mm). As frações de cavacos retidas na peneira com orifícios de 1 1/8" $(28,56 \mathrm{~mm})$ e as que ultrapassaram a peneira com orifícios de 3/16" (4,76 $\mathrm{mm}$ ) foram desprezadas grossos e finos, respectivamente. As frações selecionadas foram secas ao ar e armazenadas em sacos de polietileno para uniformização e conservação da umidade.

As polpações Kraft foram efetuadas em três níveis de álcali ativo para cada amostra composta por clone visando avaliar o efeito desta variável nas características e propriedades da polpa não-branqueada, no licor residual, no branqueamento, na morfologia de fibras e na polpa final branqueada. As polpações foram efetuadas em duplicata. Portanto, a polpação Kraft foi realizada em 36 amostras compostas de cavacos (2 clones $\times 3$ amostras compostas de madeira/clone x 3 níveis de álcali ativo na polpação/clone $\times 2$ repetições da polpação).

As deslignificações Kraft foram realizadas em digestor de circulação forçada, modelo M\&K - 609, com dois reatores individuais de 6,7 litros de 
capacidade. Em cada polpação foi utilizado o equivalente a $800 \mathrm{~g}$ de cavacos secos.

A tabela 4 mostra as condições empregadas nas deslignificações das amostras compostas de cavacos de cada clone estudado.

Tabela 4. Condições empregadas nas deslignificações Kraft

\begin{tabular}{ll}
\hline Parâmetro & Condição \\
\hline Álcali Ativo, \% como $\mathrm{Na}_{2} \mathrm{O}$ & 12,$5 ; 13,5$ e 14,5 \\
Sulfidez, \% & 25 \\
Temperatura, ${ }^{\circ} \mathrm{C}$ & 166 \\
Tempo de subida, h & 1 \\
Tempo à temperatura, h & 2 \\
Relação licor/madeira, L/Kg seco em estufa & $4 / 1$ \\
\hline
\end{tabular}

\subsubsection{Caracterização da polpa não-branqueada}

Os cavacos de madeira, após as deslignificações, foram muito bem lavados com água em excesso. A polpa foi desintegrada e a separação dos rejeitos da polpa foi efetuada em depurador marca Noriam com fenda de 0,2 $\mathrm{mm}$. Após depuração de toda polpa bruta, os rejeitos foram coletados na superfície da tela e secos em estufa a $105 \pm 3{ }^{\circ} \mathrm{C}$. Posteriormente a estas etapas procedeu-se à determinação do teor de rejeitos, rendimento bruto e rendimento depurado.

A determinação do número kappa e viscosidade da celulose foram efetuadas na polpa depurada obtida de cada polpação. O método utilizado para avaliar o número kappa foi a norma TAPPI T $236 \mathrm{~cm}-85$ e para a viscosidade intrínseca da celulose a norma SCAN C 15:62 ou manual Viscomat BMT - 8. 


\subsubsection{Caracterização do licor preto residual}

A Tabela 5 mostra as metodologias utilizadas para a caracterização dos licores pretos residuais de cada deslignificação Kraft.

Tabela 5. Metodologias utilizadas para a avaliação do licor

\begin{tabular}{ll}
\hline Ensaio & Norma \\
\hline Residuais de Álcali & TAPPI T $625 \mathrm{~cm}-85$ \\
$\mathrm{pH}$ & TAPPI T $625 \mathrm{~cm}-85$ \\
Teor de sólidos totais & TAPPI T 650 \\
\hline
\end{tabular}

\subsubsection{Pré-deslignificação com $\mathrm{O}_{2}$ e branqueamento da polpa}

As polpas não-branqueadas foram submetidas a uma pré-deslignificação com oxigênio e em seguida branqueadas através da seqüência de branqueamento $D_{0} E_{O P} D_{1}$. Os branqueamentos foram realizados em duplicata.

A pré-deslignificação com oxigênio foi realizada num reator/misturador Quantum - Mark V, usando o equivalente a $250 \mathrm{~g}$ de polpa absolutamente seca, nas condições apresentadas na tabela 6. Estas condições foram mantidas constantes para todas as amostras provenientes dos dois clones estudados. A polpa foi colocada no reator com a carga preestabelecida de $\mathrm{NaOH}$ e na consistência adequada. Após, a polpa foi aquecida até a temperatura desejada. Atingida a temperatura, e sob efeito de agitação constante, injetou-se a carga de $\mathrm{O}_{2}$ preestabelecida e elevou-se a pressão com nitrogênio até o valor desejado. Terminada a reação, foram extraídas amostras do licor residual para análise de pH. A polpa foi transferida e então lavada abundantemente com água desmineralizada.

O estágio $E_{O P}$ também foi efetuado no reator Quantum - Mark $V$ e os estágios $D_{0}$ e $D_{1}$ foram realizados em banho-maria termostatizado. As condições adotadas também constam na tabela 6 . Em cada um dos estágios, a polpa foi 
colocada no reator ou saco de polietileno na consistência adequada e aquecida até a temperatura desejada. No estágio de dioxidação foi feito o controle de pH com ácido sulfúrico $1 \mathrm{~N}$ ou $\mathrm{NaOH} 1 \mathrm{~N}$.

Tabela 6. Condições empregadas na pré-deslignificação com oxigênio e na seqüência de branqueamento

\begin{tabular}{|c|c|c|c|c|}
\hline \multirow{2}{*}{ Condição } & \multicolumn{4}{|c|}{ Estágio de Branqueamento } \\
\hline & Pré- $\mathrm{O}_{2}$ & $\mathrm{D}_{0}$ & $E_{O P}$ & $\mathrm{D}_{1}$ \\
\hline Consistência, \% & 10 & 10 & 10 & 10 \\
\hline Temperatura, ${ }^{\circ} \mathrm{C}$ & 95 & 65 & 90 & 70 \\
\hline Tempo, min. & 60 & 45 & 60 & 180 \\
\hline Pressão inicial, kPa & 500 & - & 200 & - \\
\hline $\mathrm{ClO}_{2}, \mathrm{~kg} / \mathrm{t}$ & - & 25 & - & 10 \\
\hline $\mathrm{O}_{2}, \mathrm{~kg} / \mathrm{t}$ & 18 & - & 6 & - \\
\hline $\mathrm{NaOH}, \mathrm{kg} / \mathrm{t}$ & 20 & - & 7 & - \\
\hline $\mathrm{H}_{2} \mathrm{O}_{2}, \mathrm{~kg} / \mathrm{t}$ & - & - & 5 & - \\
\hline $\mathrm{pH}$ final & \pm 11 & $\pm 3,0$ & \pm 10 & $\pm 4,0$ \\
\hline
\end{tabular}

A determinação do número kappa e viscosidade da polpa foram efetuadas após cada estágio da seqüência de branqueamento. O método utilizado para avaliar o número kappa foi a norma TAPPI T $236 \mathrm{~cm}-85$ e para a viscosidade da celulose a norma SCAN C 15:62 ou manual Viscomat BMT - 8.

O branqueamento foi realizado em 36 amostras de polpas nãobranqueadas ( 2 clones $\times 3$ compostas de madeira/clone $\times 3$ níveis de álcali ativo na polpação/clone $x 2$ repetições do branqueamento). 


\subsubsection{Caracterização da polpa branqueada}

\subsubsection{Morfologia de fibras da polpa branqueada}

A morfologia de fibras da polpa branqueada foi avaliada utilizando-se 0 equipamento Kajaani - Fiber Lab Versão 1.1. Os seguintes parâmetros foram analisados: comprimento médio ponderado da fibra, largura da fibra, diâmetro do lume, espessura da parede da fibra, índice de enfeltramento, coeficiente de flexibilidade da fibra, fração parede da fibra, índice de Runkel da fibra, curvatura da fibra, a "coarseness" da fibra, número de fibras/grama $\times 10^{6}$, teor de finos menores que 0,1 mm aritmético e teor de finos menores que 0,2 $\mathrm{mm}$ aritmético.

A morfologia de fibras foi efetuada em 36 amostras de polpas branqueadas ( 2 clones $\times 3$ compostas de madeira/clone $\times 3$ níveis de álcali ativo na polpação/clone $\times 2$ repetições do branqueamento).

\subsubsection{Refino da polpa branqueada}

As polpas branqueadas foram refinadas em moinho PFI (norma NBR 14345), utilizando o equivalente a $30 \mathrm{~g}$ secas, a uma consistência de 10 \%, nos níveis zero, 900, 1800 e 2700 revoluções. O grau de refino foi avaliado através da determinação do grau Schopper Riegler (SCAN-M3:65). Os refinos foram realizados em duplicata.

O refino foi realizado em 144 amostras de polpas branqueadas (2 clones x 3 compostas de madeira/clone $x 3$ níveis de álcali ativo na polpação/clone $\times 2$ repetições do branqueamento x 4 níveis de refino/clone). 


\subsubsection{Propriedades físico-mecânicas das polpas branqueadas em índice de tração constante e igual a $70 \mathrm{~N} . \mathrm{m} / \mathrm{g}$}

A formação de folhas laboratoriais para os ensaios físico-mecânicos das polpas branqueadas e refinadas no moinho $\mathrm{PFI}$ em quatro níveis de revoluções (zero, 900, 1800 e 2700) foi confeccionada em formador tipo TAPPI. Após, as folhas foram acondicionadas em ambiente climatizado, nas condições de $50 \pm$ $2 \%$ de umidade relativa e temperatura de $23 \pm 2{ }^{\circ} \mathrm{C}$ (TAPPI T 402 om-03). As propriedades físico-mecânicas avaliadas, em números de revoluções préestabelecidos, foram as seguintes:

- Peso Específico Aparente (TAPPI T 220 sp-96);

- Volume Específico Aparente (TAPPI T 220 sp-96);

- Índice de rasgo (TAPPI T 414 om-98);

- Índice de arrebentamento (TAPPI T 403 om-97);

- $\quad$ Índice de tração (TAPPI T 494 om-96);

- Alongamento (TAPPI T 494 om-96);

- Índice de energia absorvida na tração (TAPPI T 494 om-96);

- Índice de rigidez na tração (TAPPI T 494 om-96);

- Opacidade (TAPPI T 425 om-91);

- Ascensão Capilar Klemm (SCAN - P 13:64);

- Resistência ao ar (TAPPI T 406 om-96);

- Índice de retenção de água.

Estas propriedades físico-mecânicas das polpas branqueadas foram analisadas em índice de tração constante e igual a $70 \mathrm{~N} . \mathrm{m} / \mathrm{g}$ visando analisar as diferenças de clones e álcali ativo nesta condição. O índice de tração é um importante parâmetro para definir o grau de refino de diferentes polpas e a 70N.m/g pode ser considerado como padrão para muitos usos finais da polpa de eucalipto (Cotterill e Macrae, 1997). 
A metodologia utilizada para comparar as propriedades físico-mecânicas em índice de tração constante e igual a $70 \mathrm{~N} \cdot \mathrm{m} / \mathrm{g}$ foi efetuada em etapas. A primeira etapa consistiu na obtenção das curvas de refino (equações) através de análises de regressão polinomial ou exponencial e correlação, adotando como variável dependente às propriedades físico-mecânicas e como variável independente o grau Schopper Riegler. A segunda etapa foi entrar na curva de índice de tração em função de grau Schopper Riegler obtido na primeira etapa para determinar qual o grau para a obtenção de índice de tração de 70 N.m/g. A terceira etapa foi a substituição deste grau Schopper Riegler determinado na segunda etapa nas equações das outras propriedades físico-mecânicas avaliadas. Este procedimento foi efetuado para cada repetição do refino/álcali ativo/clone.

\subsubsection{Propriedades físico-mecânicas das polpas branqueadas sem refino}

As propriedades físico-mecânicas das polpas branqueadas foram analisadas sem refino visando analisar as diferenças de clones e álcali ativo para fabricação de papéis para fins sanitários.

\subsubsection{Análise estatística dos resultados}

Todos os resultados obtidos no presente estudo foram analisados utilizando o programa SAS através de análise de variância e teste de comparação de médias Tukey no nível de 5\% de significância. A dispersão dos resultados em relação à média foi expressa pelo desvio padrão.

A análise estatística dos resultados obtidos para as madeiras utilizou 0 procedimento a seguir: 


\begin{tabular}{c|c|c}
\hline Repetições & Clone G-31 & Clone C-41 \\
\hline Composta de madeira 1 & $\mathrm{X}_{\mathrm{ij}}$ & $\mathrm{X}_{\mathrm{ij}}$ \\
\hline Composta de madeira 2 & $\mathrm{X}_{\mathrm{i}}$ & $\mathrm{X}_{\mathrm{ij}}$ \\
\hline Composta de madeira 3 & $\mathrm{X}_{\mathrm{ij}}$ & $\mathrm{X}_{\mathrm{ij}}$ \\
\hline
\end{tabular}

Modelo de experimento: $\left[X_{i j}=\mu+A_{i}+Z_{j(i)}\right]$

$\mathrm{i}=2$ (Fator clone - fator fixo com dois níveis)

$\mathrm{j}=3$ (repetições por clone)

$X_{i j}=$ variável resposta

ANAVA

\begin{tabular}{l|c|c}
\hline \multicolumn{1}{c|}{ Fonte de variação } & \multicolumn{2}{|c}{ Grau de liberdade } \\
\hline Clones & $\mathrm{i}-1$ & 1 \\
\hline Resíduo & $\mathrm{i}(\mathrm{j}-1)$ & 4 \\
\hline Total & $\mathrm{i} \mathrm{j}-1$ & 5 \\
\hline
\end{tabular}

Teste de tukey

$\mathrm{DMS}=\mathrm{q} \cdot \frac{\mathrm{s}}{\sqrt{\mathrm{r}}}$

Onde: $\mathrm{DMS}$ = diferença mínima significativa; $\mathrm{q}$ = valor tabular (2 tratamentos e 4 graus de liberdade do resíduo); s = desvio padrão residual (raiz do quadrado médio do resíduo) e $r$ = número de repetições (3).

A análise estatística dos resultados efetuados na polpa não-branqueada, licor residual, branqueamento, morfologia da fibra e propriedades físicomecânicas, considerando os fatores clone e álcali ativo, foi analisado para obtenção de informações gerais conforme a seguir:

\begin{tabular}{|c|c|c|c|c|c|c|}
\hline \multirow{3}{*}{ Repetições } & \multicolumn{3}{|c|}{ Clone G-31 } & \multicolumn{3}{|c|}{ Clone C-41 } \\
\hline & \multicolumn{3}{|c|}{ Álcali ativo, \%como $\mathrm{Na}_{2} \mathrm{O}$} & \multicolumn{3}{|c|}{ Álcali ativo, \%como $\mathrm{Na}_{2} \mathrm{O}$} \\
\hline & 12,5 & 13,5 & 14,5 & 12,5 & 13,5 & 14,5 \\
\hline Composta 1 & $X_{i j k}$ & $X_{i j k}$ & $X_{i j k}$ & $X_{i j k}$ & $X_{i j k}$ & $X_{i j k}$ \\
\hline Composta 2 & $X_{i j k}$ & $X_{i j k}$ & $X_{i j k}$ & $X_{i j k}$ & $X_{i j k}$ & $X_{i j k}$ \\
\hline Composta 3 & $X_{i j k}$ & $X_{i j k}$ & $X_{i j k}$ & $X_{i j k}$ & $X_{i j k}$ & $X_{i j k}$ \\
\hline
\end{tabular}


Modelo de experimento: $\left[X_{i j k}=\mu+A_{i}+B_{j}+(A B)_{i j}+Z_{k(i j)}\right]$

i = 2 ( Fator clone - fator fixo com dois níveis )

j = 3 ( Fator álcali ativo - fator fixo com três níveis )

$\mathrm{k}=3$ ( repetições/álcali ativo/clone )

$\mathrm{X}_{\mathrm{ijk}}=$ variável resposta

ANAVA

\begin{tabular}{l|c|c}
\hline \multicolumn{1}{c|}{ Fonte de variação } & \multicolumn{2}{c}{ Grau de liberdade } \\
\hline Clone & $\mathrm{i}-1$ & 1 \\
\hline Álcali ativo & $\mathrm{j}-1$ & 2 \\
\hline Clone $x$ Álcali ativo & $(\mathrm{i}-1)(\mathrm{j}-1)$ & 2 \\
\hline Resíduo & $\mathrm{i} \mathrm{j}(\mathrm{k}-1)$ & 12 \\
\hline Total & $\mathrm{i} \mathrm{j} \mathrm{k-1}$ & 17 \\
\hline
\end{tabular}

O objetivo deste modelo de análise de variância foi verificar a influência do clone, álcali ativo e interação clone $x$ álcali ativo na variável resposta. Por se tratar de um experimento fatorial, as informações geradas nesta análise serão mais eficientes que a análise dos fatores de forma isolada.

A análise de variância específica para os fatores clone e álcali ativo foram efetuados através de dois modelos.

O modelo 1 foi à análise de álcali ativo dentro de clone:

$X_{i j k}=\mu+A_{i}+B_{j(i)}+Z_{k(i j)}$

ANAVA

\begin{tabular}{l|c|c}
\hline \multicolumn{1}{c|}{ Fonte de variação } & \multicolumn{2}{|c}{ Grau de liberdade } \\
\hline Clone & $\mathrm{i}-1$ & 1 \\
\hline Álcali ativo (clone) & $\mathrm{i} \mathrm{j}-1)$ & 4 \\
\hline Resíduo & $\mathrm{i} \mathrm{j}(\mathrm{k}-1)$ & 12 \\
\hline Total & $\mathrm{i} \mathrm{j} \mathrm{k} \mathrm{-} \mathrm{1}$ & 17 \\
\hline
\end{tabular}

Decomposição dos graus de liberdade do álcali ativo dentro de clone (GL =4) para os clones $\mathrm{G}-31(\mathrm{GL}=2)$ e $\mathrm{C}-41(\mathrm{GL}=2)$. 
O modelo 2 foi à análise de clones dentro de álcali ativo:

$$
X_{i j k}=\mu+A_{j}+B_{i(j)}+Z_{k(i j)}
$$

ANAVA

\begin{tabular}{l|c|c}
\hline \multicolumn{1}{c|}{ Fonte de variação } & \multicolumn{2}{c}{ Grau de liberdade } \\
\hline Álcali ativo & $\mathrm{j}-1$ & 2 \\
\hline Clone (Álcali ativo) & $\mathrm{j}(\mathrm{i}-1)$ & 3 \\
\hline Resíduo & $\mathrm{i} \mathrm{j}(\mathrm{k}-1)$ & 12 \\
\hline Total & $\mathrm{i} \mathrm{j} \mathrm{k} \mathrm{-} \mathrm{1}$ & 17 \\
\hline
\end{tabular}

Decomposição dos graus de liberdade de clone dentro de álcali ativo (GL =3) para álcali ativo 12,5\% ( $G L=1), 13,5 \%(G L=1)$ e 14,5\% ( $G L=1)$.

O exemplo a seguir mostra estas análises de variâncias para o número kappa após polpação Kraft, uma das variáveis respostas deste trabalho, para analisar os efeitos dos fatores clone, álcali ativo e interação entre eles:

ANAVA geral para número kappa após deslignificação Kraft

\begin{tabular}{l|c|c|c|c|c}
\hline \multicolumn{1}{c|}{ FV } & GL & SQ & QM & F calculado & Prob. $>$ F \\
\hline Clone & 1 & 0,2222 & 0,2222 & $5,48^{*}$ & 0,0373 \\
\hline Álcali Ativo & 2 & 42,6878 & 21,3439 & $526,29^{\star}$ & 0,0001 \\
\hline ClonexA.A. & 2 & 2,8078 & 1,4039 & $34,62^{\star}$ & 0,0001 \\
\hline Resíduo & 12 & 0,4867 & 0,0406 & & \\
\hline Total & 17 & 46,2044 & & & \\
\hline
\end{tabular}

A.A. $=$ Álcali Ativo

ANAVA do álcali ativo dentro de clone para número kappa após deslignificação Kraft

\begin{tabular}{l|c|c|c|c|c}
\hline \multicolumn{1}{c|}{ FV } & GL & SQ & QM & F calculado & Prob. > F \\
\hline Clone & 1 & 0,2222 & 0,2222 & $5,48^{*}$ & 0,0373 \\
\hline A.A. (clone) & 4 & 45,4955 & 1,3739 & $33,84^{*}$ & 0,0001 \\
\hline Resíduo & 12 & 0,4867 & 0,0406 & & \\
\hline Total & 17 & 46,2064 & & & \\
\hline
\end{tabular}


ANAVA da decomposição dos graus de liberdade de álcali ativo dentro de clone para número kappa após deslignificação Kraft

\begin{tabular}{l|c|c|c|c|c}
\hline \multicolumn{1}{c|}{ FV } & GL & SQ & QM & F calculado & Prob. > F \\
\hline Clone G-31 & 2 & 12,5088 & 6,2544 & $154,2^{*}$ & 0,0001 \\
\hline Clone C-41 & 2 & 32,9867 & 16,4933 & $406,7^{*}$ & 0,0001 \\
\hline Total & 4 & 45,4955 & & & \\
\hline
\end{tabular}

ANAVA do clone dentro de álcali ativo para número kappa após deslignificação Kraft

\begin{tabular}{l|c|c|c|c|c}
\multicolumn{1}{c|}{ FV } & GL & SQ & QM & F calculado & Prob. $>$ F \\
\hline Álcali ativo & 2 & 42,6878 & 21,3439 & $526,29^{*}$ & 0,0001 \\
\hline Clone (A.A.) & 3 & 3,0300 & 1,0100 & $24,88^{*}$ & 0,0001 \\
\hline Resíduo & 12 & 0,4866 & 0,0406 & & \\
\hline Total & 17 & 46,2044 & & & \\
\hline A.A Álcali Ativo
\end{tabular}

ANAVA da decomposição dos graus de liberdade de clone dentro de álcali ativo para número kappa após deslignificação Kraft

\begin{tabular}{l|c|c|c|c|c}
\hline \multicolumn{1}{c|}{ FV } & GL & SQ & QM & F calculado & Prob. $>$ F \\
\hline A.A. $=12,5 \%$ & 1 & 1,7067 & 1,7067 & $42,08^{\star}$ & 0,0001 \\
\hline A.A. $=13,5 \%$ & 1 & 0,2817 & 0,2817 & $6,95^{*}$ & 0,0218 \\
\hline A.A. $=14,5 \%$ & 1 & 1,0417 & 1,0417 & $25,69^{\star}$ & 0,0003 \\
\hline Total & 3 & 3,0301 & & & \\
\hline A.A. Álcali Ativo &
\end{tabular}

Todos os resultados obtidos para polpa não-branqueada, licor residual, branqueamento, morfologia da fibra e propriedades físico-mecânicas, considerando os fatores clone e álcali ativo foram analisados desta forma. Os resultados destas análises estatísticas foram sintetizados e apresentados na forma gráfica utilizando o programa Origin. A seguir apresenta-se uma figura, como exemplo, para número kappa após polpação mostrando como foram apresentados os resultados com todas informações necessárias para análise e discussão. As análises de variância para todas propriedades não serão apresentadas neste estudo, mas serão utilizadas para explicar os resultados obtidos. 


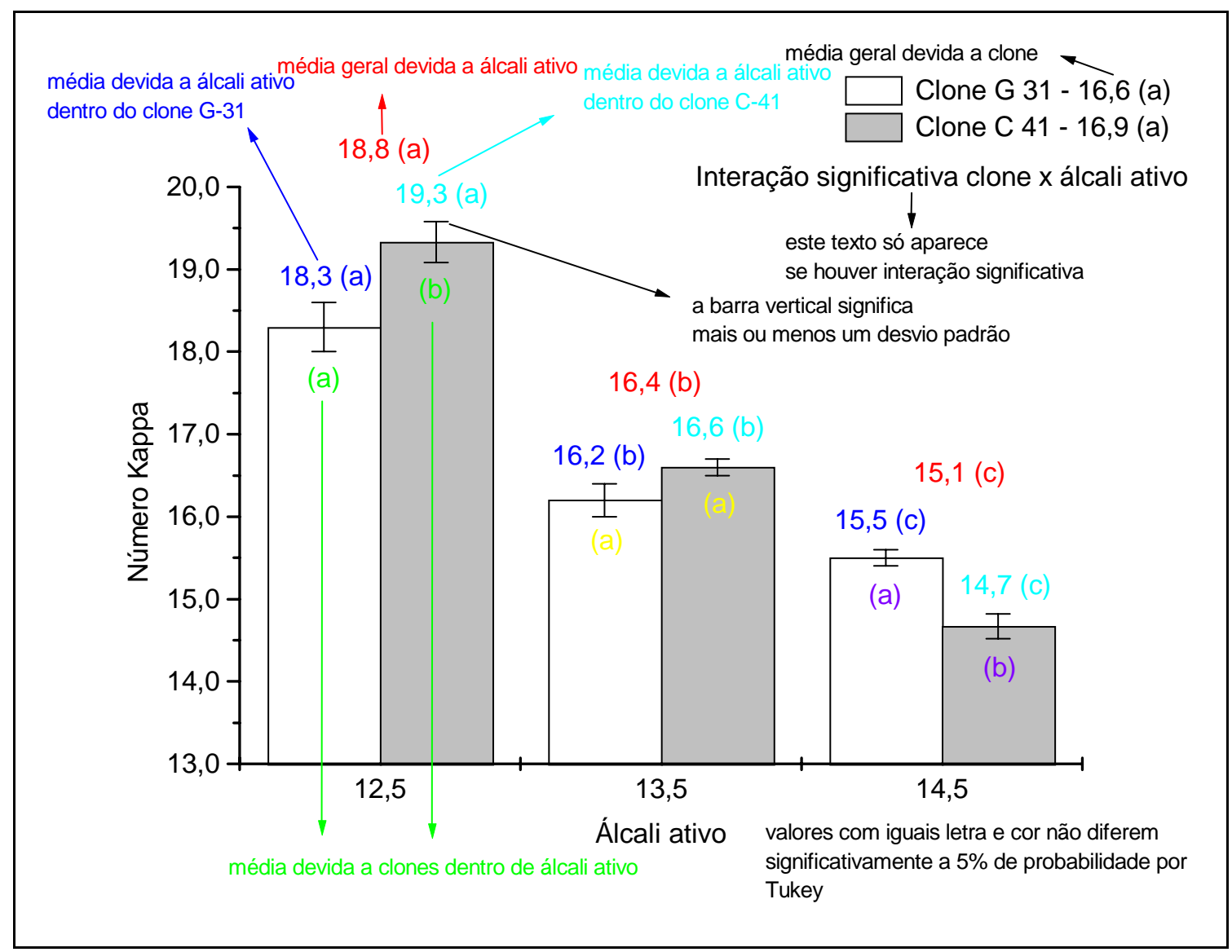




\section{RESULTADOS E DISCUSSÃO}

\subsection{Qualidade da madeira}

A qualidade da madeira dos dois clones (G-31 e C-41) foi analisada em relação à densidade básica, holocelulose, extrativos totais e ligninas Klason total, insolúvel e solúvel.

A Figura 1 mostra os valores médios e desvio padrão para densidade básica e componentes químicos dos clones G-31 e C-41. Conforme pode ser observado, a madeira do clone G-31 caracterizou por apresentar menor densidade básica e teor de holocelulose e maiores teores de extrativos totais e ligninas Klason total, insolúvel e solúvel. A partir destas diferenças entre os clones pode-se esperar comportamentos diferenciados nos parâmetros da polpação Kraft, licor residual da polpação Kraft e branqueamento.

O clone G-31 apresentou densidade básica de $0,440 \mathrm{~g} / \mathrm{cm}^{3}$ e o clone C41 densidade básica de $0,508 \mathrm{~g} / \mathrm{cm}^{3}$. A comparação entre as magnitudes dos valores de densidade básica dos clones permite afirmar que este parâmetro exercerá consideráveis influências em várias etapas do processo de polpação e branqueamento e na qualidade final da polpa branqueada.

O clone G-31 apresentou maiores teores de extrativos (+0,58\%), lignina total $(+1,93 \%)$, lignina insolúvel $(+1,15 \%)$ e lignina solúvel $(+0,78 \%)$ e menor teor de holocelulose $(-2,51 \%)$ quando comparado com o clone C-41.

A análise conjunta da densidade básica e composição química da madeira dos clones associada a diferentes condições de polpação é que pode explicar de forma mais adequada o comportamento diferenciado dos clones. 

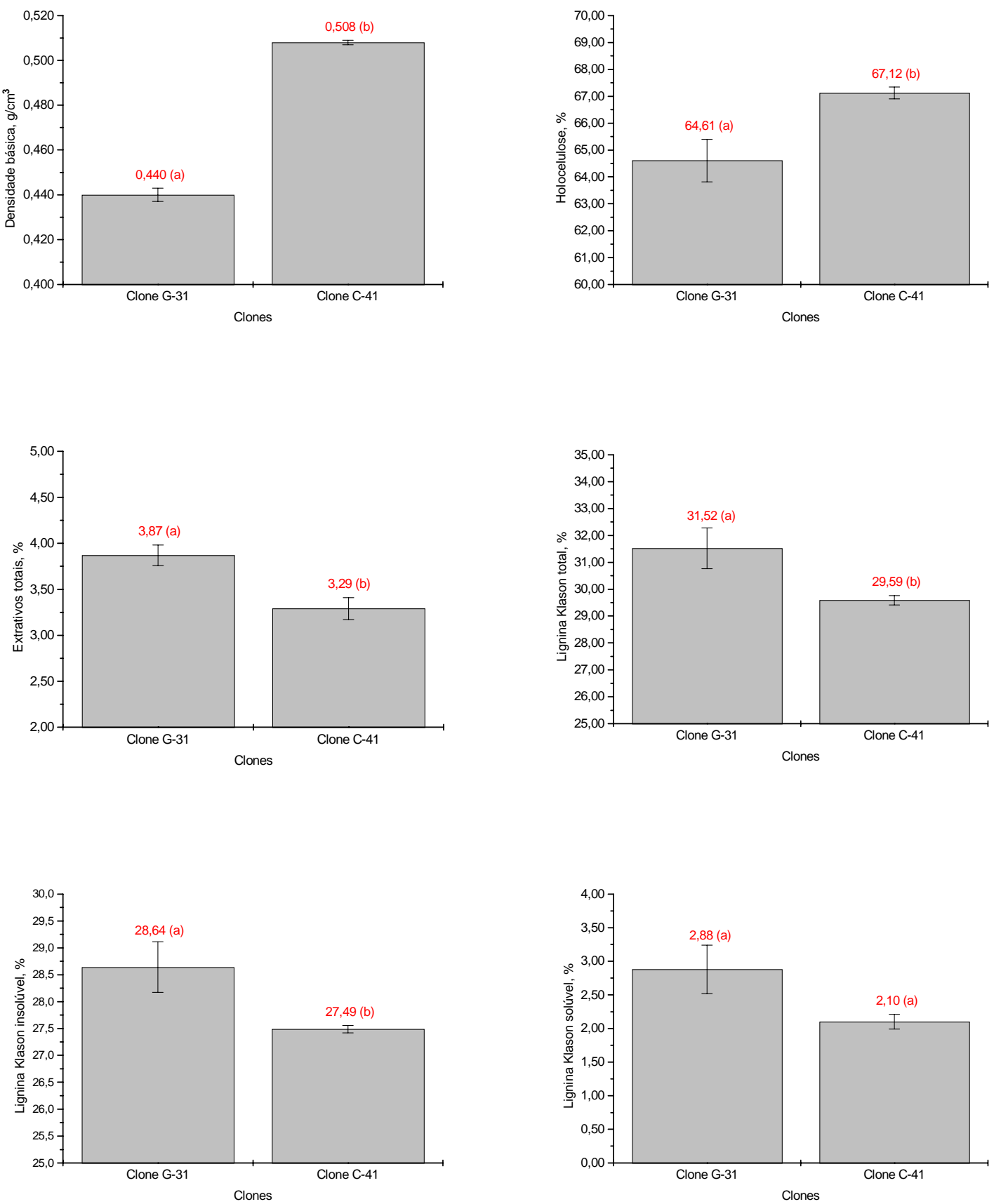

Figura 1 - Densidade básica e composição química dos clones G-31 e C-41 


\subsection{Polpação Kraft}

A polpação dos dois clones (G-31 e C-41) nos três níveis de álcali ativo $(12,5 \%, 13,5 \%$ e $14,5 \%)$ foi analisada considerando os rendimentos, teores de rejeitos, número kappa, viscosidade intrínseca e consumo específico de madeira.

A Figura 2 mostra os rendimentos brutos das polpações Kraft. A análise de variância geral mostrou efeito significativo, somente, para álcali ativo no rendimento bruto. A análise de variância de álcali ativo dentro de clone foi significativa, em ordem decrescente, para o clone G-31 e clone C-41. A análise de variância de clone dentro de álcali ativo não foi significativa para 12,5\%, $13,5 \%$ e $14,5 \%$ de álcali ativo.

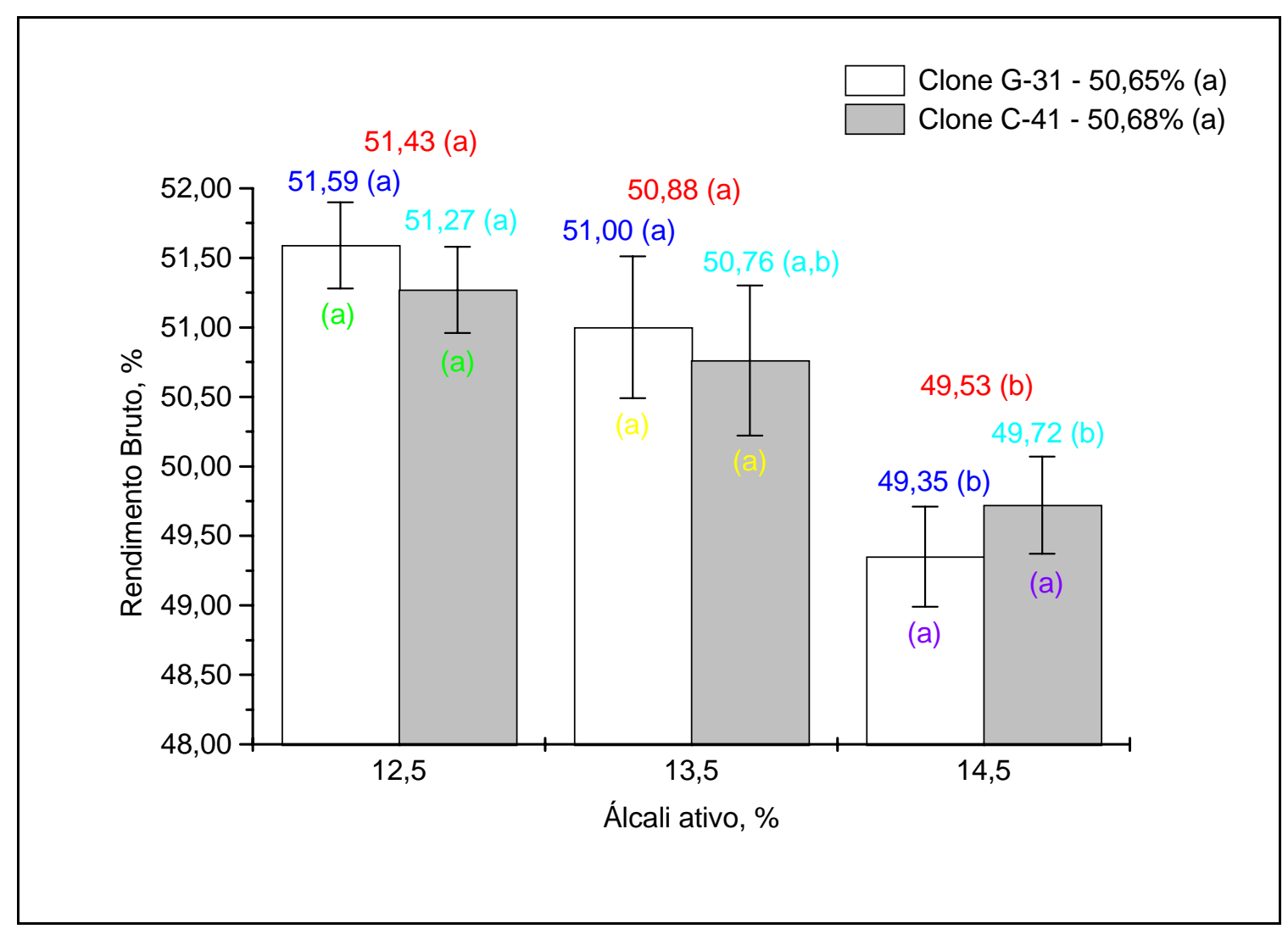

Figura 2 - Rendimento bruto da polpação Kraft 
Os resultados obtidos, através do teste de comparação de médias de Tukey, para clone dentro de álcali ativo apresentaram valores de rendimento bruto muito semelhantes, apesar dos clones apresentarem composição química significativamente diferente. Entretanto, nota-se uma tendência de redução do rendimento bruto com o aumento da carga de álcali ativo do processo de polpação dentro de clone, sendo mais pronunciada para o clone G-31. Tal comportamento está associado à perda de polissacarídeos, principalmente os de baixa massa molecular, ocasionado pelas reações de degradação e dissolução dos mesmos. O fator mais importante nesta variável foi a carga de álcali ativo.

A Figura 3 refere-se aos rendimentos depurados das polpações Kraft. A análise de variância geral mostrou efeito significativo somente para álcali ativo no rendimento depurado. A análise de variância de álcali ativo dentro de clone foi significativa, em ordem decrescente, para o clone G-31 e clone C-41. A análise de variância de clone dentro de álcali ativo não foi significativa para $12,5 \%, 13,5 \%$ e $14,5 \%$ de álcali ativo. 


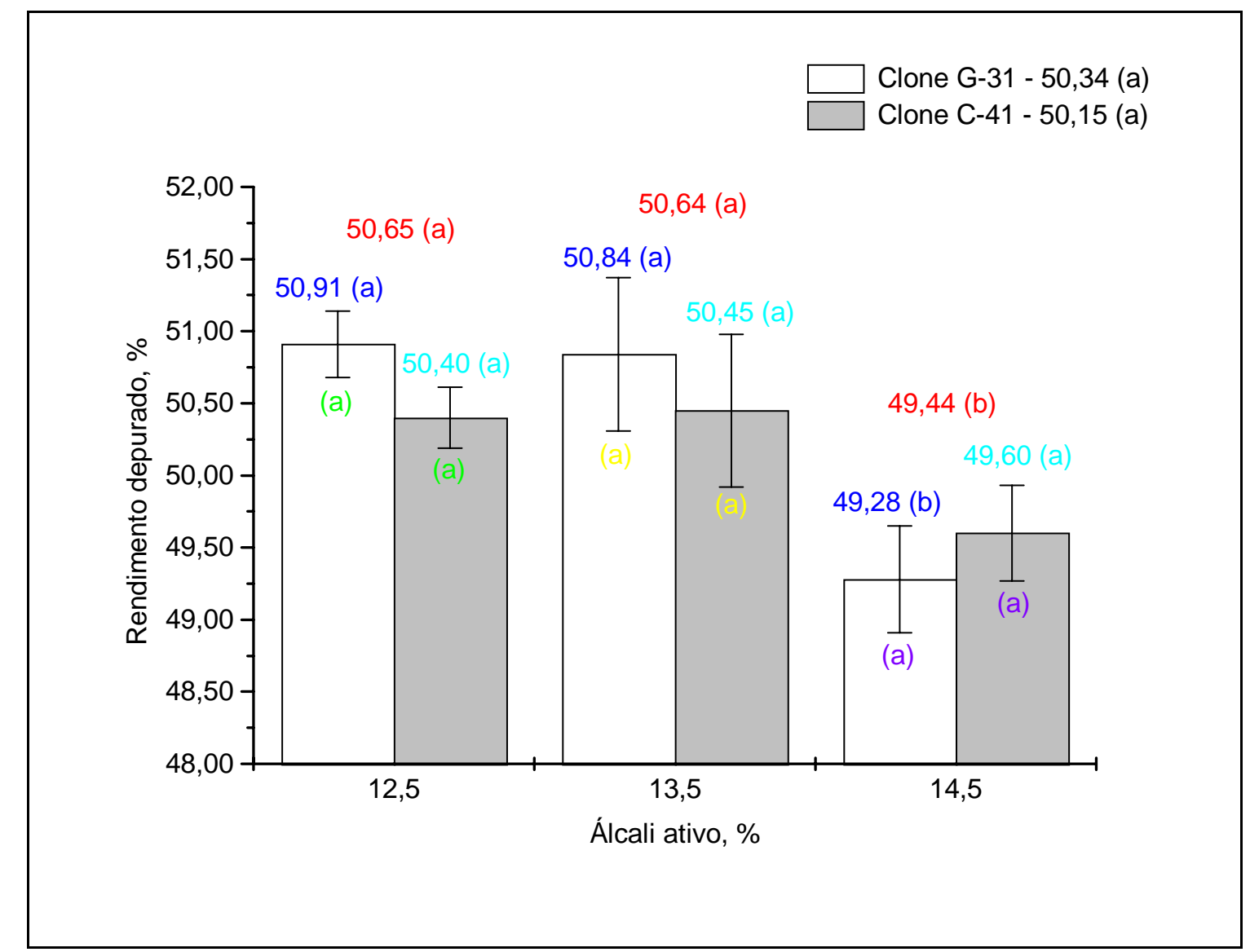

Figura 3 - Rendimento depurado da polpa

Os resultados obtidos, através do teste de Tukey, para rendimento depurado mostram um comportamento muito semelhante àquele encontrado para rendimento bruto. Os resultados da figura 3 indicam que a elevação da carga alcalina dentro de clone apresentou efeito significativo no decréscimo do rendimento depurado, o que pode estar relacionado à remoção de polissacarídeos, principalmente as hemiceluloses. Não houve efeito significativo dos clones dentro de álcali ativo, embora tenham densidades básicas e composições químicas significativamente diferentes. Foelkel (1974), também, não encontrou correlação entre rendimento gravimétrico e densidade básica. Entretanto, Vasconcelos Dias \& Cláudio-da-Silva Júnior (1985) utilizando para o estudo 25 árvores de Eucalyptus grandis de 7 anos concluíram que o 
rendimento na polpação atinge um máximo, em densidade básica no DAP próxima a $0,470 \mathrm{~g} / \mathrm{cm}^{3}$, e decresce com um aumento da mesma. Este fato pode ser explicado como uma perda na capacidade de impregnação dos cavacos, pelo licor de polpação, para madeiras densas (Wehr, 1991).

Os clones se comportaram de forma diferente dentro de álcali ativo. $\mathrm{O}$ clone C-41 apresentou rendimentos depurados, estatisticamente, iguais. O clone G-31 apresentou rendimento depurado significativamente inferior em 14,5\% de álcali ativo. Este rendimento depurado inferior está associado aos teores mais elevados de extrativos e ligninas insolúvel e solúvel no clone G-31. Wehr (1991) em estudo com 4 lotes de tipos diferentes de Eucalyptus grandis verificou que madeiras com baixo teor de extrativos e lignina conduzem a um aumento no rendimento. $\mathrm{O}$ álcali ativo foi fator que exerceu maior influência neste parâmetro.

A Figura 4 mostra o teor de rejeitos expresso base madeira. A análise de variância geral mostrou efeito significativo, em ordem decrescente, para álcali ativo e clone no teor de rejeitos base madeira. A análise de variância de álcali ativo dentro de clone foi significativa, em ordem decrescente, para o clone C-41 e clone G-31. A análise de variância de clone dentro de álcali ativo foi significativa, em ordem decrescente, para 12,5\% e 13,5\% de álcali ativo.

Conforme pode ser observado, o clone C-41 apresentou um maior teor de rejeitos base madeira que o clone G-31. Esse resultado está de acordo com aquele obtido por Vasconcelos Dias \& Cláudio-da-Silva Jr. (1985) que concluiu que há uma elevação constante no teor de rejeitos quando a densidade básica aumenta de $470 \mathrm{Kg} / \mathrm{m}^{3}$ a $666 \mathrm{Kg} / \mathrm{m}^{3}$. 


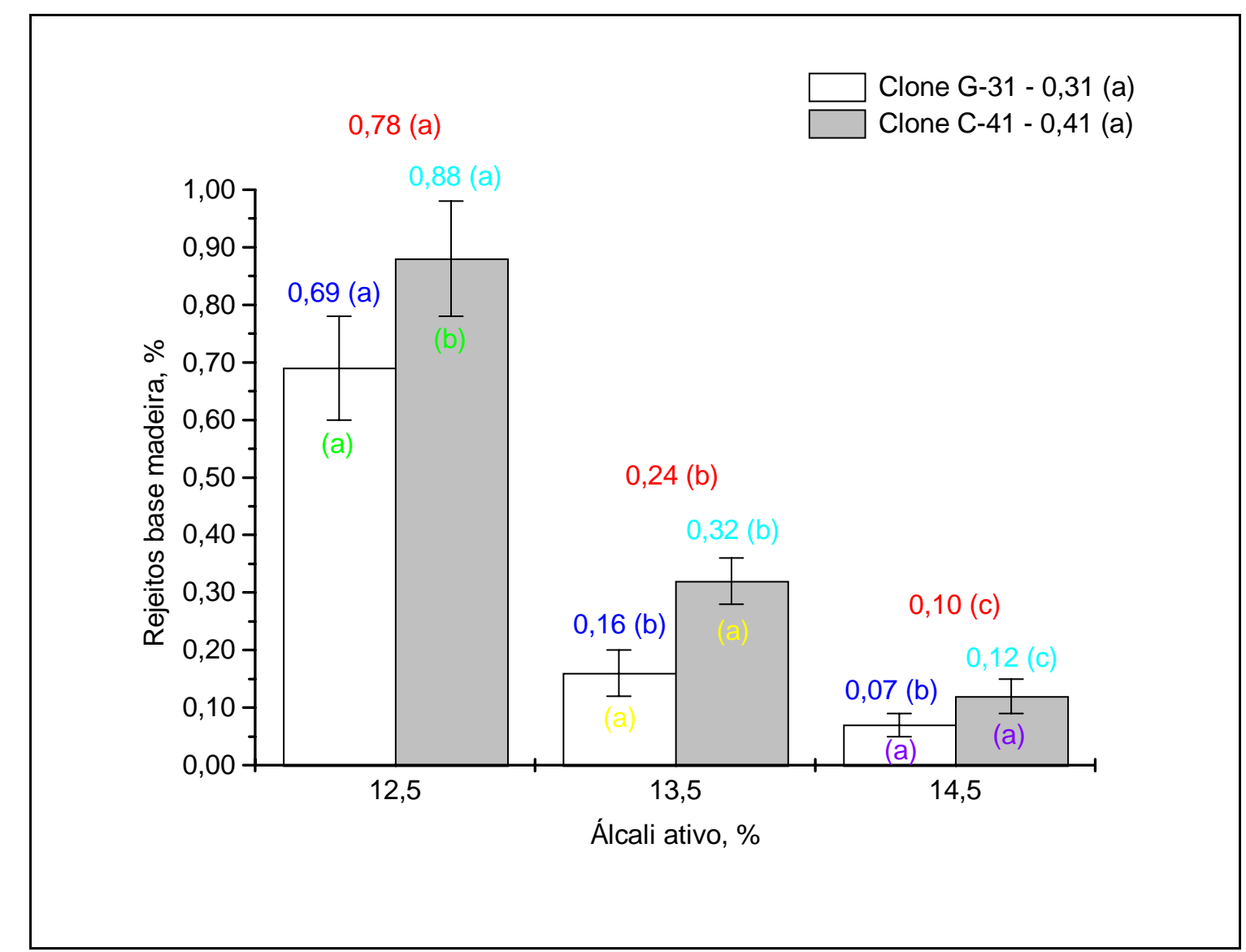

Figura 4 - Teor de rejeitos base madeira

Os resultados do Teste de Tukey mostram que a análise de clone dentro de álcali ativo foi significativa, somente, em 12,5\% de álcali ativo. A análise de álcali ativo dentro de clone revela comportamento distinto para os clones. O teor de rejeitos para o clone G-31 decresceu significativamente até 13,5\% de álcali ativo. A partir desta carga, o decréscimo no teor de rejeitos não foi significativo. O teor de rejeitos para o clone C-41 decresceu significativamente em todas cargas de álcali ativo. Este resultado mostra que o clone C-41 necessitará de maior carga de álcali ativo que o clone G-31 para determinado teor de rejeitos. O primeiro fator mais importante foi a carga de álcali ativo e em segundo lugar o clone no teor de rejeitos base madeira. 
A Figura 5 mostra o teor de rejeitos expresso base celulose. A análise de variância geral mostrou efeito significativo, em ordem decrescente, para álcali ativo e clone no teor de rejeitos base celulose. A análise de variância de álcali ativo dentro de clone foi significativa, em ordem decrescente, para o clone C-41 e clone G-31. A análise de variância de clone dentro de álcali ativo foi significativa, em ordem decrescente, para 12,5\% e 13,5\% de álcali ativo.

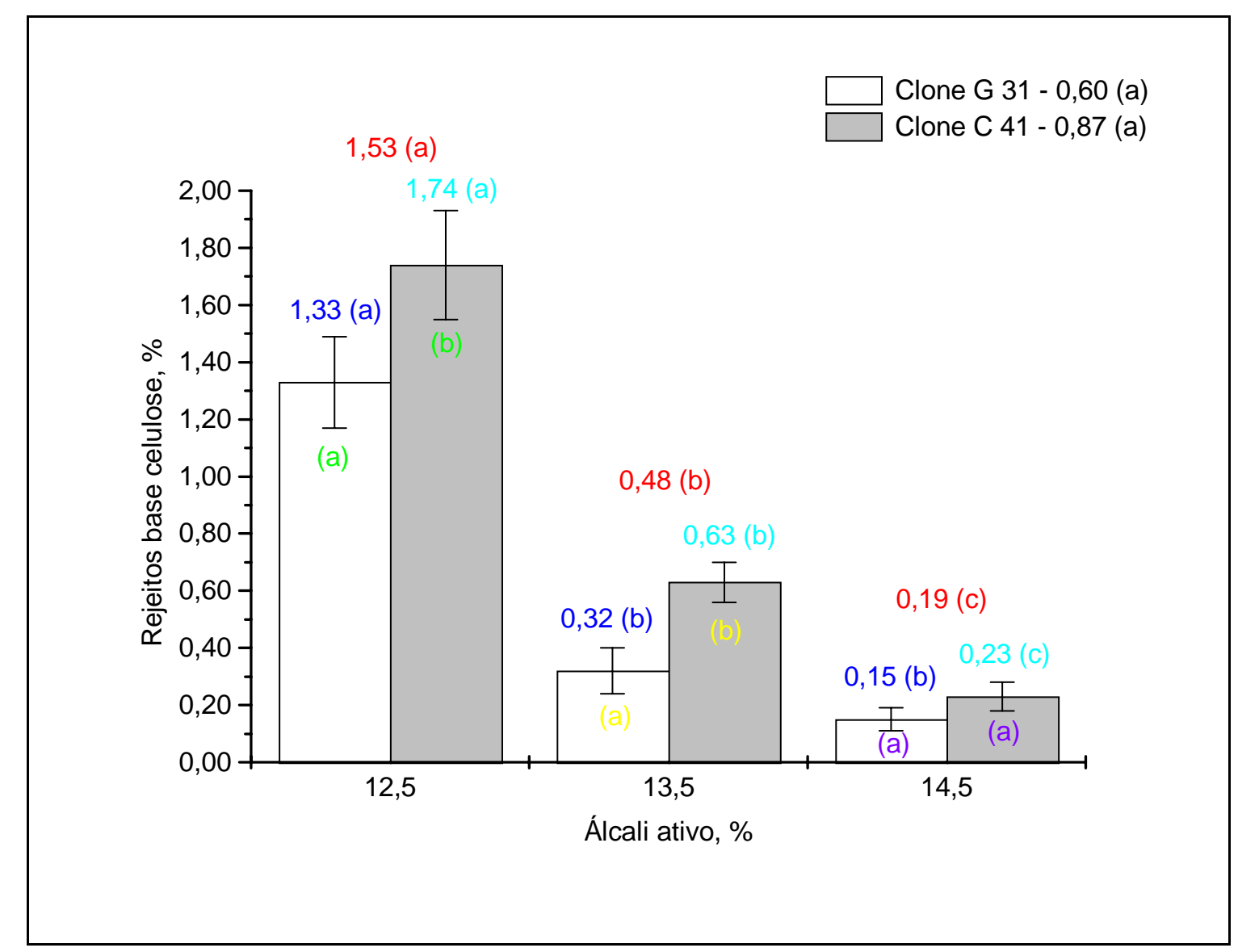

Figura 5 - Teor de rejeitos base celulose

Os resultados obtidos pelo Teste de Tukey para teor de rejeitos base celulose são muito semelhantes àqueles obtidos para teor de rejeitos base madeira. A carga de álcali ativo foi mais significativa que o clone no teor de rejeitos base celulose. 
A Figura 6 mostra o número kappa da polpa. A análise de variância geral mostrou efeito significativo, em ordem decrescente, para álcali ativo, interação clone x álcali ativo e clone no número kappa. A interação significativa indica que o comportamento dos clones depende das cargas de álcali ativo. Neste caso, as médias gerais não podem ser comparadas. A análise de variância de álcali ativo dentro de clone foi significativa, em ordem decrescente, para o clone C-41 e clone G-31. A análise de variância de clone dentro de álcali ativo foi significativa, em ordem decrescente, para 12,5\%, 14,5\% e 13,5\% de álcali ativo.

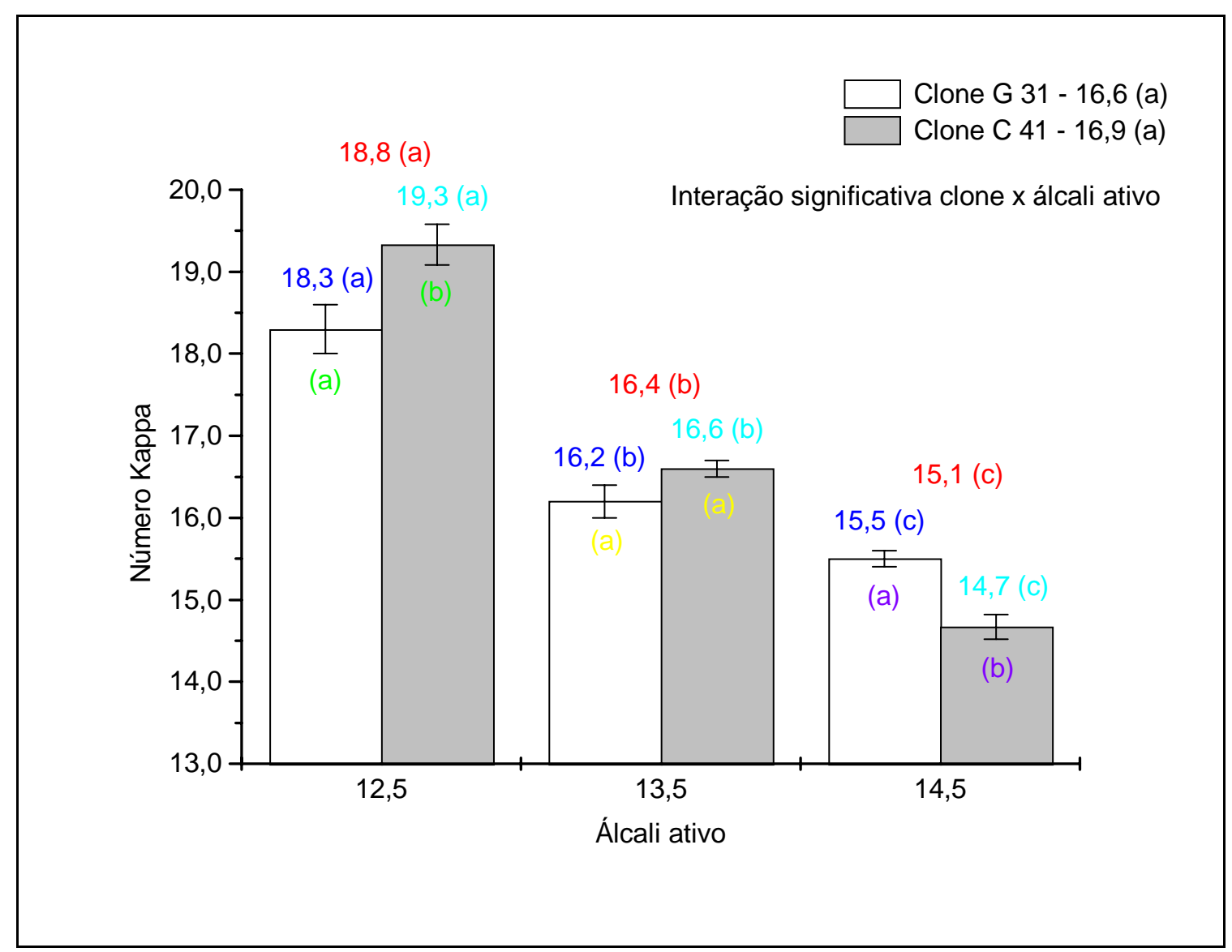

Figura 6 - Número kappa da polpa

Conforme pode ser observado na Figura 6, o resultado do teste de Tukey mostra que a análise de clone dentro de álcali ativo mostrou comportamento 
diferenciado. O clone G-31 apresentou menor número kappa que o clone C-41 em 12,5\% de álcali ativo. Na carga de 14,5\% de álcali ativo, o clone G-31 apresentou maior número kappa que o clone C-41. Este comportamento diferenciado dos clones nas cargas de álcali ativo foi detectado como interação significativa clone $x$ álcali ativo na análise de variância geral.

A deslignificação da madeira é função de três parâmetros: teor de lignina na madeira, densidade básica da madeira (fenômenos de transporte) e estrutura da lignina (teor de guaiacila/siringila). O menor número kappa do clone G-31 em 12,5\% de álcali ativo pode ser atribuído a sua menor densidade básica, embora com maior teor de lignina na madeira. O menor número kappa do clone C-41 em 14,5\% de álcali ativo pode ser atribuído ao menor teor de lignina, embora com maior densidade básica da madeira. Este resultado mostra que a deslignificação deve ser explicada analisando os parâmetros influentes em conjunto e não de forma isolada.

Em um trabalho sobre qualidade da madeira, Silva Jr. et al. (1996) mostraram linhas de iso-kappas para E. grandis e E. urophylla, como função do teor de lignina e densidade básica da madeira. O termo iso-kappa significa linha de mesmo número kappa, que pode ser função de duas outras características da madeira e/ou processo de polpação. A interpretação das linhas de iso-kappa revela que madeiras de alta densidade básica com baixo teor de lignina e madeiras de baixa densidade com alto teor de lignina podem gerar polpas de mesmo número kappa quando submetidas a uma mesma condição de polpação.

A análise de álcali ativo dentro de clone revela comportamento diferente para os clones. O número kappa em função do álcali ativo mostrou tendência de queda exponencial para o clone G-31 e linear para o clone C-41. Isto significa que o clone G-31 foi menos sensível a variação de álcali ativo que o clone C-41 em relação ao número kappa. Na polpação se consegue retirar a maior parte da lignina da madeira com os reagentes nucleofílicos $\left(\mathrm{OH}^{-}\right.$e $\left.\mathrm{SH}^{-}\right)$. Em altas cargas de álcali ativo vai ficando cada vez mais difícil retirar a lignina da madeira com estes reagentes. Isto pôde ser verificado para o clone G-31. Neste ponto a 
polpação deve ser interrompida e a retirada da lignina residual da polpa deve ser efetuada com os reagentes eletrofílicos da pré-deslignificação com oxigênio e estágios da seqüência de branqueamento. O processo de polpação e branqueamento pode ser explicado como uma alternância de reações nucleofílicas e eletrofílicas.

A questão que surge é se esses teores de lignina residual na polpa irão alterar a pré-deslignificação com oxigênio e estágios da seqüência de branqueamento. Esta questão será respondida adiante em branqueamento. Conforme demonstrado, os fatores em ordem de importância no número kappa foram: álcali ativo, interação clone $x$ álcali ativo e clone.

A Figura 7 mostra a viscosidade intrínseca da celulose. A análise de variância geral mostrou efeito significativo, em ordem decrescente, para álcali ativo e clone na viscosidade intrínseca da celulose. A análise de variância de álcali ativo dentro de clone foi significativa, em ordem decrescente, para o clone G-31 e clone C-41. A análise de variância de clone dentro de álcali ativo foi significativa, somente, para $13,5 \%$ de álcali ativo. 


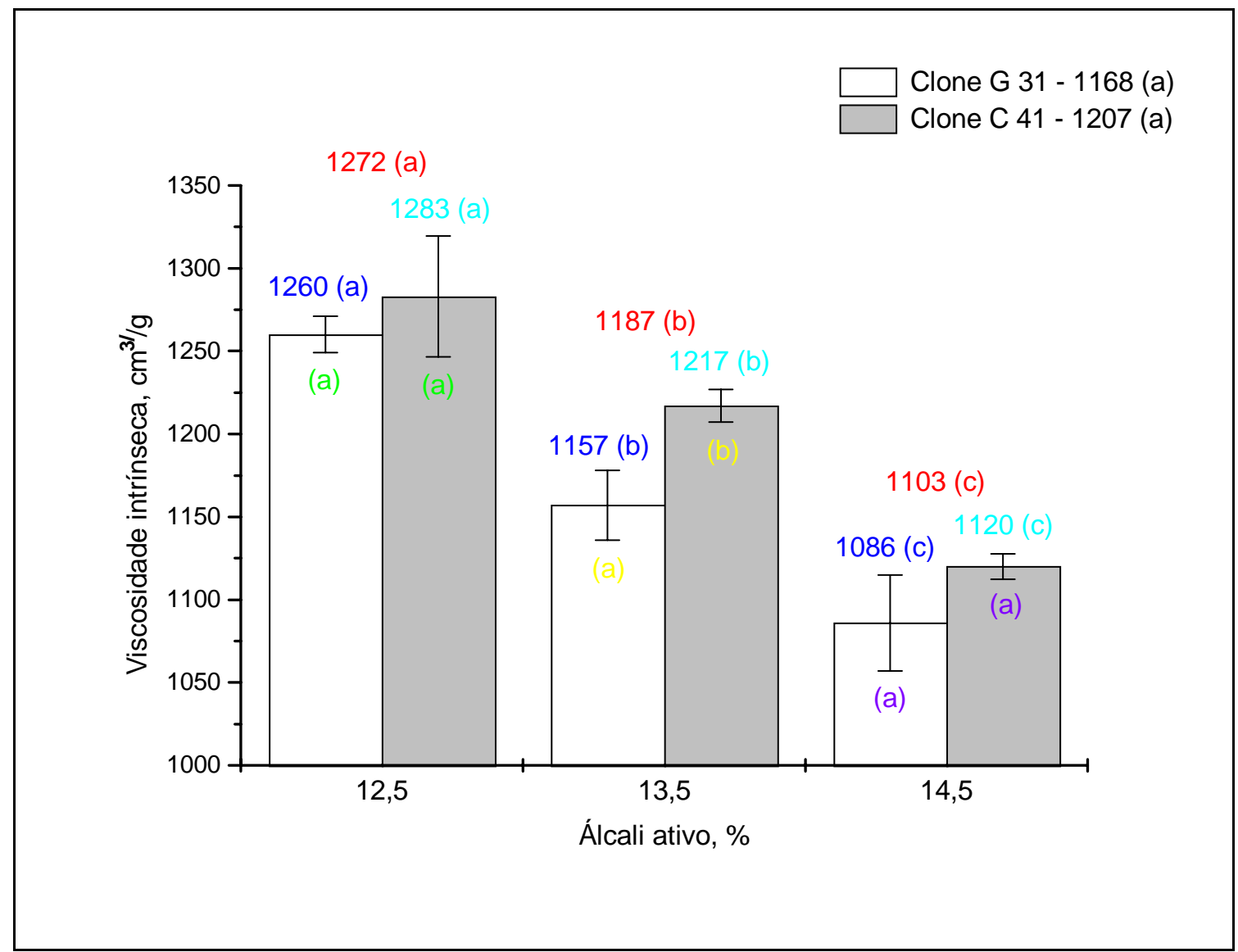

Figura 7 - Viscosidade intrínseca da celulose

Os resultados do Teste de Tukey mostram que a análise de clone dentro de álcali ativo mostrou maior viscosidade da celulose para o clone C-41 sendo significativo, somente, para $13,5 \%$ de álcali ativo. A análise de álcali ativo dentro de clone mostra comportamentos distintos para os clones. A análise de variância revelou uma influência mais significativa para o clone G-31 em comparação com o clone C-41, ou seja, maior queda de viscosidade para o clone G-31. A seletividade (relação viscosidade/número kappa) mostra como foi o comportamento de álcali ativo dentro de clone. O clone G-31 (12,5\%, 13,5\% e 14,5\% de álcali ativo) apresentou, respectivamente, as seguintes seletividades: 68,9 - 71,4 - 70,1. O clone C-41 (12,5\%, 13,5\% e 14,5\% de álcali ativo) apresentou, respectivamente, as seguintes seletividades: $66,5-73,3-76,2$. A 
seletividade do clone G-31 foi maior, somente, em $12,5 \%$ de álcali ativo e a partir de 13,5\% começou a decrescer. A seletividade do clone C-41 elevou continuamente, mesmo em 14,5\% de álcali ativo. As análises das Figuras 6 e 7 explicam este comportamento.

Os fatores que influenciaram na viscosidade da celulose, em ordem de importância, foram: álcali ativo e clone.

A Figura 8 mostra o consumo específico de madeira. A análise de variância geral mostrou efeito significativo, em ordem decrescente, para clone e álcali ativo no consumo específico de madeira. A análise de variância de álcali ativo dentro de clone foi significativa, somente, para o clone G-31. A análise de variância de clone dentro de álcali ativo foi significativa, em ordem decrescente, para $14,5 \%, 13,5 \%$ e $12,5 \%$ de álcali ativo. 


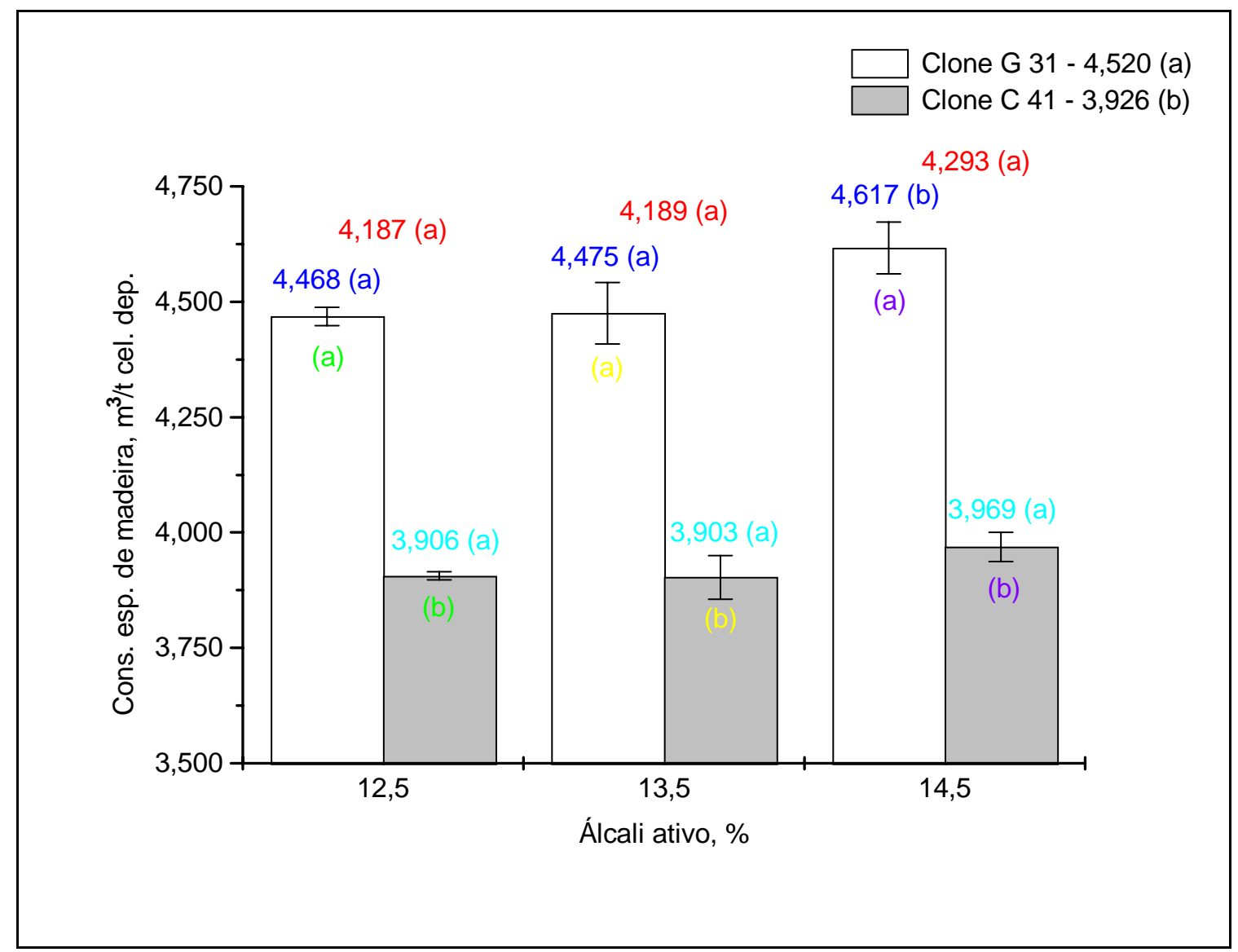

Figura 8 - Consumo específico de madeira

De acordo com os resultados do Teste de Tukey, a análise de clone dentro de álcali ativo foi significativa em todas as cargas de álcali ativo e se deve em primeiro lugar as diferentes densidades básicas e em segundo lugar aos rendimentos depurados dos clones. A análise de álcali ativo dentro de clones mostra comportamentos diferentes para os clones. O clone C-41 apresentou consumo específico de madeira semelhante em todas cargas de álcali ativo. O clone G-31 apresentou maior consumo específico de madeira em álcali ativo $14,5 \%$ devido ao menor rendimento depurado.

O consumo específico de madeira é um importante parâmetro no processo de polpação. Quanto mais densa a madeira, menor será o volume 
necessário de madeira para produzir uma tonelada de polpa porque a massa contida no digestor é maior. A demanda de madeira é menor para madeiras mais densas, ou seja, quanto maior a densidade básica da madeira, menor será seu consumo específico e menor será o custo variável da produção de celulose. Essa vantagem, em projetos novos onde o ciclo de recuperação é dimensionado para maiores cargas de sólidos totais do licor residual, deve ser considerada nos programas de melhoramento florestal (Mokfienski et al., 2003).

Conforme pôde ser observado, o fator clone foi o mais importante e posteriormente o álcali ativo no consumo específico de madeira.

\subsection{Licor residual da polpação Kraft}

O licor residual da polpação Kraft dos dois clones (G-31 e C-41) nos três níveis de álcali ativo $(12,5 \%, 13,5 \%$ e $14,5 \%)$ foi analisado quanto ao $\mathrm{pH}$, teor de sólidos, densidade, álcali ativo, álcali efetivo, álcali total e álcalis ativos consumidos bases madeira e produto químico.

A Figura 9 mostra o pH do licor residual das polpações Kraft. A análise de variância geral mostrou efeito significativo, somente, para álcali ativo no $\mathrm{pH}$ do licor residual. A análise de variância de álcali ativo dentro de clone foi significativa, em ordem decrescente, para o clone C-41 e clone G-31. A análise de variância de clone dentro de álcali ativo não foi significativa para $12,5 \%$, $13,5 \%$ e $14,5 \%$ de álcali ativo. 


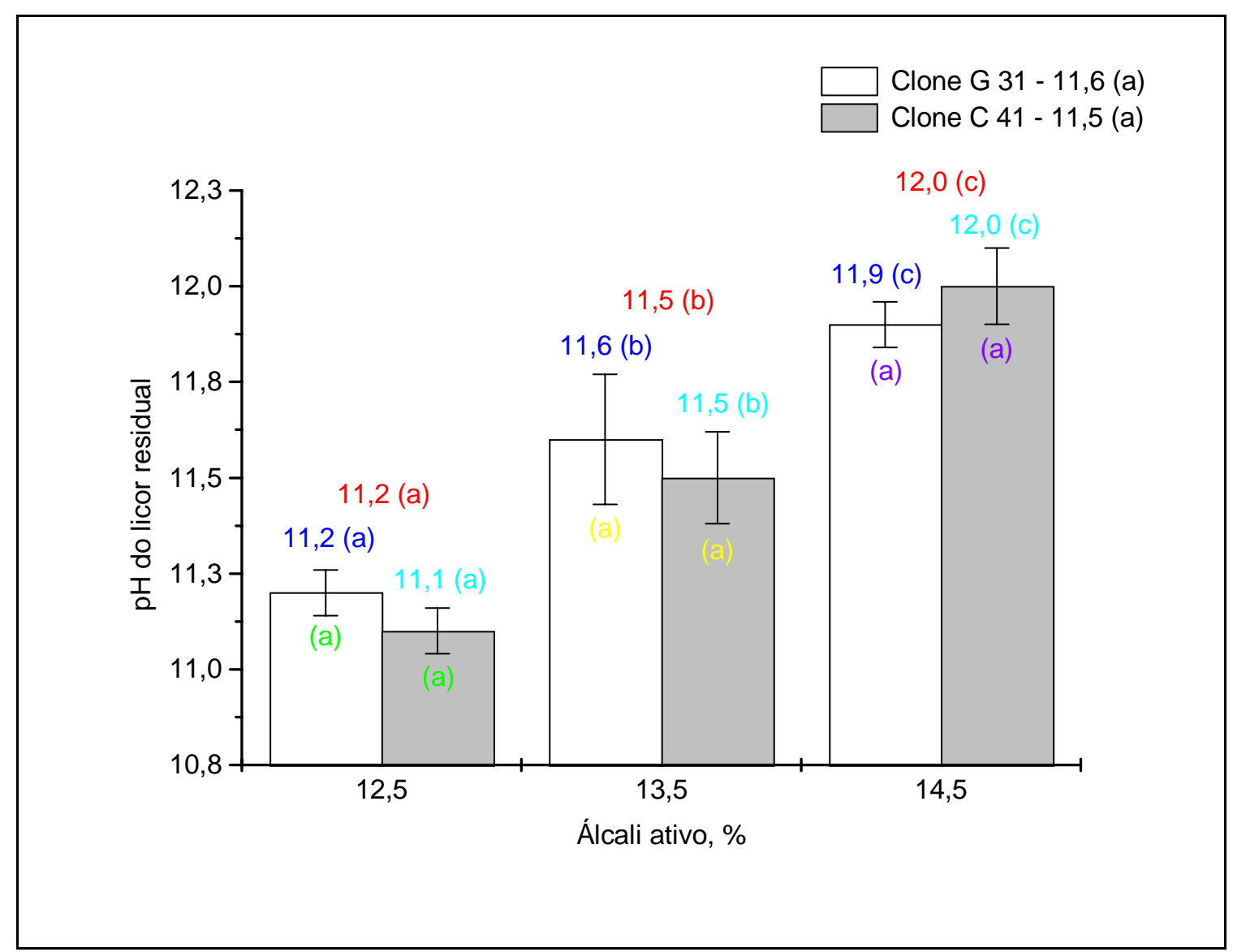

Figura 9 - pH do licor residual das polpações Kraft

Os resultados obtidos através do Teste de Tukey mostram que a análise de variância de álcali ativo dentro de clone revelou comportamento distinto para os clones. $\mathrm{O}$ pH do licor residual para o clone $\mathrm{C}$-41 se elevou de forma mais pronunciada que o clone G-31 com a elevação da carga de álcali ativo. Isto significa que sobrou mais álcali nas polpações do clone C-41 e se deve aos menores teores de extrativos, lignina, e menor degradação de polissacarídeos durante polpação deste clone.

Como mostra a figura 9, maiores valores de $\mathrm{pH}$ do licor residual são obtidos à medida que uma maior carga alcalina é aplicada. As magnitudes dos valores foram superiores a $\mathrm{pH} 11$, estando, portanto dentro de uma faixa 
considerada normal. É importante ressaltar que a queda do $\mathrm{pH}$ final do licor de polpação pode implicar na re-precipitação da lignina acarretando problemas na etapa de branqueamento. O fator mais importante que influenciou no $\mathrm{pH}$ do licor residual foi o álcali ativo da polpação.

A Figura 10 refere-se ao teor de sólidos do licor residual das polpações Kraft. A análise de variância geral mostrou efeito significativo, em ordem decrescente, para álcali ativo e clone no teor de sólidos do licor residual. A análise de variância de álcali ativo dentro de clone foi significativa, em ordem decrescente, para o clone G-31 e clone C-41. A análise de variância de clone dentro de álcali ativo foi significativa, somente, para 14,5\% de álcali ativo.

A análise de álcali ativo dentro de clone revelou diferenças significativas quando da comparação das cargas de 12,5\% e 14,5\% de álcali ativo. Conforme pode ser notado, a elevação do teor de sólidos solúveis com o aumento da carga de álcali ativo foi mais pronunciada para o clone G-31, podendo ser atribuído ao maior teor de extrativos, lignina e polissacarídeos degradados desta madeira.

O teor de sólidos do licor aumentou significativamente com a elevação dos níveis de álcali ativo, como mostra a figura 10. Este resultado era esperado, devido a maior quantidade de constituintes químicos do próprio licor de polpação (material inorgânico) e também aos materiais orgânicos dissolvidos no licor preto provenientes da solubilização de polissacarídeos e lignina da madeira.

O teor de sólidos solúveis (TSS) é um parâmetro importante e expressa a quantidade de material destinado à queima na caldeira de recuperação. Em geral, as empresas possuem como limite de produção a capacidade de queima de sólidos da caldeira de recuperação. Assim sendo, quanto maior o TSS no licor, menor a vazão que a caldeira poderá receber de licor para ser queimado, muitas vezes limitando a capacidade de produção de celulose. O fator que exerceu maior reflexo no teor de sólidos solúveis foi o álcali ativo. 


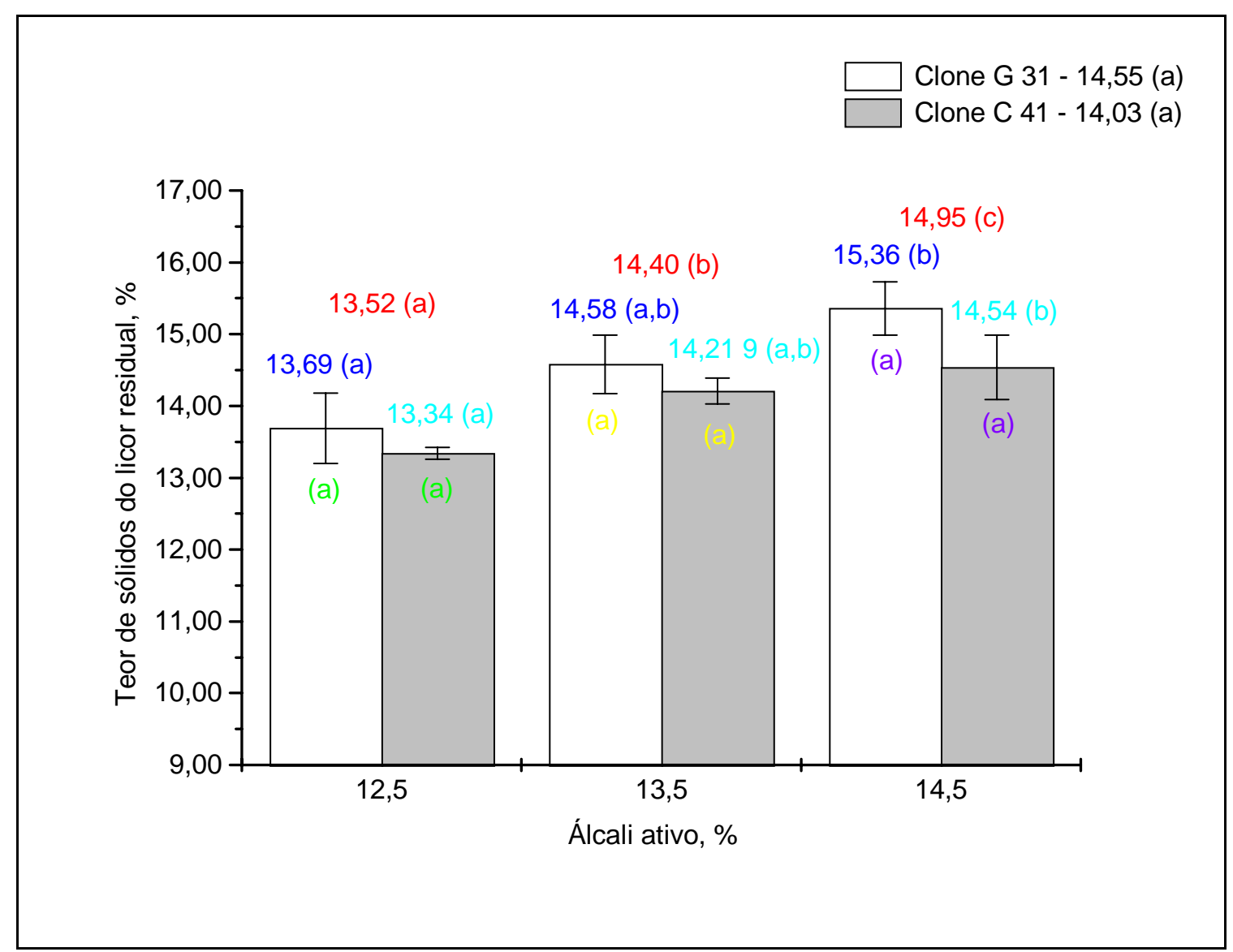

Figura 10 - Teor de sólidos do licor residual das polpações Kraft

A Figura 11 mostra a densidade do licor residual das polpações Kraft. A análise de variância geral mostrou efeito significativo, somente, para álcali ativo na densidade do licor residual. A análise de variância de álcali ativo dentro de clone foi significativa, em ordem decrescente, para o clone G-31 e clone C-41. A análise de variância de clone dentro de álcali ativo não foi significativa para $12,5 \%, 13,5 \%$ e $14,5 \%$ de álcali ativo. 


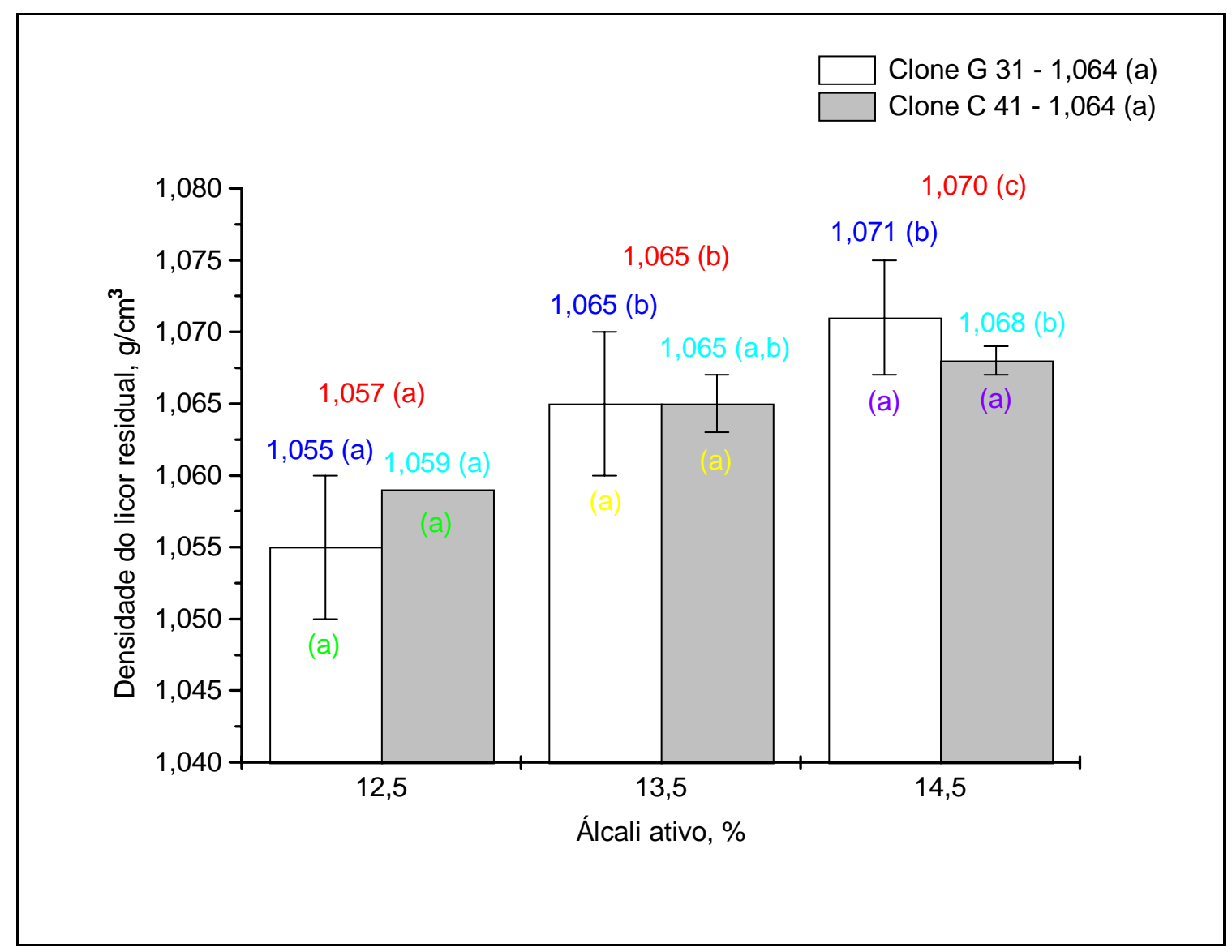

Figura 11 - Densidade do licor residual das polpações Kraft

A análise de álcali ativo dentro de clone foi mais pronunciada para o clone G-31, em relação ao clone C-41 podendo ser atribuído ao maior teor de extrativos, lignina e polissacarídeos degradados desta madeira. O fator que teve maior influência na densidade do licor residual foi o álcali ativo.

A Figura 12 mostra o álcali ativo do licor residual das polpações Kraft. A análise de variância geral mostrou efeito significativo, em ordem decrescente, para álcali ativo e clone no álcali ativo do licor residual. A análise de variância de álcali ativo dentro de clone foi significativa, em ordem decrescente, para o clone C-41 e clone G-31. A análise de variância de clone dentro de álcali ativo não foi significativa para $12,5 \%, 13,5 \%$ e $14,5 \%$ de álcali ativo. 


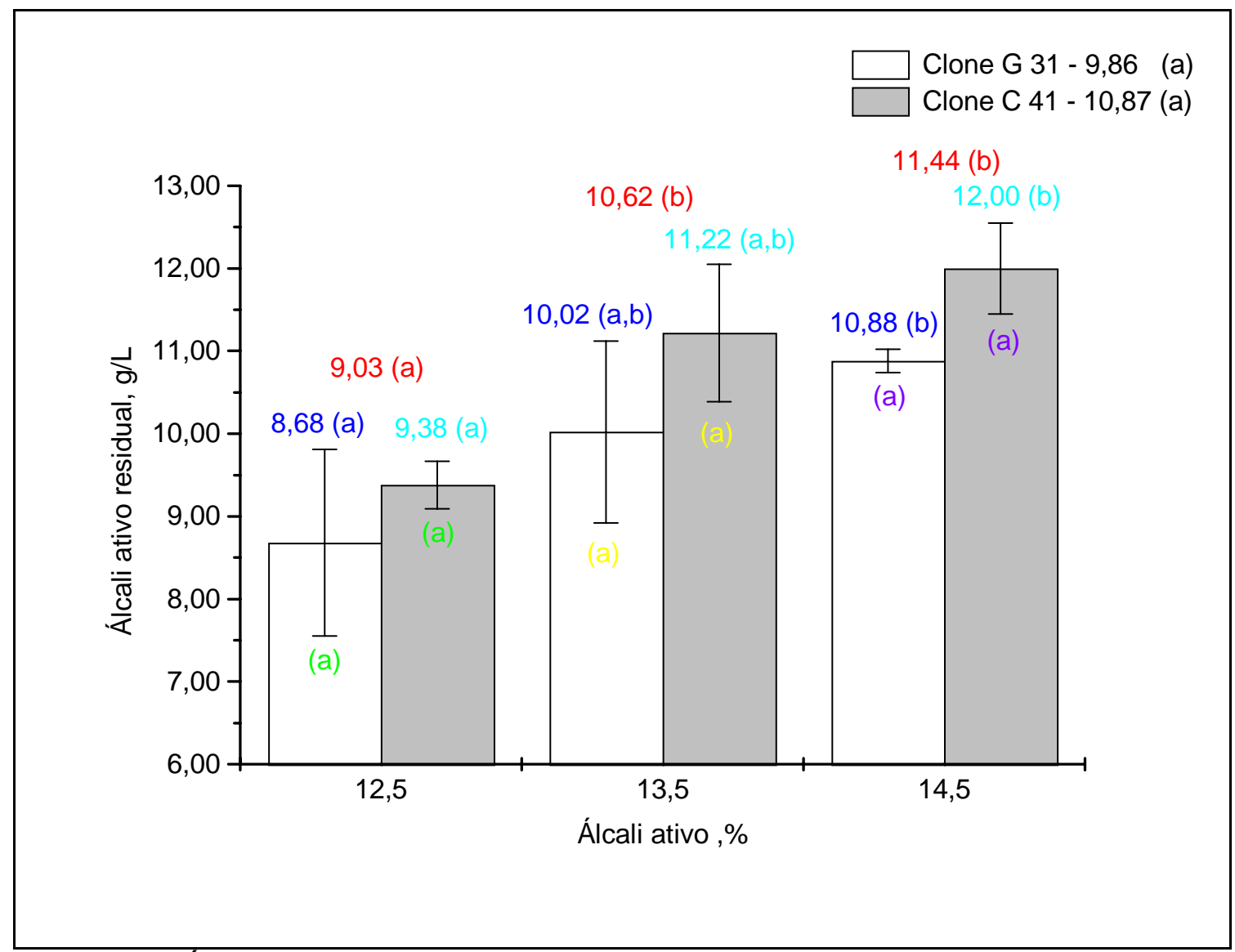

Figura 12 - Álcali ativo do licor residual das polpações Kraft

Os resultados do Teste de Tukey mostram que a análise de álcali ativo dentro de clone revelou diferenças significativas quando da comparação das cargas de $12,5 \%$ e $14,5 \%$ de álcali ativo. Conforme pode ser notado, a elevação do álcali ativo residual com o aumento da carga de álcali ativo foi mais pronunciada para o clone C-41 em relação ao clone G-31. O fator mais considerável no álcali ativo do licor residual foi a carga de álcali ativo.

A Figura 13 mostra o álcali efetivo do licor residual das polpações Kraft. A análise de variância geral mostrou efeito significativo, em ordem decrescente, para álcali ativo e clone no álcali efetivo do licor residual. A análise de variância de álcali ativo dentro de clone foi significativa, em ordem decrescente, para o 
clone G-31 e clone C-41. A análise de variância de clone dentro de álcali ativo não foi significativa para 12,5\%, 13,5\% e 14,5\% de álcali ativo.

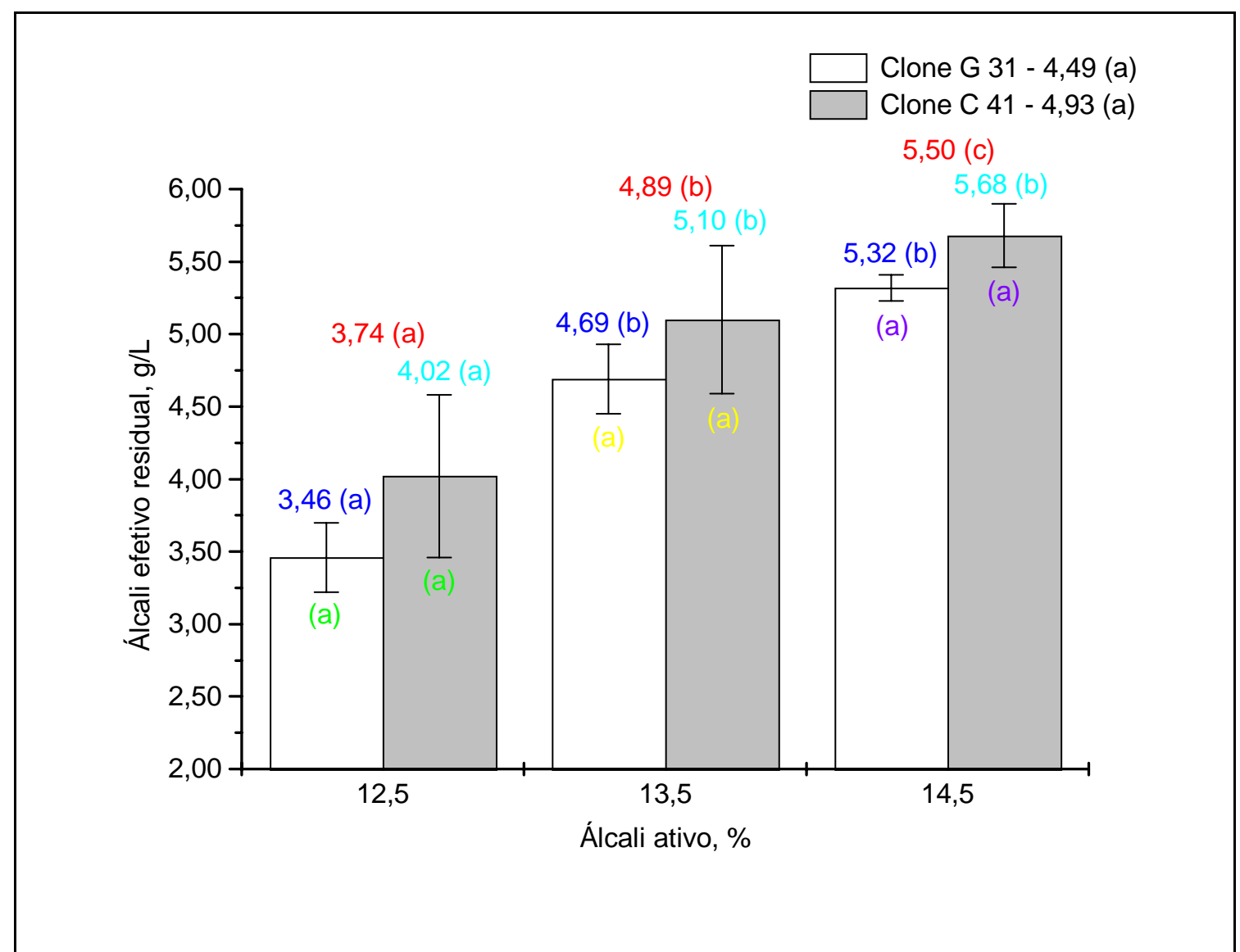

Figura 13 - Álcali efetivo do licor residual das polpações Kraft

Os resultados obtidos através do Teste de Tukey mostram que a análise de álcali ativo dentro de clone revelou diferenças significativas quando da comparação das cargas de 12,5\% e 13,5\% de álcali ativo. Conforme pode ser notado, a elevação do álcali efetivo residual com o aumento da carga de álcali ativo foi mais pronunciada para o clone G-31 em relação ao clone C-41. O fator mais importante no álcali efetivo do licor residual foi a carga de álcali ativo.

As Figuras 12 e 13 em conjunto mostram que o álcali ativo residual e álcali efetivo residual dentro de clone se elevaram com o aumento da carga de 
álcali ativo. O efeito para álcali ativo residual foi mais significativo para o clone C-41 e para álcali efetivo residual foi mais significativo para o clone G-31. Isto demonstra que os clones consumiram diferentes quantidades de íons $\mathrm{OH}^{-}$e $\mathrm{SH}^{-}$ na polpação. Para provar esta afirmação, a concentração de $\mathrm{Na}_{2} \mathrm{~S}$ no licor residual pode ser calculada pela fórmula: $A A=A E /\left(1-\mathrm{Na}_{2} \mathrm{~S} / 2\right)$, a qual pode ser facilmente deduzida considerando as definições de álcali ativo (AA), álcali efetivo (AE) e sulfidez (S). A obtenção da concentração de $\mathrm{Na}_{2} \mathrm{~S}$, desta forma, permite o cálculo da sulfidez nos licores residuais. O clone G-31 caracterizou por apresentar as seguintes sulfidez nos licores residuais em cargas de álcali ativo de $12,5 \%, 13,5 \%$ e $14,5 \%$, respectivamente: $13,9 \%, 10,6 \%$ e $9,4 \%$. O clone C41 apresentou as seguintes sulfidez nos licores residuais em cargas de álcali ativo de $12,5 \%, 13,5 \%$ e 14,5\%, respectivamente: 12,2\%, 9,7\% e 8,8\%. Estes cálculos mostram e explicam vários comportamentos diferentes em relação aos fatores clones e álcali ativo. O clone G-31 sempre consumiu mais íon $\mathrm{OH}^{-}$nos diversos níveis de álcali ativo que o clone C-41 e pode ser atribuído ao maior teor de extrativos na madeira, maior teor de lignina solúvel na madeira, facilidade de fenômenos de transporte devido a menor densidade, maior poder nucleofílico do íon $\mathrm{OH}^{-}$e neutralização dos grupos ácidos da degradação dos polissacarídeos. A análise da elevação de álcali ativo dentro de clone produziu licor residual com menor sulfidez, ou seja, em alta carga de álcali a madeira consome mais $\mathrm{Na}_{2} \mathrm{~S}$ que em baixa carga de álcali. A provável explicação é a maior nucleofilicidade do íon $\mathrm{HS}^{-}$em maiores cargas de álcali ativo. Este efeito foi maior para o clone G-31 que para o clone C-41 (a diferença da sulfidez no licor residual do clone G-31 em álcali ativo 12,5\% e 14,5\%=13,9-9,4 = 4,5\% e para o clone C-41 = 12,2 - 8,8 =3,4\%).

A Figura 14 mostra o álcali total do licor residual das polpações Kraft. A análise de variância geral mostrou efeito significativo, somente, para álcali ativo. A análise de variância de álcali ativo dentro de clone foi significativa, em ordem decrescente, para o clone G-31 e clone C-41. A análise de variância de clone 
dentro de álcali ativo não foi significativa para 12,5\%, 13,5\% e 14,5\% de álcali ativo.

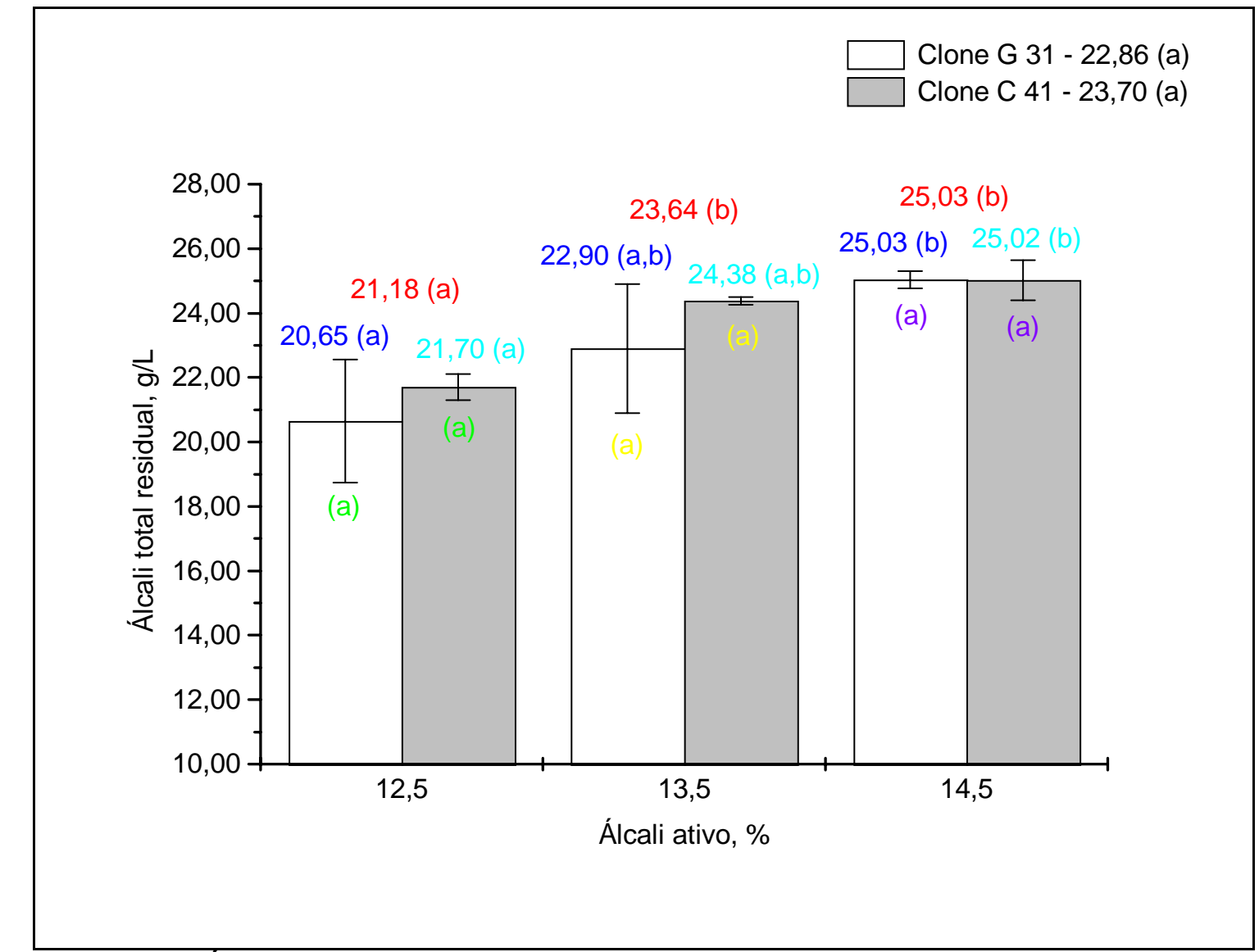

Figura 14 - Álcali total do licor residual das polpações Kraft

O Teste de Tukey mostra que a análise de álcali ativo dentro de clone revelou diferenças significativas quando da comparação das cargas de 12,5\% e 14,5\% de álcali ativo. Conforme pode ser notado, a elevação do álcali total residual com o aumento da carga de álcali ativo foi mais pronunciada para o clone G-31 em relação ao clone C-41. O fator que exerceu maior influência no álcali total do licor residual foi a carga de álcali ativo.

A Figura 15 mostra o álcali ativo consumido base madeira das polpações Kraft. A análise de variância geral mostrou efeito significativo, em ordem 
decrescente, para clone, álcali ativo e interação clone $x$ álcali ativo no álcali ativo consumido base madeira. A interação significativa indica que o comportamento dos clones depende das cargas de álcali ativo. Neste caso, as médias gerais não podem ser comparadas. A análise de variância de álcali ativo dentro de clone foi significativa, em ordem decrescente, para o clone G-31 e clone C-41. A análise de variância de clone dentro de álcali ativo foi significativa, somente, para $13,5 \%$ de álcali ativo.

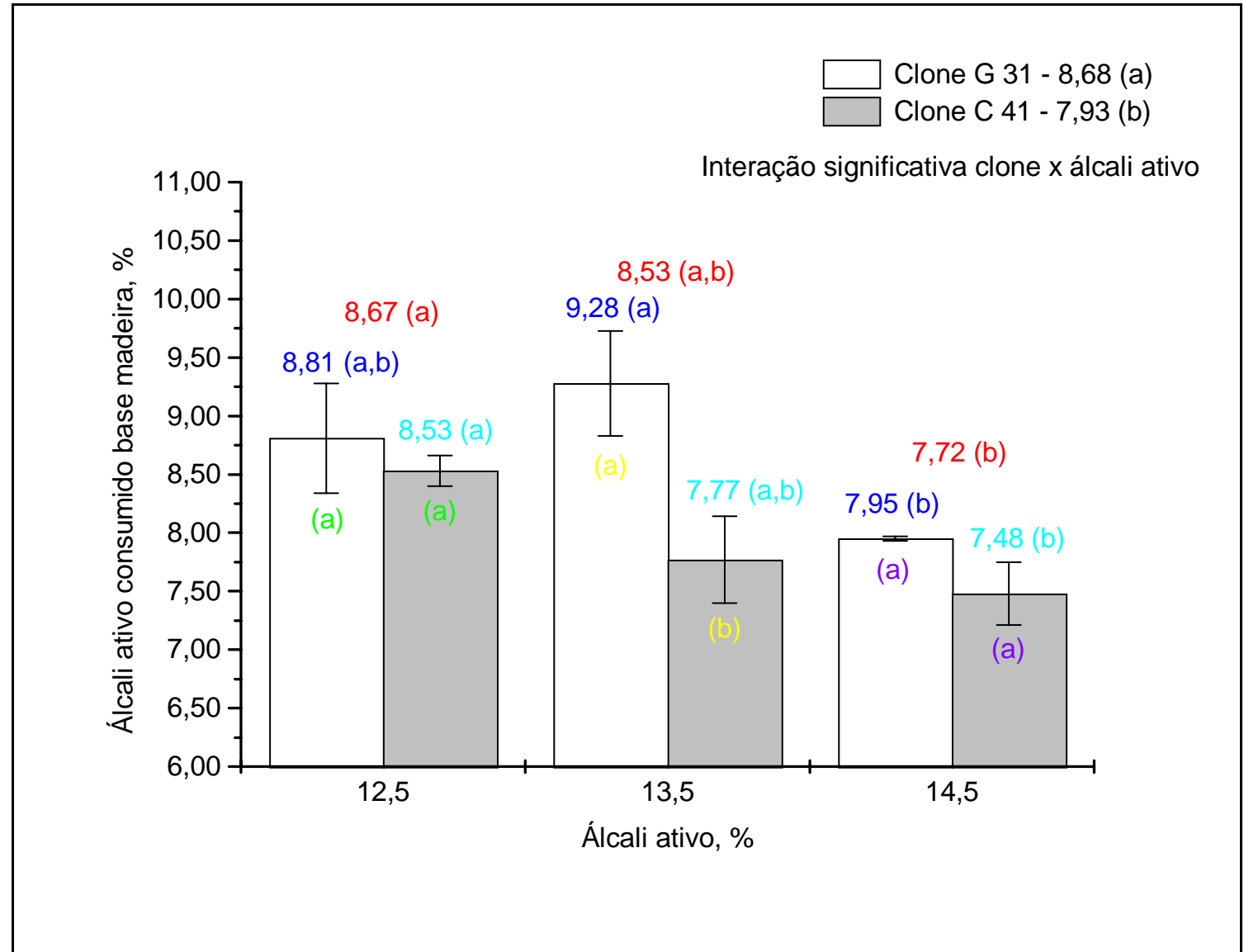

Figura 15 - Álcali ativo consumido base madeira das polpações Kraft

Conforme pode ser observado na Figura 15, os resultados do Teste de Tukey mostram que a análise de clone dentro de álcali ativo mostrou comportamento diferenciado. O clone G-31 consumiu maior carga de álcali ativo 
base madeira que o clone C-41 em 13,5\% de álcali ativo. Nas cargas de 12,5\% e $14,5 \%$ de álcali ativo, os álcalis ativos consumidos para os dois clones foram iguais. Este comportamento diferenciado dos clones nas cargas de álcali ativo foi detectado como interação significativa clone $x$ álcali ativo na análise de variância geral.

A análise de clone dentro de álcali revela comportamento diferenciado, pois o decréscimo no consumo de álcali ativo base madeira do clone G-31 foi maior em relação ao clone C-41 nas cargas de 13,5\% e 14,5\% de álcali ativo. Os fatores mais influentes no consumo de álcali ativo base produto químico, em ordem decrescente, foram clone, álcali ativo e interação clone x álcali ativo.

A Figura 16 mostra o álcali ativo consumido base produto químico das polpações Kraft. A análise de variância geral mostrou efeito significativo, em ordem decrescente, para álcali ativo, clone e interação clone $\mathrm{x}$ álcali ativo no álcali ativo consumido base produto químico. A interação significativa indica que o comportamento dos clones depende das cargas de álcali ativo. Neste caso, as médias gerais não podem ser comparadas. A análise de variância de álcali ativo dentro de clone foi significativa, em ordem decrescente, para o clone G-31 e clone C-41. A análise de variância de clone dentro de álcali ativo foi significativa, somente, para $13,5 \%$ de álcali ativo. 


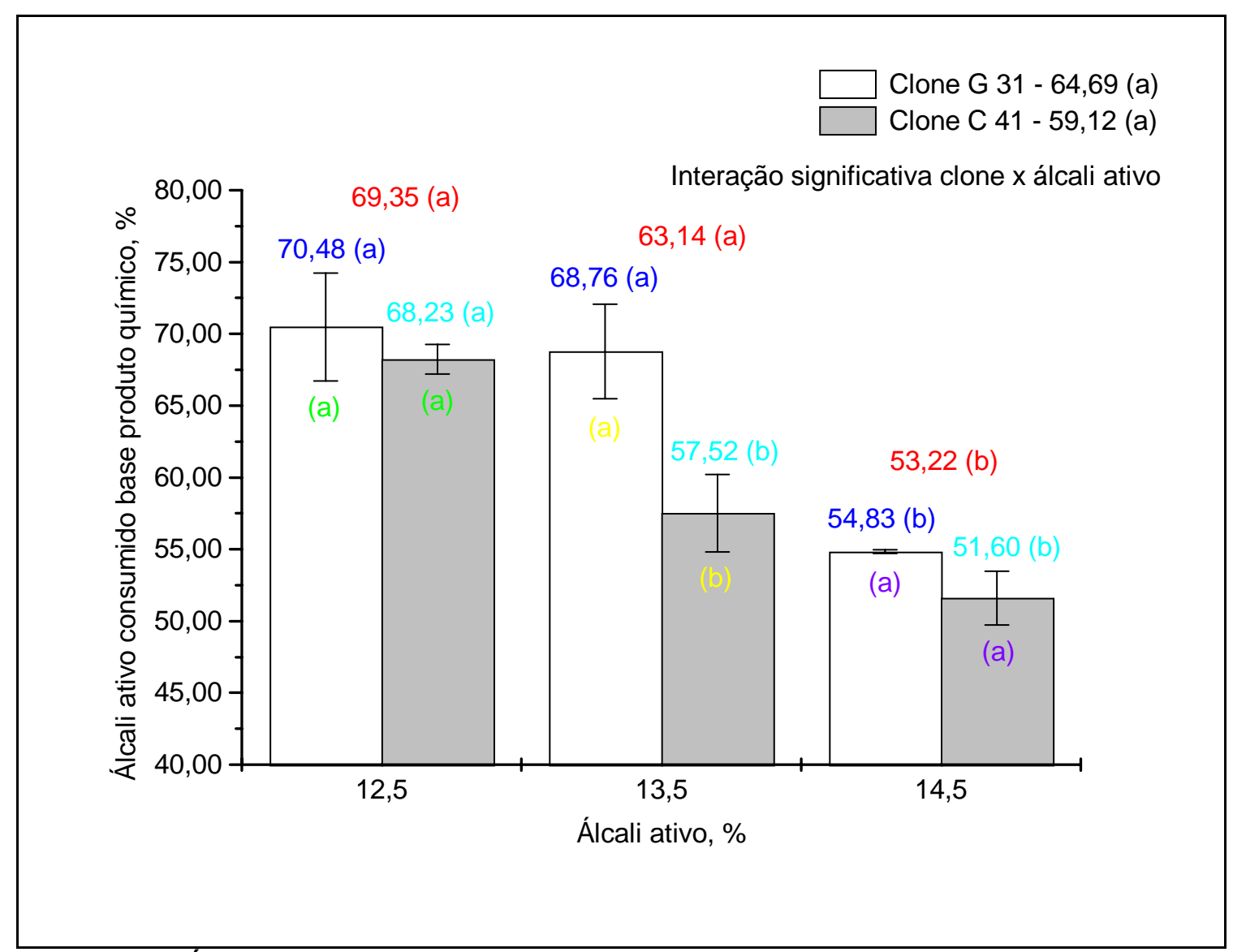

Figura 16 - Álcali ativo consumido base produto químico das polpações Kraft

O Teste de Tukey mostrou que a análise de clone dentro de álcali ativo mostrou comportamento diferenciado. O clone G-31 consumiu maior carga de álcali ativo base produto químico que o clone C-41 em 13,5\% de álcali ativo. Nas cargas de 12,5\% e 14,5\% de álcali ativo, os álcalis ativos consumidos para os dois clones foram iguais. Este comportamento diferenciado dos clones nas cargas de álcali ativo foi detectado como interação significativa clone $\mathrm{x}$ álcali ativo na análise de variância geral. A análise de álcali ativo dentro de clone revela comportamento diferenciado, pois o decréscimo no consumo de álcali ativo consumido base produto químico do clone G-31 foi maior em relação ao clone C-41 nas cargas de álcali ativo utilizadas. Os fatores mais importantes no 
consumo de álcali ativo base produto químico, em ordem decrescente, foram álcali ativo, clone e interação clone x álcali ativo.

\subsection{Branqueamento das polpas}

A pré-deslignificação com oxigênio e o branqueamento das polpas dos dois clones (G-31 e C-41), nos três níveis de álcali ativo (12,5\%, 13,5\% e $14,5 \%$ ), foram analisados quanto à eficiência na pré- $\mathrm{O}_{2}$, número kappa (após pré- $\mathrm{O}_{2}$, após $\mathrm{D}_{\mathrm{o}}$ e após $\mathrm{E}_{\mathrm{OP}}$ ), viscosidade intrínseca (após pré- $\mathrm{O}_{2}$, após $\mathrm{D}_{0}$, após EOP e após $D_{1}$ ) e alvura após $D_{1}$.

A Figura 17 mostra a eficiência na pré-deslignificação com oxigênio. A análise de variância geral mostrou efeito significativo, em ordem decrescente, para álcali ativo, clone e interação clone x álcali ativo na eficiência da prédeslignificação com oxigênio. A interação significativa indica que 0 comportamento dos clones depende das cargas de álcali ativo. Neste caso, as médias gerais não podem ser comparadas. A análise de variância de álcali ativo dentro de clone foi significativa, em ordem decrescente, para o clone C-41 e clone G-31. A análise de variância de clone dentro de álcali ativo foi significativa, somente, para $14,5 \%$ de álcali ativo.

Conforme pode ser notado na Figura 17, o Teste de Tukey mostrou que a análise de clone dentro de álcali ativo revelou comportamento diferenciado. Os clones G-31 e C-41 apresentaram médias iguais, estatisticamente, nas cargas de 12,5\% e 13,5\% de álcali ativo. Entretanto, na carga de 14,5\% de álcali ativo, a eficiência na pré-deslignificação com oxigênio do clone G-31 foi significativamente superior quando comparada com o clone C-41. Este comportamento diferenciado dos clones nas cargas de álcali ativo foi detectado como interação significativa clone $\mathrm{x}$ álcali ativo na análise de variância geral.

A análise de álcali ativo dentro de clone revela comportamento diferente para os clones. A eficiência na pré-deslignificação com oxigênio em função do álcali ativo mostrou tendência de queda exponencial para o clone G-31 e linear 
para o clone C-41. Isto significa que o clone G-31 foi menos sensível a variação de álcali ativo que o clone C-41 em relação à eficiência na pré-deslignificação com oxigênio. É importante observar que a eficiência da deslignificação com oxigênio tende a ser maior em polpas não-branqueadas com maior número kappa (ver Figura 6). Conforme relatado na revisão de literatura, Silva (1997) concluiu que a eficiência da deslignificação com oxigênio mostrou-se maior para polpas de madeira de difícil deslignificação. Os teores mais elevados da lignina residual com anel aromático na forma fenólica e cadeia lateral com duplas ligações são os sítios preferidos do reagente eletrofílico oxigênio e, portanto, a alta eficiência. Singh citado por Salvador et al. (2001) relata que o oxigênio atua de preferência em estruturas fenólicas livres da lignina, provocando sua fragmentação, resultando, assim, em estruturas mais solúveis e de mais fácil remoção.

Os fatores mais importantes, em ordem decrescente, referentes à eficiência na pré-deslignificação com oxigênio foram álcali ativo, clone e interação entre eles. 


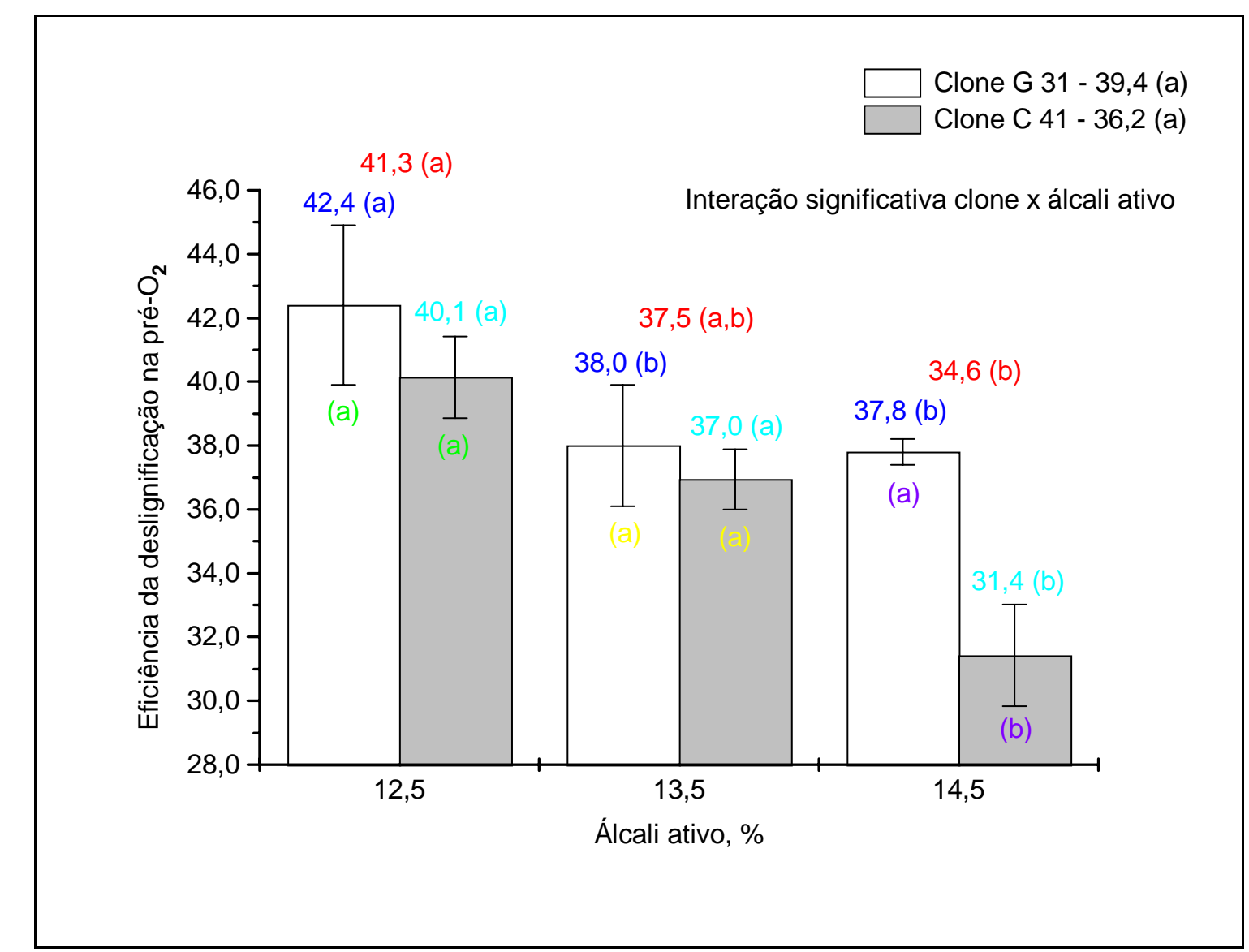

Figura 17 - Eficiência na pré-deslignificação com oxigênio

A Figura 18 refere-se ao número kappa após pré- $\mathrm{O}_{2}$. A análise de variância geral mostrou efeito significativo, em ordem decrescente, para álcali ativo e clone. A análise de variância de álcali ativo dentro de clone foi significativa, em ordem decrescente, para o clone C-41 e clone G-31. A análise de variância de clone dentro de álcali ativo foi significativa, em ordem decrescente, para $12,5 \%, 13,5 \%$ e $14,5 \%$ de álcali ativo. 


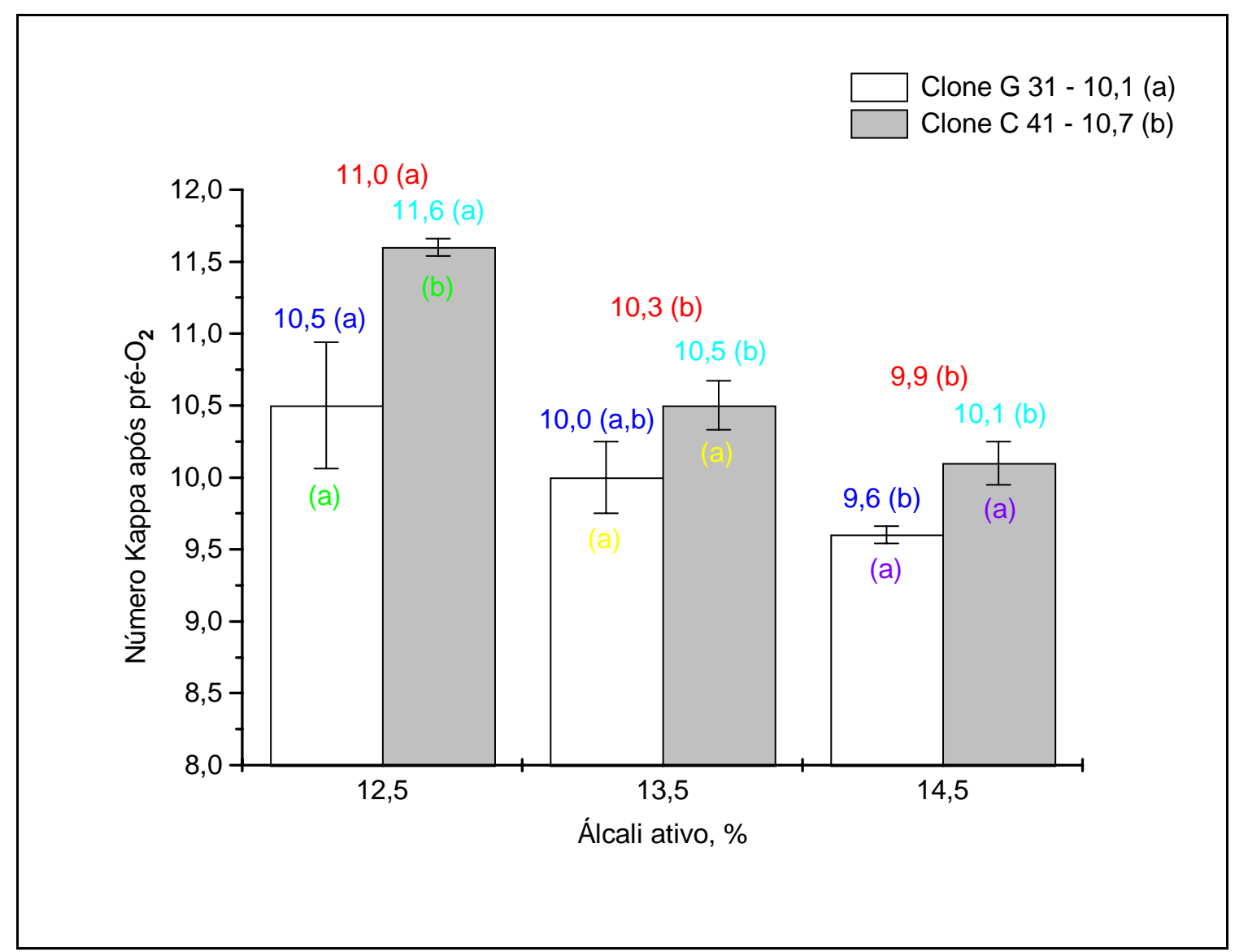

Figura 18 - Número kappa após pré-O $\mathrm{O}_{2}$

O Teste de Tukey mostrou que a análise de clone dentro de álcali ativo revelou maior número kappa após pré- $\mathrm{O}_{2}$ para o clone $\mathrm{C}-41$ sendo significativo, somente, para $12,5 \%$ de álcali ativo. Este resultado era esperado, haja vista a maior eficiência do clone G-31. A análise de álcali ativo dentro de clone mostra comportamentos distintos para os clones. A análise de variância revelou uma influência mais significativa para o clone C-41 em comparação com o clone G31, ou seja, maior decréscimo do número kappa no clone C-41.

Os resultados de número kappa da polpa não-branqueada (figura 6) mostraram valores relativamente diferentes para o clone G-31 (18,3 - 15,5) e após pré- $\mathrm{O}_{2}$ valores relativamente próximos $(10,5-9,6)$. O número kappa após polpação do clone C-41 $\left(19,3\right.$ - 14,7) e após pré-O ${ }_{2}(11,6$ - 10,1). Portanto, os 
números kappa das polpas não branqueadas tenderam a se igualarem após a pré- $\mathrm{O}_{2}$ e este comportamento pode ser atribuído a maior eficiência da prédeslignificação nas menores cargas de álcali ativo.

Os fatores que mais influenciaram no número kappa após pré- $\mathrm{O}_{2}$, em ordem decrescente, foram álcali ativo e clone.

A Figura 19 mostra a viscosidade intrínseca após pré- $\mathrm{O}_{2}$. A análise de variância geral mostrou efeito significativo, em ordem decrescente, para álcali ativo e interação clone $x$ álcali ativo na viscosidade intrínseca após pré- $\mathrm{O}_{2}$. A interação significativa indica que o comportamento dos clones depende das cargas de álcali ativo. Neste caso, as médias gerais não podem ser comparadas. A análise de variância de álcali ativo dentro de clone foi significativa, em ordem decrescente, para o clone C-41 e clone G-31. A análise de variância de clone dentro de álcali ativo foi significativa, somente, para 13,5\% de álcali ativo.

Conforme pôde ser observado na Figura 19, o Teste de Tukey mostrou que a análise de clone dentro de álcali ativo revelou comportamento diferenciado. Os clones G-31 e C-41 apresentaram médias iguais, estatisticamente, nas cargas de 12,5\% e 14,5\% de álcali ativo. Porém, na carga de $13,5 \%$ de álcali ativo, a viscosidade da celulose do clone C-41 foi significativamente superior quando comparada com o clone G-31. Este comportamento diferenciado dos clones nas cargas de álcali ativo foi detectado como interação significativa clone $x$ álcali ativo na análise de variância geral. $A$ análise de álcali ativo dentro de clone mostra comportamentos distintos para os clones. A análise de variância revelou uma influência mais significativa para o clone C-41 em comparação com o clone G-31, ou seja, maior decréscimo da viscosidade da celulose no clone C-41.

Os fatores mais influentes na viscosidade da celulose após pré- $\mathrm{O}_{2}$ foram álcali ativo e interação clone x álcali ativo. 


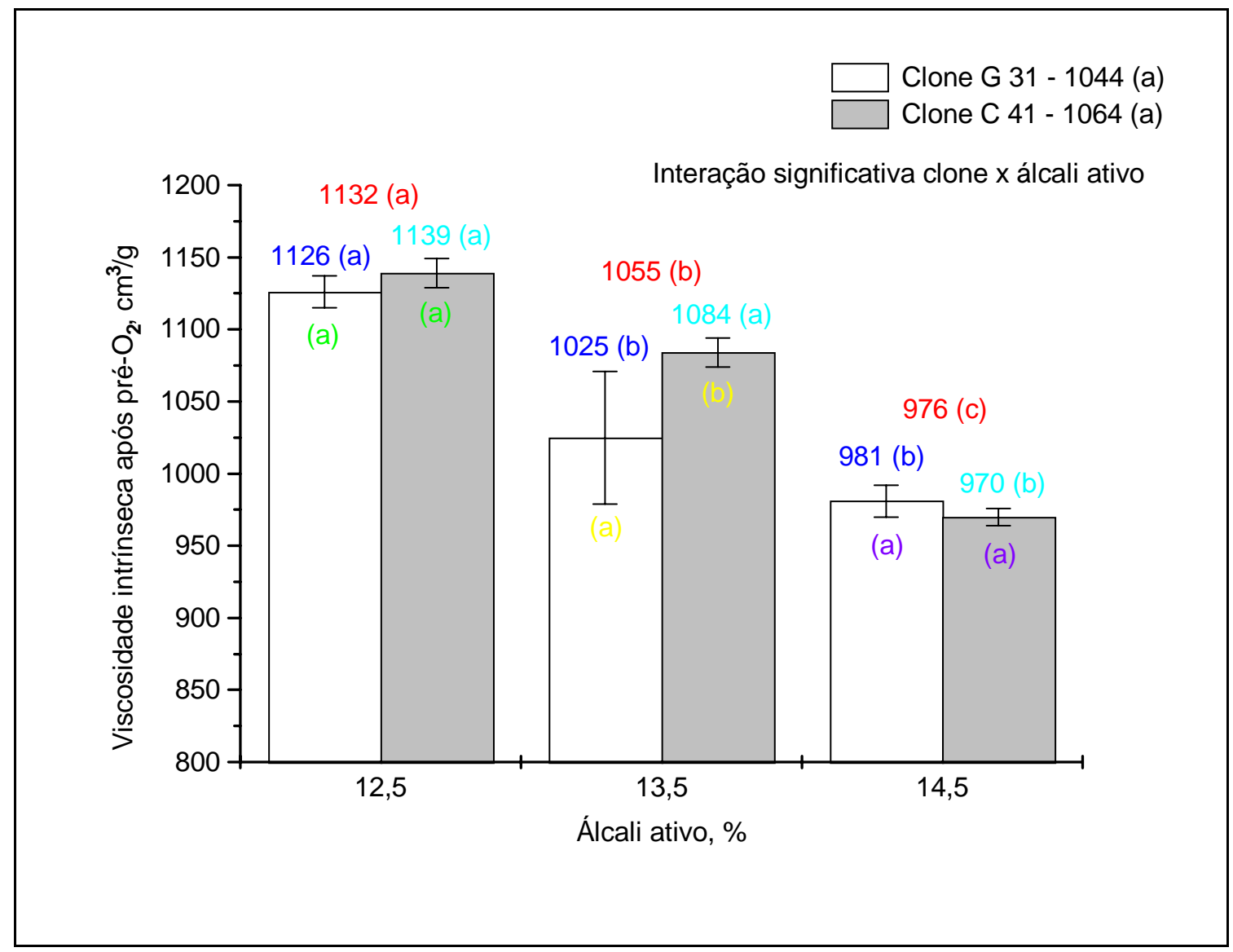

Figura 19 - Viscosidade intrínseca após pré- $\mathrm{O}_{2}$

A Figura 20 mostra o número kappa após o estágio $D_{0}$. A análise de variância geral mostrou efeito significativo, somente, para interação clone $\mathrm{x}$ álcali ativo no número kappa após o estágio $D_{0}$. A interação significativa indica que o comportamento dos clones depende das cargas de álcali ativo. Neste caso, as médias gerais não podem ser comparadas. A análise de variância de álcali ativo dentro de clone foi significativa, somente, para o clone C-41. A análise de variância de clone dentro de álcali ativo foi significativa, somente, para 14,5\% de álcali ativo.

Conforme mostrado na Figura 20, o Teste de Tukey mostrou que a análise de clone dentro de álcali ativo revelou comportamento diferenciado. $\mathrm{O}$ clone G-31 apresentou menor número kappa nas cargas de álcali ativo de 
12,5\% e 13,5\% e maior número kappa na carga de 14,5\% em comparação com o clone C-41, embora não apresentando diferenças significativas. Observe que este número kappa teve o mesmo comportamento que o número kappa após polpação Kraft (Figura 6). Porém, este comportamento diferenciado dos clones nas cargas de álcali ativo foi detectado como interação significativa clone $x$ álcali ativo na análise de variância geral. A análise de álcali ativo dentro de clone mostra comportamentos distintos para os clones. A análise de variância revelou uma influência mais significativa para o clone C-41 em comparação com o clone G-31. A visualização da Figura 20 permite observar que o número kappa se estabilizou nos valores 3,1 - 3,2 para o clone G-31, mas ainda não para o clone C-41.

O fator mais importante no número kappa após $D_{0}$ foi a interação clone $x$ álcali ativo. 


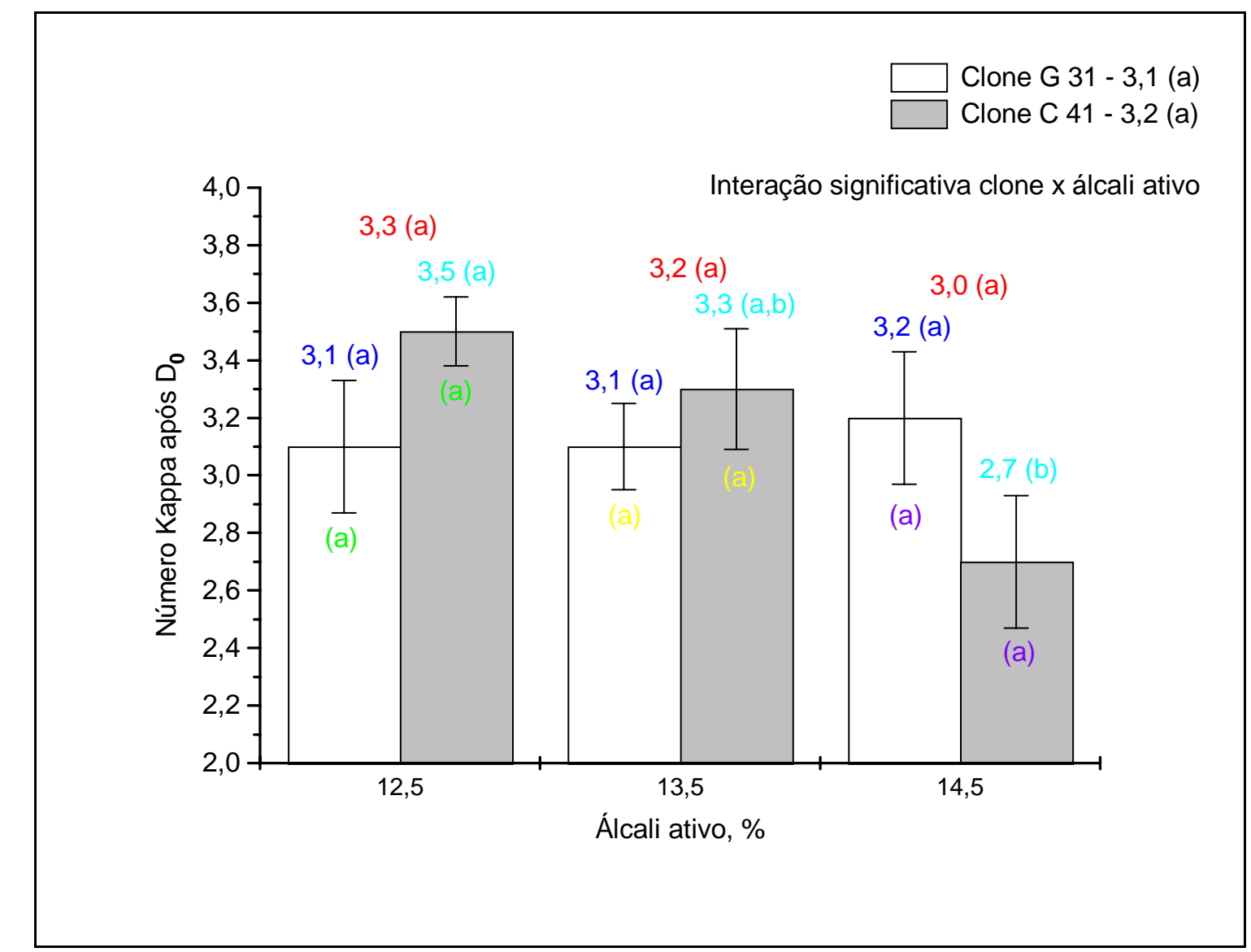

Figura 20 - Número kappa após o estágio $D_{0}$

A Figura 21 mostra a viscosidade intrínseca após o estágio $D_{0}$. $A$ análise de variância geral mostrou efeito significativo, em ordem decrescente, para álcali ativo, clone e interação clone $x$ álcali ativo na viscosidade intrínseca após o estágio $D_{0}$. A interação significativa indica que o comportamento dos clones depende das cargas de álcali ativo. Neste caso, as médias gerais não podem ser comparadas. A análise de variância de álcali ativo dentro de clone foi significativa, em ordem decrescente, para o clone G-31 e clone C-41. A análise de variância de clone dentro de álcali ativo foi significativa, em ordem decrescente, para $13,5 \%$ e $14,5 \%$ de álcali ativo. 


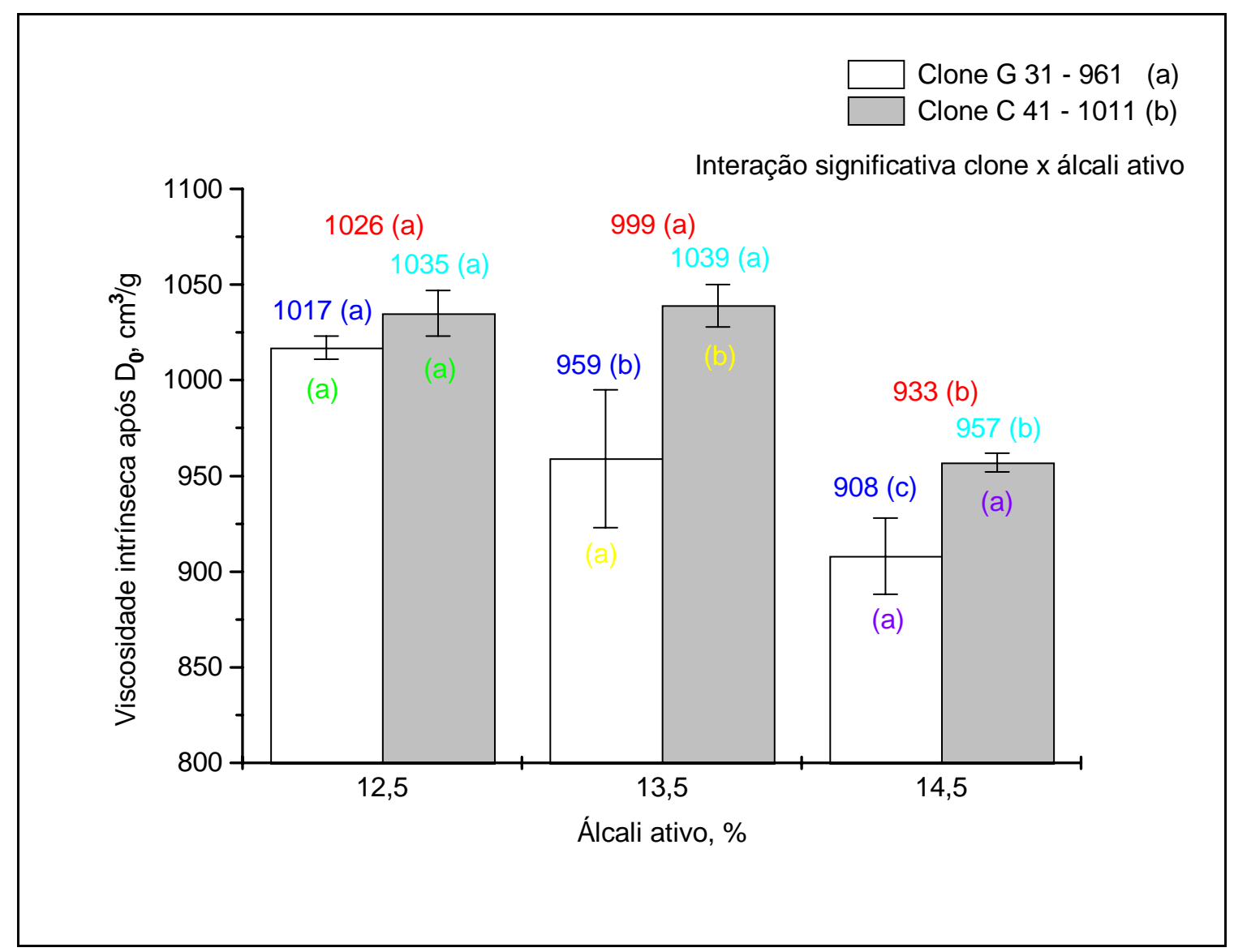

Figura 21 - Viscosidade intrínseca após o estágio $D_{0}$

Conforme poder ser observado na Figura 21, o Teste de Tukey mostrou que a análise de clone dentro de álcali ativo mostrou comportamento diferenciado. Os clones G-31 e C-41 apresentaram médias iguais, estatisticamente, nas cargas de 12,5\% e 14,5\% de álcali ativo. Porém, na carga de $13,5 \%$ de álcali ativo, a viscosidade da celulose do clone C-41 foi significativamente superior quando comparada com o clone G-31. Este comportamento diferenciado dos clones nas cargas de álcali ativo foi detectado como interação significativa clone $x$ álcali ativo na análise de variância geral. A análise de álcali ativo dentro de clone mostra comportamentos distintos para os clones. A análise de variância revelou uma influência mais significativa para o 
clone G-31 em comparação com o clone C-41, ou seja, maior decréscimo da viscosidade da celulose no clone G-31.

Os fatores mais influentes na viscosidade da celulose após $D_{0}$ foram, em ordem decrescente, álcali ativo, clone e interação clone $x$ álcali ativo.

A Figura 22 mostra o número kappa após o estágio $E_{O P}$. A análise de variância geral não mostrou efeito significativo para clone, álcali e interação clone $x$ álcali ativo no número kappa após o estágio $E_{O P}$. A análise de variância de álcali ativo dentro de clone não foi significativa para o clone G-31 e clone C41. A análise de variância de clone dentro de álcali ativo não foi significativa para $12,5 \%, 13,5 \%$ e $14,5 \%$ de álcali ativo.

Os fatores álcali ativo, clone e interação clone $x$ álcali ativo não exerceram mais nenhuma influência no número kappa após o estágio $\mathrm{E}_{\mathrm{OP}}$. 


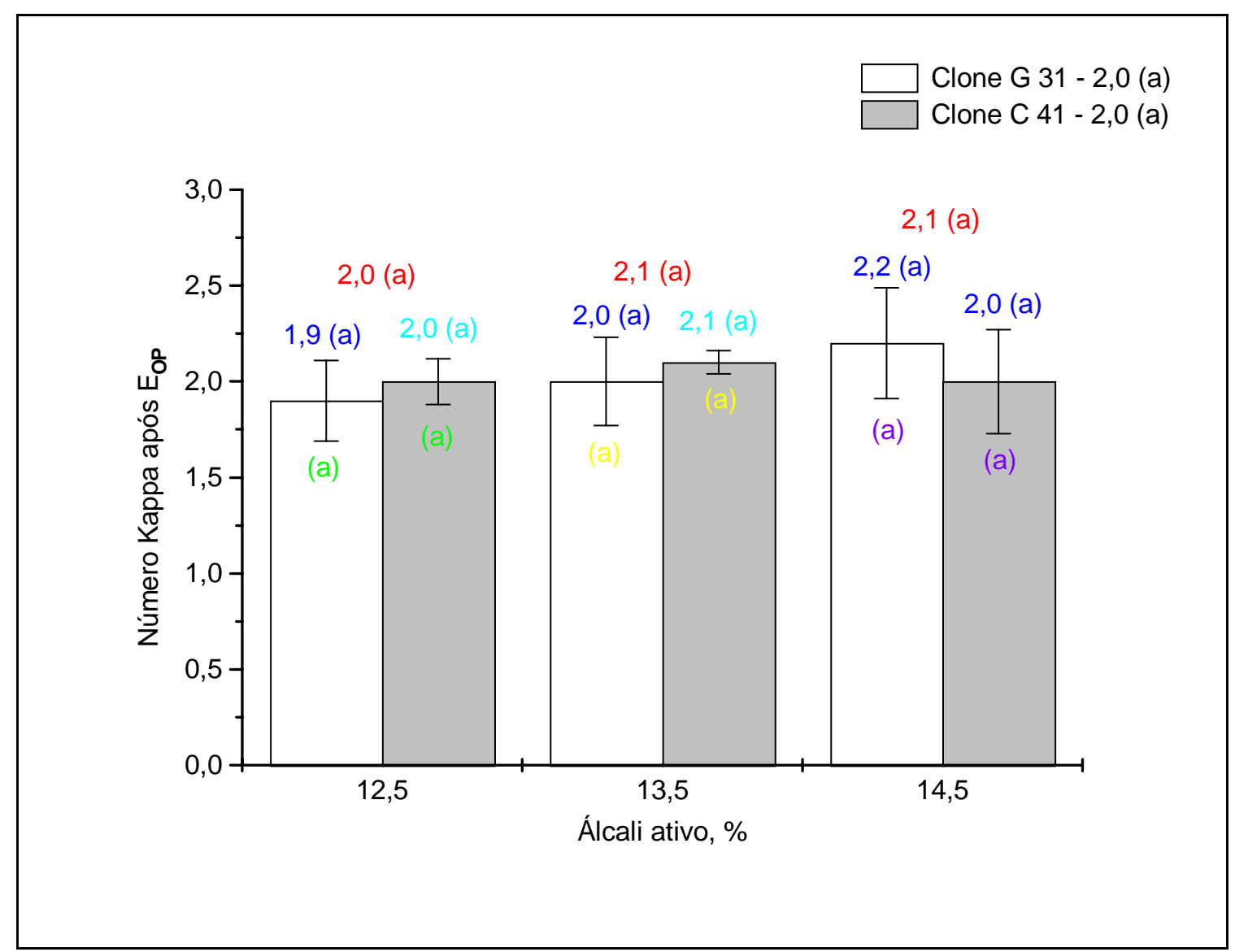

Figura 22 - Número kappa após o estágio $\mathrm{E}_{\mathrm{OP}}$

A Figura 23 mostra a viscosidade intrínseca após Eop. A análise de variância geral mostrou efeito significativo, em ordem decrescente, para álcali ativo e clone na viscosidade intrínseca após $E_{O P}$. A análise de variância de álcali ativo dentro de clone foi significativa, em ordem decrescente, para o clone G-31 e clone C-41. A análise de variância de clone dentro de álcali ativo foi significativa, em ordem decrescente, para 13,5\% e 14,5\% de álcali ativo.

Os resultados do Teste de Tukey mostraram que a análise de clone dentro de álcali ativo mostrou maior viscosidade intrínseca após EOP para o clone C-41 sendo significativo, somente, para 13,5\% de álcali ativo. A análise de álcali ativo dentro de clone mostra comportamentos distintos para os clones. A análise de variância revelou uma influência mais significativa para o clone G-31 
em comparação com o clone C-41, ou seja, maior decréscimo da viscosidade intrínseca após E $\mathrm{OP}_{\mathrm{P}}$ no clone G-31.

Os fatores mais influentes na viscosidade da celulose após $E_{O P}$ foram, em ordem decrescente, álcali ativo e clone.

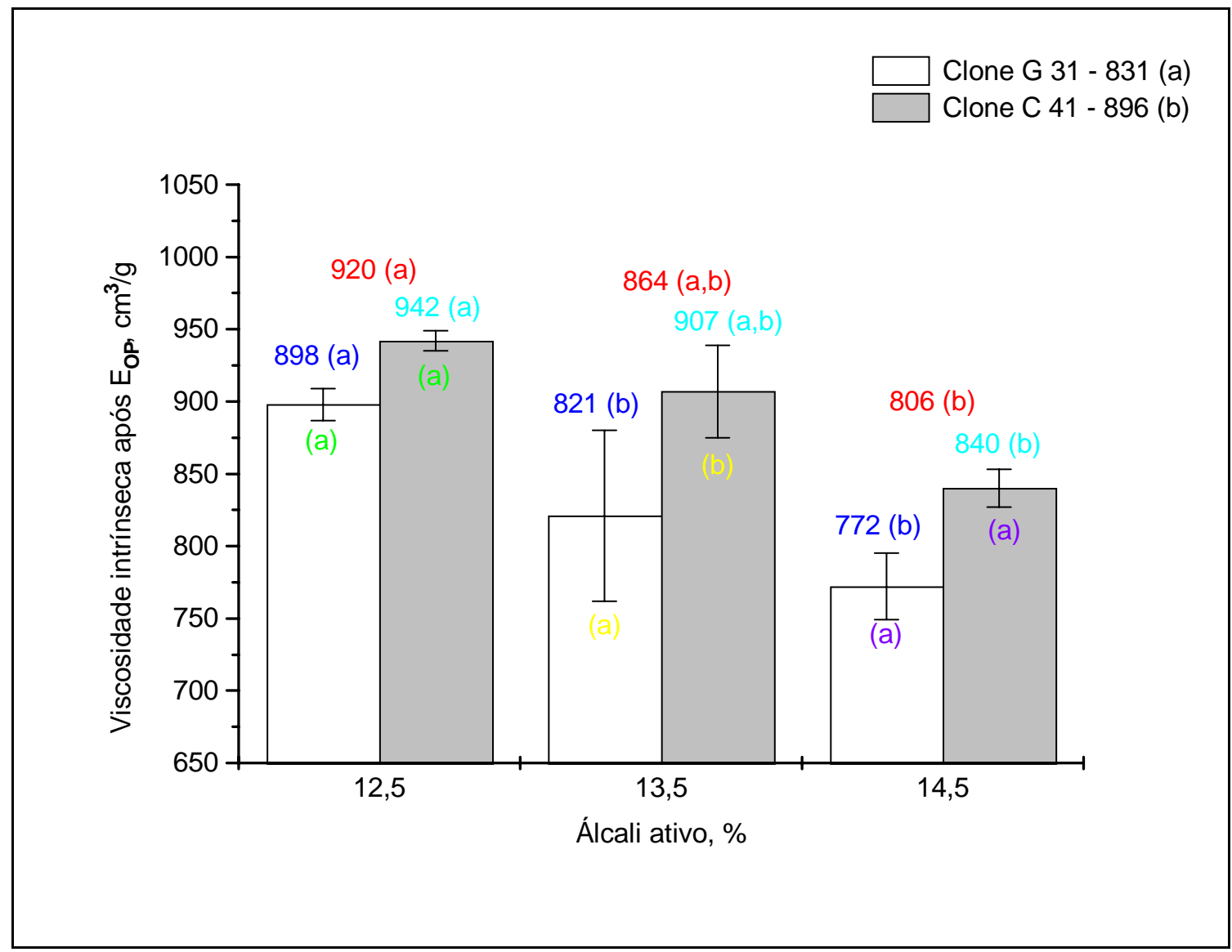

Figura 23 - Viscosidade intrínseca após EOP

A Figura 24 mostra a viscosidade intrínseca após $D_{1}$. A análise de variância geral mostrou efeito significativo, em ordem decrescente, para clone e álcali ativo na viscosidade intrínseca após $D_{1}$. $A$ análise de variância de álcali ativo dentro de clone foi significativa, em ordem decrescente, para o clone C-41 e clone G-31. A análise de variância de clone dentro de álcali ativo foi significativa, em ordem decrescente, para 12,5\%, 13,5\% e 14,5\% de álcali ativo. 
Os resultados do Teste de Tukey revelaram que a análise de clone dentro de álcali ativo mostrou maior viscosidade intrínseca após $D_{1}$ para o clone C-41 sendo significativo para $12,5 \%$ e $13,5 \%$ de álcali ativo. A análise de álcali ativo dentro de clone mostra comportamentos distintos para os clones. A análise de variância revelou uma influência mais significativa para o clone C-41 em comparação com o clone G-31, ou seja, maior decréscimo da viscosidade intrínseca após $D_{1}$ no clone C-41.

Os fatores mais influentes na viscosidade da celulose após $D_{1}$ foram, em ordem decrescente, clone e álcali ativo.

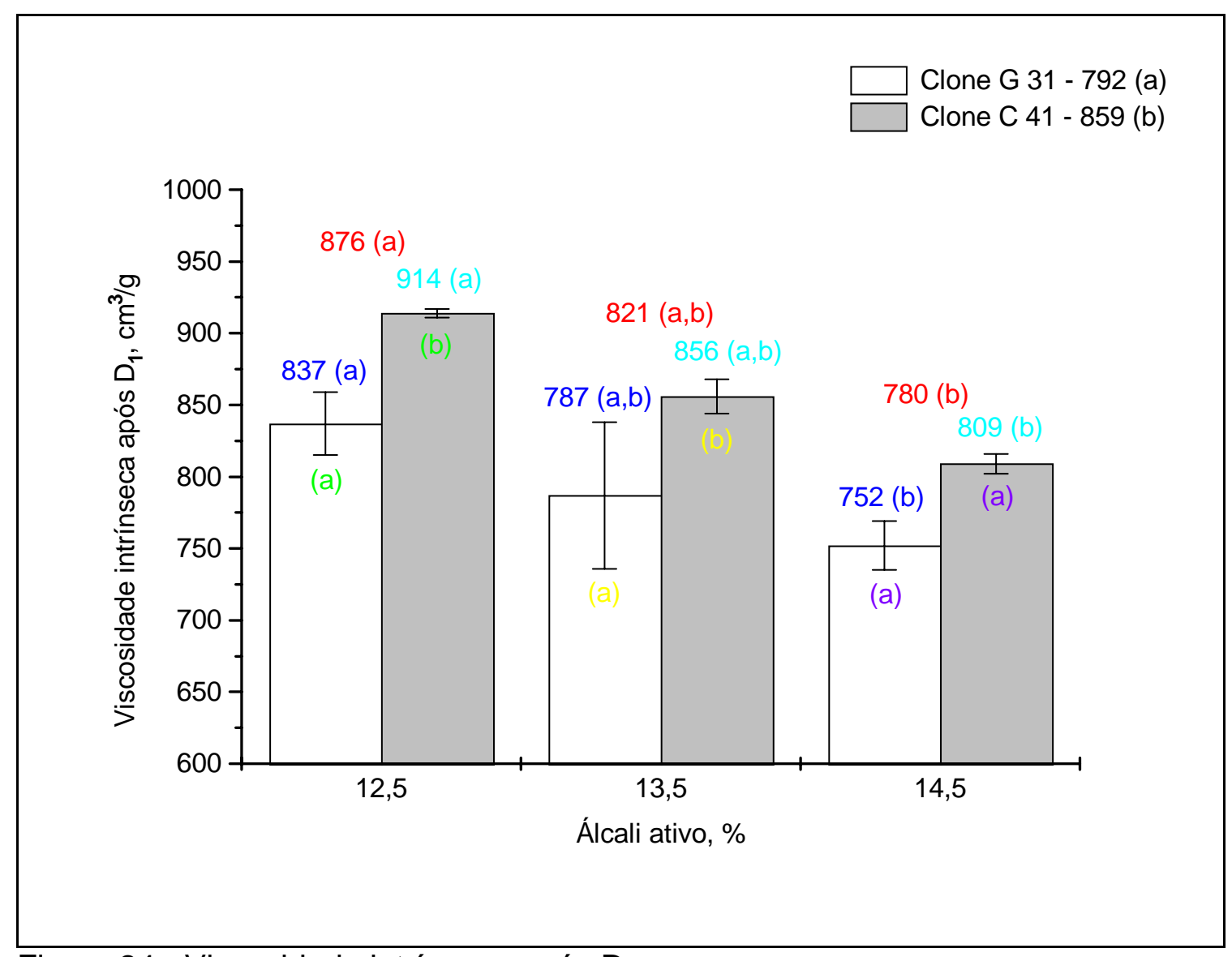

Figura 24 - Viscosidade intrínseca após $D_{1}$ 
A Figura 25 mostra a alvura final após $D_{1}$. A análise de variância geral mostrou efeito significativo, em ordem decrescente, para interação clone $x$ álcali ativo, clone e álcali ativo na alvura após $D_{1}$. A interação significativa indica que o comportamento dos clones depende das cargas de álcali ativo. Neste caso, as médias gerais não podem ser comparadas. A análise de variância de álcali ativo dentro de clone foi significativa, em ordem decrescente, para o clone C-41 e clone G-31. A análise de variância de clone dentro de álcali ativo foi significativa, em ordem decrescente para 14,5\%, 12,5\% e 13,5\% de álcali ativo.

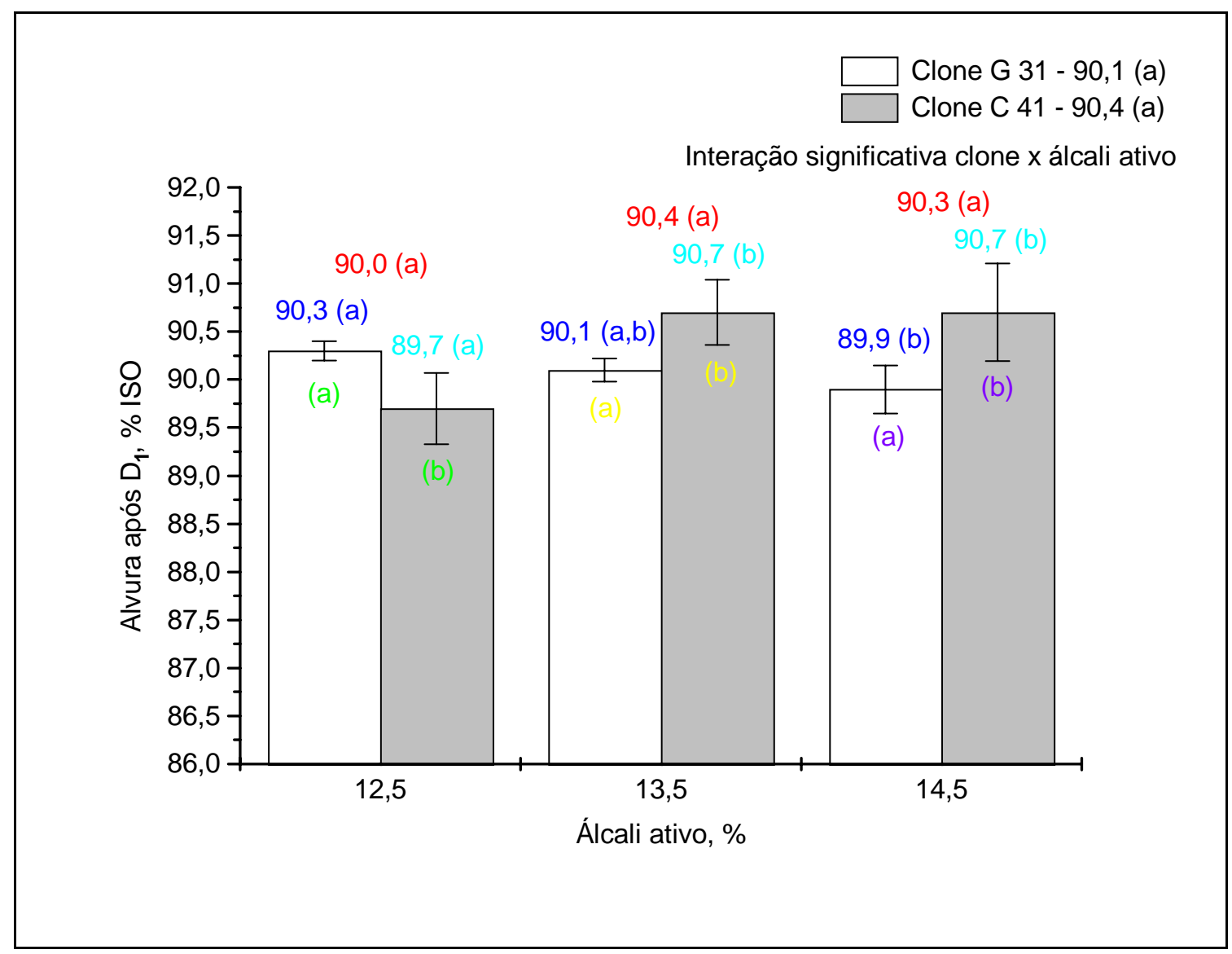

Figura 25 - Alvura após $\mathrm{D}_{1}$

Conforme poder ser notado na Figura 25, a análise de clone dentro de álcali ativo mostrou comportamento diferenciado. A polpa do clone G-31 
apresentou maior alvura em $12,5 \%$ de álcali ativo e menor alvura em 13,5\% e $14,5 \%$ de álcali ativo quando comparada com a polpa do clone C-41. Este comportamento diferenciado dos clones nas cargas de álcali ativo foi detectado como interação significativa clone $\mathrm{x}$ álcali ativo na análise de variância geral.

O Teste de Tukey mostrou que a análise de álcali ativo dentro de clone revelou comportamentos diferenciados para os clones. A alvura final da polpa do clone G-31 decresceu com a elevação das cargas de álcali ativo. A alvura da polpa do clone C-41 aumentou com a elevação das cargas de álcali ativo. A análise de variância revelou que o comportamento acima foi mais significativo para o clone C-41 em relação ao clone G-31. Este resultado tem importância pois mostrou que a utilização de cargas mais elevadas de álcali ativo no clone de baixa densidade (G-31) prejudicou significativamente a alvura final da polpa. A provável explicação deste resultado pode ser atribuída a maior degradação dos polissacarídeos na madeira de baixa densidade na polpação e branqueamento (introdução de grupos cromóforos nas cadeias de celulose e hemiceluloses) e perda de alvura nas cargas de álcali ativo mais elevadas. Portanto, a alvura final da polpa branqueada pode aumentar ou diminuir com a elevação da carga alcalina, pois depende das características e propriedades do clone. Conforme relatado na revisão de literatura, Axelsson et al. (s.n.t.) e Pascoal Neto (2003) relatam em seus trabalhos que a branqueabilidade se eleva com o aumento da carga alcalina.

Os fatores mais influentes na alvura após $D_{1}$ foram, em ordem decrescente, interação clone $x$ álcali ativo, clone e álcali ativo.

\subsection{Morfologia das fibras na polpa branqueada em Kajaani FS 200}

A morfologia das fibras nas polpas branqueadas dos dois clones (G-31 e C-41) nos três níveis de álcali ativo (12,5\%, 13,5\% e 14,5\%) foi analisada quanto ao comprimento médio ponderado por comprimento, largura, diâmetro do lume, espessura da parede, índice de enfeltramento, coeficiente de flexibilidade, 
fração parede, índice de Runkel, índice de curvatura da fibra, "coarseness", população fibrosa e teor de finos.

A Figura 26 mostra o comprimento médio ponderado da fibra. A análise de variância geral mostrou efeito significativo, somente, para clone no comprimento médio ponderado da fibra. A análise de variância de álcali ativo dentro de clone não foi significativa para o clone G-31 e clone C-41. A análise de variância de clone dentro de álcali ativo foi significativa, em ordem decrescente para 14,5\%, 12,5\% e 13,5\% de álcali ativo.

Os resultados obtidos através do Teste de Tukey revelaram que a análise de clone dentro de álcali ativo mostrou maior comprimento médio ponderado da fibra para o clone G-31 em todas cargas de álcali ativo. A análise de álcali ativo dentro de clone não mostrou diferenças significativas, indicando que o comprimento da fibra não foi alterado quando se elevou a carga de álcali ativo. O fator mais importante no comprimento médio ponderado da fibra foi clone.

Conforme pode ser observado na Figura 26, o comprimento médio da fibra na polpa em Kajaani FS-200 é menor que o comprimento da fibra usualmente encontrado na madeira. A literatura especializada mostra que as dimensões das fibras se alteram quando determinadas na madeira e nas fibras da polpa utilizando analisador óptico automático (Levlin \& Söderhjem, 1999; Trepanier, 1998 e Braaten \& Molteberg, 2004). As seguintes explicações são apontadas para explicar o menor comprimento da fibra na polpa em analisador óptico automático: a madeira é reduzida a cavacos e esta operação pode cortar as fibras se não for efetuada de forma correta; as fibras na polpa branqueada apresentam curvaturas graduais e continua ("curl") e curvaturas torcidas ("kink") devido a tratamentos mecânicos, significando que o comprimento projetado avaliado no Kajaani é menor que o comprimento real; algumas fibras no fluxo que passam pelo analisador podem estar desorientadas significando que o comprimento projetado é menor que o real e o Kajaani pode medir fibras quebradas como se fosse fibra inteira. Então, o menor comprimento observado no analisador automático óptico é uma somatória dos fatores relatados acima. 
Na madeira, as fibras são retas (Robertson et al., 1999) e a medição só é efetuada nas fibras inteiras.

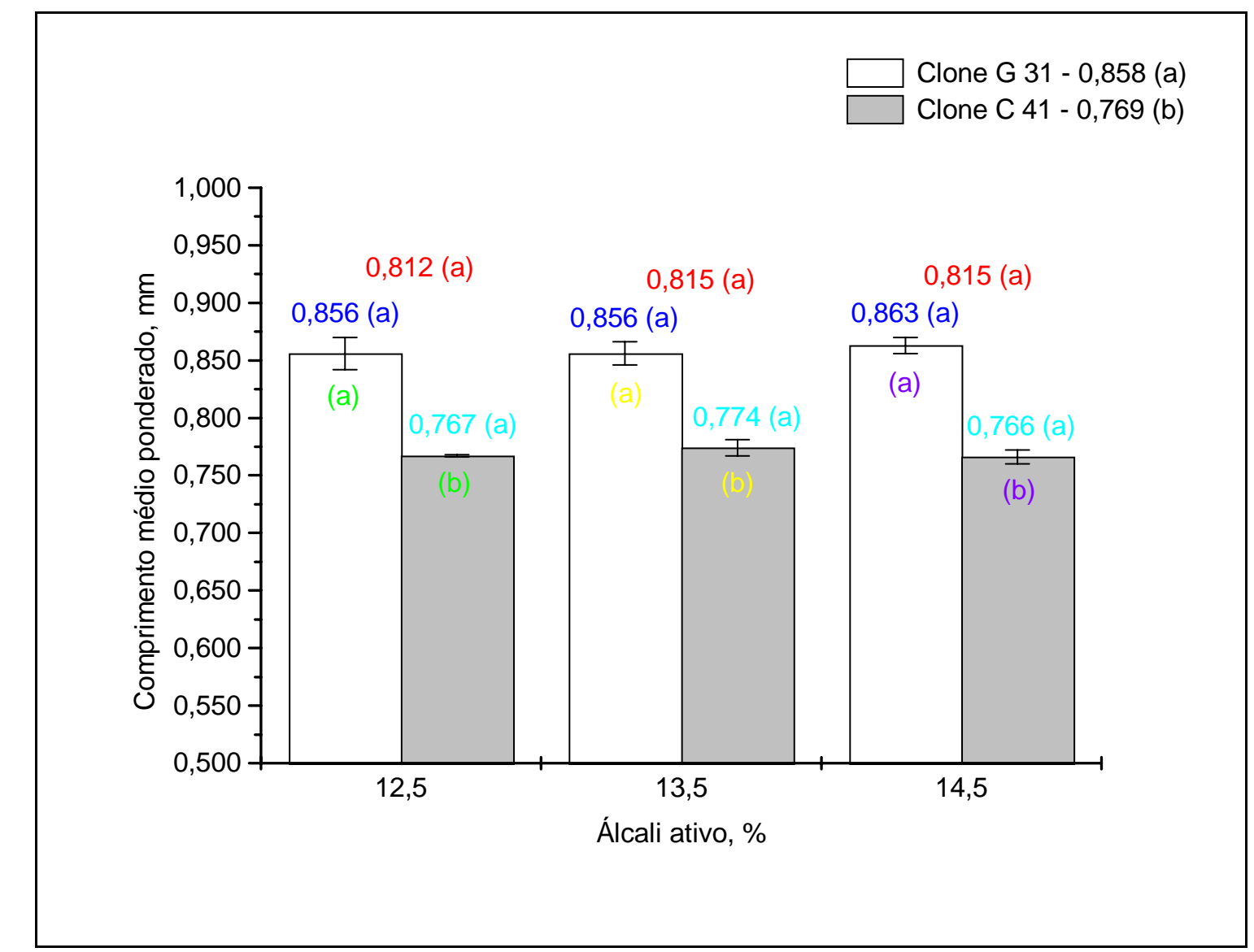

Figura 26 - Comprimento médio ponderado da fibra

A Figura 27 refere-se a largura da fibra. A análise de variância geral mostrou efeito significativo, em ordem decrescente, para clone e álcali ativo na largura da fibra. A análise de variância de álcali ativo dentro de clone foi significativa, somente, para o clone C-41. A análise de variância de clone dentro de álcali ativo foi significativa, em ordem decrescente, para 14,5\%, 13,5\% e $12,5 \%$ de álcali ativo.

O Teste de Tukey revelou que a análise de clone dentro de álcali ativo mostrou maior largura da fibra para o clone G-31 sendo significativo, somente, 
para $14,5 \%$ de álcali ativo. A análise de álcali ativo dentro de clone mostrou tendências de decréscimo da largura da fibra com a elevação da carga de álcali ativo, obtendo diferenças significativas dentro do clone C-41, conforme indicadas na Figura 27. Os fatores que influenciaram na largura da fibra foram clone e álcali ativo.

Levlin \& Söderhjem (1999) relatam que nos processos de polpação e branqueamento, lignina e hemiceluloses são solubilizadas da parede celular e tornam as fibras mais finas e mais flexíveis.

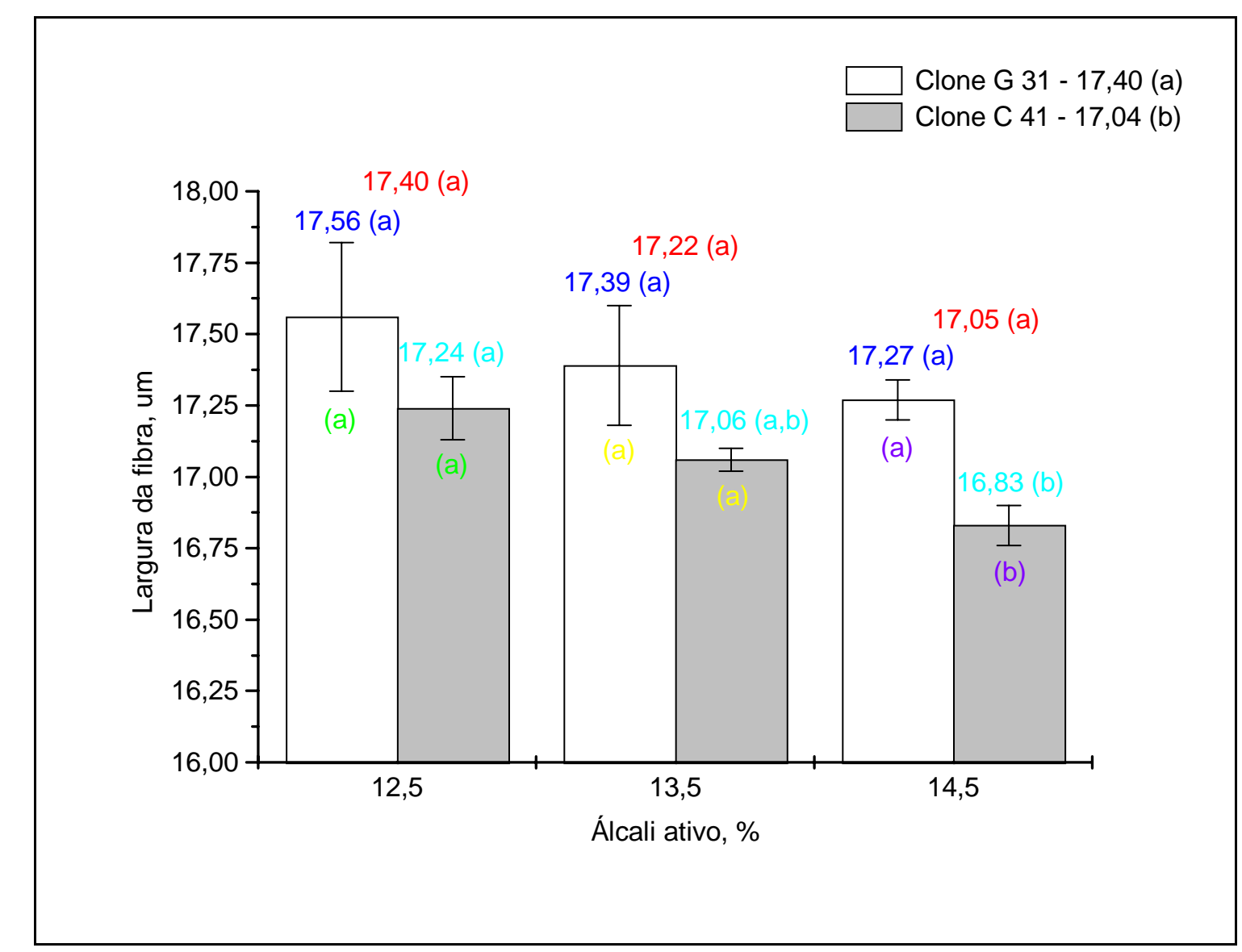

Figura 27 - Largura da fibra

A Figura 28 mostra o diâmetro do lume da fibra. A análise de variância geral mostrou efeito significativo, em ordem decrescente, para clone e álcali 
ativo no diâmetro do lume da fibra. A análise de variância de álcali ativo dentro de clone foi significativa, em ordem decrescente, para o clone C-41 e clone G31. A análise de variância de clone dentro de álcali ativo foi significativa, em ordem decrescente para 12,5\%, 13,5\% e 14,5\% de álcali ativo.

Os resultados do Teste de Tukey mostraram que a análise de clone dentro de álcali ativo mostrou maior diâmetro do lume da fibra para o clone C-41 em todas cargas de álcali ativo. A análise de álcali ativo dentro de clone mostrou decréscimo no diâmetro do lume da fibra com a elevação da carga de álcali ativo, obtendo diferenças significativas dentro do clone G-31 e C-41, conforme indicadas na Figura 28. A análise de álcali ativo dentro de clone mostra comportamentos distintos para os clones. A análise de variância revelou uma influência mais significativa para o clone C-41 em comparação com o clone G31, ou seja, maior decréscimo do diâmetro do lume da fibra no clone C-41.

Os fatores mais influentes no diâmetro do lume da fibra foram clone e álcali ativo. 


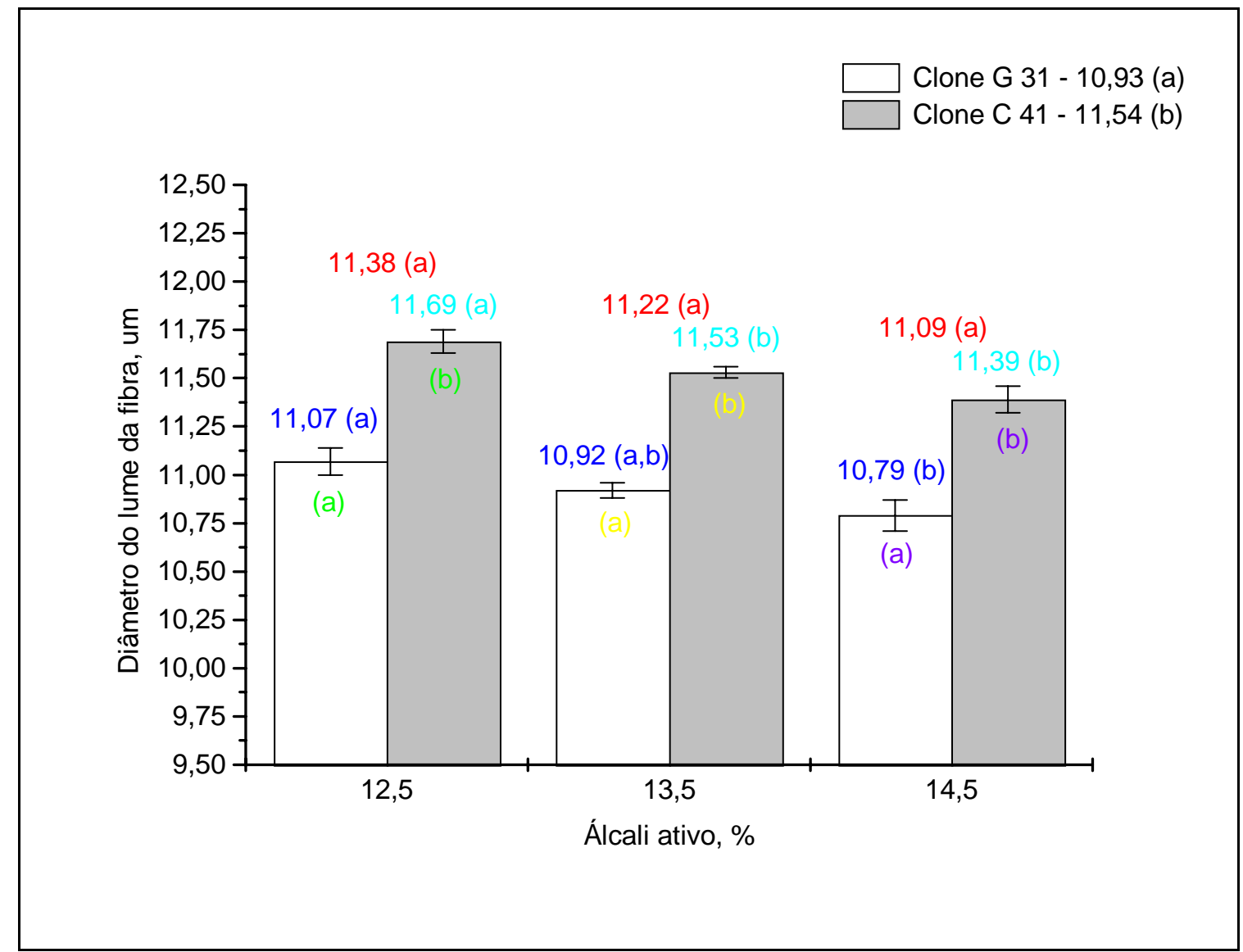

Figura 28 - Diâmetro do lume da fibra

A Figura 29 mostra a espessura da parede da fibra. A análise de variância geral mostrou efeito significativo, somente, para clone na espessura da parede da fibra. A análise de variância de álcali ativo dentro de clone não foi significativa para o clone C-41 e clone G-31. A análise de variância de clone dentro de álcali ativo foi significativa, em ordem decrescente para 14,5\%, 13,5\% e $12,5 \%$ de álcali ativo.

O Teste de Tukey revelou que a análise de clone dentro de álcali ativo mostrou maior espessura da parede da fibra para o clone G-31 (menor densidade básica) em todas cargas de álcali ativo. A análise de álcali ativo dentro de clone não mostrou diferenças significativas, indicando que a 
espessura da parede da fibra não foi alterada quando se elevou a carga de álcali ativo. O fator mais importante na espessura da parede da fibra foi o clone.

Dinus \& Welt (1997) relatam que a alta densidade básica em híbridos de Eucalyptus pode ser devido a um elevado número de fibras com lume estreito e paredes celulares relativamente finas e flexíveis.

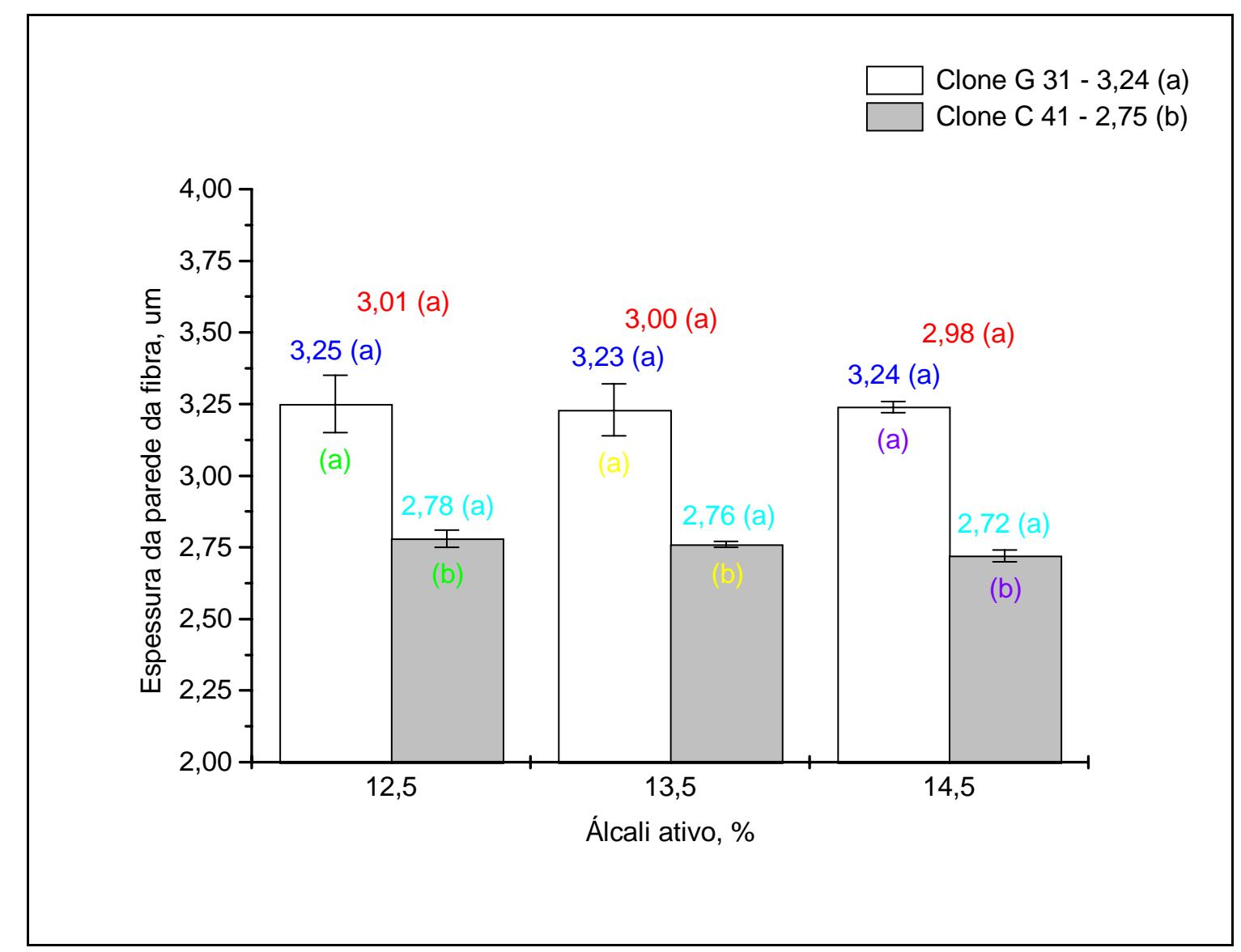

Figura 29 - Espessura da parede da fibra

A Figura 30 mostra o índice de enfeltramento da fibra. A análise de variância geral mostrou efeito significativo, em ordem decrescente, para clone e álcali ativo no índice de enfeltramento da fibra. A análise de variância de álcali ativo dentro de clone foi significativa, em ordem decrescente, para o clone C-41 
e clone G-31. A análise de variância de clone dentro de álcali ativo foi significativa, em ordem decrescente para 14,5\%, 12,5\% e 13,5\% de álcali ativo.

Os resultados do Teste de Tukey mostraram que a análise de clone dentro de álcali ativo mostrou maior índice de enfeltramento da fibra para o clone G-31 em todas cargas de álcali ativo. Este resultado pode ser atribuído ao maior comprimento da fibra do clone G-31. A análise de álcali ativo dentro de clone mostrou acréscimo no índice de enfeltramento da fibra com a elevação da carga de álcali ativo, obtendo diferenças significativas dentro do clone G-31 e C41, conforme indicadas na Figura 30. A análise de álcali ativo dentro de clone mostra comportamentos distintos para os clones. A análise de variância revelou uma influência mais significativa para o clone C-41 em comparação com o clone G-31, ou seja, maior acréscimo no índice de enfeltramento da fibra no clone C41. Os fatores que mais influenciaram no índice de enfeltramento da fibra foram clone e álcali ativo. 


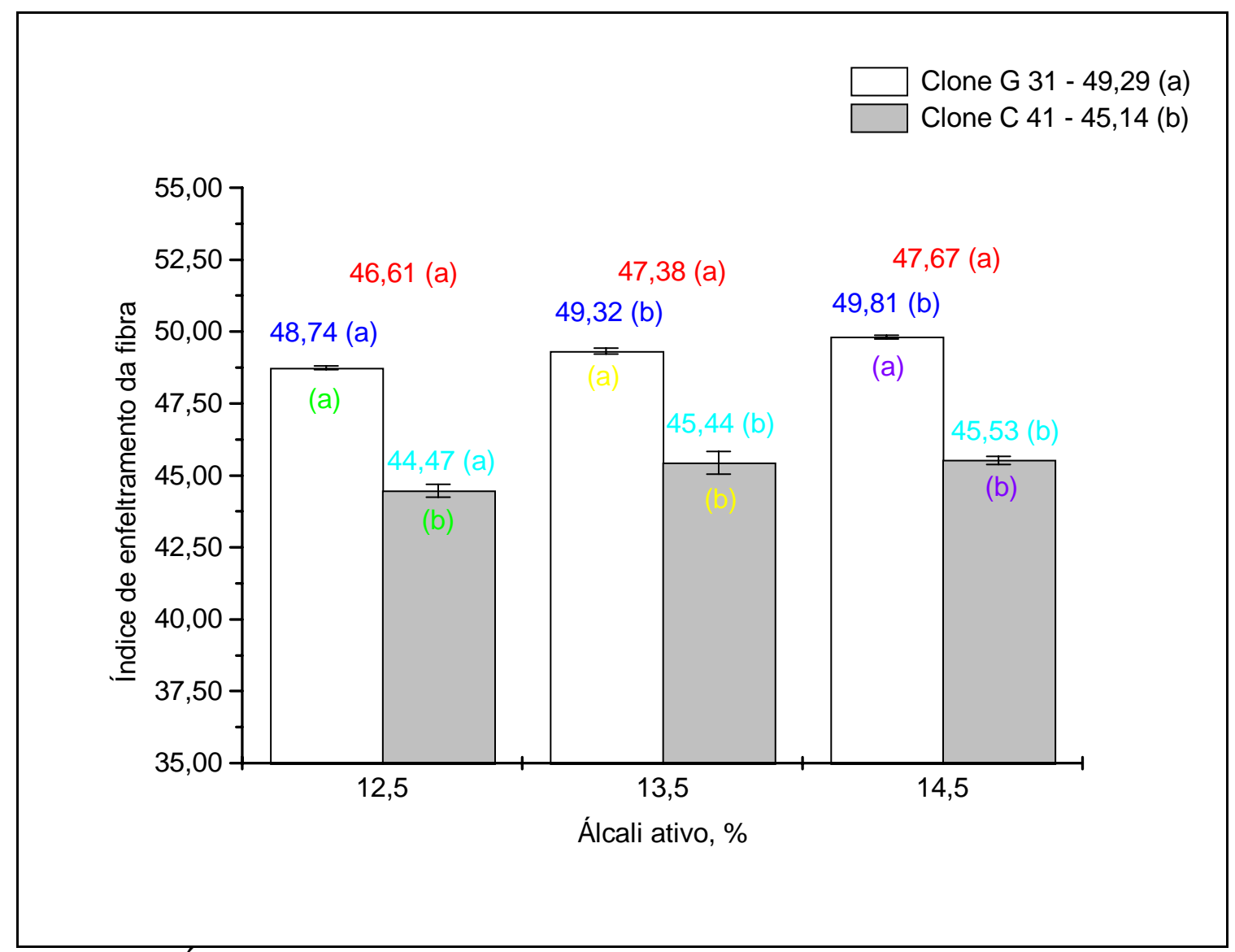

Figura 30 - Índice de enfeltramento da fibra

A Figura 31 mostra o coeficiente de flexibilidade da fibra. A análise de variância geral mostrou efeito significativo, somente, para clone no coeficiente de flexibilidade da fibra. A análise de variância de álcali ativo dentro de clone não foi significativa para o clone G-31 e clone C-41. A análise de variância de clone dentro de álcali ativo foi significativa, em ordem decrescente para $14,5 \%$, $13,5 \%$ e $12,5 \%$ de álcali ativo.

O Teste de Tukey revelou que a análise de clone dentro de álcali ativo mostrou maior coeficiente de flexibilidade da fibra para o clone C-41 em todas cargas de álcali ativo. O coeficiente de flexibilidade é a relação entre o diâmetro do lume e a largura da fibra. Como visto nas Figuras 27 e 28, o clone C-41 
apresentou fibras com menor largura e maior diâmetro do lume, respectivamente, portanto o coeficiente de flexibilidade da fibra nas polpas produzidas a partir do clone C-41 foi maior em relação ao clone G-31. A análise de álcali ativo dentro de clone não mostrou diferenças significativas, indicando que o coeficiente de flexibilidade da fibra não foi alterado quando se elevou a carga de álcali ativo. Tais resultados são justificáveis porque tanto o diâmetro do lume quanto a largura da fibra diminuíram com a elevação das dosagens de álcali ativo. O fator mais importante no coeficiente de flexibilidade da fibra foi o clone.

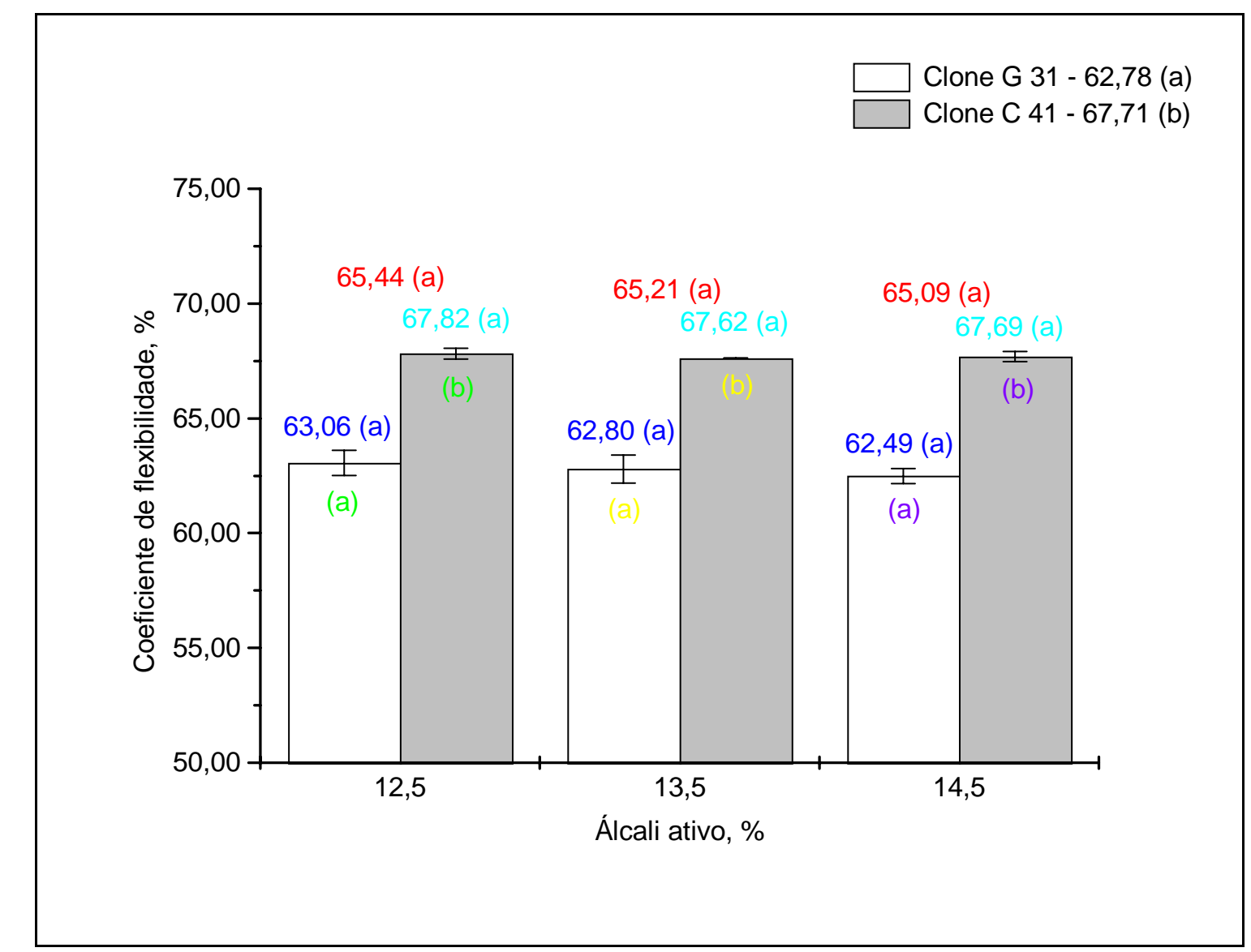

Figura 31 - Coeficiente de flexibilidade da fibra

A Figura 32 mostra a fração parede da fibra. A análise de variância geral mostrou efeito significativo, somente, para clone na fração parede da fibra. A 
análise de variância de álcali ativo dentro de clone não foi significativa para o clone G-31 e clone C-41. A análise de variância de clone dentro de álcali ativo foi significativa, em ordem decrescente para 14,5\%, 12,5\% e 13,5\% de álcali ativo.

Pelo Teste de Tukey a análise de clone dentro de álcali ativo mostrou maior fração parede da fibra para o clone G-31 em todas cargas de álcali ativo. A análise de álcali ativo dentro de clone não mostrou diferenças significativas, indicando que a fração parede da fibra não foi alterada quando se elevou a carga de álcali ativo. O fator mais importante na fração parede da fibra foi clone.

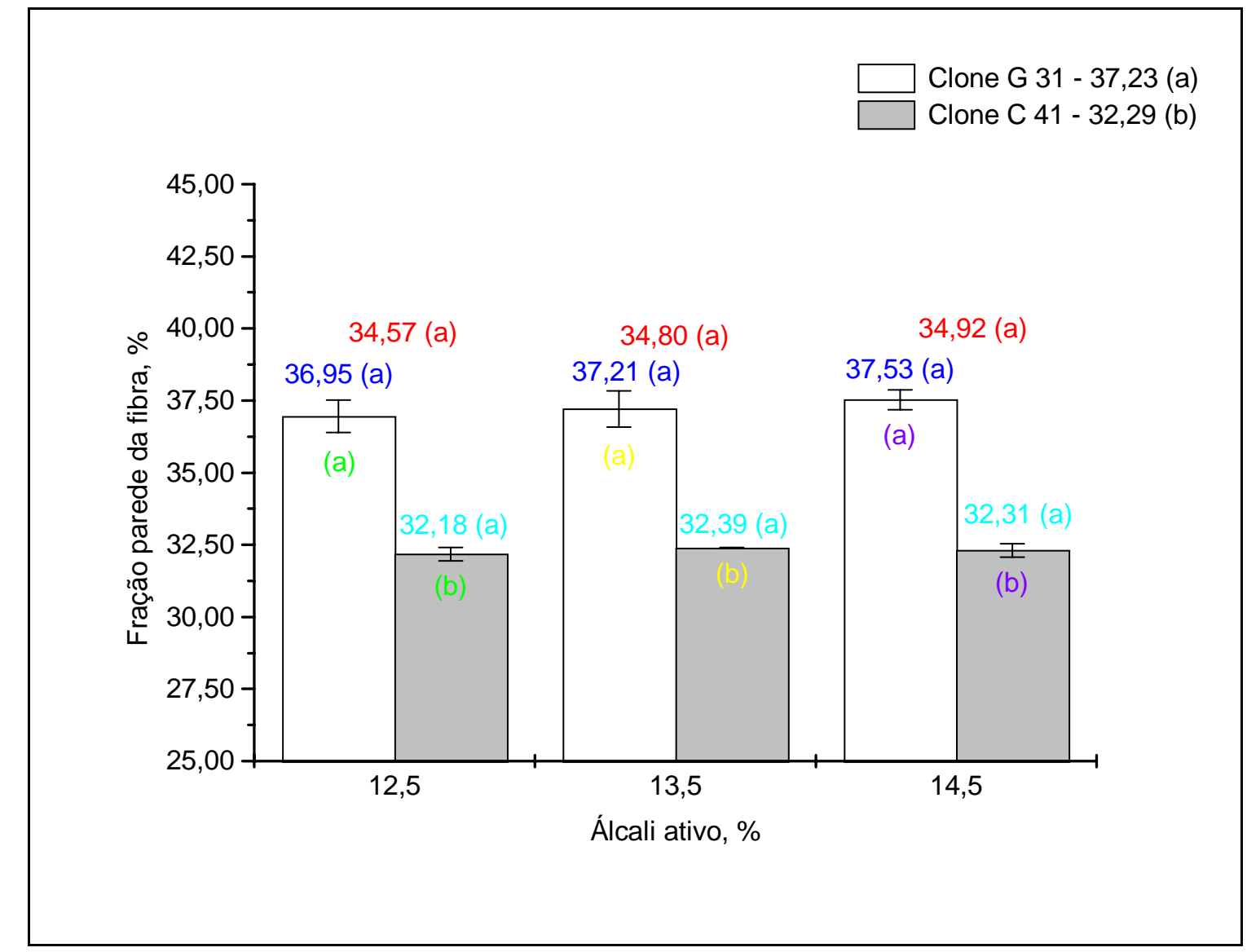

Figura 32 - Fração parede da fibra 
A Figura 33 mostra o índice de Runkel da fibra. A análise de variância geral mostrou efeito significativo, somente, para clone no índice de Runkel da fibra. A análise de variância de álcali ativo dentro de clone não foi significativa para o clone G-31 e clone C-41. A análise de variância de clone dentro de álcali ativo foi significativa, em ordem decrescente para 14,5\%, 12,5\% e 13,5\% de álcali ativo.

Os resultados do Teste de Tukey revelaram que a análise de clone dentro de álcali ativo mostrou maior índice de Runkel da fibra para o clone G-31 em todas cargas de álcali ativo. O índice de Runkel é a razão entre duas vezes a espessura da parede celular e o diâmetro do lume. O maior índice de Runkel da fibra do clone G-31 pode ser explicado pelo menor diâmetro do lume e maior espessura de parede apresentado neste clone, conforme mostram as figuras 28 e 29, respectivamente. A análise de álcali ativo dentro de clone não mostrou diferenças significativas, indicando que o índice de Runkel da fibra não foi alterado quando se elevou a carga de álcali ativo. O fator que mais influenciou no índice de Runkel da fibra foi clone. 


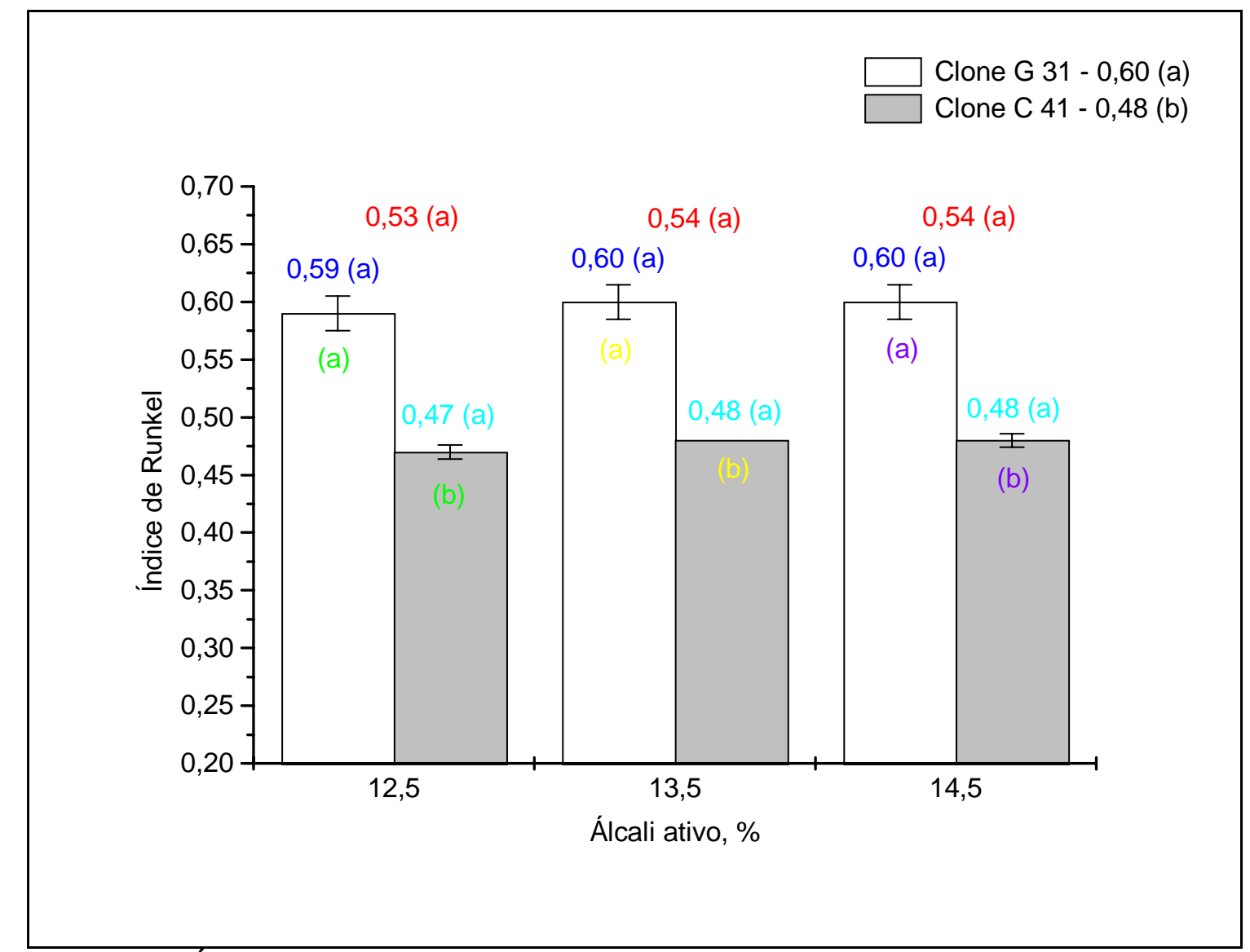

Figura 33 - Índice de Runkel da fibra

A Figura 34 mostra o índice de curvatura da fibra. A análise de variância geral mostrou efeito significativo, em ordem decrescente, para clone, interação clone $x$ álcali ativo e álcali ativo no índice de curvatura da fibra. A interação significativa indica que o comportamento dos clones depende das cargas de álcali ativo. Neste caso, as médias gerais não podem ser comparadas. A análise de variância de álcali ativo dentro de clone foi significativa, somente, para o clone C-41. A análise de variância de clone dentro de álcali ativo foi significativa, somente, para $12,5 \%$ de álcali ativo.

Conforme poder ser observado na Figura 34, o Teste de Tukey mostrou que a análise de clone dentro de álcali ativo revelou comportamento 
diferenciado. Os clones G-31 e C-41 apresentaram médias iguais, estatisticamente, nas cargas de 13,5\% e 14,5\% de álcali ativo. Porém, na carga de $12,5 \%$ de álcali ativo, a curvatura da fibra do clone G-31 foi significativamente superior quando comparada com o clone C-41. Este comportamento diferenciado dos clones nas cargas de álcali ativo foi detectado como interação significativa clone $x$ álcali ativo na análise de variância geral. A maior curvatura das fibras do clone G-31 em 12,5\% de álcali ativo significa maiores desvios em relação ao eixo da célula. O índice de curvatura da fibra tem influência no comprimento da fibra (Levlin \& Söderhjelm, 1999) e na qualidade e desempenho do produto final (Trepanier, 1988). A análise de álcali ativo dentro de clone não mostrou um comportamento definido. Paavilainen (1989) verificou que com o aumento da carga de álcali ativo fica evidente o maior enrijecimento das fibras.

Os fatores mais influentes na curvatura da fibra foram, em ordem decrescente, clone, interação clone x álcali ativo e álcali ativo. 


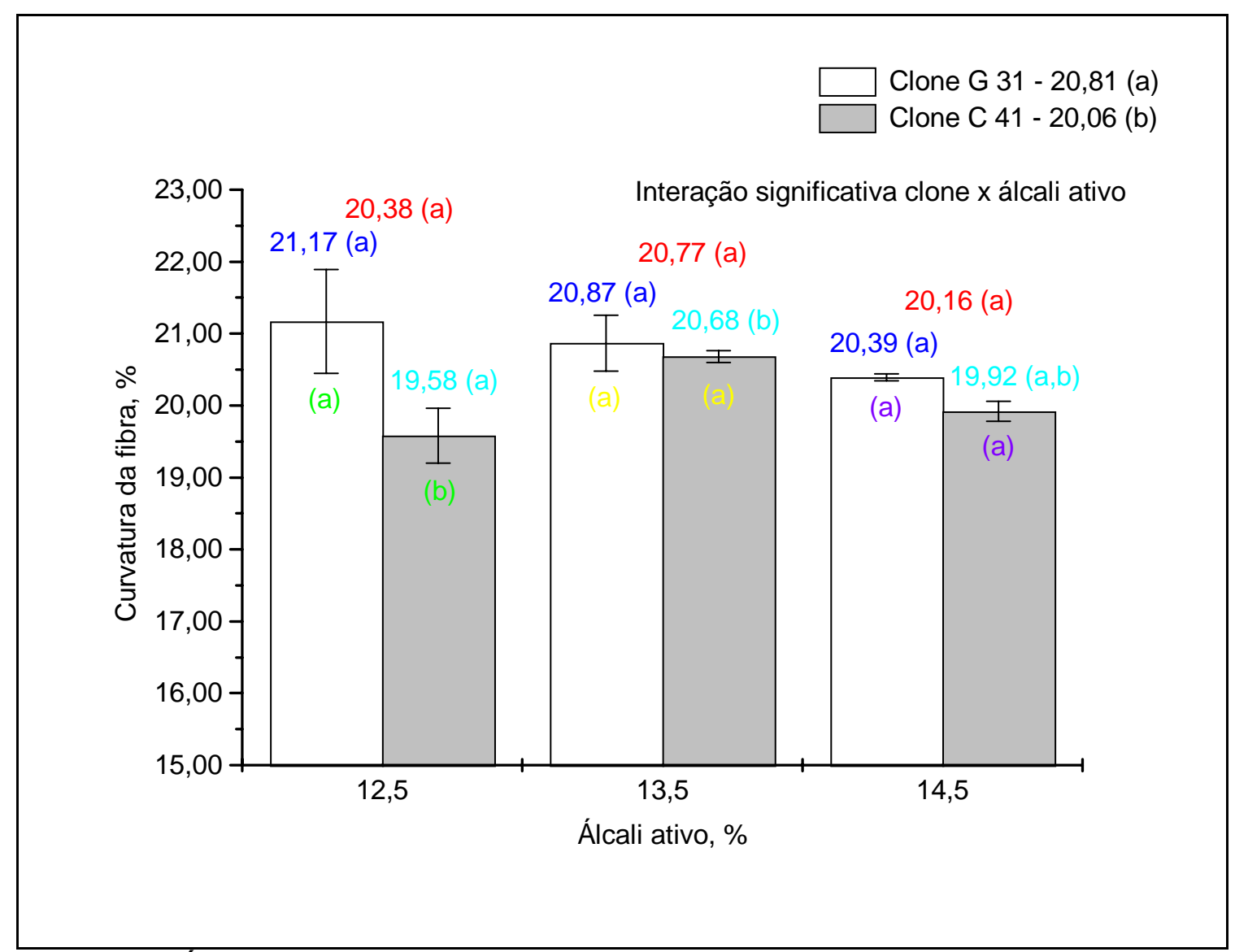

Figura 34 - Índice de curvatura da fibra

A Figura 35 mostra a "coarseness" da fibra. A análise de variância geral mostrou efeito significativo, somente, para clone na "coarseness" da fibra. A análise de variância de álcali ativo dentro de clone não foi significativa para o clone C-41 e clone G-31. A análise de variância de clone dentro de álcali ativo foi significativa, em ordem decrescente para 14,5\%, 12,5\% e 13,5\% de álcali ativo.

O Teste de Tukey revelou que a análise de clone dentro de álcali ativo mostrou maior "coarseness" da fibra para o clone C-41 em todas cargas de álcali ativo. A análise de álcali ativo dentro de clone não mostrou diferenças significativas, indicando que a "coarseness" da fibra não foi alterada quando se 
elevou a carga de álcali ativo. O fator mais importante na "coarseness" da fibra foi o clone.

É importante ressaltar que as fibras do clone C-41 (menor fração parede) apresentou maior "coarseness" que as fibras do clone G-31 (maior fração parede) mostrando fibras mais pesadas. A "coarseness" das fibras depende da seção transversal e comprimento da fibra e a fração parede, somente, da seção transversal da fibra.

Segundo Seth \& Chan (1997), a "coarseness" afeta as respostas das fibras na fabricação do papel e altera várias propriedades da estrutura, resistência e óptica do produto.

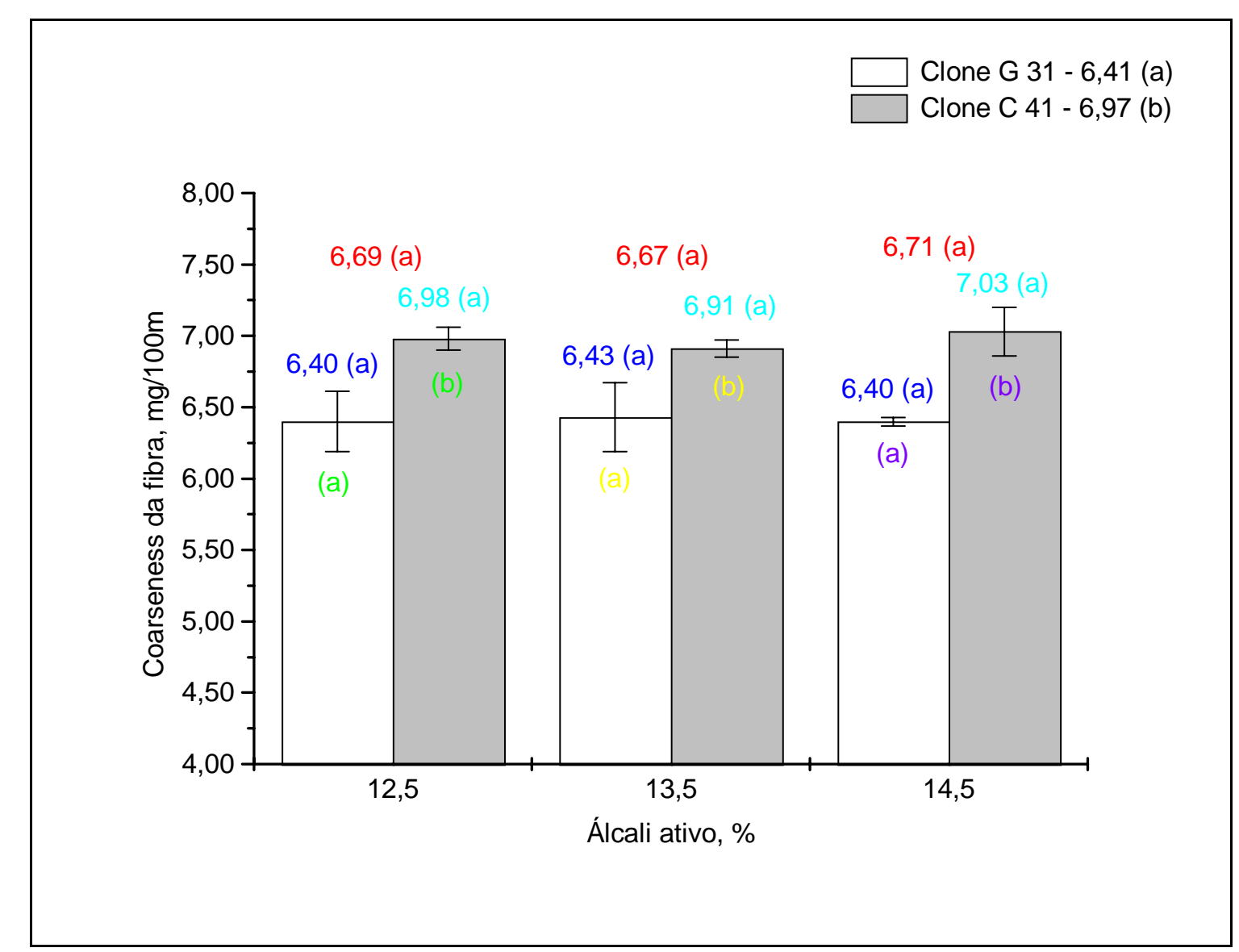

Figura 35 - "Coarseness" da fibra 
A Figura 36 mostra a população fibrosa. A análise de variância geral mostrou efeito significativo, somente, para clone na população fibrosa. A análise de variância de álcali ativo dentro de clone não foi significativa para o clone C-41 e clone G-31. A análise de variância de clone dentro de álcali ativo não foi significativa para $12,5 \%, 13,5 \%$ e $14,5 \%$ de álcali ativo.

A análise de clone dentro de álcali ativo mostrou maior população fibrosa para o clone C-41, entretanto, os contrastes entre médias do Teste de Tukey nas cargas de álcali ativo não foram significativos. As médias gerais mostraram diferenças significativas, ou seja, o clone C-41 apresentou maior população fibrosa que o clone G-31. Este resultado era esperado, pois as fibras do clone C-41 são menores (menor comprimento e menor largura da fibra) em relação ao clone G-31 e, então, maior população fibrosa. A análise de álcali ativo dentro de clone não mostrou diferenças significativas, indicando que a população fibrosa não foi alterada quando se elevou a carga de álcali ativo. O fator mais importante na população fibrosa foi o clone. 


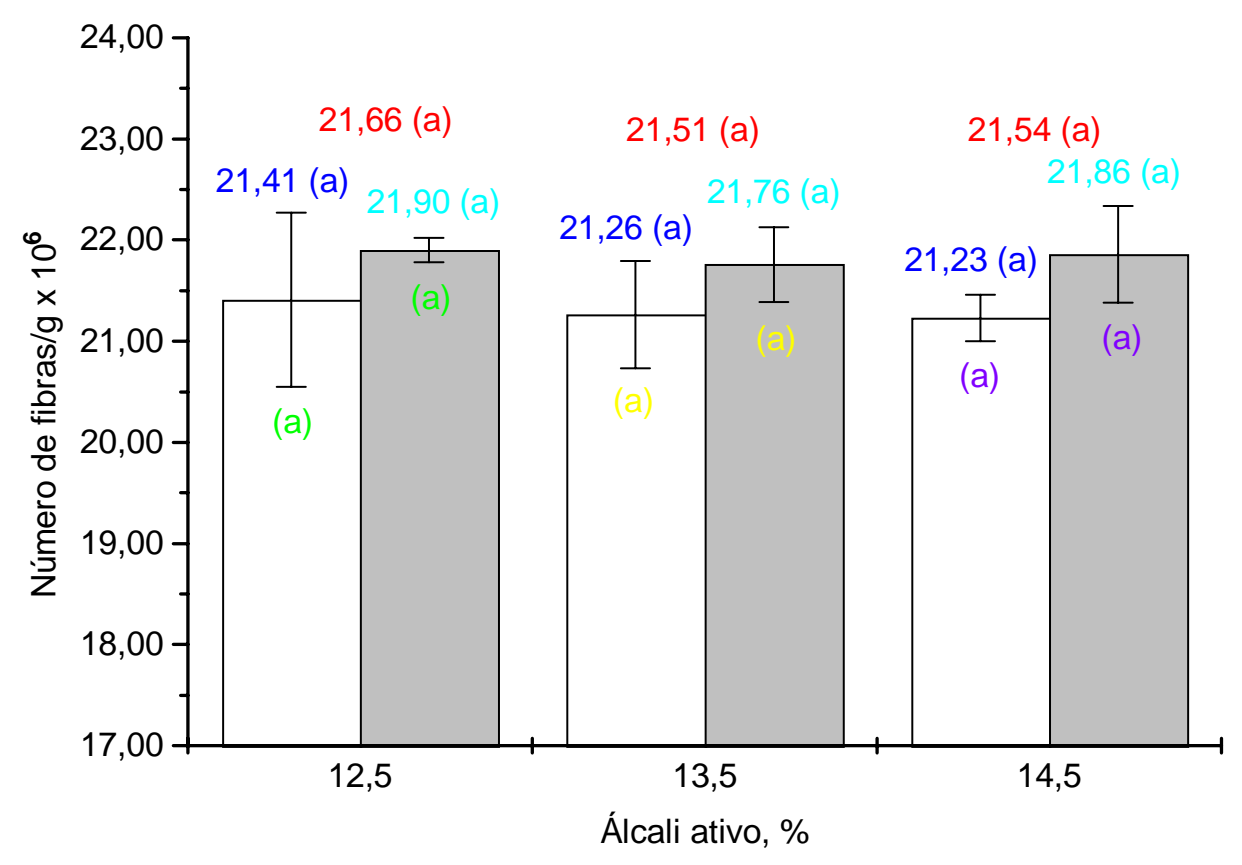

Figura 36 - População fibrosa

A Figura 37 mostra o teor de finos menor que 0,1 mm (média aritmética). A análise de variância geral não mostrou efeito significativo no teor de finos menor que $0,1 \mathrm{~mm}$. A análise de variância de álcali ativo dentro de clone foi significativa, somente, para o clone C-41. A análise de variância de clone dentro de álcali ativo não foi significativa para 12,5\%, 13,5\% e 14,5\% de álcali ativo.

Conforme pode ser observado na Figura 37, os resultados não mostraram nenhuma influência dos fatores clone e álcali ativo no teor de finos menor que $0,1 \mathrm{~mm}$. 


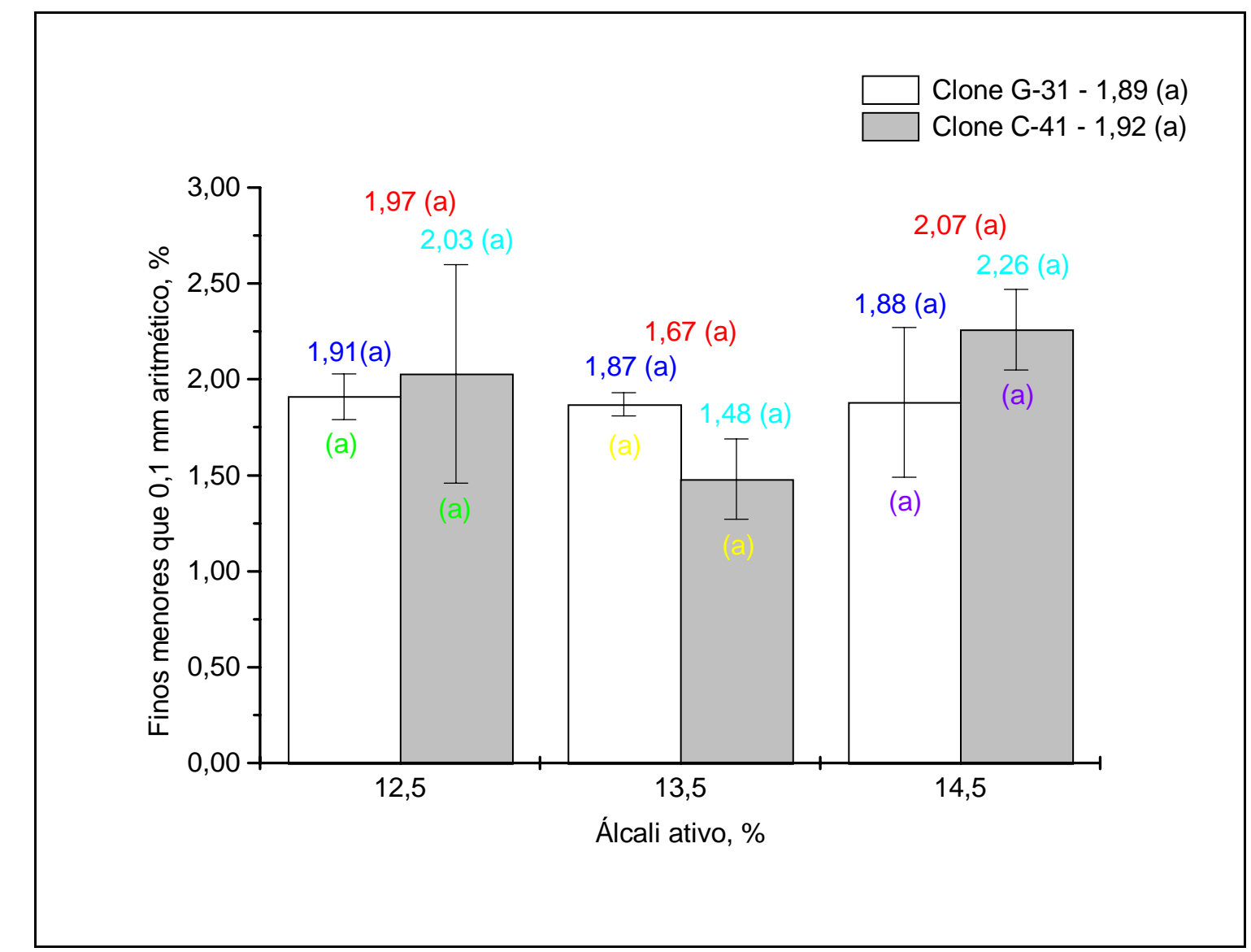

Figura 37 - Teor de finos menor que 0,1 mm (média aritmética)

A Figura 38 mostra o teor de finos menor que 0,2 mm (média aritmética). A análise de variância geral mostrou efeito significativo, em ordem decrescente, para álcali ativo e interação clone $x$ álcali ativo no teor de finos menor que 0,2 $\mathrm{mm}$. A interação significativa indica que o comportamento dos clones depende das cargas de álcali ativo. Neste caso, as médias gerais não podem ser comparadas. A análise de variância de álcali ativo dentro de clone foi significativa, somente, para o clone C-41. A análise de variância de clone dentro de álcali ativo foi significativa, somente, para 14,5\% de álcali ativo.

Conforme pode ser observado na Figura 38, o Teste de Tukey mostrou que a análise de clone dentro de álcali ativo revelou comportamento 
diferenciado. Os clones G-31 e C-41 apresentaram médias iguais em todas cargas de álcali ativos. Porém, o comportamento dos clones nas cargas de álcali ativo foi detectado como interação significativa clone $x$ álcali ativo na análise de variância geral. A análise de álcali ativo dentro de clone mostra, somente, uma elevação do teor de finos menor que $0,2 \mathrm{~mm}$ para o clone C-41 quando da elevação de $13,5 \%$ para $14,5 \%$ de álcali ativo.

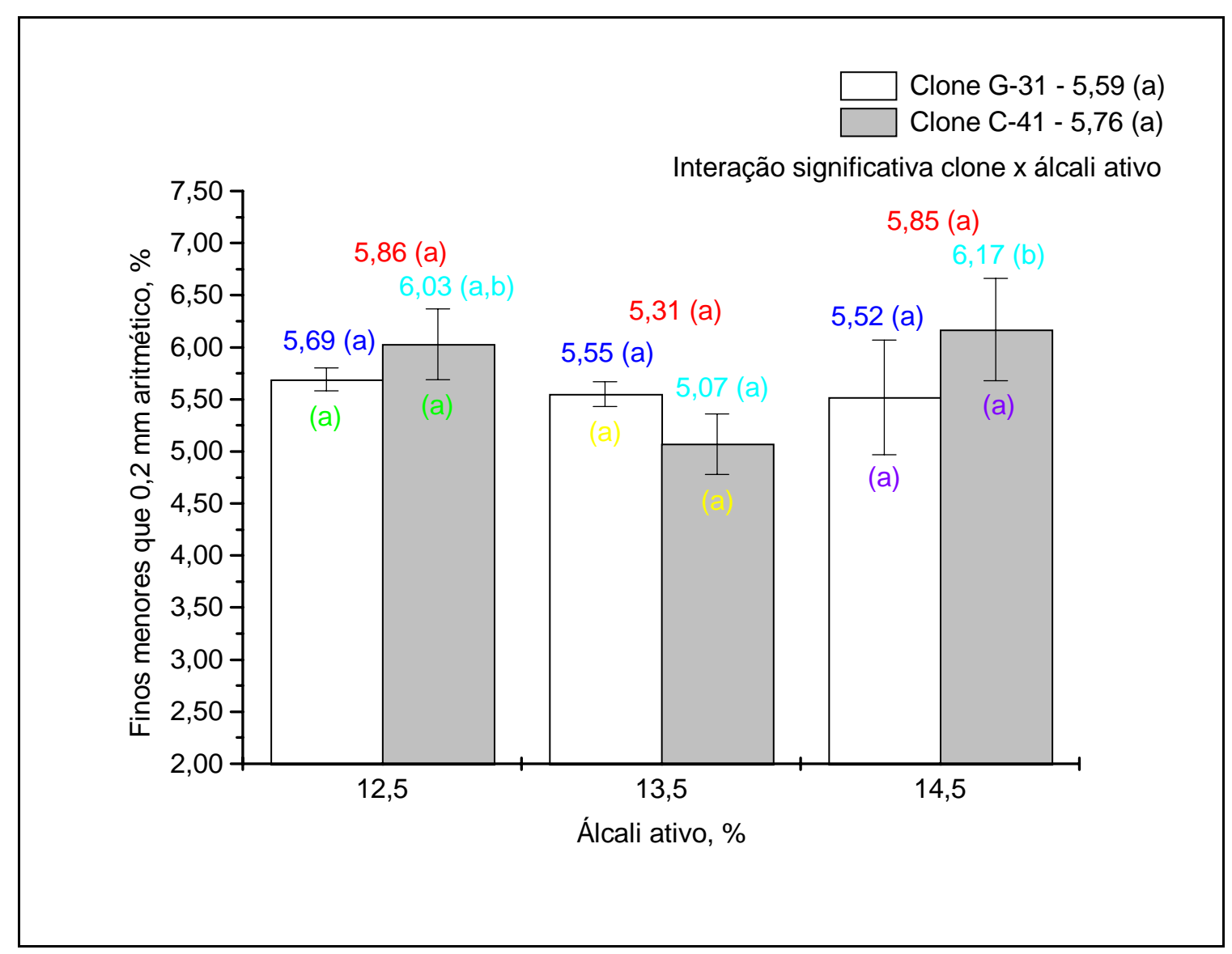

Figura 38 - Teor de finos menor que 0,2 mm (média aritmética) 


\subsection{Propriedades físico-mecânicas da polpa branqueada em índice de tração constante e igual a $70 \mathrm{~N} . \mathrm{m} / \mathrm{g}$}

As propriedades físico-mecânicas das polpas branqueadas, em índice de tração constante e igual a $70 \mathrm{~N} . \mathrm{m} / \mathrm{g}$, dos dois clones (G-31 e C-41) nos três níveis de álcali ativo $(12,5 \%, 13,5 \%$ e 14,5\%) foram analisadas quanto ao número de revoluções no moinho PFI, grau Schopper Riegler, volume específico aparente, peso específico aparente, alongamento, índice de energia absorvida na tração, índice de rigidez na tração, índice de arrebentamento, índice de rasgo, resistência ao ar, índice de retenção de água, ascensão capilar Klemm e opacidade.

A Figura 39 mostra o número de revoluções no PFI para índice de tração de 70 N.m/g. A análise de variância geral mostrou efeito significativo, em ordem decrescente, para clone, álcali ativo e interação clone $\mathrm{x}$ álcali ativo no número de revoluções no $\mathrm{PFI}$. A interação significativa indica que o comportamento dos clones depende das cargas de álcali ativo. Neste caso, as médias gerais não podem ser comparadas. A análise de variância de álcali ativo dentro de clone foi significativa, em ordem decrescente, para o clone C-41 e clone G-31. A análise de variância de clone dentro de álcali ativo foi significativa, em ordem decrescente, para 14,5\%, 13,5\% e 12,5\% de álcali ativo.

Conforme pode ser observado na Figura 39, o Teste de Tukey mostrou que a análise de clone dentro de álcali ativo revelou comportamento diferenciado. A polpa do clone C-41 necessitou maior número de revoluções que a polpa do clone G-31 (+949 revoluções) em 12,5\% de álcali ativo. Nas cargas mais elevadas de álcali ativo, a polpa do clone C-41 necessitou muito mais número de revoluções que a polpa do clone G-31 (+1331 revoluções em álcali ativo $13,5 \%$ e +1154 revoluções em álcali ativo 14,5\%). Este comportamento diferenciado dos clones nas cargas de álcali ativo foi detectado como interação significativa clone $x$ álcali ativo na análise de variância geral. 
A análise de álcali ativo dentro de clone revela comportamento diferente para os clones. O número de revoluções em função do álcali ativo aumentou pouco para a polpa do clone G-31 (não significativo) quando comparado com o aumento para a polpa do clone C-41. Isto significa que a polpa do clone G-31 foi menos sensível a variação de álcali ativo que a polpa do clone C-41 em relação ao número de revoluções. A elevação do número de revoluções com o aumento do álcali ativo pode ser atribuída a perda da viscosidade de celulose e degradação de hemiceluloses. Os fatores que influenciaram no número de revoluções, em ordem de importância, foram clone, álcali ativo e interação clone $x$ álcali ativo.

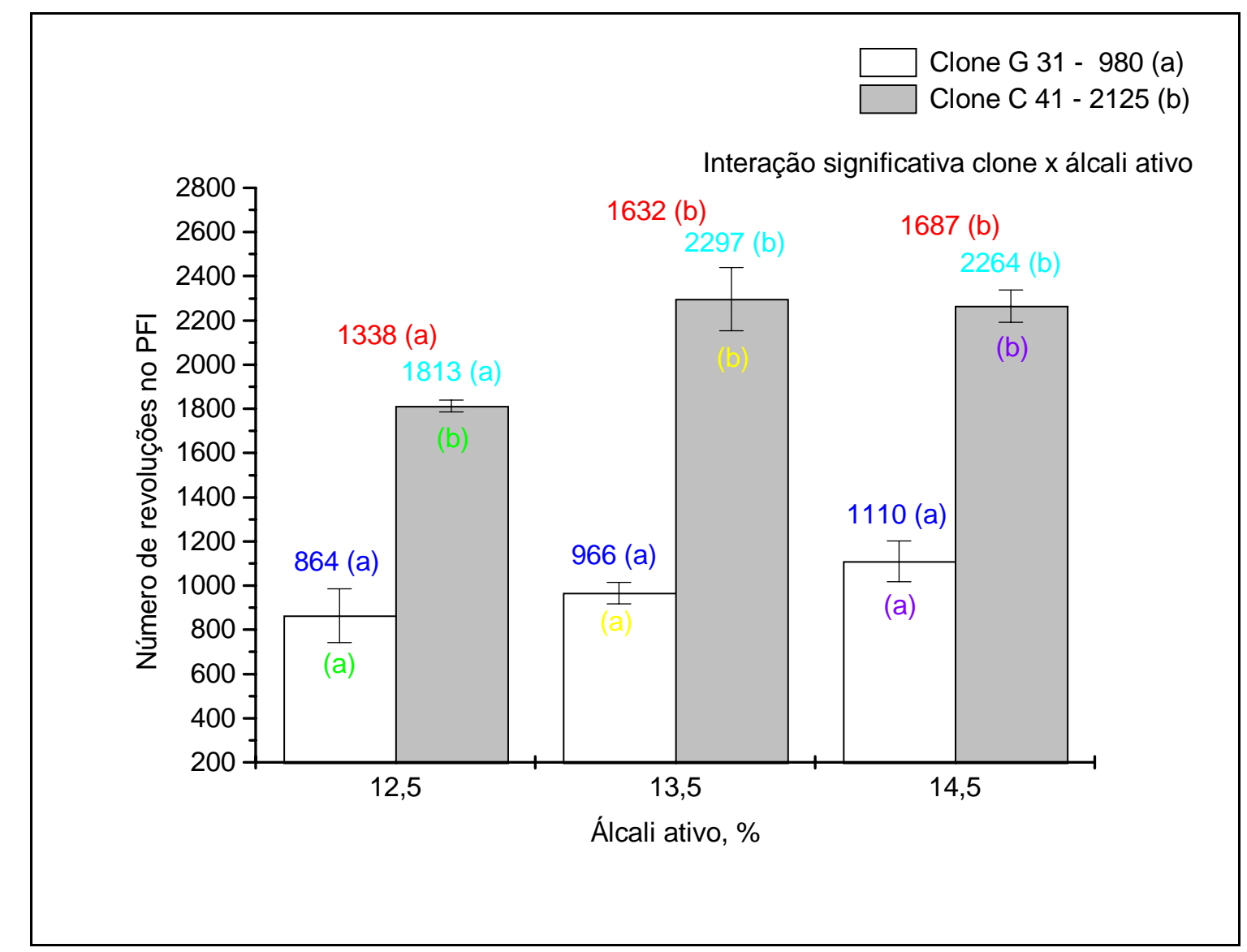

Figura 39 - Número de revoluções no PFI para índice de tração de 70 N.m/g 
O número de revoluções no moinho $\mathrm{PFI}$ é uma determinação fundamental para avaliar o consumo de energia de refino da polpa dos clones. A energia necessária para o refino é um dos maiores custos na fabricação do papel (Cotterill \& Macrae, 1997). Então, o baixo requerimento de refino da polpa do clone G-31 (baixa densidade básica) para atingir o índice de tração de 70 N.m/g é um atrativo para muitos fabricantes de papéis.

A Figura 40 refere-se ao grau Schopper Riegler para índice de tração de 70 N.m/g. A análise de variância geral mostrou efeito significativo, somente, para clone no grau Schopper Riegler. A análise de variância de álcali ativo dentro de clone não foi significativa para o clone G-31 e clone C-41. A análise de variância de clone dentro de álcali ativo foi significativa, em ordem decrescente, para $14,5 \%, 12,5 \%$ e $13,5 \%$ de álcali ativo. 


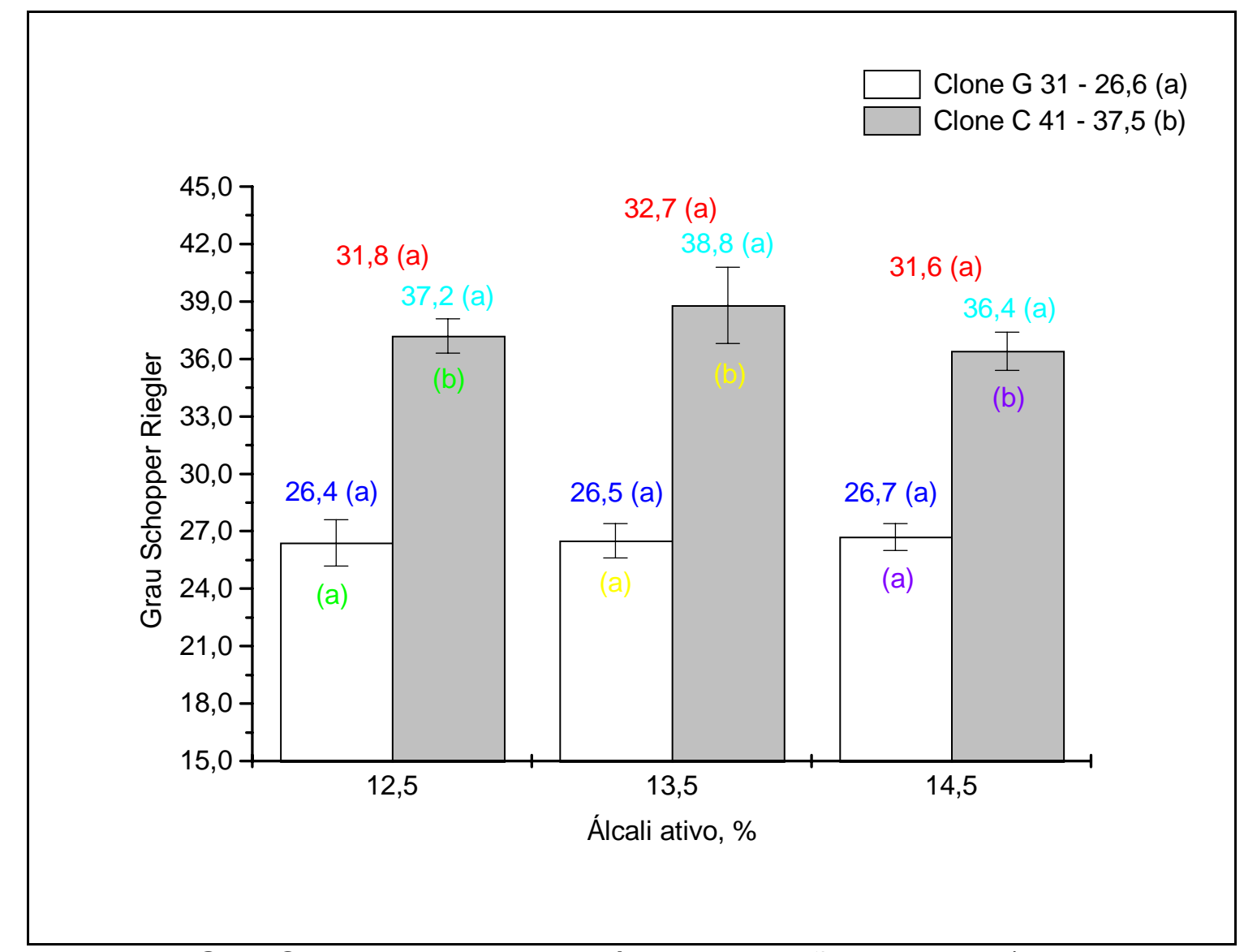

Figura 40 - Grau Schopper Riegler para índice de tração de 70 N.m/g

O grau Shopper Riegler é o parâmetro mais usual para controlar o nível de refino. Conforme pode ser notado na Figura 40, o Teste de Tukey mostrou que a polpa do clone C-41 necessitou de um grau Schopper Riegler muito maior que a polpa do clone G-31 para alcançar o índice de tração de $70 \mathrm{~N} . \mathrm{m} / \mathrm{g}$. A análise de álcali ativo dentro de clone não mostrou diferenças significativas para os clones. O clone foi o fator mais importante que influenciou no grau Schopper Riegler.

A Figura 41 mostra o volume específico aparente para índice de tração de $70 \mathrm{~N} . \mathrm{m} / \mathrm{g}$. A análise de variância geral mostrou efeito significativo, em ordem decrescente, para clone e interação clone $x$ álcali ativo no volume específico 
aparente. A análise de variância de álcali ativo dentro de clone foi significativa, somente, para o clone G-31. A análise de variância de clone dentro de álcali ativo foi significativa, em ordem decrescente, para 12,5\%, 13,5\% e 14,5\% de álcali ativo.

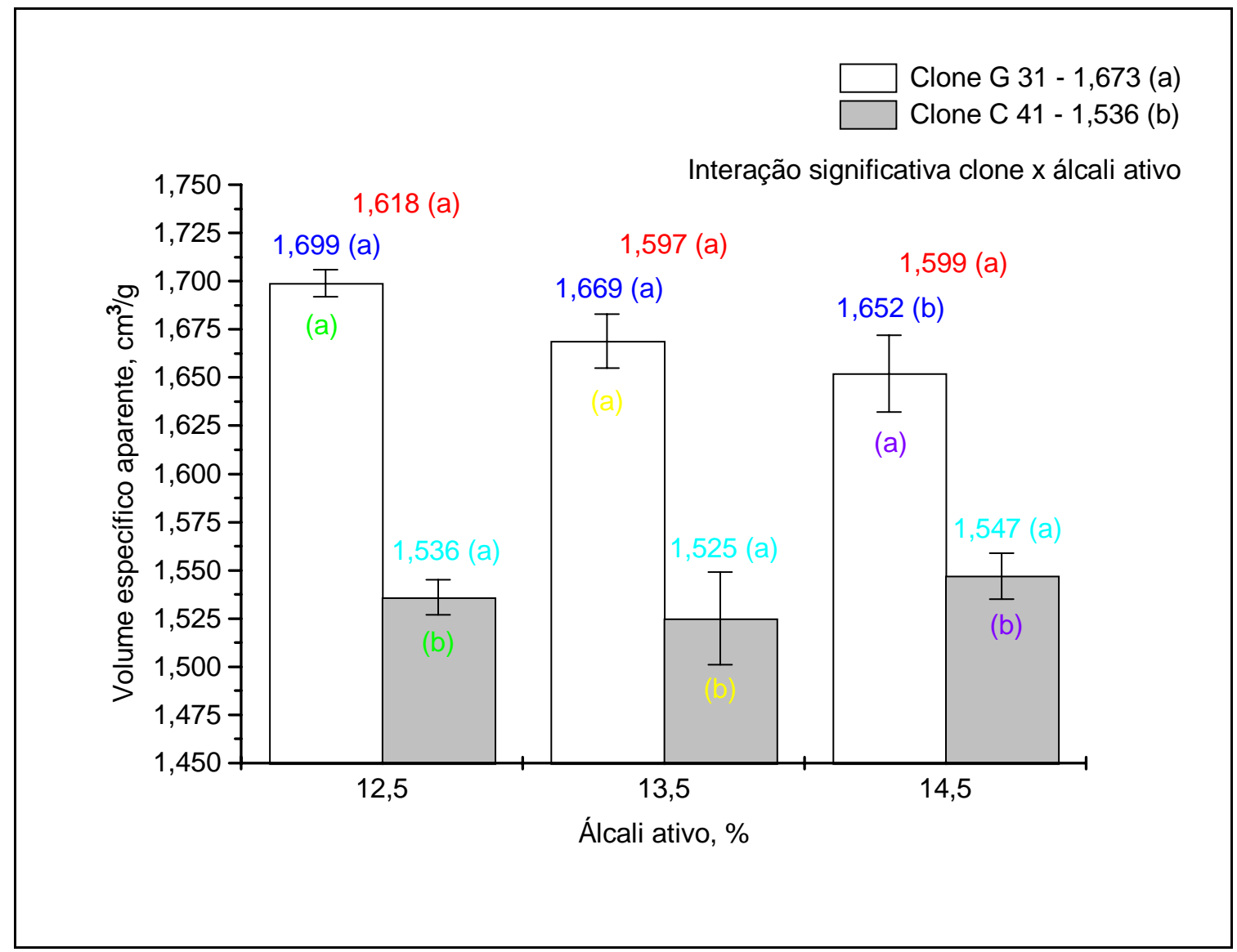

Figura 41 - Volume específico aparente para índice de tração de 70 N.m/g

Conforme pode ser notado na Figura 41, o Teste de Tukey mostrou que a análise de clone dentro de álcali ativo revelou comportamento diferenciado. A diferença entre médias de clones dentro de álcali ativo decresceu na ordem $12,5 \%, 13,5 \%$ e 14,5\% de álcali ativo, principalmente, devido à diminuição do volume específico aparente da polpa do clone G-31. Este comportamento diferenciado dos clones nas cargas de álcali ativo foi detectado como interação 
significativa clone $x$ álcali ativo na análise de variância geral. A análise de álcali ativo dentro de clone revela comportamento diferente para os clones. O volume específico aparente em função do álcali ativo mostrou tendência de queda linear para a polpa do clone G-31 e permaneceu praticamente constante para a polpa do clone C-41 (não significativo). Isto significa que o clone G-31 foi mais sensível à variação de álcali ativo que o clone C-41 em relação ao volume específico aparente. Os fatores que mais influenciaram no volume específico aparente, em ordem decrescente, foram clone e interação clone $x$ álcali ativo.

A polpa do clone G-31 (menor densidade básica) produziu folhas com maior volume específico aparente quando comparada com a polpa do clone C41 (maior densidade básica) em índice de tração de 70 N.m/g. Este comportamento pode ser atribuído ao menor número de revoluções no PFI requerido para a polpa do clone G-31 (menor colapsamento das fibras). A elevação do álcali ativo dentro do clone G-31 promoveu decréscimo no volume específico aparente porque necessitou de número de revoluções mais elevados no PFI. Este comportamento não foi observado para o clone C-41.

A Figura 42 mostra o peso específico aparente para índice de tração de 70 N.m/g. A análise de variância geral mostrou efeito significativo, em ordem decrescente, para clone e interação clone $x$ álcali ativo no peso específico aparente. A interação significativa indica que o comportamento dos clones depende das cargas de álcali ativo. Neste caso, as médias gerais não podem ser comparadas. A análise de variância de álcali ativo dentro de clone foi significativa, somente, para o clone C-41. A análise de variância de clone dentro de álcali ativo foi significativa, em ordem decrescente, para 12,5\%, 14,5\% e $13,5 \%$ de álcali ativo. 


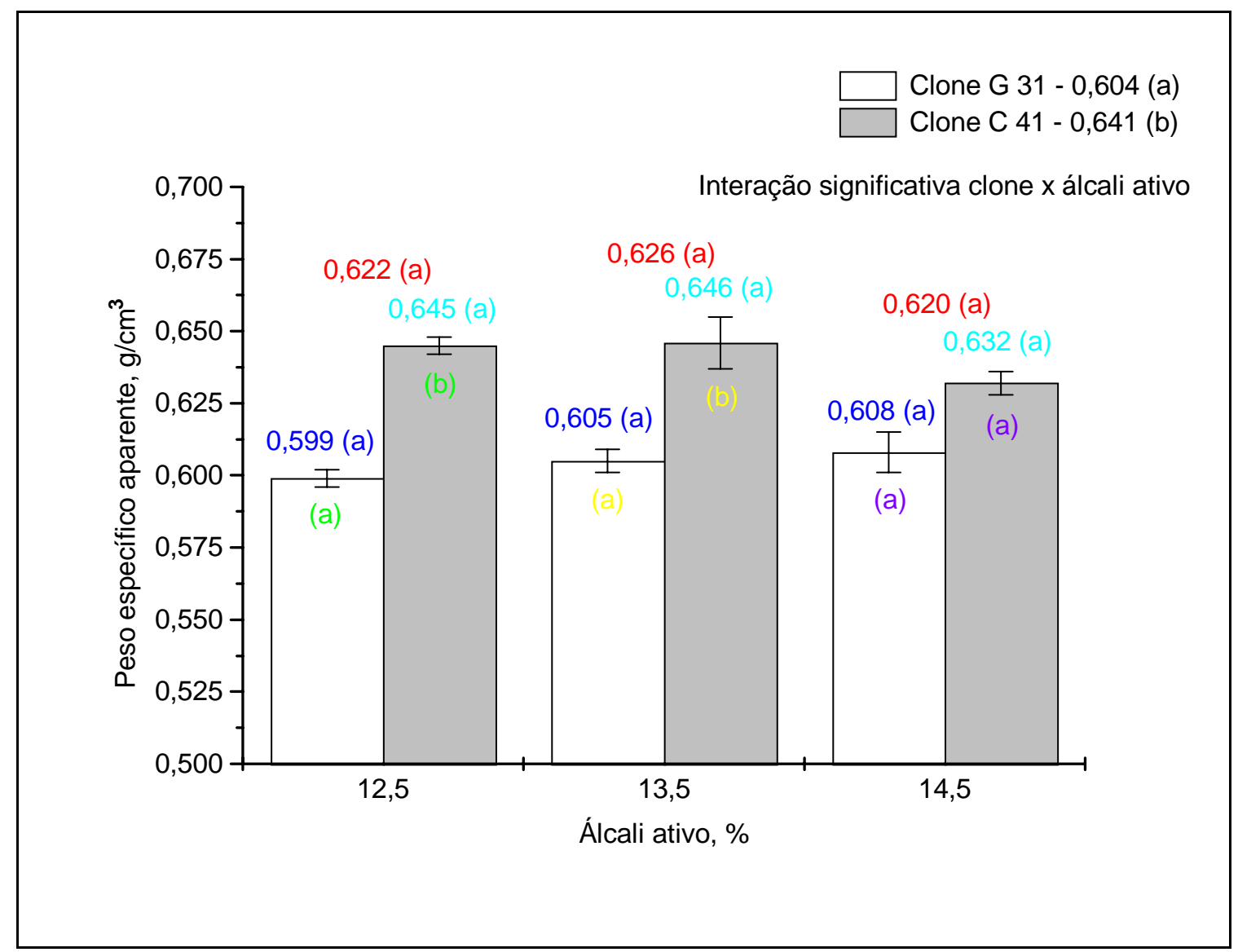

Figura 42 - Peso específico aparente para índice de tração de 70 N.m/g

Pode ser observado na Figura 42, pelo Teste de Tukey, que a análise de clone dentro de álcali ativo mostrou comportamento diferenciado e isto foi detectado como interação significativa clone $\mathrm{x}$ álcali ativo na análise de variância geral. A polpa do clone G-31 (menor densidade básica) produziu folhas com menor peso específico aparente quando comparada com a polpa do clone C-41 (maior densidade básica) em índice de tração de 70 N.m/g. Este comportamento pode ser atribuído ao menor número de revoluções no $\mathrm{PFI}$ requerido para a polpa do clone G-31.

Os fatores que mais influenciaram no peso específico aparente, em ordem decrescente, foram clone e interação clone $\mathrm{x}$ álcali ativo. 
O peso específico aparente está associado à habilidade de consolidação da estrutura do papel e tende a aumentar com a intensidade do refino, devido ao colapsamento das fibras e produção de finos.

A Figura 43 mostra o alongamento para índice de tração de 70 N.m/g. A análise de variância geral mostrou efeito significativo, em ordem decrescente, para clone e interação clone $\mathrm{x}$ álcali ativo no alongamento. A interação significativa indica que o comportamento dos clones depende das cargas de álcali ativo. Neste caso, as médias gerais não podem ser comparadas. A análise de variância de álcali ativo dentro de clone foi significativa, somente, para o clone C-41. A análise de variância de clone dentro de álcali ativo foi significativa, em ordem decrescente, para 13,5\%, 12,5\% e 14,5\% de álcali ativo.

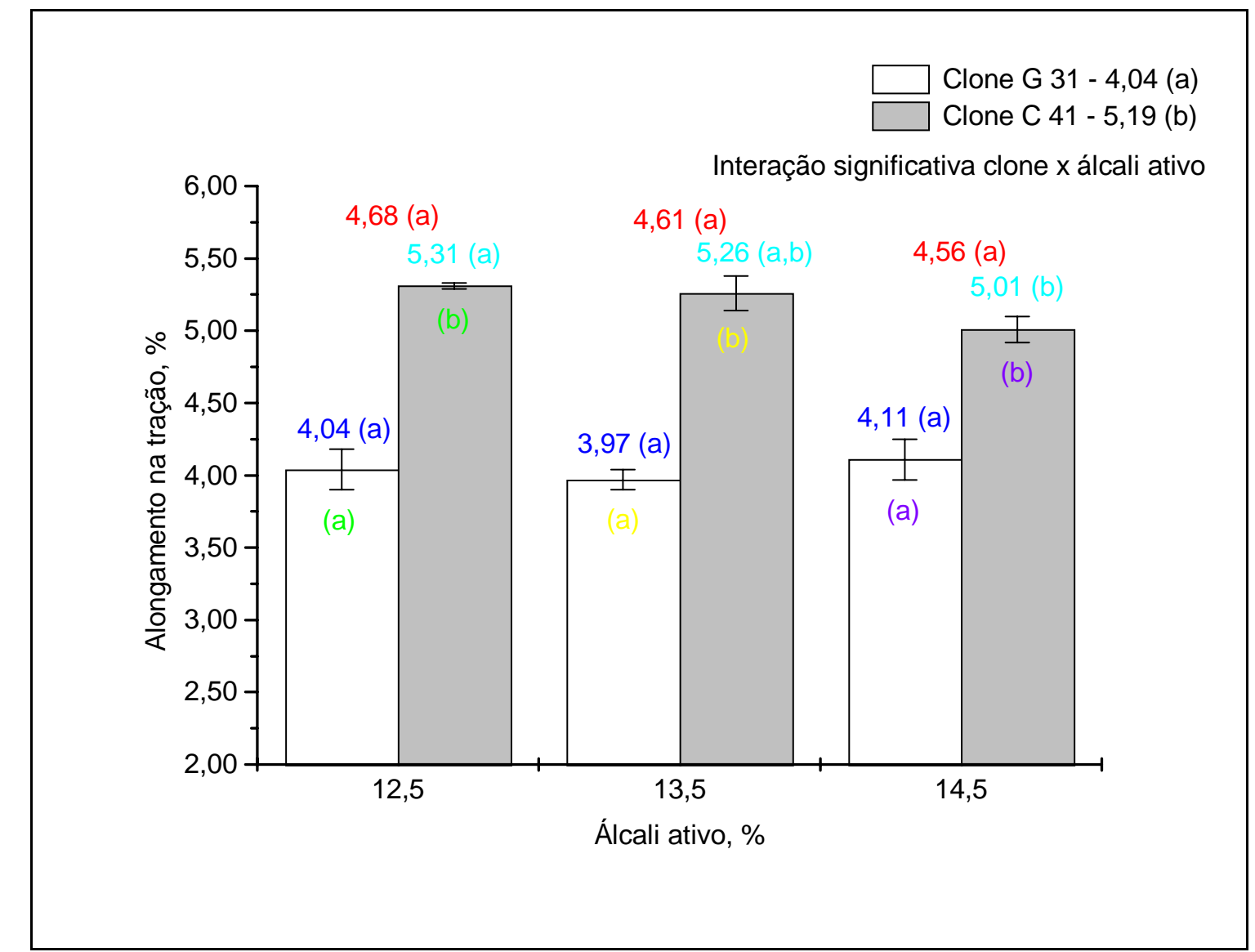

Figura 43 - Alongamento para índice de tração de 70 N.m/g 
A Figura 43 mostra, através do Teste de Tukey, que a análise de clone dentro de álcali ativo mostrou comportamento diferenciado e foi detectado como interação significativa clone $x$ álcali ativo na análise de variância geral. A análise de álcali ativo dentro de clone mostrou decréscimo do alongamento com a elevação da carga de álcali ativo somente para a polpa do clone C-41. A polpa do clone C-41 apresentou maior alongamento quando comparada com a polpa do clone G-31 em índice de tração de 70 N.m/g devido ao maior nível de refino. Os fatores mais influentes no alongamento foram clone e interação clone $\mathrm{x}$ álcali ativo.

A Figura 44 mostra o índice de energia absorvida na tração para índice de tração de 70 N.m/g. A análise de variância geral mostrou efeito significativo, em ordem decrescente, para clone e álcali ativo no índice de energia absorvida na tração. A análise de variância de álcali ativo dentro de clone foi significativa, somente, para o clone C-41. A análise de variância de clone dentro de álcali ativo foi significativa, em ordem decrescente, para 13,5\% e 12,5\% de álcali ativo.

Conforme pode ser notado na Figura 44, o Teste de Tukey mostrou que a análise de clone dentro de álcali ativo revelou maior índice de energia absorvida na tração para a polpa do clone C-41 sendo significativo para 13,5\% e 12,5\% de álcali ativo. A análise de álcali ativo dentro de clone mostrou decréscimo do índice de energia absorvida na tração com a elevação da carga de álcali ativo somente para a polpa do clone C-41. Os fatores mais importantes no índice de energia absorvida na tração foram clone e álcali ativo. 


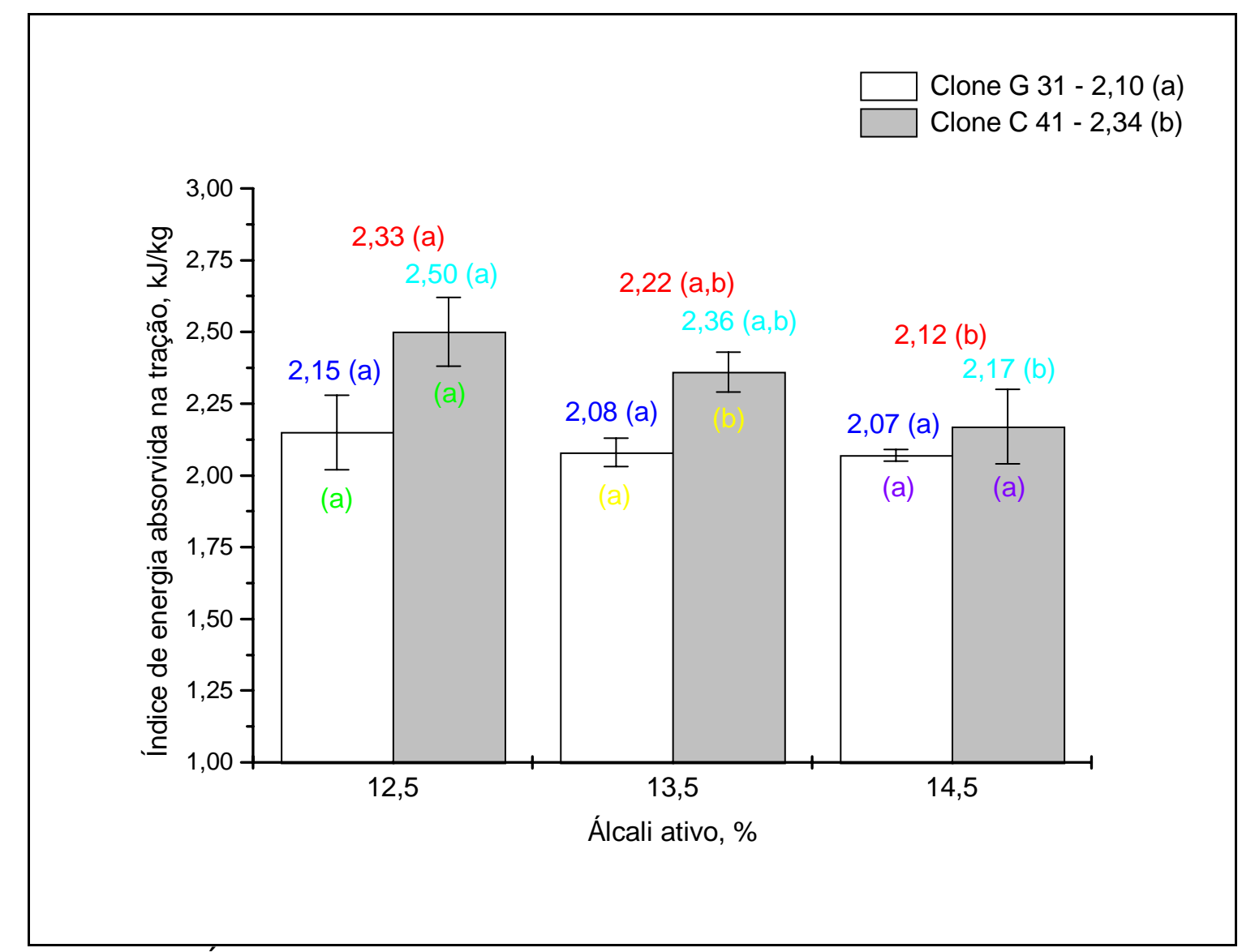

Figura 44 - Índice de energia absorvida na tração para índice de tração de 70 N.m/g

A Figura 45 mostra o índice de rigidez na tração para índice de tração de 70 N.m/g. A análise de variância geral mostrou efeito significativo, em ordem decrescente, para clone e álcali ativo no índice de rigidez na tração. A análise de variância de álcali ativo dentro de clone foi significativa, somente, para o clone C-41. A análise de variância de clone dentro de álcali ativo foi significativa, em ordem decrescente, para 14,5\%, 13,5\% e 12,5\% de álcali ativo.

Conforme mostra a Figura 45, através do Teste de Tukey, a análise de clone dentro de álcali ativo mostrou maior índice de rigidez na tração para a polpa do clone G-31 sendo significativo para todas cargas de álcali ativo. A análise de álcali ativo dentro de clone mostrou decréscimo do índice de rigidez 
na tração com a elevação da carga de álcali ativo somente para a polpa do clone C-41. Os fatores mais importantes no índice de rigidez na tração foram clone e álcali ativo.

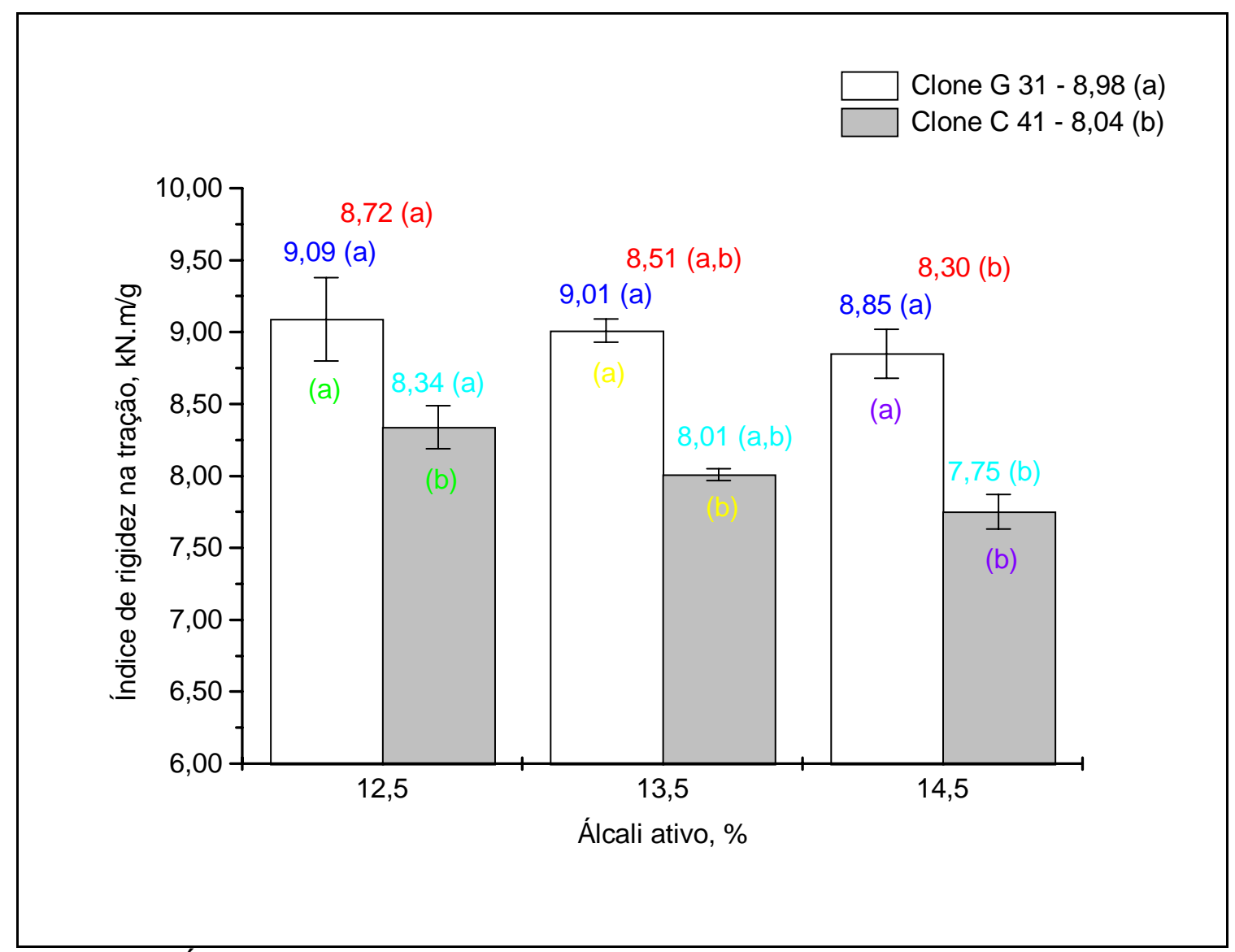

Figura 45 - Índice de rigidez na tração para índice de tração de 70 N.m/g

A Figura 46 mostra o índice de arrebentamento para índice de tração de 70 N.m/g. A análise de variância geral mostrou efeito significativo, somente, para álcali ativo. A análise de variância de álcali ativo dentro de clone foi significativa, somente, para o clone C-41. A análise de variância de clone dentro de álcali ativo foi significativa, somente, para $14,5 \%$ de álcali ativo.

Conforme revela a Figura 46, através do Teste de Tukey, a análise de clone dentro de álcali ativo não mostrou diferenças significativas nas cargas de 
álcali ativo. A análise de álcali ativo dentro de clone não mostrou diferenças significativas no índice de arrebentamento com a elevação da carga de álcali ativo para as polpas dos clones G-31 e C-41. O fator mais importante no índice de arrebentamento foi álcali ativo. É importante observar que em índice de tração constante e igual a 70 N.m/g obteve índice de arrebentamento constante, ou seja, os dois índices têm o mesmo comportamento no refino. Segundo Levlin \& Söderhjelm (1999) a resistência ao arrebentamento se relaciona matematicamente e fisicamente com a resistência a tração.

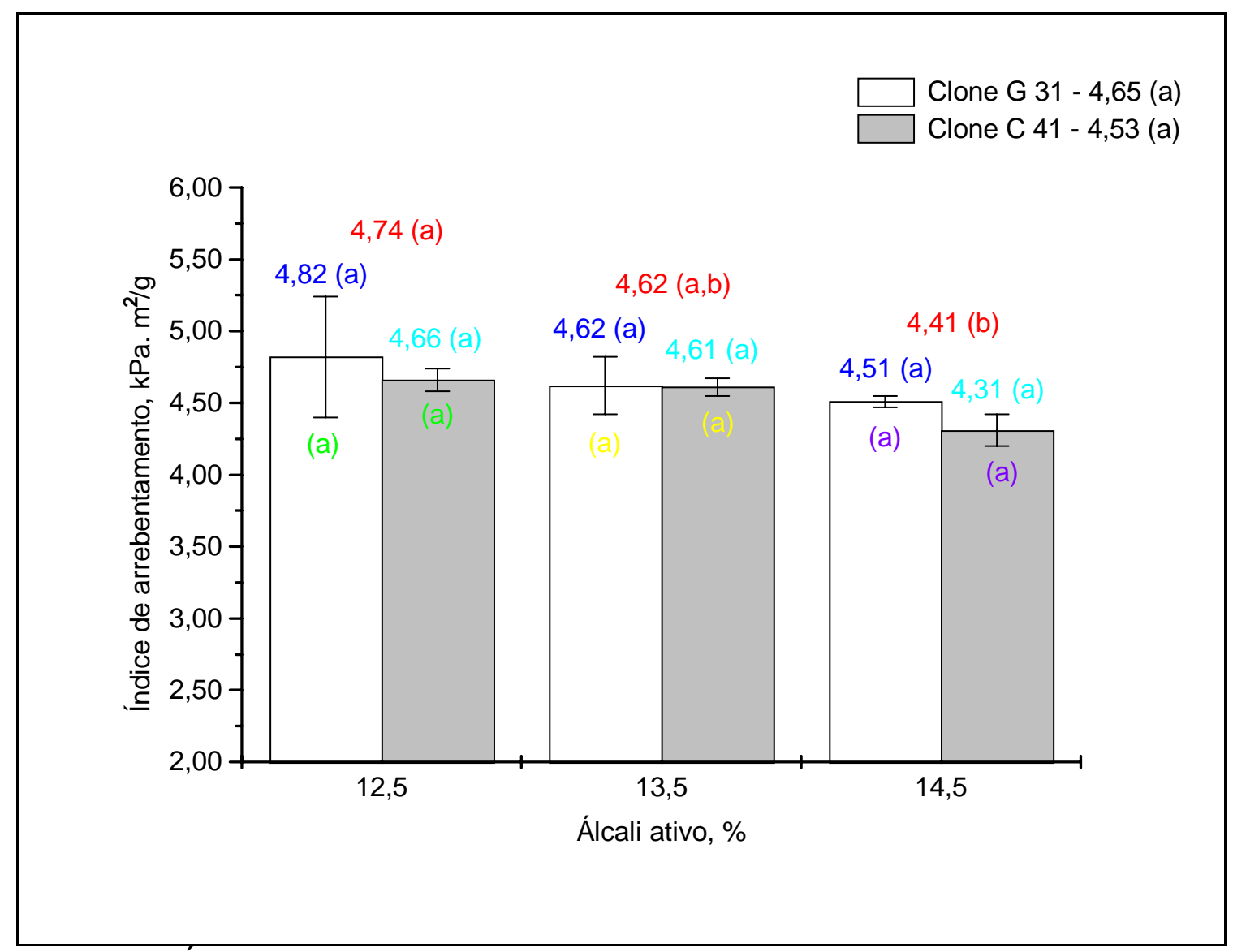

Figura 46 - Índice de arrebentamento para índice de tração de 70 N.m/g

A Figura 47 mostra o índice de rasgo para índice de tração de 70 N.m/g. A análise de variância geral mostrou efeito significativo, em ordem decrescente, 
para clone, interação clone $x$ álcali ativo e álcali ativo no índice de rasgo. A interação significativa indica que o comportamento dos clones depende das cargas de álcali ativo. Neste caso, as médias gerais não podem ser comparadas. A análise de variância de álcali ativo dentro de clone foi significativa, somente, para o clone C-41. A análise de variância de clone dentro de álcali ativo foi significativa, em ordem decrescente, para 12,5\%, 14,5\% e $13,5 \%$ de álcali ativo.

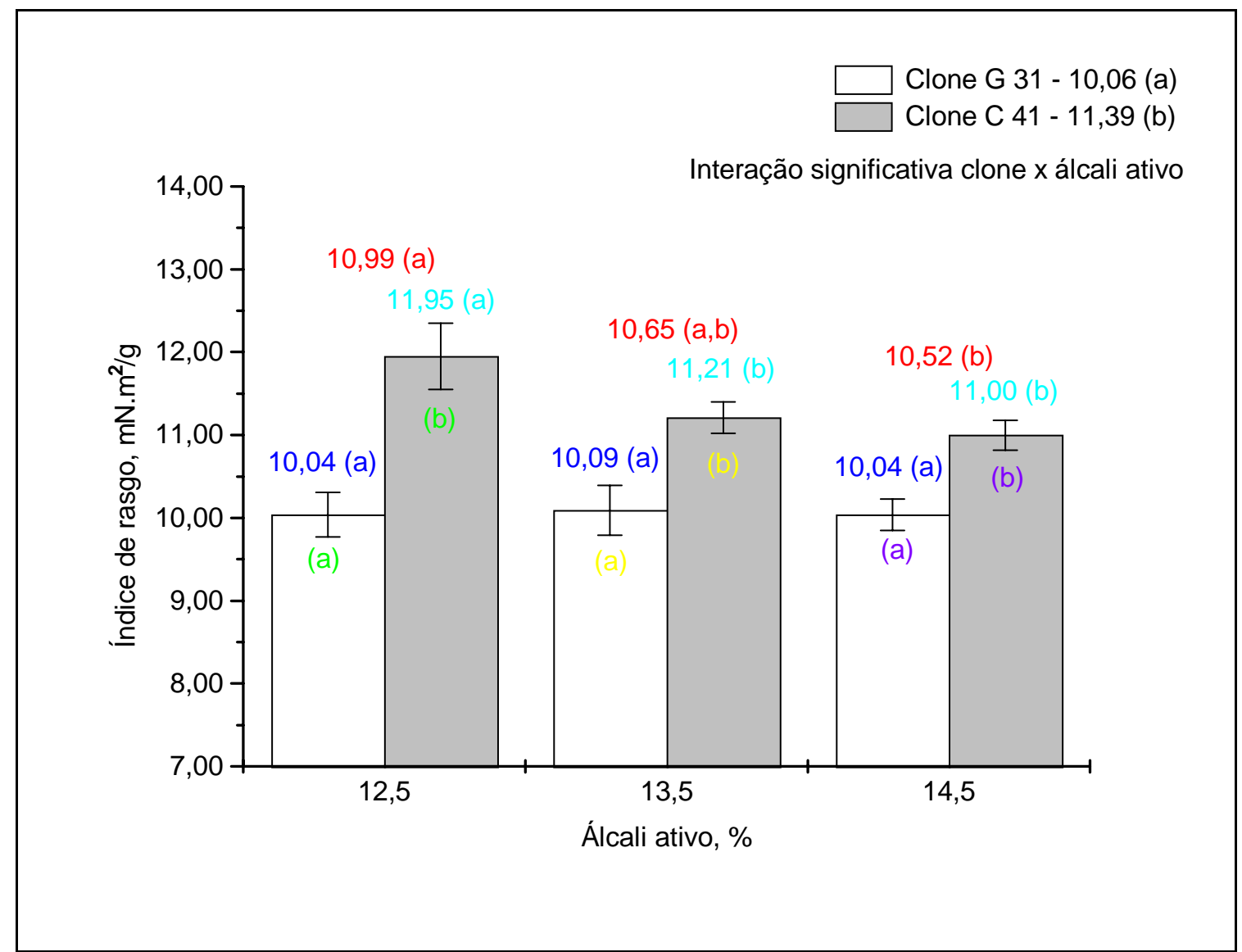

Figura 47 - índice de rasgo para índice de tração de 70 N.m/g

Conforme observado na Figura 47, o Teste de Tukey mostrou que a análise de clone dentro de álcali ativo revelou comportamento diferenciado. A diferença entre médias de clones dentro de álcali ativo decresceu na ordem 
12,5\%, 13,5\% e 14,5\% de álcali ativo, principalmente, devido à diminuição do índice de rasgo da polpa do clone C-41. Este comportamento diferenciado dos clones nas cargas de álcali ativo foi detectado como interação significativa clone $x$ álcali ativo na análise de variância geral. A análise de álcali ativo dentro de clone mostrou decréscimo do índice de rasgo com a elevação da carga de álcali ativo somente para a polpa do clone C-41. Os fatores mais importantes no índice de rasgo foram clone, interação clone $\mathrm{x}$ álcali ativo e álcali ativo.

A resistência ao rasgo depende, no mínimo, de três fatores: comprimento da fibra, resistência da fibra e grau de ligação entre fibras. O maior índice de rasgo da polpa do clone C-41 pode ser atribuído ao maior nível de refino e maior viscosidade intrínseca da celulose. A polpa do clone C-41 apresentou as seguintes viscosidades em 12,5\%, 13,5\% e 14,5\% de álcali ativo $\left(914 \mathrm{~cm}^{3} / \mathrm{g}\right.$, $\left.856 \mathrm{~cm}^{3} / \mathrm{g}, 809 \mathrm{~cm}^{3} / \mathrm{g}\right)$ e a polpa do clone G-31 $\left(837 \mathrm{~cm}^{3} / \mathrm{g}, 787 \mathrm{~cm}^{3} / \mathrm{g}, 752\right.$ $\mathrm{cm}^{3} / \mathrm{g}$ ), ou seja, sempre maior em todas cargas de álcali ativo.

A Figura 48 mostra a resistência ao ar para índice de tração de 70 N.m/g. A análise de variância geral mostrou efeito significativo, em ordem decrescente, para álcali ativo, clone e interação clone $x$ álcali ativo na resistência ao ar. A interação significativa indica que o comportamento dos clones depende das cargas de álcali ativo. Neste caso, as médias gerais não podem ser comparadas. A análise de variância de álcali ativo dentro de clone foi significativa, em ordem decrescente, para o clone C-41 e clone G-31. A análise de variância de clone dentro de álcali ativo foi significativa, somente, para 12,5\% de álcali ativo. 


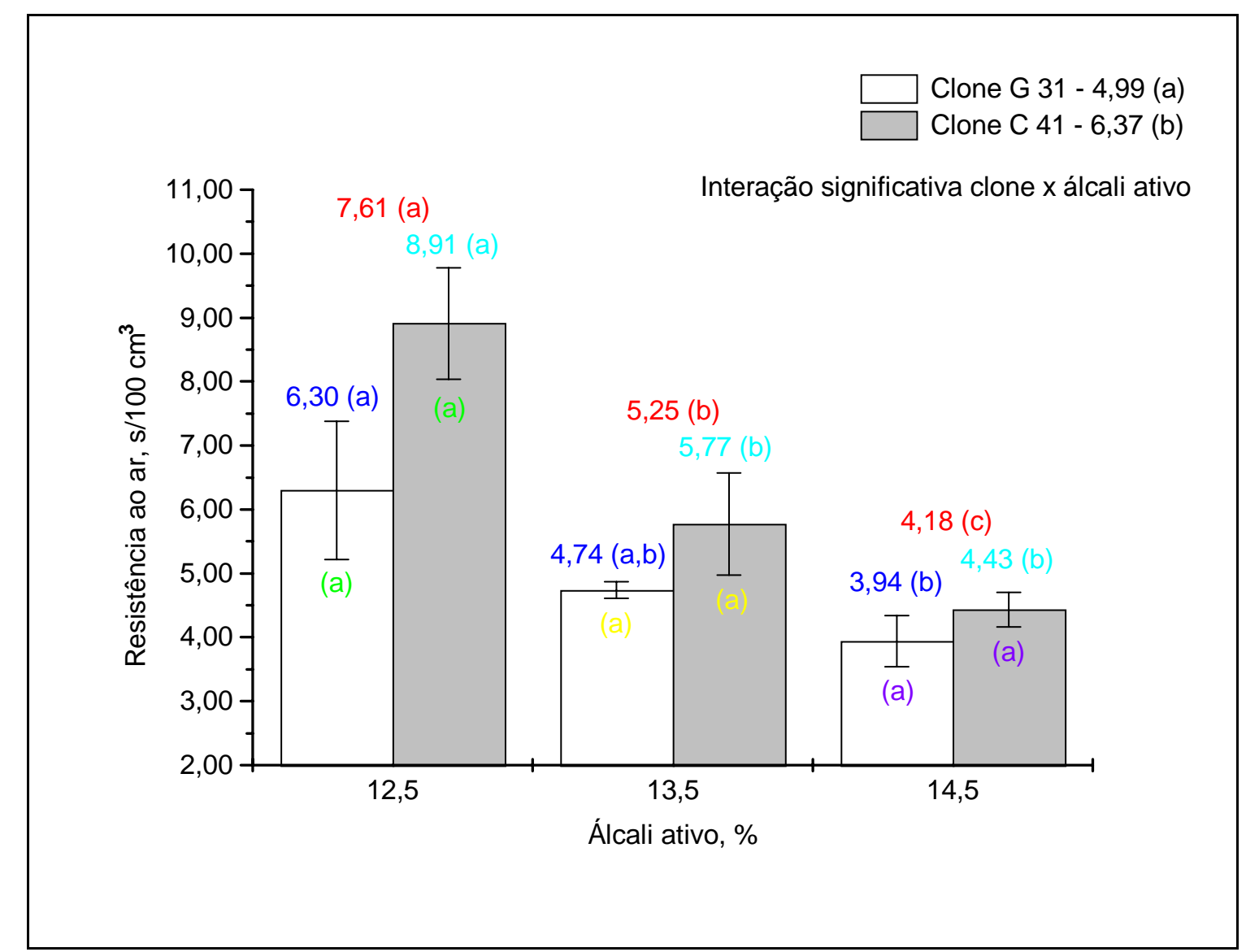

Figura 48 - Resistência ao ar para índice de tração de 70 N.m/g

Conforme pode ser notado na Figura 48, o Teste de Tukey mostrou que a análise de clone dentro de álcali ativo revelou comportamento diferenciado. A diferença entre médias de clones dentro de álcali ativo decresceu na ordem 12,5\%, 13,5\% e 14,5\% de álcali ativo, devido a diminuição da resistência ao ar mais nítida da polpa do clone C-41 em relação à polpa do clone G-31. Este comportamento diferenciado dos clones nas cargas de álcali ativo foi detectado como interação significativa clone $x$ álcali ativo na análise de variância geral. A análise de álcali ativo dentro de clone mostrou decréscimo da resistência ao ar com a elevação da carga de álcali ativo para os clones C-41 e G-31. A maior resistência ao ar da polpa do clone C-41 pode ser atribuída ao maior nível de 
refino o qual produziu folhas com maior peso específico aparente e menos porosas.

Os fatores mais importantes na resistência ao ar foram álcali ativo, clone e interação clone $x$ álcali ativo.

A resistência ao ar do papel pode ser usada como um indicador indireto da permeabilidade de um fluído na direção $Z$ do papel, bem como fornece informações do grau de refino, absorvência, peso específico aparente e filtração.

A Figura 49 mostra o índice de retenção de água para índice de tração de 70 N.m/g. A análise de variância geral mostrou efeito significativo, em ordem decrescente, para álcali ativo, clone e interação clone $\mathrm{x}$ álcali ativo no índice de retenção de água. A interação significativa indica que o comportamento dos clones depende das cargas de álcali ativo. Neste caso, as médias gerais não podem ser comparadas. A análise de variância de álcali ativo dentro de clone foi significativa, somente, para o clone C-41. A análise de variância de clone dentro de álcali ativo foi significativa, somente, para $12,5 \%$ de álcali ativo.

Conforme pode ser observado na Figura 49 através do Teste de Tukey, a análise de clone dentro de álcali ativo mostrou comportamento diferenciado. $O$ clone C-41 apresentou valores mais elevados nas cargas de 12,5\% e 14,5\% de álcali ativo em relação ao clone G-31 e valores semelhante em 13,5\% de álcali ativo. Este comportamento diferenciado dos clones nas cargas de álcali ativo foi detectado como interação significativa clone $x$ álcali ativo na análise de variância geral. A análise de álcali ativo dentro de clone mostrou decréscimo do índice de retenção de água com a elevação da carga de álcali ativo, somente, para o clone C-41. Os fatores mais importantes no índice de retenção de água foram álcali ativo, clone e interação clone $\mathrm{x}$ álcali ativo. 


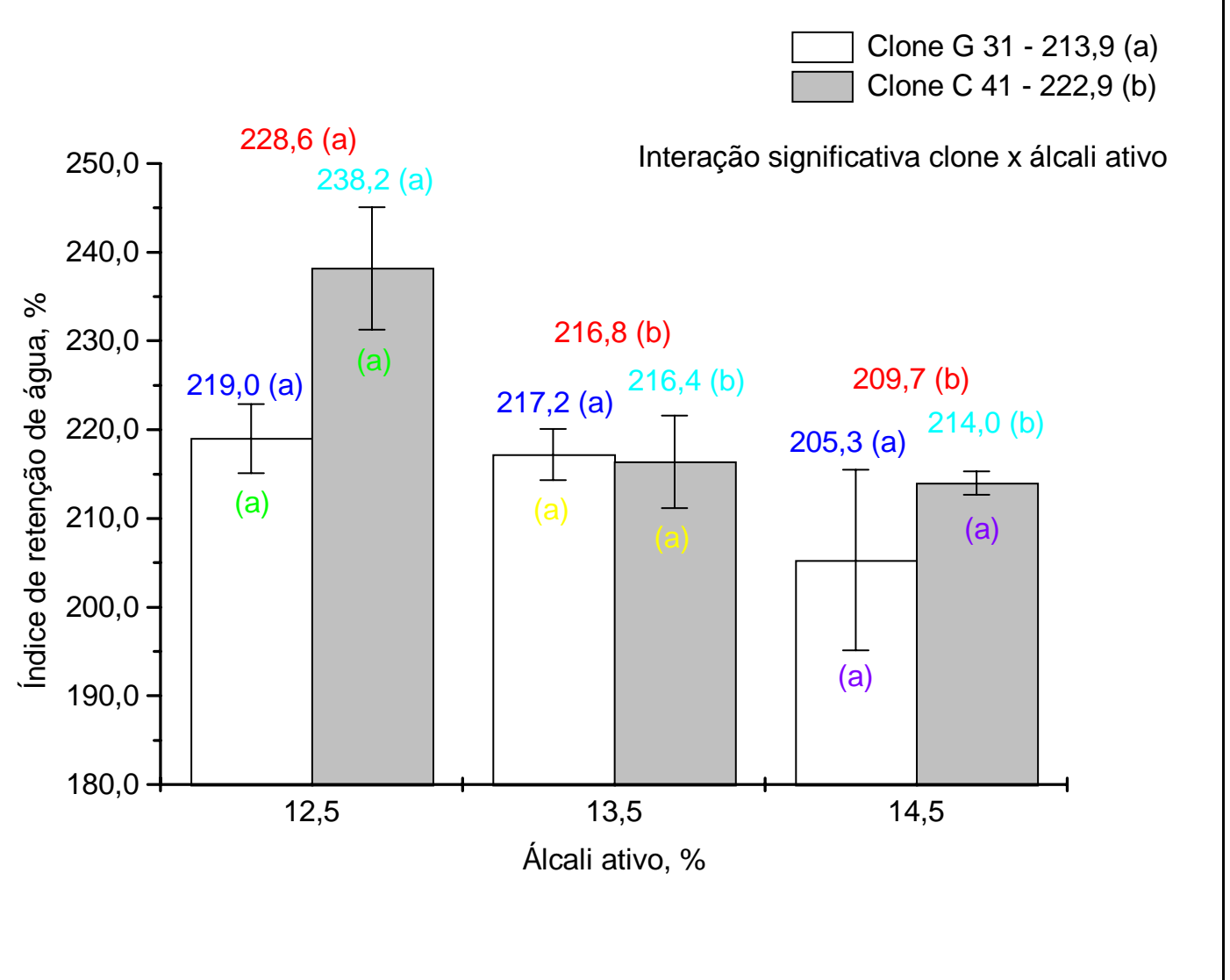

Figura 49 - Índice de retenção de água para índice de tração de 70 N.m/g

O índice de retenção de água é a medida mais usual e fácil de avaliar o inchamento das fibras. O inchamento influencia muitas fases da produção de papel como a adsorção de aditivos, a remoção de água nas seções de formação/prensagem/secagem e a ligação e consolidação da rede de fibras (Maloney et al.,1999). O maior índice de retenção de água da polpa do clone C41 pode ser atribuído ao maior nível de refino, o qual promoveu maior grau de fibrilação, maior capacidade de absorção de água, maior inchamento e por extensão maior ponto de saturação das fibras. Por outro lado, a resistência à drenagem desta água da polpa será muito mais difícil.

A Figura 50 mostra a ascensão capilar Klemm para índice de tração de 70 N.m/g. A análise de variância geral mostrou efeito significativo, somente, para 
clone na ascensão capilar Klemm. A análise de variância de álcali ativo dentro de clone foi significativa, somente, para o clone C-41. A análise de variância de clone dentro de álcali ativo foi significativa, em ordem decrescente, para 13,5\%, $14,5 \%$ e $12,5 \%$ de álcali ativo.

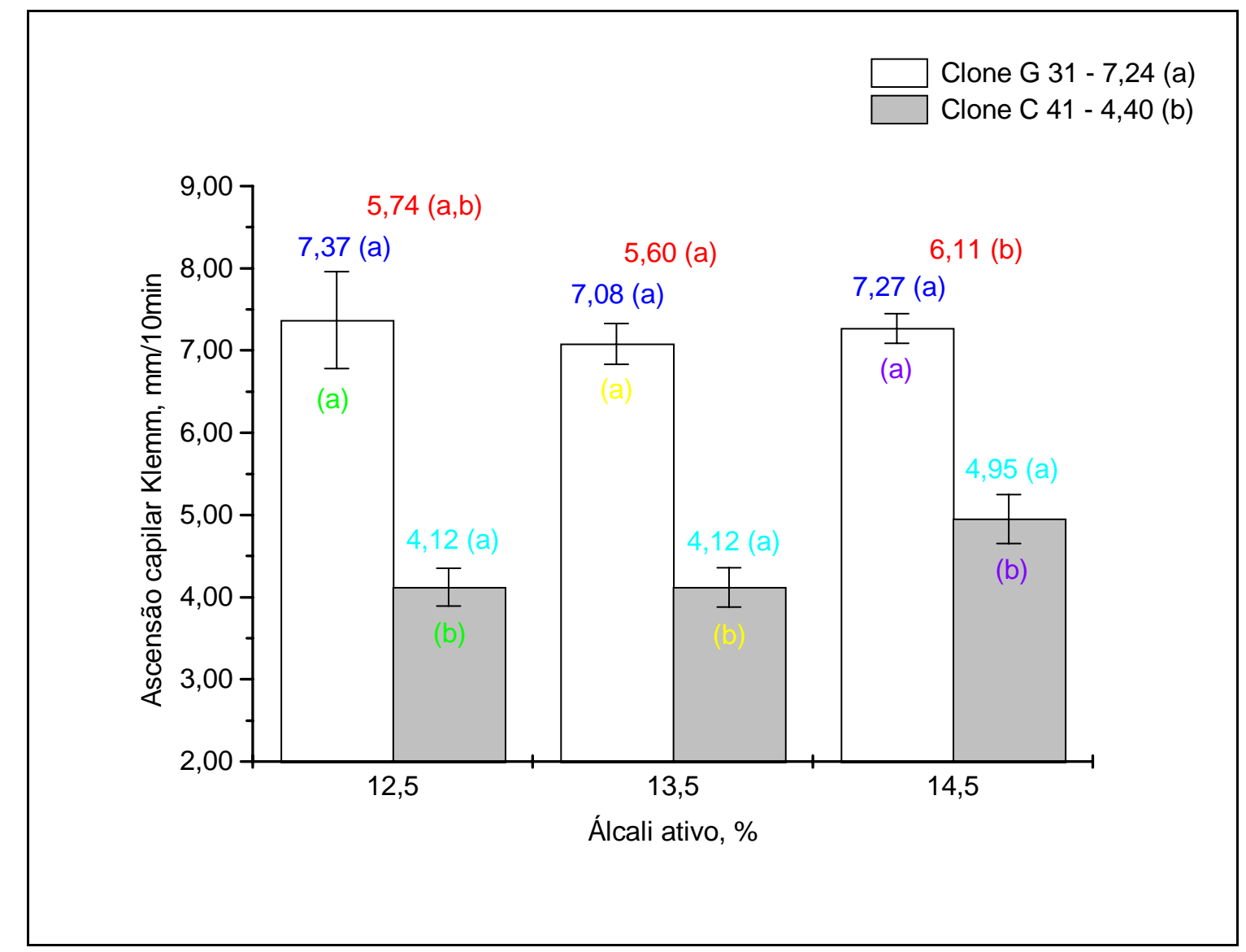

Figura 50 - Ascensão capilar Klemm para índice de tração de 70 N.m/g

O Teste de Tukey mostrou que a análise de clone dentro de álcali ativo revelou maior ascensão capilar Klemm para a polpa do clone G-31 em todas cargas de álcali ativo. A análise de álcali ativo dentro de clone não mostrou diferenças significativas para os clones. O fator mais importante na ascensão capilar Klemm foi o clone. A maior ascensão capilar Klemm da polpa do clone G- 
31 pode ser atribuída ao menor nível de refino, o qual gerou folhas com maior volume específico aparente.

A Figura 51 mostra a opacidade para índice de tração de 70 N.m/g. A análise de variância geral mostrou efeito significativo, em ordem decrescente, para clone e álcali ativo na opacidade. A análise de variância de álcali ativo dentro de clone foi significativa, somente, para o clone C-41. A análise de variância de clone dentro de álcali ativo foi significativa, em ordem decrescente, para $14,5 \%$ e $12,5 \%$ de álcali ativo.

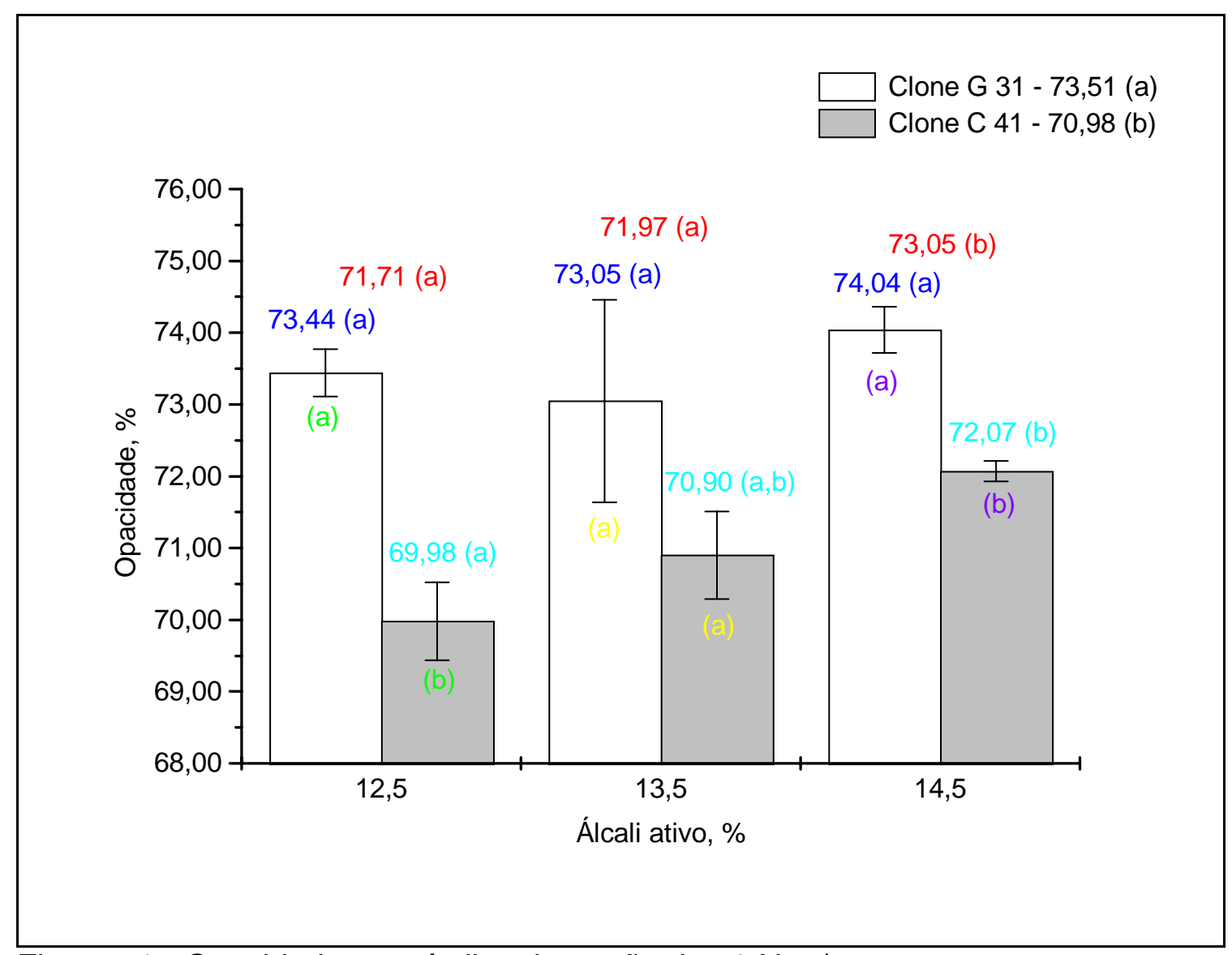

Figura 51 - Opacidade para índice de tração de 70 N.m/g

Conforme mostra a Figura 51 através do Teste de Tukey, a análise de clone dentro de álcali ativo mostrou maior opacidade para a polpa do clone G-31 
sendo significativo para 12,5\% e 14,5\% de álcali ativo. A análise de álcali ativo dentro de clone mostrou acréscimo na opacidade com a elevação da carga de álcali ativo, somente, para a polpa do clone C-41. Os fatores mais importantes na opacidade foram clone e álcali ativo. A maior opacidade da polpa do clone G31 pode ser atribuída ao menor nível de refino, o qual gerou folhas com maior volume específico aparente.

\subsection{Propriedades físico-mecânicas da polpa branqueada sem refino}

As propriedades físico-mecânicas das polpas branqueadas, sem refino, dos dois clones (G-31 e C-41) nos três níveis de álcali ativo (12,5\%, 13,5\% e $14,5 \%)$ foram analisadas quanto ao grau Schopper Riegler, volume específico aparente, peso específico aparente, índice de tração, alongamento, índice de energia absorvida na tração, índice de rigidez na tração, índice de arrebentamento, índice de rasgo, resistência ao ar, índice de retenção de água, ascensão capilar Klemm e opacidade.

A Figura 52 mostra o grau Schopper Riegler da polpa sem refino. A análise de variância geral mostrou efeito significativo, em ordem decrescente, para álcali ativo, clone e interação clone x álcali ativo no grau Schopper Riegler. A interação significativa indica que o comportamento dos clones depende das cargas de álcali ativo. Neste caso, as médias gerais não podem ser comparadas. A análise de variância de álcali ativo dentro de clone foi significativa, em ordem decrescente, para o clone C-41 e clone G-31. A análise de variância de clone dentro de álcali ativo foi significativa, somente, para 12,5\% de álcali ativo.

Conforme pode ser notado na Figura 52, o Teste de Tukey mostrou que a análise de clone dentro de álcali ativo revelou comportamento diferenciado. A polpa do clone G-31 mostrou maior grau Schopper Riegler que a polpa do clone C-41 em 12,5\% de álcali ativo. Nas cargas mais elevadas de álcali ativo, as polpas dos clones G-31 e C-41 apresentaram graus Schopper Riegler 
semelhantes. Este comportamento diferenciado dos clones nas cargas de álcali ativo foi detectado como interação significativa clone $x$ álcali ativo na análise de variância geral. A análise de álcali ativo dentro de clone mostrou elevação do grau Schopper Riegler quando do aumento da carga de álcali ativo de 12,5\% para $13,5 \%$ nos clones C-41 e G-31. Os fatores que influenciaram no grau Schopper Riegler, em ordem decrescente foram álcali ativo, clone e interação clone $\mathrm{x}$ álcali ativo.

A tendência do maior grau Schopper Riegler da polpa do clone G-31 em relação ao clone C-41 pode ser atribuída a menor "coarseness" das fibras o que confere drenagem mais lenta.

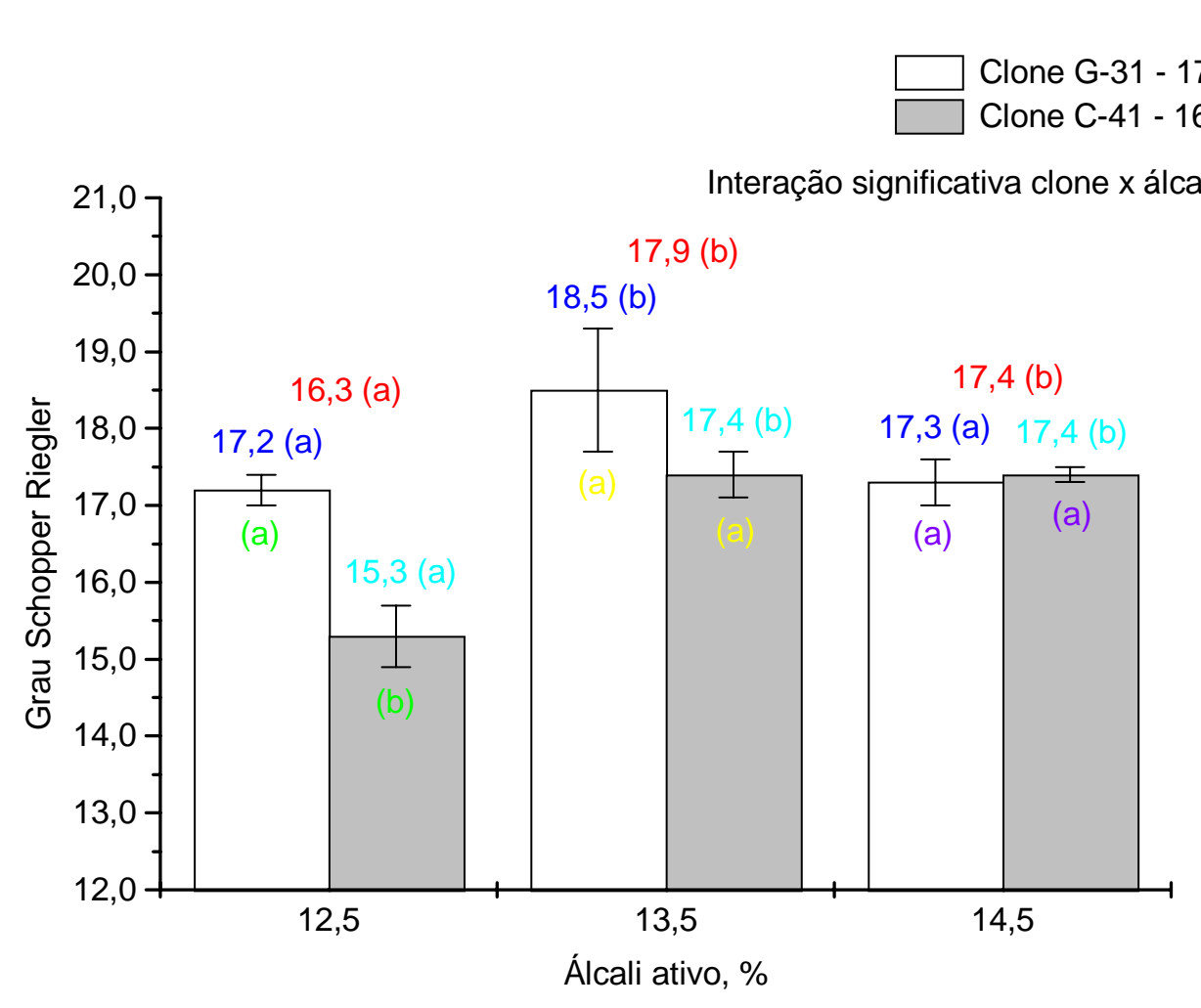

Figura 52 - Grau Schopper de polpa sem refino 
A Figura 53 mostra o volume específico aparente da polpa sem refino. A análise de variância geral mostrou efeito significativo, em ordem decrescente, para clone, álcali ativo e interação clone $\mathrm{x}$ álcali ativo no volume específico aparente. A interação significativa indica que o comportamento dos clones depende das cargas de álcali ativo. Neste caso, as médias gerais não podem ser comparadas. A análise de variância de álcali ativo dentro de clone foi significativa, somente, para o clone C-41. A análise de variância de clone dentro de álcali ativo foi significativa, em ordem decrescente, para 14,5\% e 13,5\% de álcali ativo.

De acordo com o Teste de Tukey, a análise de clone dentro de álcali ativo mostrou comportamento diferenciado. A polpa do clone C-41 mostrou maior volume específico aparente que a polpa do clone G-31 em 14,5\% e 13,5\% de álcali ativo. Na carga de 12,5\% de álcali ativo, as polpas dos clones G-31 e C-41 apresentaram volumes específicos aparente semelhantes. Este comportamento diferenciado dos clones nas cargas de álcali ativo foi detectado como interação significativa clone $x$ álcali ativo na análise de variância geral. A análise de álcali ativo dentro de clone mostrou elevação do volume específico aparente, somente, para o clone $\mathrm{C}-41$. Os fatores que influenciaram no volume específico aparente, em ordem decrescente, foram clone, álcali ativo e interação clone $x$ álcali ativo.

O volume específico aparente mais elevado da polpa do clone C-41 em relação ao clone G-31 pode ser atribuído a maior densidade básica da madeira do clone C-41 e a maior "coarseness" das fibras (fibras mais pesadas). A tendência de maior volume específico aparente com a elevação da carga alcalina pode ser explicada devido a maior remoção de componentes químicos da parede celular, a qual reduziu a largura e o diâmetro do lume da fibra (ver Figuras 27 e 28). 


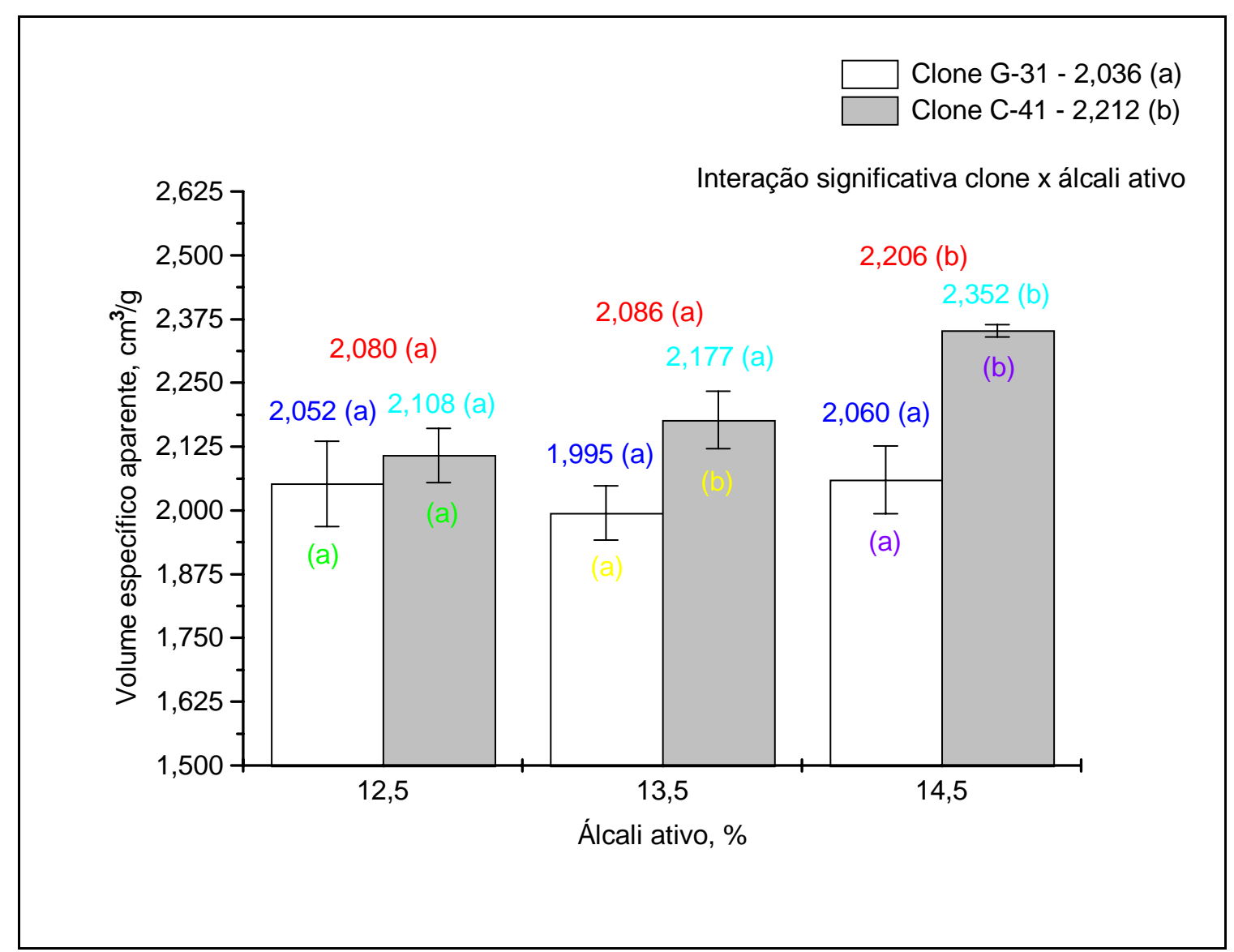

Figura 53 - Volume específico aparente da polpa sem refino

A Figura 54 mostra o peso especifico aparente da polpa sem refino. A análise de variância geral mostrou efeito significativo, em ordem decrescente, para clone, álcali ativo e interação clone $\mathrm{x}$ álcali ativo no peso específico aparente. A interação significativa indica que o comportamento dos clones depende das cargas de álcali ativo. Neste caso, as médias gerais não podem ser comparadas. A análise de variância de álcali ativo dentro de clone foi significativa, somente, para o clone C-41. A análise de variância de clone dentro de álcali ativo foi significativa, em ordem decrescente, para 14,5\% e 13,5\% de álcali ativo. 


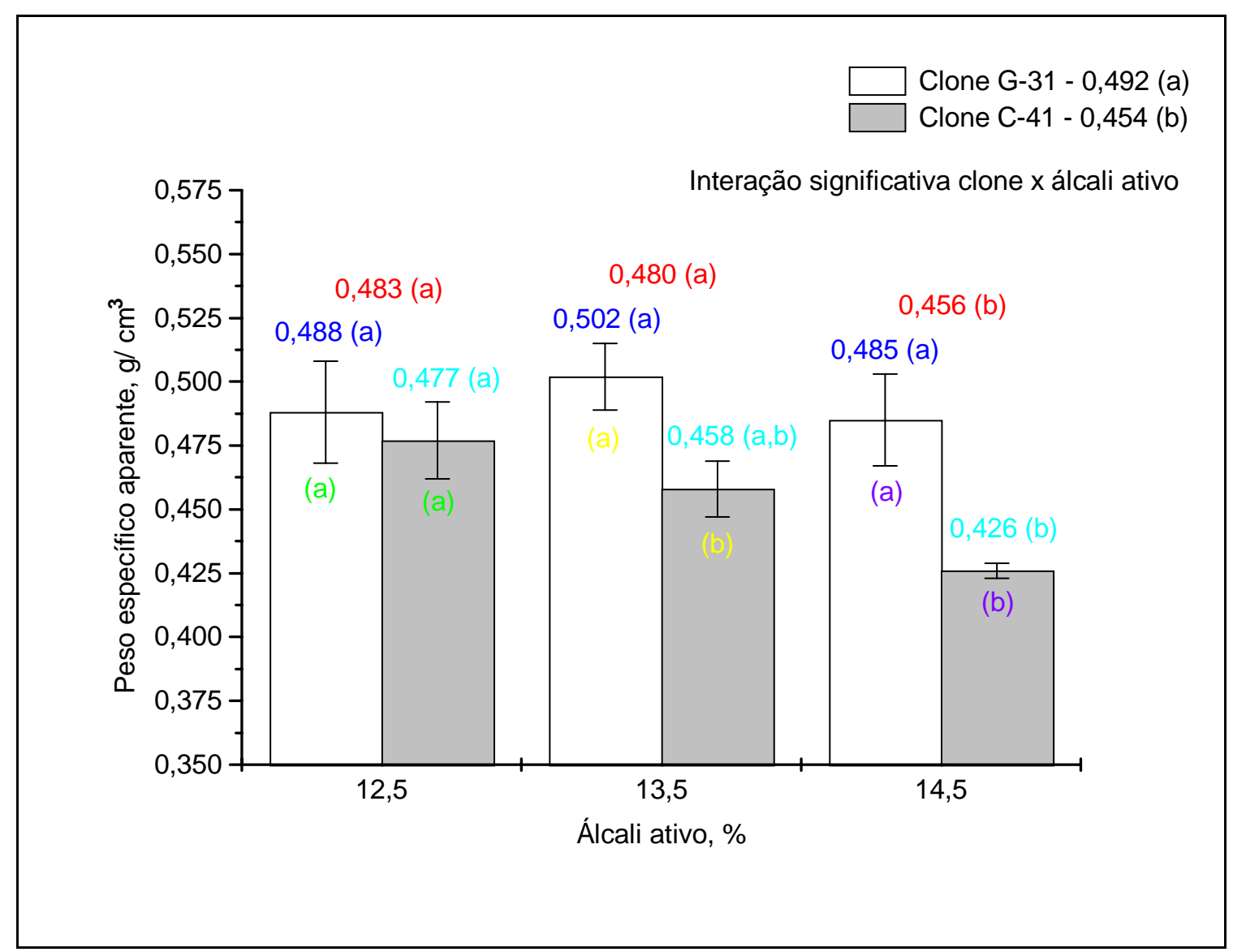

Figura 54 - Peso específico aparente da polpa sem refino

Conforme pode ser notado na Figura 54 através do Teste de Tukey, a análise de clone dentro de álcali ativo mostrou comportamento diferenciado. A polpa do clone C-41 mostrou menor peso específico aparente que a polpa do clone G-31 em 14,5\% e 13,5\% de álcali ativo. Na carga de 12,5\% de álcali ativo, as polpas dos clones G-31 e C-41 apresentaram pesos específicos aparente semelhantes. Este comportamento diferenciado dos clones nas cargas de álcali ativo foi detectado como interação significativa clone $x$ álcali ativo na análise de variância geral. A análise de álcali ativo dentro de clone mostrou diminuição do peso específico aparente, somente, para o clone C-41. Os fatores que influenciaram no peso específico aparente, em ordem decrescente foram clone, álcali ativo e interação clone $x$ álcali ativo. 
O peso específico aparente mais elevado da polpa do clone G-31 em relação ao clone C-41 pode ser atribuído a menor densidade básica da madeira do clone G-31 e a menor "coarseness" das fibras (fibras mais leves).

A Figura 55 mostra o índice de tração da polpa sem refino. A análise de variância geral mostrou efeito significativo, em ordem decrescente, para clone e álcali ativo no índice de tração. A análise de variância de álcali ativo dentro de clone foi significativa, somente, para o clone C-41. A análise de variância de clone dentro de álcali ativo foi significativa, em ordem decrescente, para 13,5\%, $14,5 \%$ e $12,5 \%$ de álcali ativo.

No Teste de Tukey, a análise de clone dentro de álcali ativo mostrou maior índice de tração para a polpa do clone G-31 sendo significativo em todas cargas de álcali ativo. A análise de álcali ativo dentro de clone não mostrou diferenças no índice de tração com a elevação da carga de álcali ativo. Os fatores mais importantes no índice de tração foram clone e álcali ativo.

A resistência à tração depende principalmente do grau de ligação entre fibras e pode ser utilizada como um método para avaliar a capacidade de ligação entre fibras. O maior índice de tração da polpa do clone G-31 pode ser atribuído ao comprimento da fibra mais elevado (clone G-31 = 0,858 $\mathrm{mm}$ e clone C-41 = 0,768 mm), o maior índice de enfeltramento da fibra (clone G-31 = $49,29 \%$ e clone C-41 $=45,14 \%$ ) e ao maior peso específico aparente da folha nas cargas de $12,5 \%, 13,5 \%$ e $14,5 \%$ de álcali ativo (clone G-31 = 0,488 g/ $\mathrm{cm}^{3}$ $0,502 \mathrm{~g} / \mathrm{cm}^{3}-0,485 \mathrm{~g} / \mathrm{cm}^{3}$ e clone C-41 = 0,477 g/cm $-0,458 \mathrm{~g} / \mathrm{cm}^{3}-0,426$ $\left.\mathrm{g} / \mathrm{cm}^{3}\right)$.

A tendência de decréscimo do índice de tração quando da elevação da carga de álcali ativo pode ser atribuída a viscosidade final da polpa branqueada. A polpa do clone C-41 apresentou as seguintes viscosidades em 12,5\%, 13,5\% e $14,5 \%$ de álcali ativo $\left(914 \mathrm{~cm}^{3} / \mathrm{g}, 856 \mathrm{~cm}^{3} / \mathrm{g}, 809 \mathrm{~cm}^{3} / \mathrm{g}\right)$ e a polpa do clone G$31\left(837 \mathrm{~cm}^{3} / \mathrm{g}, 787 \mathrm{~cm}^{3} / \mathrm{g}, 752 \mathrm{~cm}^{3} / \mathrm{g}\right)$. 


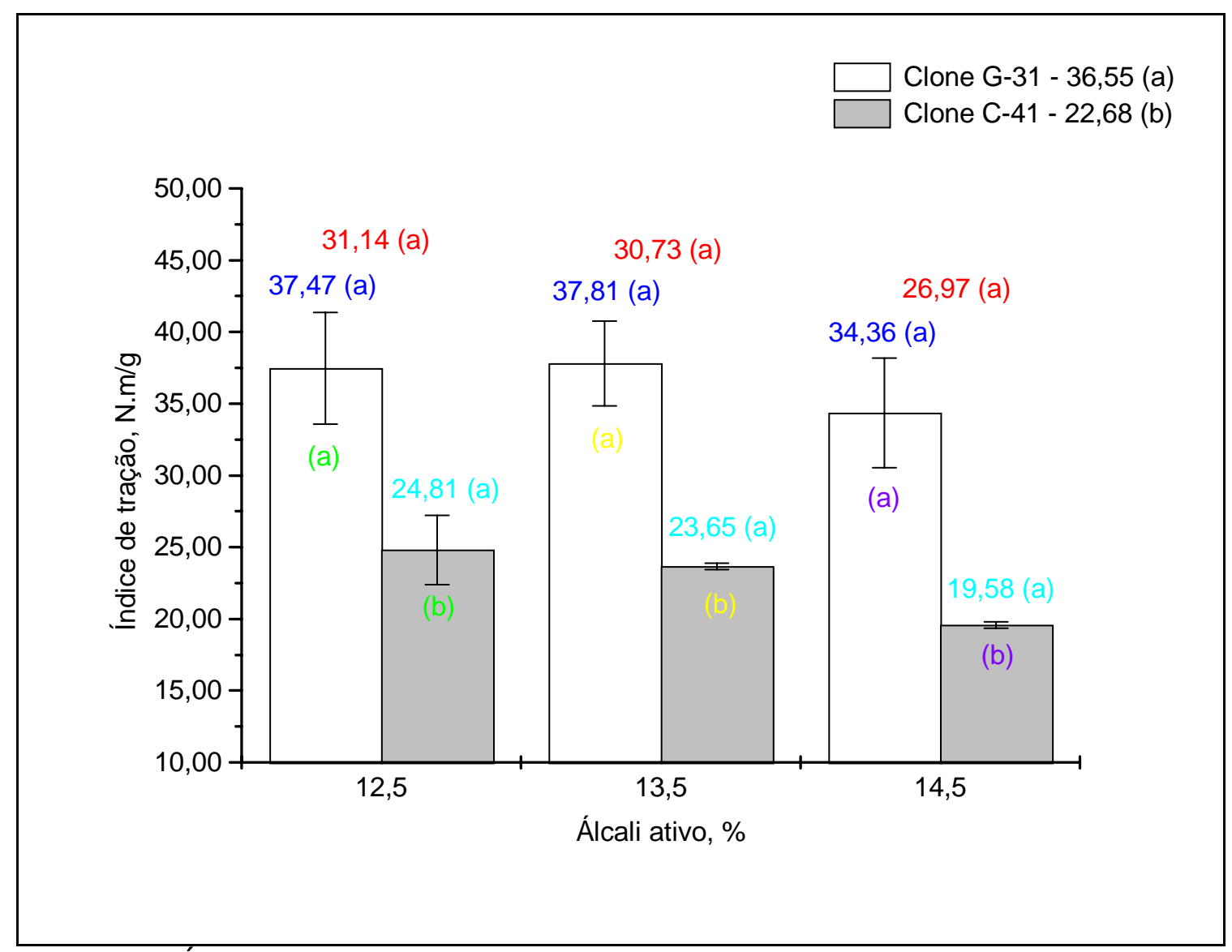

Figura 55 - Índice de tração da polpa sem refino

A Figura 56 mostra o alongamento da polpa sem refino. A análise de variância geral mostrou efeito significativo, somente, para álcali ativo no alongamento. A análise de variância de álcali ativo dentro de clone foi significativa, em ordem decrescente, para o clone G-31 e clone C-41. A análise de variância de clone dentro de álcali ativo não foi significativa para $12,5 \%$, $13,5 \%$ e $14,5 \%$ de álcali ativo.

Conforme pode ser notado na Figura 56 através do Teste de Tukey, a análise de clone dentro de álcali ativo não mostrou diferenças significativas. A análise de álcali ativo dentro de clone mostrou decréscimo do alongamento com a elevação da carga de álcali ativo. Este comportamento pode ser explicado através do decréscimo da viscosidade da celulose dentro dos clones. 


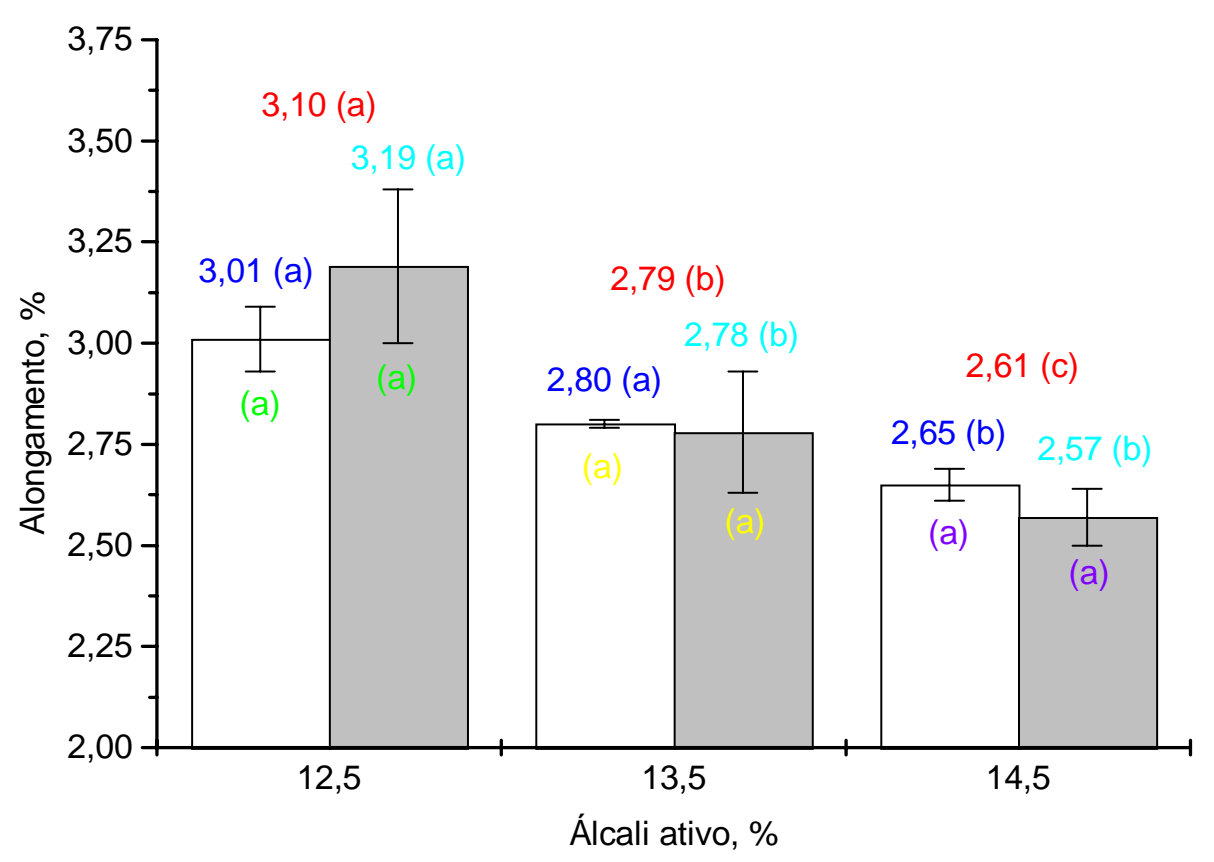

Figura 56 - Alongamento da polpa sem refino

A Figura 57 mostra o índice de energia absorvida na tração da polpa sem refino. A análise de variância geral mostrou efeito significativo, em ordem decrescente, para clone e álcali ativo no índice de energia absorvida na tração. A análise de variância de álcali ativo dentro de clone foi significativa, somente, para o clone G-31. A análise de variância de clone dentro de álcali ativo foi significativa, em ordem decrescente, para 14,5\%,13,5\% e 12,5\% de álcali ativo.

Conforme pode ser notado na Figura 57, o Teste de Tukey mostrou que a análise de clone dentro de álcali ativo revelou maior índice de energia absorvida na tração para a polpa do clone G-31 sendo significativo para 14,5\% e 13,5\% de álcali ativo. A análise de álcali ativo dentro de clone mostrou decréscimo do 
índice de energia absorvida na tração com a elevação da carga de álcali ativo, somente, para a polpa do clone G-31. Os fatores mais importantes no índice de energia absorvida na tração foram clone e álcali ativo.

A energia absorvida na tração é uma medida da habilidade do papel absorver energia e indica a durabilidade do papel quando submetido a esforços ou tensões repetitivas ou dinâmicas. A energia absorvida na tração expressa a rijeza da folha.

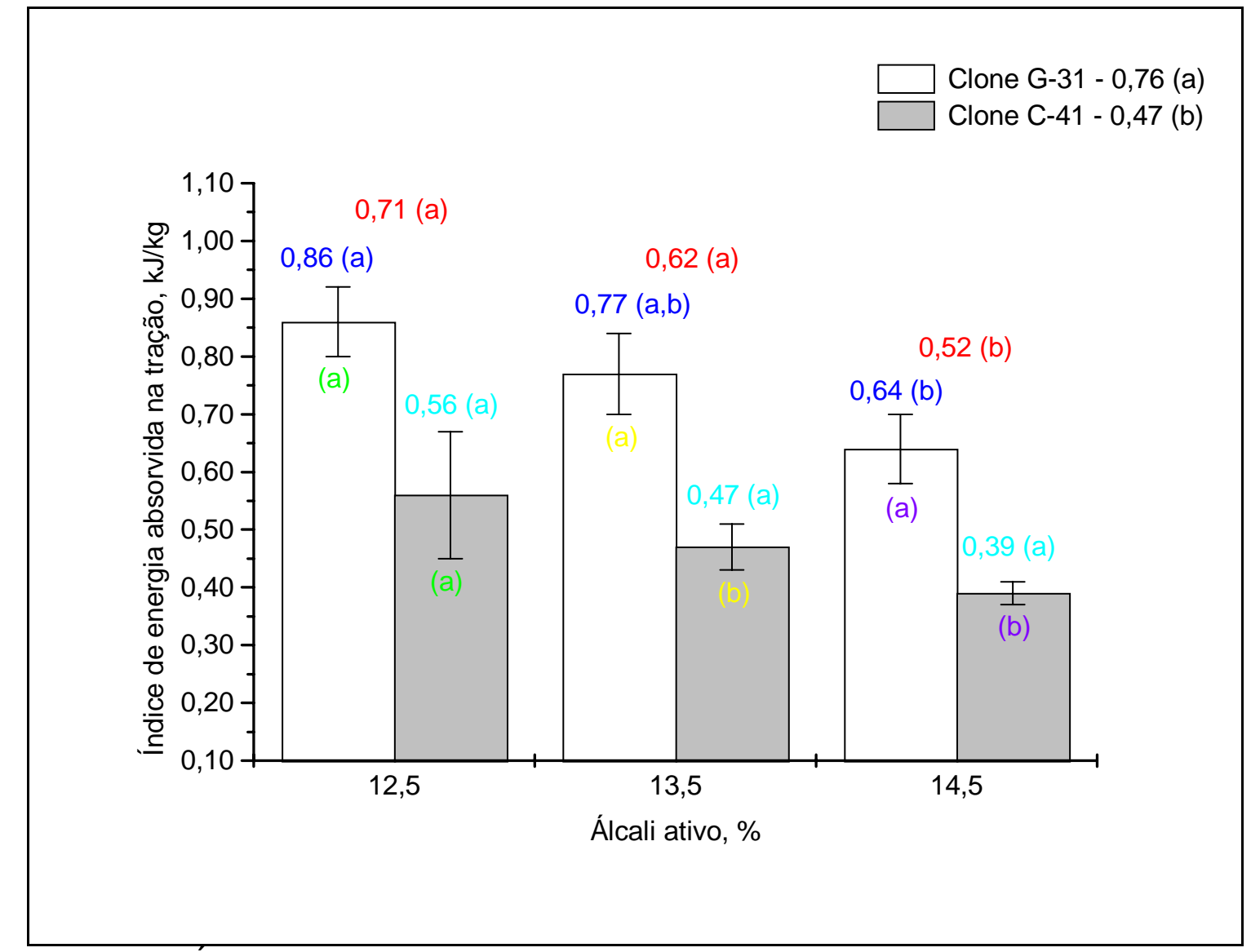

Figura 57 - Índice de energia absorvida na tração da polpa sem refino

A Figura 58 mostra o índice de rigidez na tração da polpa sem refino. A análise de variância geral mostrou efeito significativo, em ordem decrescente, para clone e álcali ativo no índice de rigidez na tração. A análise de variância de 
álcali ativo dentro de clone foi significativa, em ordem decrescente, para o clone C-41 e clone G-31. A análise de variância de clone dentro de álcali ativo foi significativa, em ordem decrescente, para 12,5\%, 14,5\% e 13,5\% de álcali ativo.

Conforme pode ser observado na Figura 58 através do Teste de Tukey, a análise de clone dentro de álcali ativo mostrou maior índice de rigidez na tração para a polpa do clone G-31 sendo significativo para todas cargas de álcali ativo. A análise de álcali ativo dentro de clone mostrou decréscimo do índice de rigidez na tração com a elevação da carga de álcali ativo para a polpa dos clones C-41 e G-31. Os fatores mais importantes no índice de rigidez na tração foram clone e álcali ativo.

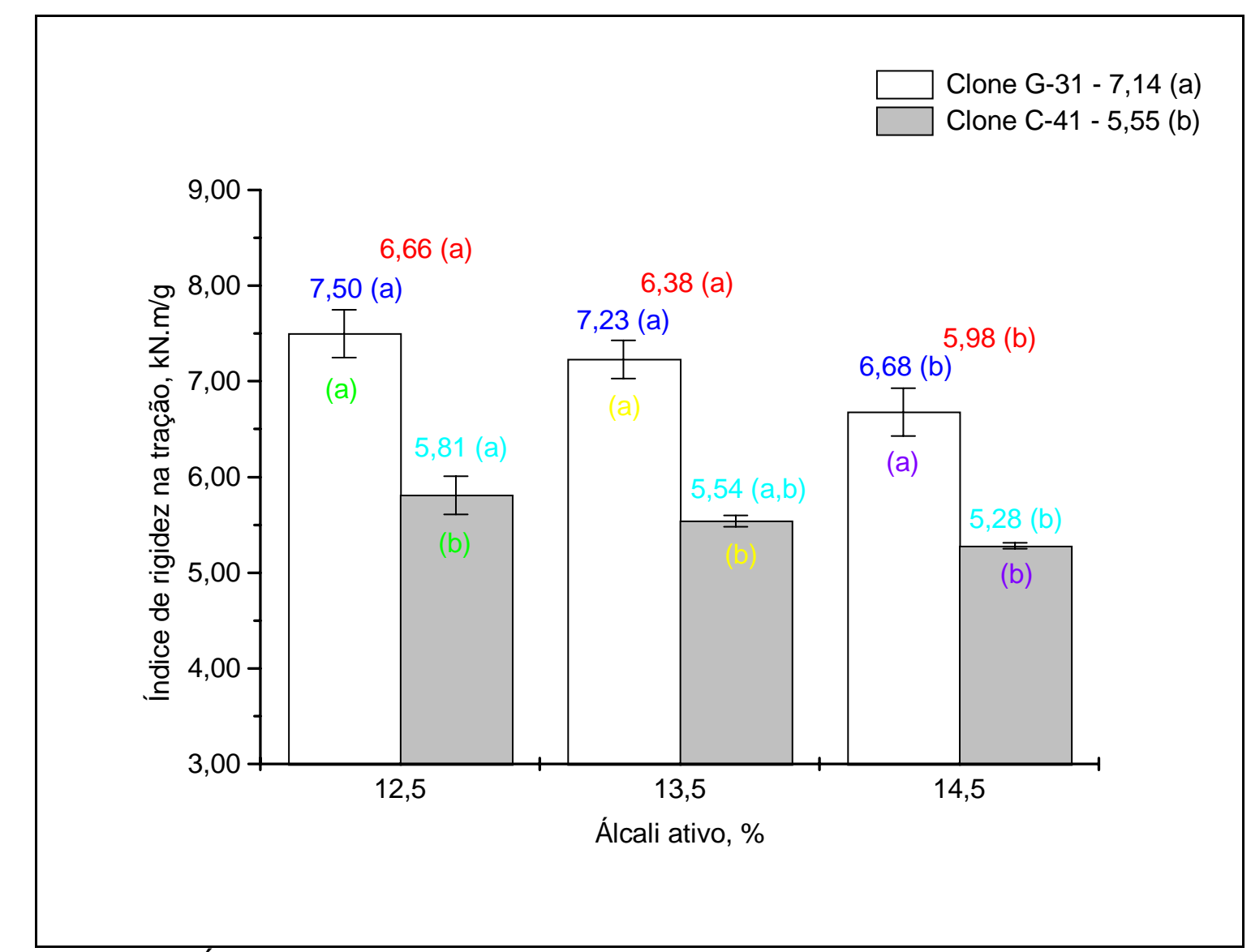

Figura 58 - Índice de rigidez na tração da polpa sem refino 
A Figura 59 mostra o índice de arrebentamento da polpa sem refino. A análise de variância geral mostrou efeito significativo, somente, para clone no índice de arrebentamento. A análise de variância de álcali ativo dentro de clone foi significativa, somente, para o clone C-41. A análise de variância de clone dentro de álcali ativo foi significativa, em ordem decrescente, para 14,5\%, 13,5\% e $12,5 \%$ de álcali ativo.

O Teste de Tukey mostrou que a análise de clone dentro de álcali ativo revelou maior índice de arrebentamento para a polpa do clone G-31 sendo significativo em todas cargas de álcali ativo. A análise de álcali ativo dentro de clone não mostrou diferenças no índice de arrebentamento com a elevação da carga de álcali ativo. Os fatores mais importantes no índice de tração foram clone e álcali ativo.

O índice de arrebentamento teve o mesmo comportamento que índice de tração (Figura 55) na polpa sem refino, pois se relacionam matematicamente e fisicamente (Levlin \& Söderhjelm, 1999). As mesmas explicações mostradas para índice de tração são válidas para o índice de arrebentamento. 


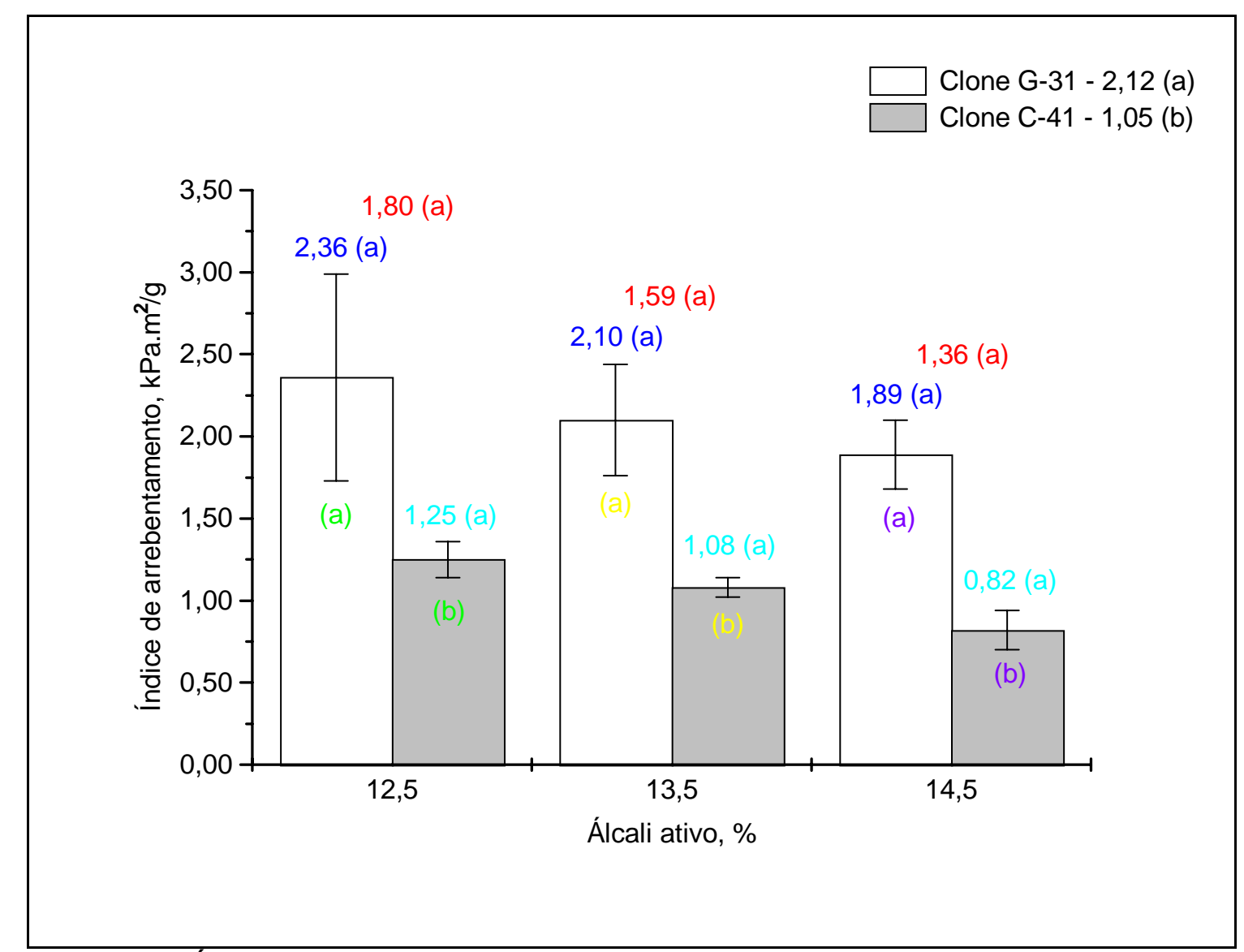

Figura 59 - Índice de arrebentamento da polpa sem refino

A Figura 60 mostra o índice de rasgo da polpa sem refino. A análise de variância geral mostrou efeito significativo, em ordem decrescente, para clone e álcali ativo no índice de rasgo. A análise de variância de álcali ativo dentro de clone foi significativa, em ordem decrescente, para o clone C-41 e clone G-31. A análise de variância de clone dentro de álcali ativo foi significativa, em ordem decrescente, para 13,5\%, 14,5\% e 12,5\% de álcali ativo.

Conforme mostra a Figura 60 através do Teste de Tukey, a análise de clone dentro de álcali ativo mostrou maior índice de rasgo para a polpa do clone G-31 sendo significativo para todas cargas de álcali ativo. A análise de álcali ativo dentro de clone mostrou decréscimo do índice de rasgo com a elevação da 
carga de álcali ativo para as polpas dos clones C-41 e G-31. Os fatores mais importantes no índice de rasgo foram clone e álcali ativo.

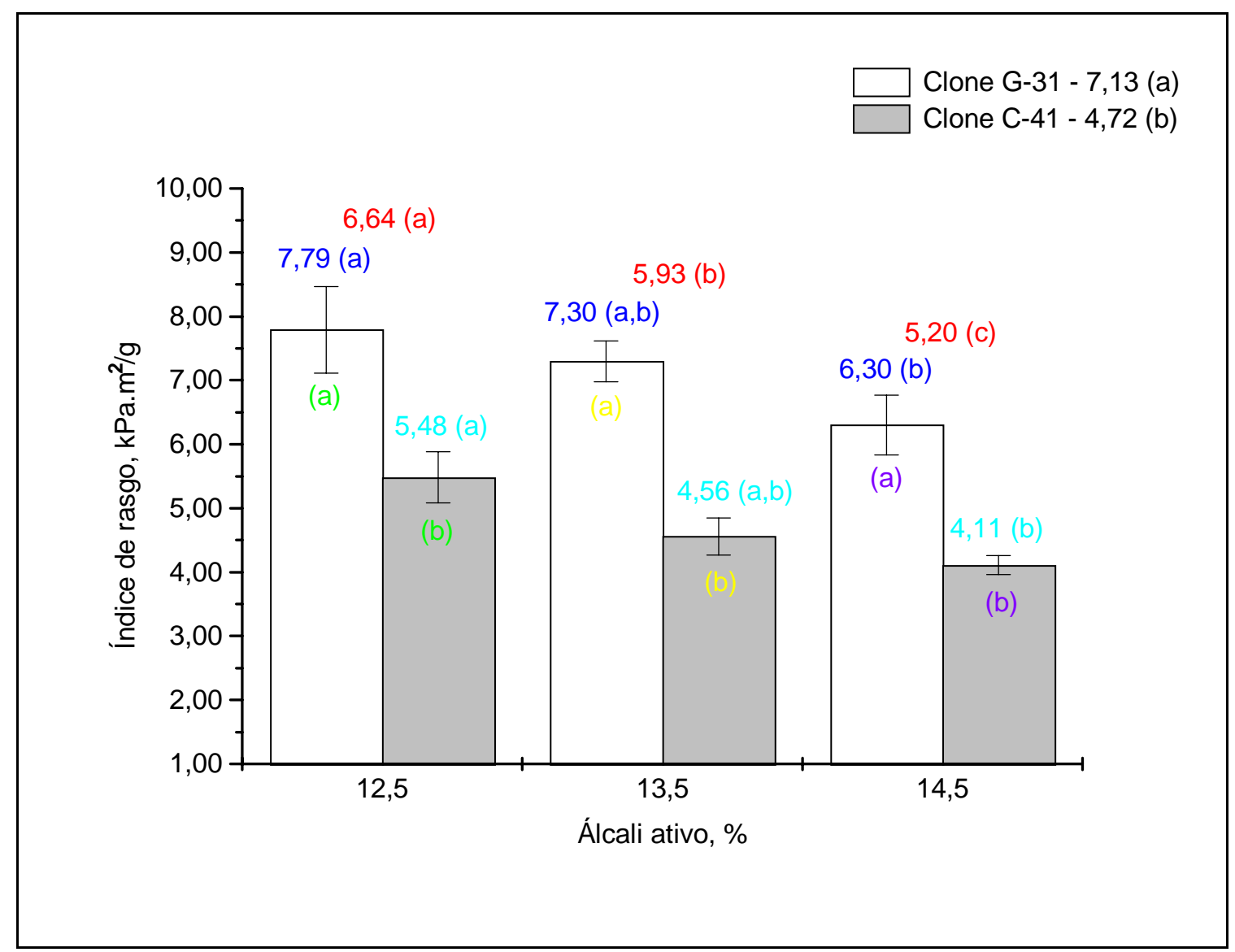

Figura 60 - índice de rasgo da polpa sem refino

A resistência ao rasgo depende, no mínimo, de três fatores: comprimento da fibra, resistência da fibra e grau de ligação entre fibras. O maior índice de rasgo da polpa do clone G-31 em relação à polpa do clone C-41 pode ser atribuído ao maior ao maior comprimento da fibra, ao maior índice de enfeltramento da fibra e ao maior peso específico aparente da folha.

O decréscimo do índice de rasgo quando da elevação da carga de álcali ativo pode ser atribuída à viscosidade final da polpa branqueada. A polpa do clone C-41 apresentou as seguintes viscosidades em 12,5\%, 13,5\% e 14,5\% de 
álcali ativo $\left(914 \mathrm{~cm}^{3} / \mathrm{g}, 856 \mathrm{~cm}^{3} / \mathrm{g}, 809 \mathrm{~cm}^{3} / \mathrm{g}\right)$ e a polpa do clone G-31 (837 $\left.\mathrm{cm}^{3} / \mathrm{g}, 787 \mathrm{~cm}^{3} / \mathrm{g}, 752 \mathrm{~cm}^{3} / \mathrm{g}\right)$.

A Figura 61 mostra a resistência ao ar da polpa sem refino. A análise de variância geral mostrou efeito significativo, somente, para clone na resistência ao ar. A análise de variância de álcali ativo dentro de clone não foi significativa para o clone G-31 e clone C-41. A análise de variância de clone dentro de álcali ativo não foi significativa para 12,5\%, 13,5\% e 14,5\% de álcali ativo.

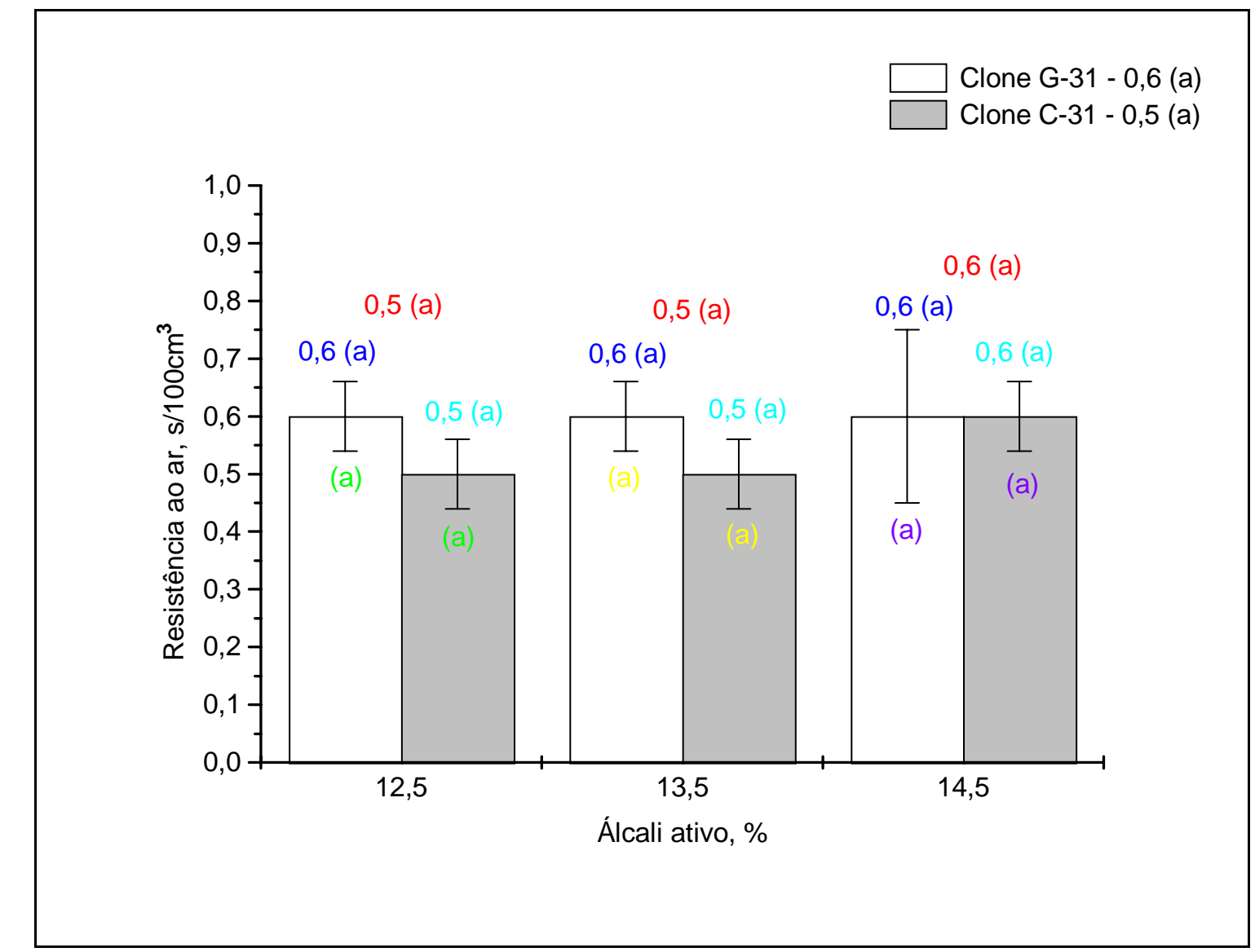

Figura 61 - Resistência ao ar da polpa sem refino

Conforme mostra a Figura 61, a análise de clone dentro de álcali ativo e a análise de álcali ativo dentro de clone não mostrou diferenças significativas para resistência ao ar da polpa sem refino. 
A Figura 62 mostra o índice de retenção de água da polpa sem refino. A análise de variância geral mostrou efeito significativo, em ordem decrescente, para clone, álcali ativo e interação clone $x$ álcali ativo no índice de retenção de água. A interação significativa indica que o comportamento dos clones depende das cargas de álcali ativo. Neste caso, as médias gerais não podem ser comparadas. A análise de variância de álcali ativo dentro de clone foi significativa, em ordem decrescente, para o clone C-41 e clone G-31. A análise de variância de clone dentro de álcali ativo foi significativa, em ordem decrescente, para $13,5 \%$ e $12,5 \%$ de álcali ativo.

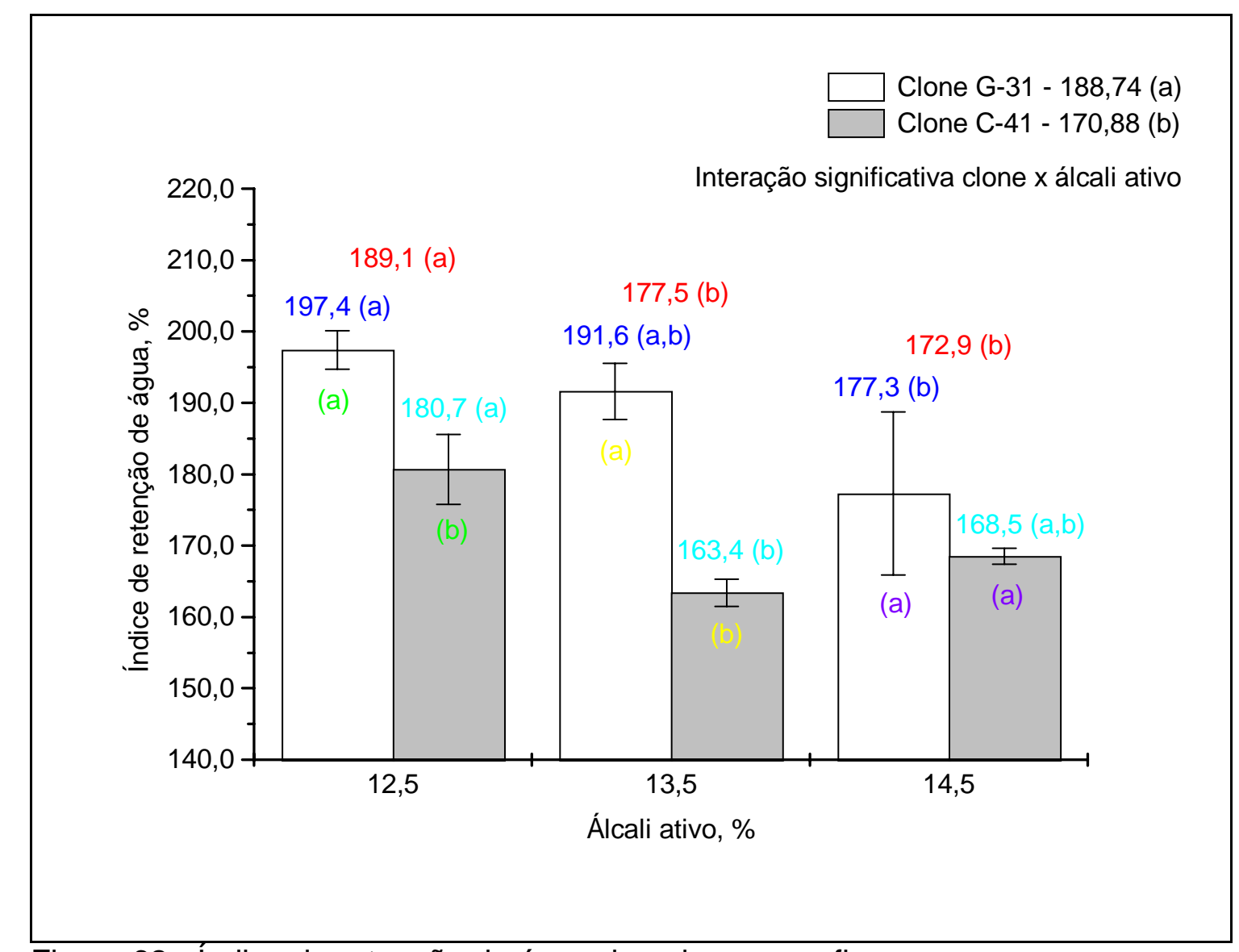

Figura 62 - Índice de retenção de água da polpa sem refino 
Conforme pode ser notado na Figura 62, o Teste de Tukey mostrou que a análise de clone dentro de álcali ativo revelou comportamento diferenciado. A polpa do clone G-31 mostrou maior índice de retenção de água que a polpa do clone C-41 em 13,5\% e 12,5\% de álcali ativo. Na carga de 14,5\% de álcali ativo, as polpas dos clones G-31 e C-41 apresentaram índices de retenção de água semelhantes. Este comportamento diferenciado dos clones nas cargas de álcali ativo foi detectado como interação significativa clone $x$ álcali ativo na análise de variância geral. A análise de álcali ativo dentro de clone mostrou diminuição do índice de retenção de água para os clones C-41 e G-31. Os fatores que influenciaram no índice de retenção de água, em ordem decrescente, foram clone, álcali ativo e interação clone x álcali ativo.

O índice de retenção de água é a medida mais usual e fácil de avaliar o inchamento das fibras. O maior índice de retenção de água da polpa do clone G31 em relação à polpa do clone C-41 pode ser atribuído a menor "coarseness" das fibras (fibras mais leves), o qual promoveu maior capacidade de absorção de água, maior inchamento e por extensão maior ponto de saturação das fibras. Por outro lado, a resistência à drenagem desta água da polpa será muito mais difícil. O decréscimo do índice de retenção de água com a elevação da carga alcalina pode ser explicado devido a maior remoção de componentes químicos da parede celular, a qual reduziu a largura e o diâmetro do lume da fibra (ver Figuras 27 e 28).

A Figura 63 mostra a ascensão capilar Klemm da polpa sem refino. A análise de variância geral mostrou efeito significativo, em ordem decrescente, para clone, álcali ativo e interação clone $x$ álcali ativo na ascensão capilar Klemm. A interação significativa indica que o comportamento dos clones depende das cargas de álcali ativo. Neste caso, as médias gerais não podem ser comparadas. A análise de variância de álcali ativo dentro de clone foi significativa, em ordem decrescente, para o clone C-41 e clone G-31. A análise de variância de clone dentro de álcali ativo foi significativa, em ordem decrescente, para $13,5 \%$ e $14,5 \%$ de álcali ativo. 
Conforme pode ser observado na Figura 63, o Teste de Tukey mostrou que a análise de clone dentro de álcali ativo revelou comportamento diferenciado. A polpa do clone C-41 mostrou maior ascensão capilar Klemm que a polpa do clone G-31 em 13,5\% e 14,5\% de álcali ativo. Na carga de 12,5\% de álcali ativo, as polpas dos clones G-31 e C-41 apresentaram ascensão capilar Klemm semelhantes. Este comportamento diferenciado dos clones nas cargas de álcali ativo foi detectado como interação significativa clone $x$ álcali ativo na análise de variância geral. A análise de álcali ativo dentro de clone mostrou elevação da ascensão capilar Klemm com o aumento da carga de álcali ativo para os clones C-41 e G-31. Os fatores que influenciaram na ascensão capilar Klemm, em ordem decrescente, foram clone, álcali ativo e interação clone $x$ álcali ativo. 


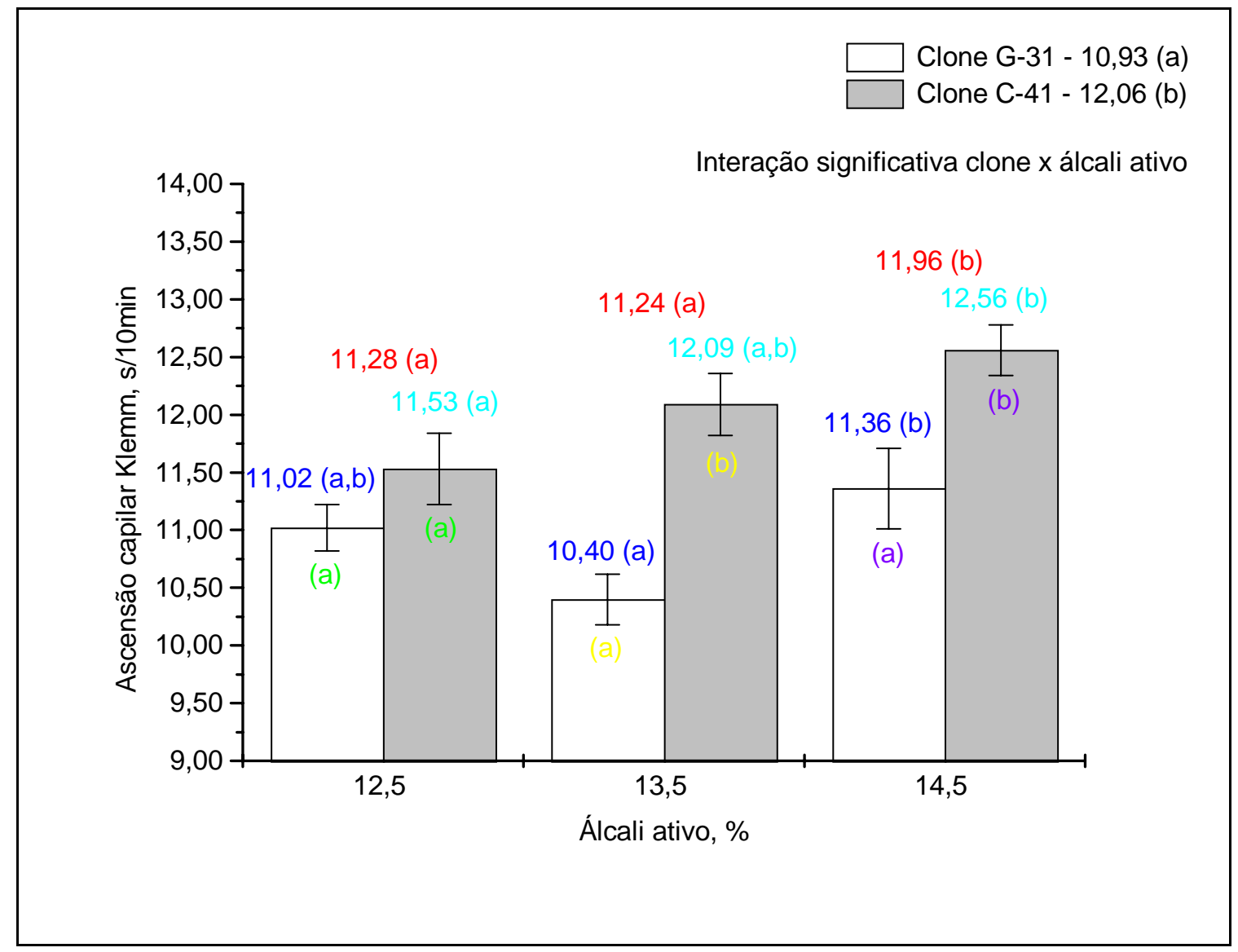

Figura 63 - Ascensão capilar Klemm da polpa sem refino

A ascensão capilar Klemm é um ensaio que mede a velocidade de absorção e muito importante para papel "tissue". A maior ascensão capilar Klemm para a polpa do clone C-41 em relação à polpa do clone G-31 pode ser atribuída a maior coarseness das fibras (fibras mais pesadas), a qual gera folhas com maior volume específico aparente da folha e com alta rapidez para absorver água. A elevação da ascensão capilar Klemm com a carga de álcali ativo pode ser explicada, também, pela elevação do volume específico aparente (ver Figura 53).

A Figura 64 mostra a opacidade da polpa sem refino. A análise de variância geral mostrou efeito significativo, em ordem decrescente, para clone e 
álcali ativo na opacidade. A análise de variância de álcali ativo dentro de clone foi significativa, somente, para o clone C-41. A análise de variância de clone dentro de álcali ativo foi significativa, somente, para 12,5\% de álcali ativo.

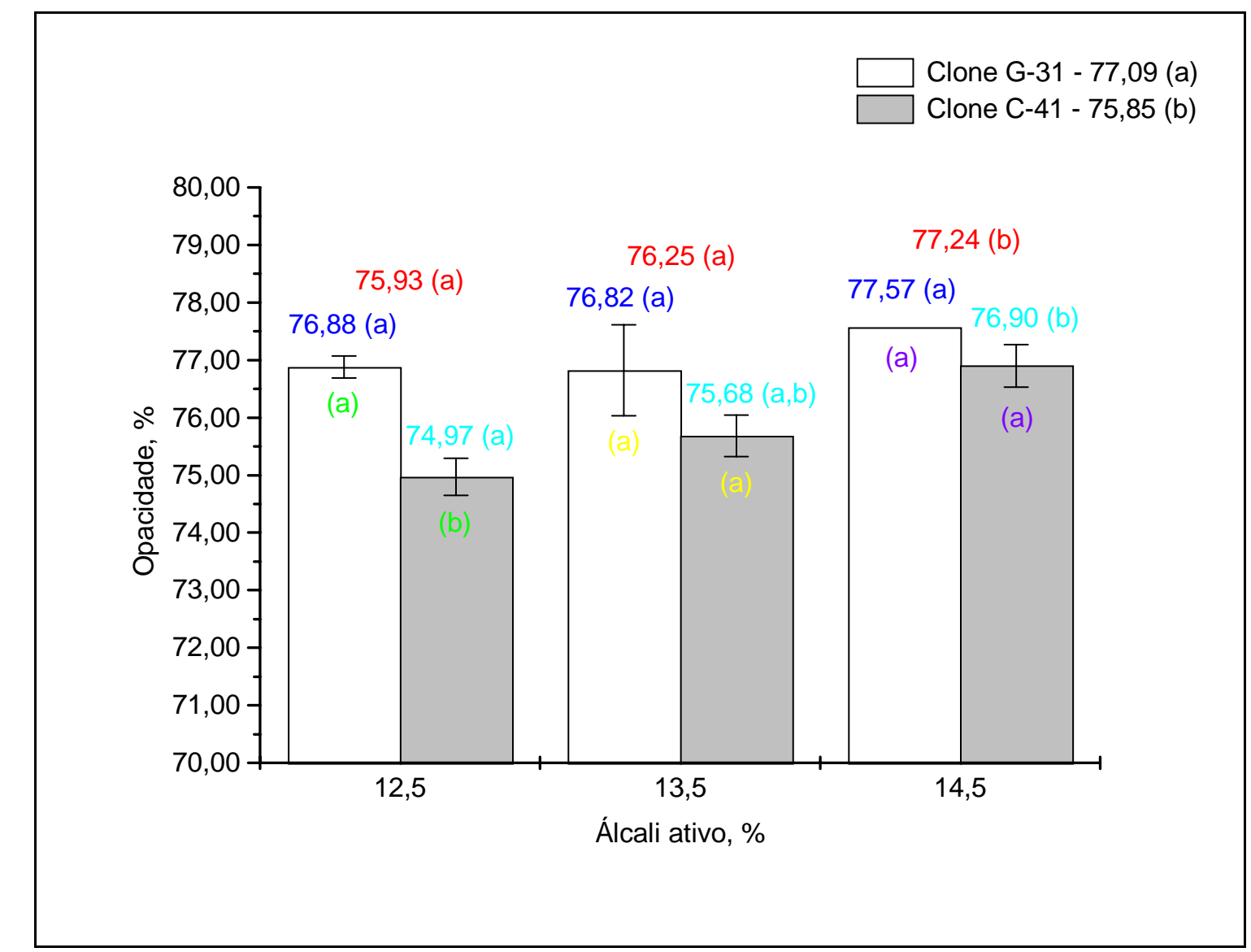

Figura 64 - Opacidade da polpa sem refino

Conforme mostra a Figura 64 através do Teste de Tukey, a análise de clone dentro de álcali ativo mostrou maior opacidade para a polpa do clone G-31 sendo significativo, somente, para $12,5 \%$ de álcali ativo. A análise de álcali ativo dentro de clone mostrou acréscimo da opacidade com a elevação da carga de álcali ativo, somente, para o clone C-41. Os fatores mais importantes na opacidade foram clone e álcali ativo. 
A maior opacidade para a polpa do clone G-31 em relação à polpa do clone C-41 pode ser atribuída a menor "coarseness" das fibras (fibras mais leves). A elevação da opacidade com a carga de álcali ativo pode ser explicada pela elevação do volume específico aparente (ver Figura 53). 


\section{CONCLUSÕES}

\section{a) Matéria-prima}

A madeira do clone G-31 caracterizou por apresentar, significativamente, menor densidade básica e teor de holocelulose, e maiores teores de extrativos totais e ligninas Klason total, insolúvel e solúvel em relação à madeira do clone C-41.

\section{b) Polpação Kraft}

A análise de clones dentro das cargas de álcali ativo mostrou rendimentos bruto e depurado semelhantes para os clones G-31 e C-41. A elevação da carga de álcali ativo dentro de clone revelou decréscimos significativos nestes rendimentos, sendo mais pronunciado para o clone G-31. O fator álcali ativo foi o mais importante nestes rendimentos.

O clone C-41 produziu polpas com maiores teores de rejeitos bases madeira e celulose, principalmente, nas menores cargas de álcali ativo. 0 aumento da carga de álcali ativo dentro de clone mostrou diminuição nos teores de rejeitos, sendo mais significativa para o clone C-41. Os fatores mais importantes nos teores de rejeitos, em ordem decrescente, foram álcali ativo e clone.

O clone G-31 produziu polpa com menor número kappa na menor carga alcalina e polpa com maior número kappa na maior carga alcalina revelando uma importante interação significativa clone $x$ álcali ativo. A elevação da carga 
de álcali ativo dentro de clone mostrou decréscimo mais acentuado do número kappa para o clone C-41. Os fatores mais significativos no número kappa, em ordem decrescente, foram álcali ativo, interação clone $\mathrm{x}$ álcali ativo e clone.

A análise de clone dentro de álcali ativo mostrou viscosidade intrínseca da celulose semelhante para os clones G-31 e C-41, exceto para 13,5\% de álcali ativo. A viscosidade da celulose decresceu de forma mais drástica para o clone G-31 quando da elevação da carga de álcali ativo dentro deste clone. Os fatores mais importantes para viscosidade da celulose, em ordem decrescente, foram álcali ativo e clone.

O clone G-31 necessitou de maior consumo específico de madeira que o clone C-41. O aumento da carga de álcali ativo dentro de clone mostrou elevação do consumo especifico de madeira somente para o clone G-31. Os fatores mais relevantes para consumo específico de madeira, em ordem decrescente, foram clone e álcali ativo.

\section{c) Licor residual da polpação Kraft}

A análise de clones dentro das cargas de álcali ativo mostrou valores de pH semelhantes para os clones G-31 e C-41. A elevação da carga de álcali ativo dentro de clone revelou aumento no $\mathrm{pH}$, sendo mais pronunciado para o clone C-41. O fator álcali ativo foi o mais importante no $\mathrm{pH}$.

O resultado de clones dentro das cargas de álcali ativo mostrou valores de teores de sólidos solúveis semelhantes para os clones G-31 e C-41. A elevação da carga de álcali ativo dentro de clone mostrou elevação no teor de sólidos solúveis, sendo mais significativo para o clone G-31. O fator que exerceu maior reflexo no teor de sólidos solúveis foi o álcali ativo.

A análise de clones dentro das cargas de álcali ativo mostrou densidades do licor residual semelhantes para os clones G-31 e C-41. A elevação da carga de álcali ativo dentro de clone mostrou aumento na densidade do licor residual, 
sendo mais significativo para o clone G-31. O fator que exerceu maior influência na densidade do licor residual foi o álcali ativo.

O resultado de clones dentro das cargas de álcali ativo mostrou valores de álcalis ativos residual semelhantes para os clones G-31 e C-41. A elevação da carga de álcali ativo dentro de clone mostrou elevação no álcali ativo residual, sendo mais significativo para o clone C-41. O fator que exerceu maior reflexo no teor de álcali ativo residual foi o álcali ativo.

Os resultados de clones dentro das cargas de álcali ativo mostraram valores de álcali efetivos e totais residual semelhantes para os clones G-31 e C41. A elevação da carga de álcali ativo dentro de clone mostrou elevação nos álcalis efetivo e total residual, sendo mais significativo para o clone G-31. O fator mais importante nos teores de álcalis efetivo e total foi o álcali ativo.

A análise de clones dentro das cargas de álcali ativo mostrou maior álcali ativo consumido base madeira para o clone G-31. A elevação da carga de álcali ativo dentro de clone mostrou menor álcali ativo consumido base madeira sendo mais significativo para o clone G-31. Os fatores que exerceram maiores influências no álcali ativo consumido base madeira, em ordem decrescente, foram clone, álcali ativo e interação clone $x$ álcali ativo.

A análise de clones dentro das cargas de álcali ativo mostrou maior álcali ativo consumido base produto químico para o clone G-31. A elevação da carga de álcali ativo dentro de clone mostrou menor álcali ativo consumido base produto químico, sendo mais significativo para o clone G-31. Os fatores que exerceram maiores influências no álcali ativo consumido base produto químico, em ordem decrescente, foram álcali ativo, clone e interação clone x álcali ativo.

\section{d) Branqueamento da polpa}

A análise de clones dentro das cargas de álcali ativo mostrou maior eficiência na pré-deslignificação com oxigênio para o clone G-31. A elevação da carga de álcali ativo dentro de clone reduziu a eficiência de deslignificação, 
sendo mais pronunciada para o clone C-41. Os fatores que exerceram maiores influências na pré-deslignificação, em ordem decrescente, foram álcali ativo, clone e interação clone $x$ álcali ativo.

O resultado de clones dentro das cargas de álcali ativo mostrou valores de número kappa após pré-deslignificação maiores para o clone C-41. A elevação da carga de álcali ativo dentro de clone mostrou redução do número kappa após pré-deslignificação, sendo mais significativo para o clone C-41. Os fatores que exerceram maiores reflexos no número kappa após prédeslignificação foram, em ordem decrescente, álcali ativo e clone.

Os números kappa das polpas dos clones G-31 e C-41 se igualaram após o estágio $\mathrm{E}_{\mathrm{OP}}$.

A análise de clones dentro das cargas de álcali ativo mostrou viscosidade intrínseca da celulose final maior para o clone C-41. A elevação da carga de álcali ativo dentro de clone mostrou diminuição da viscosidade intrínseca da celulose final, sendo mais significativo para o clone $\mathrm{C}-41$. Os fatores mais importantes para viscosidade da celulose final, em ordem decrescente, foram clone e álcali ativo.

A análise de clones dentro das cargas de álcali ativo mostrou que o clone G-31 produziu polpa com maior alvura final na menor carga alcalina e polpa com menor alvura final nas maiores cargas de álcali ativo revelando uma importante interação significativa clone $x$ álcali ativo. A elevação da carga de álcali ativo dentro de clone mostrou decréscimo da alvura final para o clone G-31 e elevação da alvura para o clone C-41. Os fatores que exerceram maiores influências na alvura final, em ordem decrescente, foram interação clone $x$ álcali ativo, clone e álcali ativo.

\section{e) Morfologia da fibra na polpa branqueada}

A fibra da polpa branqueada do clone G-31 apresentou, significativamente, maiores comprimento de fibra, espessura da parede, índice 
de enfeltramento, fração parede e índice de Runkel; e menores diâmetro do lume, coeficiente de flexibilidade e "coarseness". O menor valor de "coarseness" mostrou fibras mais leves na polpa do clone G-31.

A elevação da carga alcalina provocou pequenos decréscimos, mas significativos, na largura e diâmetro do lume da fibra e acréscimo no índice de enfeltramento. Este efeito foi mais pronunciado na análise dentro do clone C-41. O comprimento e a espessura da parede da fibra não alteraram com a elevação da carga alcalina.

\section{f) Qualidade da polpa branqueada}

O fator clone exerceu maior influência nas propriedades físicas e mecânicas da polpa branqueada, tanto em índice de tração constante e igual a $70 \mathrm{~N} . \mathrm{m} / \mathrm{g}$ quanto sem refino.

A polpa branqueada do clone G-31 apresentou, significativamente, menor número de revoluções no moinho PFI para atingir o índice de tração de 70 N.m/g, baixo grau Schopper Riegler para atingir este nível de tração e gerou folhas com valores mais elevados de volume específico e opacidade. Estas características e propriedades permitem concluir que a polpa do clone G-31 foi a mais atrativa e indicada para a fabricação de papéis de imprimir e escrever.

A polpa branqueada do clone C-41 se caracterizou por apresentar valores mais elevados de volume específico aparente e ascensão capilar Klemm quando analisadas sem refino. Estas propriedades foram mais evidentes nas cargas de álcali ativo mais elevadas. A polpa do clone C-41 mostrou características mais favoráveis para a fabricação de papéis para fins sanitários. 


\section{REFERÊNCIAS BIBLIOGRÁFICAS}

ALENCAR, G. S. B. Estudo da qualidade da madeira para produção de celulose relacionada à precocidade na seleção de híbrido $E$. grandis $\times$ E. urophylla. Piracicaba, 2002. 145p. Dissertação (Mestrado) - Escola Superior de Agricultura "Luiz de Queiroz". Universidade de São Paulo.

ALFENAS, A. C.; ZAUZA, E. A. V.; MAFIA, R. G.; ASSIS, T. F. Clonagem e doenças do eucalipto. Viçosa: UFV, 2004. 442p.

ALMEIDA, F. S. Influência da carga alcalina no processo de polpação Lo-Solids ${ }^{\circledR}$ para madeiras de eucalipto. Piracicaba, 2003. 115p. Dissertação (Mestrado) - Escola Superior de Agricultura "Luiz de Queiroz". Universidade de São Paulo.

ALMEIDA, J. M.; GOMIDE, J. L.; SILVA, D. J. Dissolução dos constituintes da madeira de eucalipto ao longo dos processos Kraft contínuo convencional e aditivado. Revista Árvore, v.24, n.2, p.215-222, 2000.

AMIDON, T.E. Effect of the wood properties of hardwoods on Kraft paper properties. Tappi Journal, v.64, n.3, p.123-126, Mar. 1981.

ASTALS, F.; COMA, I. Naturaleza, efectos y medida del refinado: Últimos avances en la tecnologia del refinado. UNIVERSIDAD POLITÉCNICA DE CATALUNA (ETSEIT), Ed. Terrassa, 1988, p.43-72

AXELSSON, P.; EK, M.; TEDER, A. Influence of the alkali profile in the Kraft cook on the bleachability of birch. (s.n.t.), p. 41-44. 
AXELSSON, P.; EK, M.; TEDER, A. The influence of temperature and alkali charge in the Kraft cook on the bleachability of birch. In: EUROPEN WORKSHOP ON LIGNOCELLULOSICS AND PULP, 6., Bordeaux, 2000. Proceedings Bordeaux: s.ed., 2000. p. 85-88.

BAMBER, R. K. The wood anatomy of eucalyptus and paper making. Appita Journal, v.38, n.3, p.210-216, 1985.

BARBOSA, F. E. V. The Eucalyptus fiber for printing \& writing papers. BRAZILIAN SYMPOSIUM ON THE CHEMISTRY OF LIGNIN AND OTHER WOOD COMPONENTS, 7., Belo Horizonte, 2001. Papers Belo Horizonte, s.ed., 2001. 2p.

BARZYC, D.; PAGE, D. H.; RAGAUSKAS, A. Carboxilic acid groups and fibre bonding. FUNDAMENTAL RESEARCH SYMPOSIUM, 11., Cambridge, 1997. Proceedings Cambridge: s.ed.,1997. p.893-907.

BERTOLUCCI, F.; REZENDE, G.;PENCHEL, R. Produção e utilização de híbridos de eucalipto. Silvicultura, v.13, n.51, p.12-18, 1993.

BRAATEN, K. R.; MOLTEBERG, D. A mathematical method for determining fiber wall thickness and fiber width. Tappi Journal, v.3, n.2, p.9-12, 2004.

BRINDLEY, C. L.; KIBBLEWHITE, R. P. Comparison of refining response of eucalypt and a mixed hardwood pulp and their blends with softwood. Appita Journal, v.49, n.1, p.37-42, 1996.

BUSNARDO, C. A. Estudos sobre a deslignificação da madeira de Eucalyptus urophylla de origem híbrida, pelo processo Kraft para a produção de celulose. Viçosa, 1981. 251p. Dissertação (Mestrado) - Universidade Federal de Viçosa. 
CARVALHO, A. M. Valorização da madeira do híbrido Eucalyptus grandis x Eucalyptus urophylla através da produção conjunta de madeira serrada em pequenas dimensões, celulose e lenha. Piracicaba, 2000. 129p. Dissertação (Mestrado) - Escola Superior de Agricultura "Luiz de Queiroz". Universidade de São Paulo.

CARVALHO, H. G.; OLIVEIRA, R.C.; GOMIDE, J. L.; COLODETTE, J. L. Efeito da idade de corte da madeira e de variáveis de refino nas propriedades da celulose Kraft branqueada de eucalipto. In: CONGRESSO ANUAL DE CELULOSE E PAPEL DA ABTCP, 31., São Paulo, 1998. Anais São Paulo: ABTCP, 1998. p.367-381.

CARVALHO, M. G.; FERREIRA, P. J.; MARTINS, A. A.; FIGUEIREDO, M. M. A comparative study of two automated techniques for measuring fiber length. Tappi Journal, v.80, n.2, p. 137-142, 1997.

CASALS, R. Características del papel. Barcelona: Howson - Algraphy, s.d..174p.

CLARK, J. d'A. Pulp technology and treatment for paper. $2^{a}$ ed., San Francisco: Miller Freeman Publications, 1985.

COLLINS, D. J.; PILOTTI, C. A.; WALLIS, A. F. A. Correlation of chemical composition and Kraft pulping properties of some Papua New Guinea reforestation woods. Appita Journal, v.43, n.3, p.193-198, 1990.

COTTERILL, P.; MACRAE, S. Improving eucalyptus pulp and paper quality using genetic selection and good organization. Tappi Journal, v.80, n.6, p. 82-89, 1997.

DEMUNER, B. J.; MANFREDI, V.; CLÁUDIO-DA-SILVA JÚNIOR, E. Refino de celulose de eucalipto: uma análise fundamental. O Papel, v.51, n.8, p.44-54, 1990. 
DEMUNER, B. J.; VIANNA DORIA, E. L.; CLAUDIO-DA-SILVA JÚNIOR, E.; MANFREDI, V. As propriedades do papel e as características das fibras de Eucalipto. In: CONGRESSO ANUAL DE CELULOSE E PAPEL DA ABTCP. São Paulo, 1991. Anais São Paulo: ABTCP, 1991. p. 621-641.

DILLNER, B.; JONSSON, P. A classification of hardwood pulps for paper, in New pulps for the paper industry. HAAS, L. E. San Francisco: Miller Freeman Publications, 1979. p. 25-35.

DINUS, R. J.; WELT, T. Tailoring fiber properties to paper manufacture: Recent developments. Tappi Journal, v.80, n.4, p.127-139, 1997.

DINWOODIE, J.M. The relationship between fiber morphology and paper properties: A review of literature. Tappi Journal, v.48, n.8, p.440-447, Aug. 1965.

DUFFY, G. G.; KIBBLEWHITE, R. P. A new method of relating wood density, pulp quality and paper properties. Appita Journal, v.42, n.3, p.209-214, 1989.

EK, M.; GUSTAVSSON, C.; KADIRIC, J.; TEDER, A. Formation and dissolution/degradation of hexenuronic acids during Kraft pulping of Eucalyptus globulus. In: BRAZILIAN SYMPSIUM ON THE CHEMISTRY OF LIGNIN AND OTHER WOOD COMPONENTS. 7, Belo Horizonte, 2001. Proceedings Belo Horizonte: UFV, 2001. p.99-106.

FAO. Global forest resources assessment 2000 - Main report. FAO Forestry Paper. ISSN 0258-6150, $2000 . \quad 479 p$. www.fao.org/forestry/fo/fra/main/index.jsp. 2000.

FARDIM, P.; DURÁN, N. Retention of cellulose, xylan and lignin in Kraft pulping of Eucalyptus studied by multivariate data analysis: Influences on physicochemical and mechanical properties of pulp. Journal of the Brazilian Chemical Society, v.15, n.4, p.514-522, 2004. 
FERREIRA, A. D.; MENDES DE SOUSA, A. P. Índice de qualidade para pastas Kraft de fibra curta demonstra superioridade da pasta de Eucalyptus globulus. Pasta e Papel, s.d.

FERREIRA, P.J.; FIGUEIREDO, M.M. Efeito do cozimento e da refinação nas dimensões transversais de fibras de E. globulus. O Papel, v.62, n.1, p.73-80, jan. 2001.

FERREIRA, P. J.; CARVALHO, M. G.; MARTINS, A. A.; FIGUEIREDO, M. M. Efeito das variáveis de cozimento Kraft na refinação de pastas de E. globulus nacional - Avaliação das propriedades papeleiras. In: CONFERÊNCIA INTERNACIONAL DE ENGENHARIA QUÍMICA, 7., Lisboa, Pt., 1998. Anais Lisboa: s.ed., 1998. p.353-360.

FOELKEL, C. E. B. Rendimentos em celulose sulfato de Eucalyptus spp em função do grau de deslignificação e da densidade da madeira. Revista IPEF, n. 9, p. 61-77, 1974.

FOELKEL, C. E. B. Eucalyptus wood and pulp quality requirements oriented to the manufacture of tissue and printing \& writing paper. APPITA ANNUAL GENERAL CONFERENCE, 52., Brisbane, Austrália, 1998. Anais Brisbane: s.ed., 1998. v.1. 5p.

FOELKEL, C. E. B.; BRASIL, M. A. M.; BARRICHELO, L. E. G. Métodos de determinação da densidade básica de cavacos para coníferas e folhosas. IPEF, n.2/3, p.65-74, 1971.

FOELKEL, C.E.B.; BARRICHELO, L.E.G. Relações entre características da madeira e propriedades da celulose e papel. In: CONGRESSO ANUAL DA ABTCP - Semana do Papel, 8. São Paulo, 1975. Anais São Paulo: ABTCP, 1975. p.40-53. 
FOELKEL, C. E. B.; MORA, E.; MENOCHELLI, S. Densidade básica: sua verdadeira utilidade como índice de qualidade da madeira de eucalipto para produção de celulose. O Papel, p. 35-40, maio-1992.

GENGO, J. M.; BUSAYASAKUL, N.; MEDHORA, H. K. et al. Hemicellulose retention during Kraft pulping. Tappi Journal, v.73, n.4, p.223-233, 1990.

GOMIDE, J. L. Polpa celulósica: química dos processos alcalinos de polpação. Viçosa: UFV, 1979. 50p.

GOMIDE, J. L.; COLODETTE, J. L.; OlIVEIRA, R. C.; GIRARD, R.; ARGYROPOULOS, D. S. Fatores que afetam a branqueabilidade de polpas Kraft de Eucalyptus. 2: Influência de parâmetros da polpação. In: CONGRESSO INTERNACIONAL DE CELULOSE E PAPEL - ABTCP, São Paulo, 2000. Anais São Paulo: ABTCP, 2000. p.1-9.

GONÇALEZ, J. C.; GOMIDE, J. L.; VITAL, B. R. Estudos tecnológicos da madeira de brotações de Eucalyptus grandis para produção de celulose Kraft. Revista Árvore, v.10, n.1, p.1-15, 1986.

HATTON, J. V.; COOK, J. Kraft pulps from second growth Douglas-fir: relationships between wood, fiber, pulp and handsheet properties. Tappi Journal, v.75, n.1, p.137-144, 1992.

IKEMORI, Y. K.; CAMPINHOS JÚNIOR., E. Produção de sementes de Eucalyptus grandis x Eucalyptus urophylla por polinização aberta: resultados preliminares. Silvicultura, v.8, n.28, p.306-308, 1983.

ITO, M. H. A refinação de fibra de eucalipto. O Papel, v.38, n.12, p.99-113, 1977. 
JORDÃO, M. C. S.; MANGOLINI, N. J. Avaliação de pastas ligno-celulósicas para fins absorventes com ênfase em pasta fofa (fluff pulp). In: CONGRESSO ANUAL DE CELULOSE E PAPEL DA ABTCP, 21., São Paulo, 1988. Anais São Paulo: ABTCP, 1988. p. 295-309.

KEREKES, R. J.; SCHELL, C. J. Effects of fiber length and coarseness on pulp flocculation. Tappi Journal, v.78, n.2, p.133-139, 1995.

KOLLMAN, F. Tecnología de la madera y sus aplicaciones. Madrid: Instituto Forestal de Investigaciones y Experiencias y Servicios de la Madera, 1959. p.359-394.

LAINE, J.; HYNYNEN, R. The effect of surface chemical composition and charge on the fiber and paper properties of unbleached Kraft pulps. In: FUNDAMENTAL RESEARCH SYMPOSIUM, 11., Cambridge, 1997. Anais Cambridge: s.ed., 1997. p.859-891.

LEVLIN, J. E.; SÖDERHJELM, L. Pulp and paper testing. Atlanta: Tappi Press, 1999. v.17, 288 p. 1999. (Papermaking Science and Technology Series).

LIU, J.; HSIEH, J. Caracterização da maciez em papel tissue facial. O Papel/Tappi Journal, v.4, n.2, p.22-30, 2004. Número especial.

MALONEY, T. C.; LAINE, J. E.; PAULAPURO, H. Comments on the measurement of cell wall water. Tappi Journal, v.82, n.9, p. 125-127, 1999.

MOKFIENSKI, A.; GOMIDE, J.L., COLODETTE, J.L.; OLIVEIRA, R.C. Importância da densidade e do teor de carboidratos totais da madeira de eucalipto no desempenho da linha de fibra. In: COLÓQUIO INTERNACIONAL SOBRE CELULOSE KRAFT DE EUCALIPTO. Viçosa: set. 2003. p.15-38. 
ODA, S.; FERREIRA, M. Produção de híbridos interespecíficos de eucalipto por polinização aberta. In: CONGRESSO FLORESTAL BRASILEIRO, 4, Belo Horizonte/MG, 1982. Silvicultura, n.28, p.407-408, 1982.

OLIVEIRA, R.L. A influência da madeira na branqueabilidade e estabilidade de alvura de polpas Kraft de eucalipto. Viçosa, 2004. 95p. Dissertação (Mestrado) - Universidade Federal de Viçosa.

PAAVILAINEN, L. Effect of sulfate cooking parameters on the papermaking potential of pulp fibres. Paperi ja Puu - Paper and Timber, v.71, n.4, p.356363, 1989.

PAAVILAINEN, L. Importance of cross-dimensional fibre properties and coarseness for the characterization of softwood sulfate pulp. Paperi ja Puu Paper and Timber, v.75, n.5, p.343-351, 1993.

PAAVILAINEN, L. Quality competitiveness of Asian short-fibre raw materials in different paper grades. Paperi ja Puu - Paper and Timber, v. 82, n. 3, p.156-161, 2000.

PAScoAl Neto, C.; EVtuguin, D. V.; DANIEL, A. I. D.; SIVESTRE, A.; FURTADO, F. P.; MENDES SOUSA, P. ECF bleaching response of Eucalyptus globulus Kraft pulps: Influence of pulping conditions and relationship with chemical structure of pulps. EUCEPA CONFERENCE SUSTAINABLE DEVELOPMENT FOR THE PULP AND PAPER INDUSTRY, 28., Lisbon, Pt., 2003. Anais Lisbon: s.ed., 2003, p.35-40.

PAULAPURO, H. Paper and board grades. Atlanta: 2000. 134p. (Papermaking Science and Technology Series).

PIRES, I. E.; PAULA, R. C. De estado da arte de melhoramento genético para qualidade da madeira de eucalipto: uma revisão. In: IUFRO CONFERENCE ON SILVICULTURE AND IMPROVEMENT OF EUCALYPTS. Salvador, 1997. Anais Colombo: EMBRAPA/CNPF, 1997. v.3, p.186-191. 
RATNIEKS, E.; FOELKEL, C. E. B. Uma discussão teórico-prática sobre polpas de eucalipto para a fabricação de papel "Tissue". In: CONGRESSO ANUAL DE CELUlose E PAPEL DA ABTCP, 29., São Paulo, 1996. Anais São Paulo: ABTCP, 1996. p.18.

ROBERTSON, G.; OLSON, J.; ALLEN, P.; CHAN, B.; SETH, R. Measurement of fiber length, coarseness, and shape with the fiber quality analyzer. Tappi Journal, v.82, n. 10, p. 93-99, 1999.

RUY, O. F. Variação da qualidade da madeira em clones de Eucalyptus urophylla S. T. Blake da llha de Flores, Indonésia. Piracicaba, 1998. 69p. Dissertação (Mestrado) - Escola Superior de Agricultura "Luiz de Queiroz", Universidade de São Paulo.

SALVADOR, E.; COLODETTE, J. L.;GOMIDE, J. L.; OLIVEIRA, R. C. Efeito da deslignificação com oxigênio nas propriedades físico-mecânicas de polpas Kraft. O Papel, v. 62, n. 2, p. 75-96, 2001.

SANTOS, C. R. Métodos não-convencionais para determinação de celulose como parâmetro de seleção de árvores matrizes visando a produção de polpa Kraft-AQ. Piracicaba, 2000. 117p. Dissertação (Mestrado) - Escola Superior de Agricultura “Luiz de Queiroz", Universidade de São Paulo.

SETH, R. S.; CHAN, B. K. Measurement of fiber coarseness with optical fiber length analyzers. Tappi Journal, v. 80, n.5, p.217-221, 1997.

SILVA, D. J. Impacto da qualidade da madeira na deslignificação, no branqueamento e nas propriedades físico-mecânicas da polpa Kraft de Eucalipto. Viçosa, 1996. 103p. Dissertação (Mestrado) - Departamento de Engenharia Florestal, Universidade Federal de Viçosa.

SILVA, D. J.; OLIVEIRA, R. C.; COLODETTE, J. L.; GOMIDE, J. L. Impacto da qualidade da madeira na deslignificação, no branqueamento e na qualidade da polpa Kraft de clones de eucalipto. O Papel, v.58, n. 2, p.33-43, 1997. 
SILVA JÚNIOR, F. G.; VALLE, C. F.; MUNER, J. C. G. Programa de qualidade da madeira da Votorantim Celulose e Papel - VCP. O Papel, n.1, v. 57, p.35-43, 1996.

SPIEGELBERG, H. L. The effect of hemicellulose on the mechanical properties of individual pulp fibres. Tappi Journal, v.49, n.9, p.388, 1966.

TECHNICAL ASSOCIATION OF THE AMERICAN PULP AND PAPER INDUSTRY - TAPPI. Test methods. Atlanta: TAPPI, 1994. 1v.

TREPANIER, R. J. Automatic fiber length and shape measurement by image analysis. Tappi Journal, v.81, n.6, p. 152-154, 1998.

VAlente, C. A.; MENDES DE SOUSA, A. P.; FURTADO, F. P.; CARVALho, A. P. Improvement program for Eucalyptus globulus at Portucel: Technological component. Appita Journal, v.45, n.6, p.403-407, 1992.

VASCONCELOS DIAS, R.L.; CLAUDIO-DA-SILVA JÚNIOR, E. A influência da densidade básica da madeira de híbridos de Eucalyptus grandis em suas características químicas, e propriedades de polpação e do papel. In. CONGRESSO ANUAL DA ABTCP - Semana do Papel,18., São Paulo, 1985. Anais São Paulo: ABTCP, 1985. p.31-55.

WAGBERG, L.; ANNERGREN, G. Physicochemical characterization of papermaking fibres. In: FUNDAMENTAL RESEARCH SYMPOSIUM, 11., Cambridge, 1997. Anais Cambridge: s. ed., 1997. p.1-82.

WALLIS, A. F. A.; WEARNE, R. H., WRIGHT, P. J. Analytical characteristics of plantation eucalypt woods relating to Kraft pulp yields. Appita Journal, v.49, n.6, p.427-432, 1996a.

WALLIS, A. F. A.; WEARNE, R. H., WRIGHT, P. J. Chemical analysis of polysaccharides in plantation eucalypt woods and pulps. Appita Journal, v.49, n.4, p.258-262, 1996 b. 
WEHR, T. F. A. Variações nas características da madeira de E. grandis Hill ex maiden e suas influências na qualidade de cavacos em cozimento Kraft. Piracicaba, 1991. 84p. Dissertação (Mestrado) - Escola Superior de Agricultura "Luiz de Queiroz", Universidade de São Paulo.

WRIGHT, P. J.; WALLIS, A. F. A. Rapid determination of cellulose in plantation eucalypt woods to predict Kraft pulp yields. Tappi Journal, v.81, n.2, 1998. 